\title{
Бенедикт Андерсои
}

\section{Уявлені спільноти}

Міркування щодо походження й поширення націоналізму

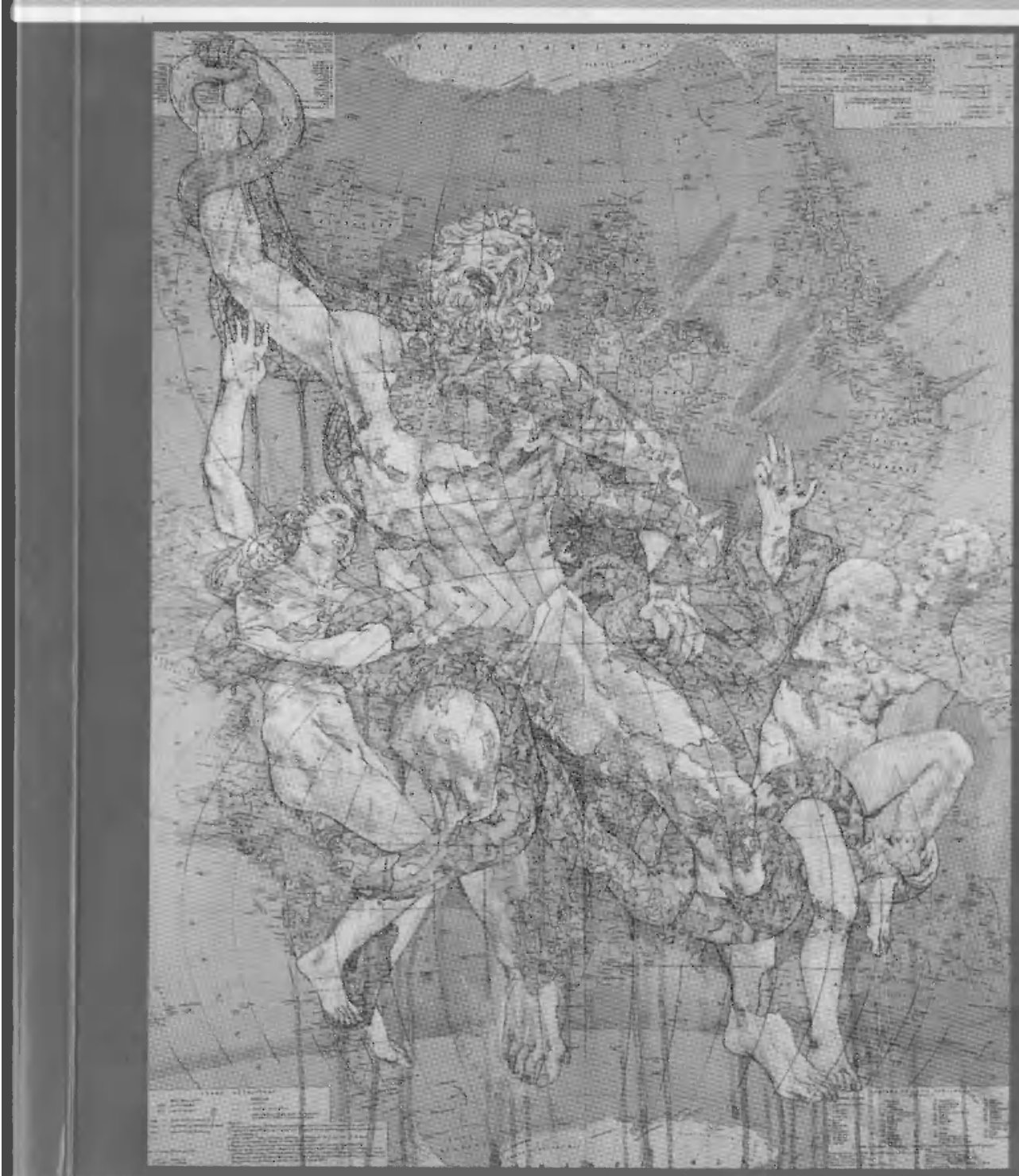

- КРИТИКА • 


$$
L
$$


Бенедикт Андерсон

Уявлені спільноти 
Benedict Anderson

\title{
Imagined Communities
}

Reflections on the Origin and Spread of Nationalism

\author{
Revised Edition
}

VER S O

London • New York 
Бенедикт Андерсон

\section{Уявлені спільноти}

Міркування щодо походження

й поширення націоналізму

Друге, перероблене видання

- КРИТИКА •

Київ 2001 
Класична, перекладена багатьма мовами праця американського вченого дає напрочуд оригінальну й водночас переконливу інтерпретацію непростих процесів зародження й формування новочасної національної свідомості в ранньомодерних суспільствах.

Перекладено за виданням:

Benedict Anderson

Imagined CommunitiesReflections on the Origin and Spread of Nationalism

Revised Edition

Перше видання Verso 1983

Переклад з англійської Віктора Морозова

Видання побачило світ завдяки фінансовій підтримці

Міжнародного фонду "Відродження" та

Public Affairs Section of US Embassy (Ukraine)

ISBN 966-7679-16-0

(C) Benedict Anderson, 1983, 1991

(C) «Критика», переклад, макет та художнє оформлення, 2001 


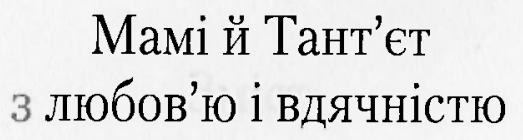




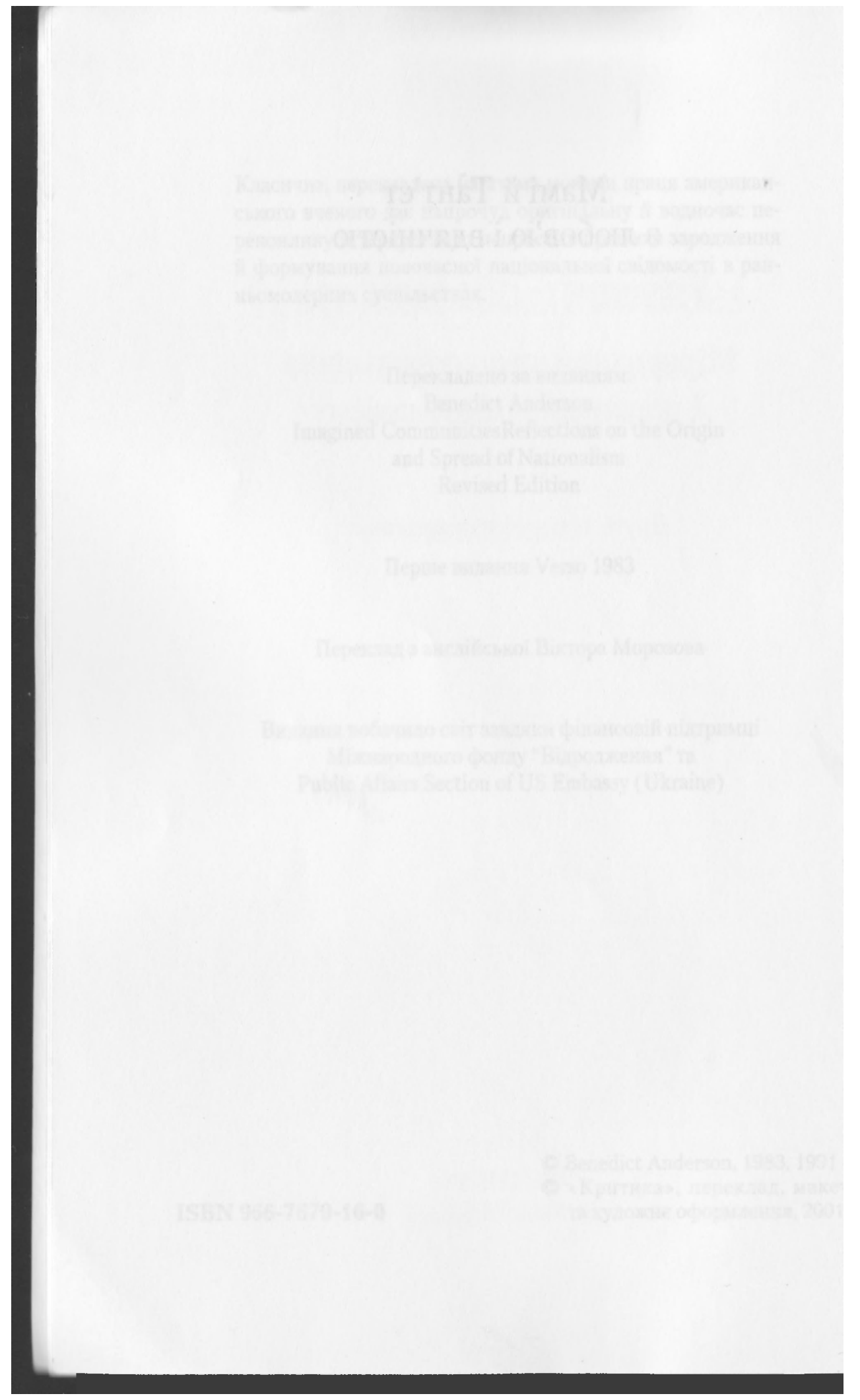




\section{Змicт}

Передмова до другого видання

1 Вступ

2 Культурні корені

3 Витоки національної свідомості

4 Креольські першовідкривачі

5 Старі мови, нові моделі

6 Офіційний націоналізм та імперіалізм 109

7 Остання хвиля 143

8 Патріотизм і расизм 177

9 Ангел Історії 193

10 Перепис, карта, музей 203

11 Пам'ять і забуття 231

Бібліографія 253

Покажчик 


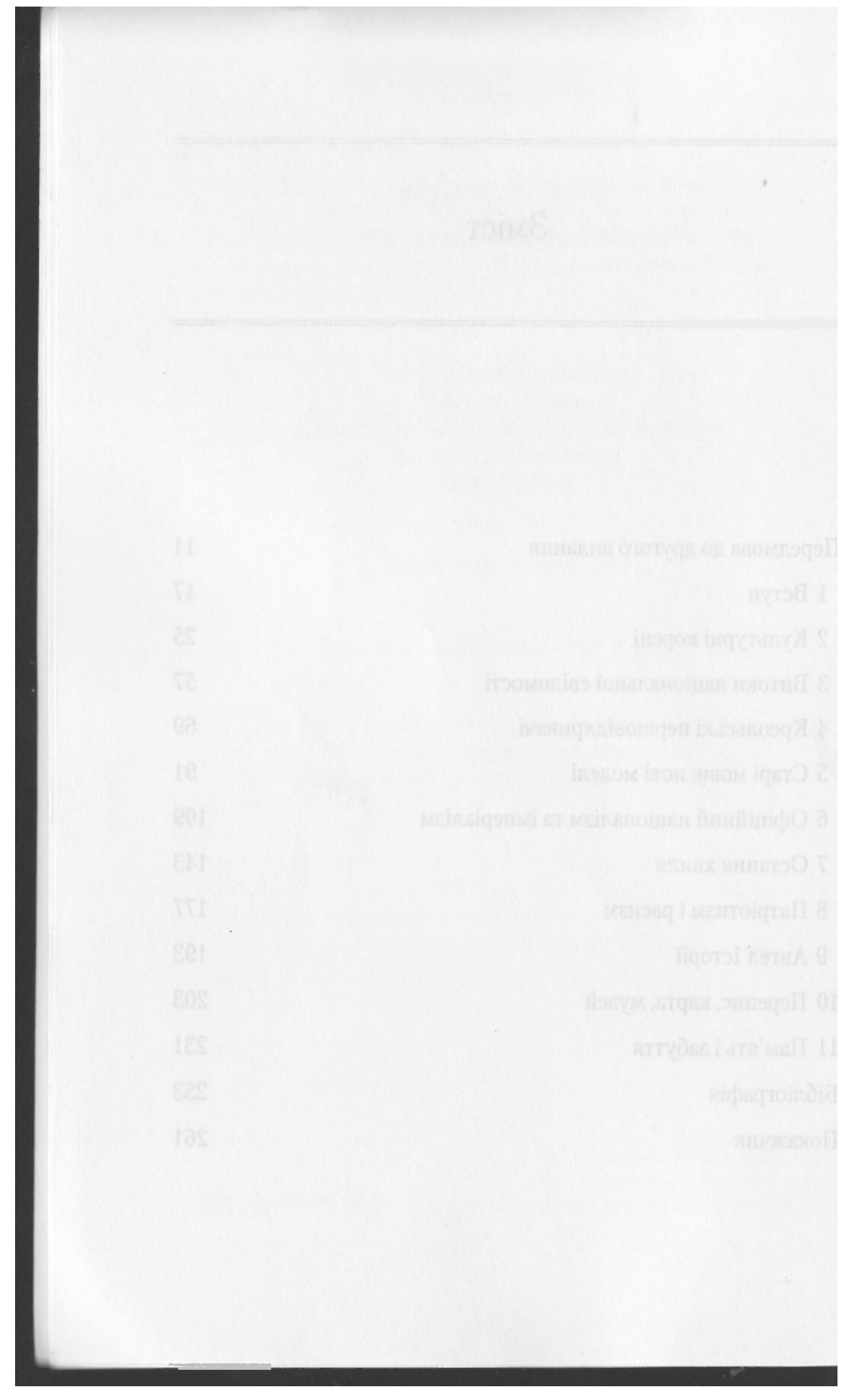




\section{Подяка}

Як пересвідчиться читач, глибокий вплив на мої роздуми 3 приводу націоналізму справили праці Еріха Ауербаха, Волтера Бенджаміна й Віктора Тернера. В роботі над самою книгою я вельми скористався з критики й порад мого брата Перрі Андерсона, Ентоні Бернетта і Стіва Гедера. Неоціненпу допомогу мені також надавали різним чином Д. А. Беллерд, Могамед Чамбас, Пітер Каценштейн, покійний Рекс Мортімер, Френсіс Мулерн, Том Нейрн, Шіраіші Такаші, Джім Сігел, Лора Саммерс і Еста Унгар. Звичайно, ніхто з цих доброзичливих критиків не несе жодної відповідальності за недоліки книги, які є повністю на моєму сумлінні. Можливо, варто додати, що я, за своєю освітою й фахом, фахівець 3 Південно-Східної Азії. Це зізнання допоможе пояснити деякі з упереджень книги та вибору прикладів, а також знизити їі можливі глобальні претензії. 
Своїм завданням він вважає погладжування історії проти шерсті.

\section{Волтер Бенджамін,} "Осяяння"

Ось так, із суміші нестямної постала Англійия розмаїтая постава:

Із гвалту й пристрасті народжений гібрид, Сплелися в ньому скотт і бритm:

Їх чадо вчилось кланятись - воно

Впряглось швиденько в римськеє ярмо:

Відтоді напівкровки вже пішли,

Без мови, імені, покірні, як воли.

Щоб розігріти захололі вени знов,

Додали в суміш саксів й данів кров.

Батьків отих пихаті дочки і сини

Країни мають вже і нації свої,

Але й вони зізнатись мусять неохоче,

Що в них англійська чиста кров клекоче...

Деніел Дефо, уривок зі "Справжнього англійця" 


\section{Передмова до другого видання}

Хто б міг подумати, що чим далі від раю, тим грізніше бушуватиме буря?

Збройні конфлікти в Індокитаї 1978-1979 рр., які були безпосереднім поштовхом до написання першого варіанту "Уявлених спільнот", тепер, коли минуло всього лише двападцять років, належать нібито до іншої ери. Тоді мене переслідувала перспектива майбутніх повномасштабних воєн між соціалістичними державами. Нині половина з них лежить уламками біля ангельських стін, а решта з острахом очікує подібної ж долі. Війни, які чекають на вцілілих - це громадянські війни. Велика ймовірність, що на початку нового тисячоліття майже нічого не залишиться від Союзу Радянських Соціалістичних Республік, крім... власне республік.

Чи можливо було це якось передбачити? 1983 року я писав, що Радянський Союз був “тією ж мірою спадкоємцем донаціональних династичних держав, що й предтечею нового наднаціонального порядку двадцять першого століття". Але, проаналізувавши національні вибухи, що зруйнували величезні багатомовні й поліетнічні утворення, керовані з Відня, Лондона, Константинополя, Парижа й Мадрида, я не врахував, що ланцюг цих подій сягне, як мінімум, Москви. Можна себе меланхолійно втішати хіба тим, що історія, схо- 
же, діяла за "логікою” "Уявлених спільнот" ще краще, ніж це вдалось автору.

Не тільки світ змінився за дванадцять років. Дослідження націоналізму також зазнало дивовижної трансформації - в методі, масштабі, довершеності й загальній кількості праць. Тільки англійською мовою з'явилися "Нації перед націоналізмом" Д. А. Армстронга (1982), "Націоналізм і держава" Джона Брейлі (1982), "Нації й націоналізм" Ернеста Геллнера (1983), “Соціальні передумови національного відродження в Європі” Мирослава Гроха (1985), “Етнічне походження націй” Ентоні Сміта (1986), "Націоналістична думка й колоніальний світ" П. Четтерджі (1986) та "Нації й націоналізм після 1788 р." Еріка Хобсбоума (1990) - і це лише деякі з ключових текстів. Ці праці- своїм історичним розмахом та теоретичною потужністю - змусили традиційну літературу на цю тему виглядати застаріло. Частково ці праці сприяли появі величезної кількості історичних, літературних, антропологічних, соціологічних, феміністичних та інших досліджень, які пов'язують предмети своїх зацікавлень з націоналізмом і нацією .

Адаптувати текст "Уявлених спільнот" до вимог, породжених цими величезними змінами у світі й текстах - завдання вище моїх нинішніх сил. Краще, мабуть, залишити його в основному “нереставрованим" відбитком часу, із своєрідним стилем, силуетом і настроєм. Мене втішають дві речі. 3 одного боку, повна і остаточна розв'язка подій у старому соціалістичному світі залишається оповитою пітьмою невідомості. 3 іншого боку, своєрідний метод і зацікавлення "Уявлених спільнот”, на мою думку, усе ще лишаються на узбіччі новітніх досліджень націоналізму - і принаймні в цьому сенсі все ще не перевершені.

У цьому виданні я просто намагався виправити фактичні, концептуальні й інтерпретаційні помилки, яких я мусив би

${ }^{1} 3$ цього науково-дослідницького вибуху Хобсбоум наважився зробити висновок про наближення кінця ери націоналізму: сова Мінерви літає в сутінках. 
уникнути при підготовці оригінального варіанту. Ці иравки - в дусі, так би мовити, 1983 р. - включають деякі зміни тексту першого видання, а також два нових розділи, які, фактично, є скромними додатками.

В основному тексті я виявив дві серйозні помилки у ıерекладах, щонайменше одну невиконану обіцянку та один хибний акцент. Не маючи змоги читати іспанською 1983 року, я необачно довірився Леонові М. Гверреро та його перекладові на англійську мову "Noli Me Tangere" Хосе Рісаля, хоч існували й раніші переклади. Лише в 1990 р. я виявив, шаскільки дивовижно зіпсованою була версія Гверреро. Також, наводячи довгу й важливу цитату з праці Отто Бауера "Die Nationalitatenfrage und die Sozialdemokratie", я легковажно скористався перекладом Оскара Ясі. Недавня звірка :3 німецьким оригіналом показала мені, як сильно вплинули політичні уподобання Ясі на інтерпретацію тексту. Прииаймні у двох місцях я віроломно пообіцяв з'ясувати, чому розвиток націоналізму в Бразилії відбувався так своєрідно ii запізніло порівняно з іншими південноамериканськими країнами. В новому виданні я намагаюсь виконати нарешті ту обіцянку.

Частиною мого первісного плану було підкреслити факт ıоходження націіоналізму з Нового світу. Я відчував, що неусвідомлений провінціалізм довгий час спотворював й перекручував теоретизування на цю тему. Європейські вчені, звиклі, що все суттєве в сучасному світі може походити тільки з Європи, надто легко брали за основу своїх моделей етнолінгвістичний націоналізм “другого покоління" (угорський, 'еський, грецький, польський тощо), незалежно від того, чи були вони “прихильниками", чи "опонентами" націоналізму. Мене вразило те, що, судячи з більшості відгуків на "Уявлені спільноти", цей євроцентричний провінціалізм залишився майже непорушним, а ключовий розділ книги про похоцження націоналізму в обох Америках був, як правило, зігнорований. На жаль, я не знайшов нічого кращого для "негайного" вирішення цієї проблеми, ніж дати нову назву четвертому розділу: “Креольські першовідкривачі”. 


\section{УяВЛЕНІ СПІЛЬНОТИ}

У двох “додатках" я намагаюся виправити серйозні теоретичні похибки першого видання ${ }^{2}$. Ряд доброзичливих критиків вважали, що в VII розділі (“Остання хвиля") надто спрощувався процес, за яким було змодельовано ранній націоналізм у "третьому світі". До того ж, у цьому розділі не було серйозно проаналізовано ту роль, яку, на відміну від метрополій, відігравали у становленні такого націоналізму локальні колоніальні держави. Водночас я збентежено усвідомив, що істотно новому, на мою думку, внескові в теорію націоналізму - мінливим концепціям часу - явно бракувало необхідної їм координати: мінливих концепцій простору. Блискуча докторська дисертація молодого таїландського історика Тхонгчай Вінічакула послужила мені стимулом для роздумів про вплив картографії на націоналістичну уяву.

Таким чином, розділ "Перепис, карта, музей" присвячений аналізові того, як, цілком несвідомо, колоніальна держава дев'ятнадцятого сторіччя (і політика, котру заохочувало ї̈ світобачення) діалектично сприяла виникненню граматики націоналізмів, які врешті-решт піднялися на боротьбу проти неї. Справді, можна навіть стверджувати, що держава, немов у зловісно-пророчому сні, виобразила своїх супротивників задовго до того, як ті історично почали існувати. Свій спільний внесок у формування такого уявлення зробили і переписи 3 їх абстрактною квантифікацією-серіалізацією індивідів, і карта з їі називанням політичного простору, і музей із його "екуменічною", світською генеалогізацією.

Поява другого "додатка" була викликана принизливим усвідомленням того, що 1983 року я цитував Ренана, зовсім не розуміючи змісту його слів: я сприйняв за легку іронію те, що насправді було цілковито абсурдним. Приниження змусило мене також визнати, що я не запропонував тоді

\footnotetext{
${ }^{2}$ Перший додаток походить із доповіді, підготовленої для конференції, шо відбувалася в Карачі в січні 1989 р., спонсорованої Світовим Інститутом Розвитку Економічних Досліджень при університеті ООН. Начерк другого додатка з'явився у “The Times Literary Supplement" 13 січня 1986 р. під рубрикою “Розповіді про націю.”
} 


\section{ПЕРЕДМОВА ДО ДРУГОГО ВИДАННЯ}

'іткого пояснення, як саме й чому новонароджені нації уяви.111 себе стародавніми. Те, що в більшості наукових праць витлумачувалось як макіавеллівський фокус-покус, чи буржуазна фантазія, чи викопна історична правда, раптом врази.1) мене як щось значно глибше й цікавіше. А що, коли та "стародавність", за певних історичних обставин, є неминучим "лслідком "новизни"? Якщо націоналізм був, як я гадаю, иисловом радикально нової форми свідомості, чи не мусить услідомлення цього розриву й неминуча втрата старої свідомості витворювати свій власний, новий наратив? Під таким кутом зору атавістичне фантазування, характерне для націоиалістичної думки після 1820 -х років, виглядає епіфеноме॥ом; справді істотним є структурне узгодження націоналіс'тиної “пам'яті" цього періоду з внутрішніми посилками й умовностями новочасної біографії й автобіографії.

Крім усіх теоретичних достоїнств і недоліків цих двох “додатків", кожен із них має ще й власні, більш банальні обмеження. Дані для розділу "Перепис, карта, музей” було зібрано виключно на матеріалі Південно-Східної Азії. У певпому відношенні цей регіон надає чудовий матеріал для порівняльного теоретизування, адже до нього входять як колишні колонії майже всіх великих імперій (Англії, Франції, Голландії, Португалії, Іспанії та СІША), так і неколонізоњаний Сіам. І все ж, майбутнє покаже, чи мій аналіз, за всієї ііого вірогідності щодо саме цього регіону, може бути достатньо переконливо застосований і щодо інших частин світу. Що ж до другого додатка, то поданий там розрізнений емпіричний матеріал майже виключно стосується Західної Свропи й Нового світу, тобто регіонів, з якими я досить поиерхово обізнаний. Але увага мусила бути спрямована туди, оскільки саме там вперше заговорили про перехід націоналізму до небуття.

Лютий 1991

Бенедикт Андерсон 


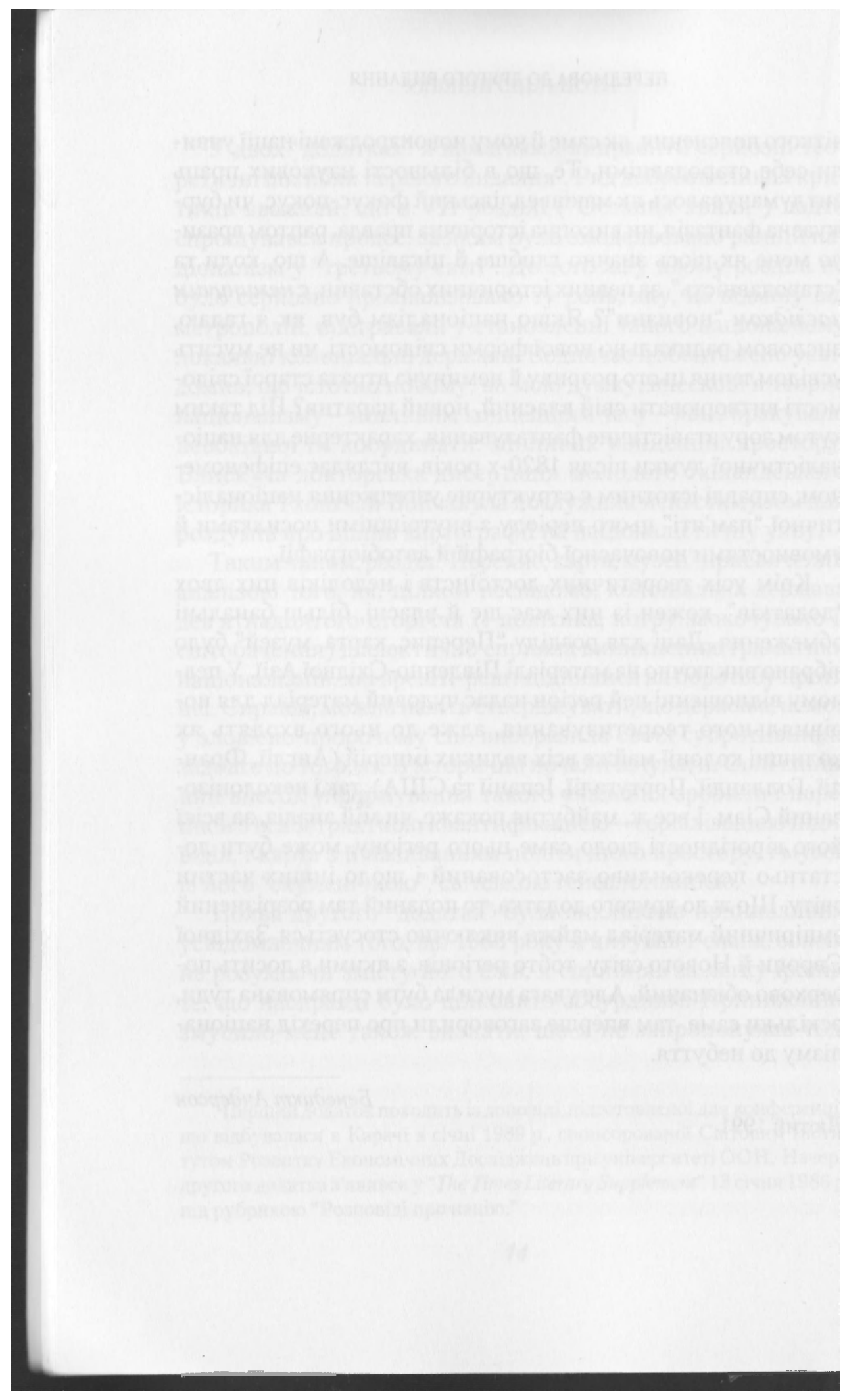




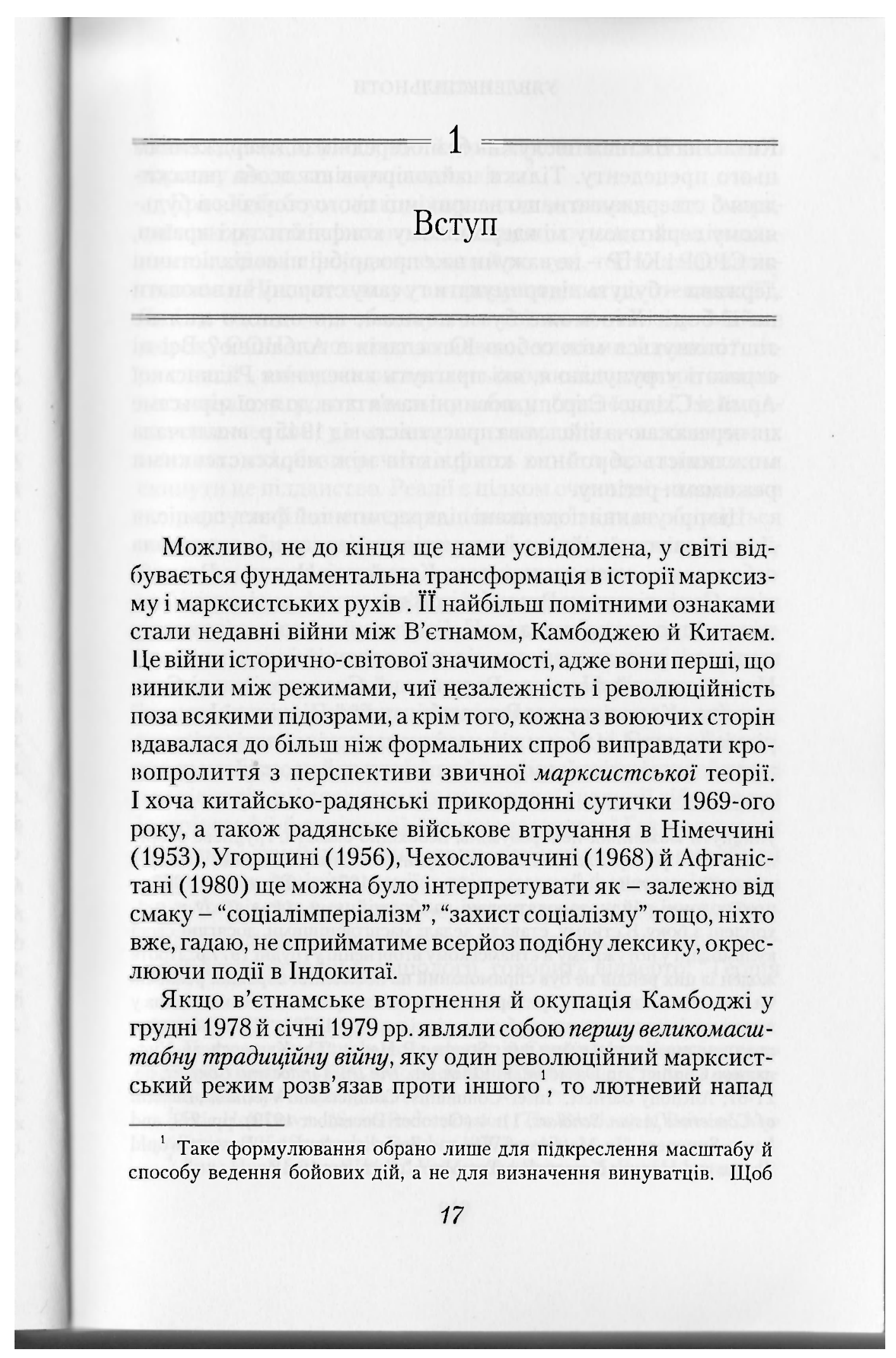


Китаю на В'єтнам послужив безпосереднім підтвердженням цього прецеденту. Тільки найдовірливіша особа наважилася б стверджувати, що наприкінці цього сторіччя в будьякому серйозному міждержавному конфлікти такі країни, як СРСР і КНР - не кажучи вже про дрібніші соціалістичні держави - будуть підтримувати ту саму сторону чи воювати на її боці. Хто може бути певним, що одного дня не зіштовхнуться між собою Югославія з Албанією? Всі ці строкаті угрупування, які прагнуть виведення Радянської Армії зі Східної Свропи, повинні пам'ятати, до якої міри саме ця переважаюча військова присутність від 1945 р. виключала можливість збройних конфліктів між марксистськими режимами регіону.

Ці міркування покликані підкреслити той факт, що після Другої світової війни кожна успішна революція визначала себе в національних термінах - Китайська Народна Республіка, Соціалістична Республіка В'єтнам тощо - i, таким чином, міцно закорінювались у територіально-соціальному просторі, успадкованому від дореволюційного минулого. Натомість, той факт, що Радянський Союз поділяє зі Сполученим Королівством Великобританії й Північної Ірландії рідкісну честь відмови від національності у назві, свідчить про те, що він тією ж мірою є спадкоємцем донаціональних

уникнути можливих непорозумінь, необхідно сказати, грудневе вторгнення 1978 р. виросло із військових сутичок між партизанами двох революційних рухів, початок яких сягав чи не 1971 р. Від квітня 1977 р. прикордонні рейди, започатковані камбоджійцями, але відразу ж підхоплені з боку В'єтнаму, ставали дедалі масштабнішими, досягши своєї кульмінації у потужному в'єтнамському вторгненні у грудні 1977 р. Проте жоден із цих рейдів не був спрямований на повалення ворожих режимів чи захоплення значних територій, а кількість залучених військ не йшла у жодне порівняння з тими, що були задіяні в грудні 1978 р. Шодо полеміки стосовно причин цієї війни див.: Stephen P. Heder. "The Kampuchean-Vietnamese Conflict", in David W. P. Elliot, ed., The Third Indochina Conflict, pp. 21-67; Anthony Barnett. "Inter-Communist Conflicts and Vietnam", Bulletin of Concerned Asian Scholars, 11: 4 (October-December 1979), pp. 2-9; and Laura Summers. "In Matters of War and Socialism Anthony Barnett would Shame and Honour Kampuchea Too Much", ibid., pp. 10-18. 
династичних держав, що й предтечею наднаціонального порядку двадцять першого століття".

Ерік Хобсбоум цілком справедливо заявляє, що "марксистські рухи й держави мали тенденцію ставати національпими не тільки формально, але й по суті, тобто націоналістичними. Ніщо не вказує на призупинення цієї тенденції". SІк і на те, що вона обмежується світом соціалізму. Майже щороку ООН поповнюється новими членами. І деякі зі “старих націй”, які вважалися колись сконсолідованими, опинились перед загрозою виклику з боку “підлеглих" їм націопальних меншин у межах власних кордонів - національних меншин, які, безперечно, мріють одного щасливого дня 'кинути це підданство. Реалії $є$ цілком очевидні - давно вже папророчений "кінець ери націоналізму" ніяк не збирається иаставати. I справді, національний статус є загальновизнапою вартістю політичного життя нашого часу.

Утім, якщо факти зрозумілі, їх пояснення залишається предметом тривалої дискусії. Нація, національність, націопалізм - всі ці поняття завжди з труднощами піддавалися визначенню, не кажучи вже про аналіз. Порівняно з вели'єезним впливом, який націоналізм справив на сучасний світ, теоретично він залишається немічним. Хыю Сетон-Вотсон, автор, мабуть, найкращої й найповнішої англомовної праці ; націоналізму і спадкоємець поширеної традиції ліберальної історіографії й соціології, з сумом зазначає: “Таким чином я змушений прийти до висновку, що неможливо виробити «наукову дефініцію» нації; а втім, сам цей феномен існував і існує". Том Нейрн, автор основоположного "Розпаду Британії" та спадкоємець не менш поширеної традиції марксистської історіографії й соціології, говорить відверто: “Теорія

${ }^{2} \mathrm{Ti}$, хто мають сумніви щодо претензій Сполученого Королівства до подібного паритету з СРСР, повинні поцікавитись, що ж то за національність: великобрито-ірландець?

Eric Hobsbawm. "Some Reflections on "The Break-up of Britain", New Left Review, 105 (September-October 1977), p. 13.

Див.: Hugh Seton-Watson. Nations and States, p. 5. Виділено нами. 
націоналізму - це велика історична поразка марксизму”’. Але навіть це зізнання є дещо оманливим, оскільки може створити враження сумного наслідку тривалого й свідомого пошуку теоретичної ясності. Точніше було б сказати, що націоналізм виявився для марксистської теорії незручною аномалією і, саме 3 цієї причини, здебільшого просто ігнорувався нею. Чим ще можна пояснити те, що Маркс так і не витлумачив ніяк принципово важливий займенник свого знаменитого формулювання 1848 р.: "Пролетаріат кожної країни повинен, звичайно, перш за все розібратися зі своєю власною буржуазією" "? Як зрозуміти використання протягом понад сторіччя конщепту “національної буржуазії” без жодної серйозної спроби дати теоретичне обгрунтування доречності цього прикметника? Чому такий поділ буржуазії - світового, 3 огляду на виробничі відносини, класу $-\epsilon$ теоретично важливим?

Метою цієї книги було внести деякі попередні пропозиції щодо кращої інтерпретації "аномалії" націоналізму. Я відчуваю, що й марксистська, й ліберальна теорії з цього питання вже вичерпались у своїй пізньоптолемеївській спробі "врятувати феномени"; отже, вкрай необхідною є переорієнтація перспективи, так би мовити, в дусі Коперника. Моя вихідна позиція полягає в тому, що національність, або, якщо комусь це слово здається надто багатозначним, національна приналежність, так само, як і націоналізм, є культурними артефактами особливого роду. Щоб зрозуміти їх належним чином, необхідно ретельно дослідити, як саме вони виникли до історичного буття, в який спосіб змінювалося іх значення протягом часу і чому нині вони викликають такий потужний емоційний відгук . Я постараюсь довести, що створення цих

"Див.: Tom Nairn. "The Modern Janus", New Left Review, 94 (NovemberDecember 1975), р. 3. Цей нарис включено без змін до “The Break-up of Britain" (chapter 9, pp. 329-363).

${ }^{6}$ Karl Marx and Friedrich Engels. The Communist Manifesto, in the Selected Works, I, p. 45. Виділено нами. Слово "звичайно", вжите в будь-якій теоретичній праці, відразу 6 мало насторожити уважного читача. 
.ртсфактів наприкінці вісімнадцятого сторіччя ${ }^{7}$ було процсом спонтанної дистиляції складної суміші незалежних к"ю)ичних сил; проте, утворившись, вони стали "модульиими", здатними, з різною мірою самоусвідомлення, до I рансплантації на різноманітні соціальні терени, до того, щоб ॥ю)линати і бути поглиненими найрізноманітнішими полігиними й ідеологічними утвореннями. Я також спробую и)казати, чому ці специфічні культурні пам'ятки викликали д) себе таку глибоку відданість.

\section{Концепти та дефініції}

Перш ніж давати відповідь на всі ці питання, варто було б кюротко розглянути концепцію "нації" й запропонувати якусь робочу дефініцію. Досить часто теоретиків націона'ізму збивали з пантелику, а то й відверто дратували на'”упні три парадокси: 1. Об'єктивна новочасність націй в 'ฯах істориків супроти їхньої суб'єктивної стародавності в итах націоналістів. 2. Формальна універсальність соціо-культурного концепту національності - в сучасному світі кожна юсоба може, здатна й повинна "мати” національність тією ж мірою, що й стать - супроти неуникненної специфічності кинкретних ії виявлень, до тієї міри, що "грецька" національиість вже за визначенням є унікальною. 3. "Політична" сила иаціоналізму порівняно з його філософською убогістю i павіть непослідовністю. Інакше кажучи, на відміну від інших -ізмів, націоналізму не вдалося породити власних видатних

Як зазначає Айра Кеміляйнен, “батьки-засновники” академічного ıаукового націоналізму Ганс Кон і Карлтон Гейз переконливо доводили иравомірність саме цієї дати. Ніхто, мені здається, не піддавав серйозним сумнівам ці висновки, за винятком націоналістичних ідеологів певних країн. Кеміляйнен також зауважує, шо слово "націоналізм" увійшло до широкого загального вжитку лише наприкінці дев'ятнадцятого століття. Воно, скажімо, не зустрічалося в багатьох типових словниках дев'ятнадцятого століття. Коли Адам Сміт говорив про багатство “націй", він мав на увазі під цим терміном “суспільства" або "держави". Aira Kemilainen. Nationalism, pp. 10, 33 and 48-49. 
мислителів, таких, як Гоббс, Токвіль, Маркс чи Вебер. Ця “порожнеча" з легкістю дає підстави космополітичним і полімовним інтелектуалам легковажити ним. Подібно до Гертруди Стайн при виді мосту Оукленд, можна поспішно зауважити: “що в ньому особливого?” Характерно, що навіть такий прихильний дослідник націоналізму, як Том Нейрн, все-таки писав: "Націоналізм" є патологією сучасної еволюційної історії, так само неуникною, як індивідуальний “невроз”, з тією ж властивою йому двозначністю, з подібною схильністю до нападів божевілля, закорінених у дилемах безпорадності, перед якими стоїть більшість світу (щось на зразок інфантильності суспільств), і здебільшого невиліковних"

Частково проблема полягає в тому, що ми підсвідомо схильні уявляти існування Націоналізму з великої літери (так само, як і Віку з великої літери) і слідом за тим класифікувати "його" як ідеологію взагалі. (Зазначимо: коли кожний має якийсь конкретний вік, Вік $€$ тільки аналітичним виразом.) Гадаю, що справа виглядала б простіше, коли б ми трактували його в одному ряду з поняттями "кровної спорідненості” і "релігії”, ніж “лібералізму” чи "фашизму".

Таким чином, в антропологічному смислі я пропоную наступне визначення нації: це уявлена політична спільнота при тому уявлена як генетично обмежена і суверенна.

Вона уявлена тому, що представники навіть найменшої нації ніколи не знатимуть більшості зі своїх співвітчизників, не зустрічатимуть і навіть не чутимуть нічого про них, і все ж в уяві кожного житиме образ ї співпричетності. Цю уявленість у властивій йому ввічливо-двозначній манері згадував Ренан, коли писав, що “Or l'essence d'une паtion est que tous les individus aient beaucoup de choses en commun, et aussi que tous aient oublir bien des choses" (Суттю нації $€$ те, що всі

${ }^{8}$ The Break-up of Britain, p. 359 .

${ }^{9}$ Порівн. Seton-Watson. Nations and States, p. 5: “Я можу лише сказати, що нація існує, коли значна кількість людей певної спільноти вважає, шо формує націю, або ж поводять себе так, ніби вже їі сформували". Можна витлумачити "вважають себе" як "уявляють себе." 
встуП

індивіди поділяють багато спільних речей, а також багато речей забувають) ${ }^{10}$. Дещо прямолінійно подібну ж думку висловлює й Геллнер, проголошуючи що "націоналізм - це не пробудження націй до самоусвідомлення: він вигадує нації там, де їх ще не існуе" ${ }^{\prime 1}$. Недоліком, одначе, цього формулювання є те, що Геллнер, прагнучи показати, як облудно маскується націоналізм, прирівнює "вигадування" радше до “фабрикації" й "фальшивки”, аніж до “уявлення" і “творения". В такий спосіб він припускає існування "справжніх" спільнот, які можна з успіхом протиставляти націям. Насправді ж, будь-яка спільнота, більша за первісне поселення 3 безпосередніми контактами між мешканцями (хоча, можливо, й вона), є уявленою. Спільноти потрібно розрізшяти не за їхньою справжністю чи несправжністю, а за мапсрою уявлення. Яванські селяни завжди знали про свій зв'язок із людьми, яких ніколи не бачили, але ці узи уявлялися ім партикуляристично - як нескінченно продовжувана мережа кровної спорідненості й клієнтарності. Ще донедавна 13 яванській мові не було слова, яке виражало б абстрактне ноняття "суспільство". Нині ми сприймаємо французьку . иистократію ancien regime як окремий клас; але таке уявлення про неї виникло, безперечно, досить пізно ${ }^{12}$. Зви"айною відповіддю на питання "Хто такий Віконт де А?" було 6 не "представник аристократіі", а "власник маєтку A", "дядько Барона де Б” або “підлеглий Герцога де В”.

${ }^{10}$ Ernest Renan. "Qu'est-ce qu'une nation?" in OEuvres Completes, 1, p. 892. Він додає: “tout citoyen français doit avoir oublie la Saint-Barthélemy, les massacres du Midi an XIIIe siecle. Il n'y a pas en France dix familles qui fuissent fournir la preuve d'une origine franque..." (багато хто з французів июнинен був би вже забути про варфоломіївську ніч, про різанину на |)анцузькому півдні в XIII ст. Ви не знайдете у Франції й десятка родин, икі могли 6 аргументовано викласти історію походження франків...).

${ }^{11}$ Ernest Gellner. Thought and Change, p. 169. Виділено нами.

${ }^{12}$ Хоб́ббоум, так би мовити, “зафіксовує” іiі, стверджуючи, шо в 1789 р. iï кількість становила близько 400,000 при населенні в $23,000,000$. (Див. \|юо "The Age of Revolution", р. 78). Але чи хто уявляв собі подібний "гатистичний образ аристократії в дореволюційній Франції? 


\section{УЯВЛЕНІ СПІЛЬНОТИ}

Нація уявляється обмеженою, бо навіть найбільша з них, налічуючи сотні мільйонів людей, має свої межі, нехай навіть і еластичні, поза якими знаходяться інші нації. Жодна нація не уявляс себе рівнозначною людству. Навіть найбільш месіяністичні націоналісти не мріють про той день, коли всі представники людської раси об'єднають свої нації в одну, подібно до того, як у певні епохи, скажімо, християни мріяли про повністю християнізовану планету.

Вона уявляється суверенною, бо сам концепт народився в епоху, коли Просвітництво й Революція руйнували легітимність боговстановленої й ієрархічної династичної держави. Досягаючи зрілості на тому етапі людської історії, коли навіть найпалкіші послідовники будь-якої з універсальних релігій неминуче зіштовхувалися з очевидним плюралізмом цих релігій і аломорфізмом між онтологічними претензіями й територіальним поширенням кожної віри, нації прагнули отримати свободу, якщо вже й підлягати Богу, то без посередників. Емблемою та символом цієї свободи стас суверенна держава.

Нарешті, вона уявляється спільнотою, адже, незважаючи на фактичну нерівність і експлуатацію, які там панують, нація завжди сприймається як глибоке й солідарне братерство. У кінцевому підсумку, саме це братерство й робило можливим протягом останніх двох сторіч для мільйонів людей не лише вбивати, але й охоче віддавати своє життя в ім'я таких обмежених уявлень.

Ці смерті раптово ставлять нас віч-на-віч перед центральною проблемою націоналізму: яким чином уявні цінності недавньої історії (яким ледве чи більше двох сторіч) продукують такі колосальні жертви? Мені здається, що відповідь на це питання треба шукати серед культурних коренів націоналізму. 


\section{Культурні корені}

В новітній культурі націоналізму жодні символи не приковують більшої уваги, ніж пам'ятники й могили Невідомих слдатів. Публічні ритуальні почесті, якими вшановують ці монументи саме тому, що вони залишаються навмисно порожніми або ж ніхто не знає; хто там лежить, фактично не мають жодних історичних прецедентів ${ }^{1}$. Щоб відчути всю силу цього нововведення, варто лише уявити, якою була б : агальна реакція, якби хтось раптом "відкрив" ім'я Невідомого солдата чи став би домагатися, щоб кенотаф заповнили сиравжніми кістьми. Святотатство дивного, новітнього типу! Проте, хоч ці могили й позбавлені розпізнаваних тлінних "станків або нетлінних душ, вони, однак, заповнені примарними національними уявленнями . (Ось чому так багато різ-

\footnotetext{
' У стародавніх греків існували пам'ятники-кенотафи, але вони були мюдені на честь певних відомих осіб, чиї тіла, з тієї чи іншої причини, не мюжна було врятувати для нормального поховання. Цією інформацією я зівдячую моїй колезі - візантиністу Джудіт Геррін.

- Зверніть, приміром, увагу на ці відомі тропи: 1. "Довгий сірий стрій піколи нас не зраджував. В хвилини вагань мільйони привидів у брунатıюму хакі, в сіроголубих захисних уніформах здійнялися б зі своїх білих хрестів, вигукуючи грізно магічні слова: Обов'язок, Честь, Вітчизна".
} 
них націй мають подібні могили, не відчуваючи жодної потреби з'ясовувати національність їхніх відсутніх мешканців. Ким же вони ще можуть бути, як не німцями, американцями, аргентинцями?..)

Культурна значимість таких монументів стає ще зрозумілішою, коли спробувати уявити, скажімо, могилу Невідомого марксиста або пам'ятник полеглим лібералам. Чи не виглядає це повним абсурдом? Справа в тому, що ні марксизм, ні лібералізм не переймаються особливо питаннями смерті й безсмертя. Якщо ж націоналістична уява цим так цікавиться, це наводить на думку про її глибоку спорідненість з уявою релігійною. Оскільки ця спорідненість аж ніяк не випадкова, варто було б розпочати розгляд культурних коренів націоналізму з відношення до смерті як останньої з усіх можливих невідворотностей.

Якщо спосіб, в який людина вмирає, є справою капризу, ії смертність $€$ неуникненною. Людські життя заповнені такими поєднаннями неминучості й випадку. Ми всі усвідомлюємо припадковість і невідворотність нашої індивідуальної генетичної спадщини, статі, життєвого циклу, фізичних можливостей, рідної мови тощо. Великим достоїнством традиційних релігійних світоглядів (не беручи, звичайно, до уваги їх роль в легітимації специфічних систем панування й експлуатації) була їхя зацікавленість “людиною в космосі", людською істотою як видом і випадковістю життя. Дивовижність самого факту виживання буддизму, християнства або ісламу впродовж тисяч років у десятках різних соціальних

2. "Моє ставлення [до американського воїна] сформувалося на полі бою багато років тому і з того часу не змінилось. I зараз, і тоді я вважав його однією з найшляхетніших у світі постатей; його військова репутація не тільки одна з кращих, але й одна з найменш заплямованих [sic]... Він належить історії, подаючи чи не найбільший приклад успішного патріотизму [sic]. Він належить нашадкам, виховуючи майбутні покоління на принципах свободи й незалежності. Він, з усіма своїми досягненнями й заслугами, належить і нам, сучасникам". Douglas MacArthur. "Duty, Honour, Country", Address to the U.S. Military Academy, West Point, May 12, 1962, in his $A$ Soldier Speaks, pp. 354 and 357. 
|)юрмацій свідчить про їхній винахідливий відгук на немисленні людські страждання - хвороби, каліцтва, горе, ‘тарість та смерть. Чому я народився сліпим? Чому мій найкаций друг паралізований? Чому моя донька $€$ розумово підсталою? Релігії намагаються знайти пояснення. Найбільпою вадою всіх еволюційних та прогресивних манер мисл'ıня, включаючи марксизм, $є$ те, що замість відповіді на ці шитаня ми отримуємо роздратовану мовчанку ${ }^{3}$. Водночас, $y$ рі:зі способи, релігійна думка реагує також на приховані патяки на безсмертя, трансформуючи здебільшого фатальпість у безперервність (карма, первородний гріх тощо). ' 'аким чином, вона цікавиться зв'язками між мертвими й ще шспародженими, таємницею регенерації. Хто ж, пережива"'чи зачаття й народження власної дитини, не усвідомлював ıсвиразно, як у понятті “безперервність" зливаються в одне иіле поєднаність, випадок і фатальність? (І знову, недоліком сволюційного/прогресивного мислення є майже Гераклітів$\cdots$ ка ворожість до самої ідеї безперервності.)

צІ тут приводжу ці, можливо, простодушні зауваження июрш за все тому, що в Західній Європі вісімнадцяте сторіччя шаменувало не тільки схід ери націоналізму, але й сутінки релігійних способів мислення. Століття Просвітництва, раціонального секуляризму, принесло з собою новітню темןяву. 3 занепадом релігійної віри страждання, яке ця віра

'Порівн. Regis Debray. "Marxism and the National Question", New Left Rrview, 105 (September-October 1977), р. 29. Працюючи в 1960-ті роки в Іидюнезії, я був вражений незворушною відмовою багатьох мусульман прийняти ідеї Дарвіна. Спочатку я тлумачив цю відмову як обскурантизм. З Һюдом я зрозумів її як чесне намагання бути послідовними: еволюційна люктрина була просто несумісна з ученням Ісламу. Що ми можемо сказати I ириводу наукового матеріалізму, який формально визнає відкриття | |ізики в галузі матерії, проте майже не робить спроб пов'язати ці відкриття , проблемами класової боротьби, революції чи чого б там не було. Чи не приховує ця безодня між протонами й пролетаріатом невизнану мета|різичну концепцію людини? Див. однак обнадійливі тексти Sebastiano Iimpanaro "On Materialism" та "The Freudian Slip"; а також вдумливу на пих відповідь Raymond Williams "Timpanaro's Materialist Challenge”, New l.eft Review, 109 (May-June 1978), pp. 3-17. 
частково вгамовувала, не зникло. Ніщо не робить приреченість більш несправедливою, ніж думка про зруйнований рай. Ніщо не робить інший тип безперервності більш необхідним, ніж думка про абсурдність спасіння. Саме тому й виникла необхідність секулярної трансформації фатальності у безперервність, випадковості у значимість. Як ми ще пересвідчимось, ніщо не відповідало (відповідає) цій меті краще, ніж ідея нації. Якпо національні держави визнаються повсюди явищем "новим" та "історичним", то нації, яким вони надають політичного виразу, виникають завжди з незапам'ятного минулого ${ }^{4} \mathrm{i}$, що найважливіше, прямують до безконечного майбутнього. Чари націоналізму обертають випадок на долю. Ми можемо повторити слідом за Дебре: "Так, я народився французом цілком припадково, але ж, зрештою, Франція - вічна".

Я, зрозуміло, не стверджую, що поява націоналізму наприкінці вісімнадцятого століття була “спричинена" ерозією релігійних догм і що сама ця ерозія не потребує глибокого дослідження. Також я не говорю про те, що націоналізм якимось чином історично "витісняе" релігію. Я лише пропо-

${ }^{4}$ Покійний президент Сукарно завжди цілком широ говорив про 350 років колоніалізму, яких зазнала його "Індонезія", хоча самий концепт "Індонезії" є винаходом двадцятого сторіччя, а більша частина теперішньої Індонезії була завойована голландцями лише між 1850 і 1910 pp. Одним із найвидатніших національних героїв сучасної Індонезії є яванський принц Діпонегоро з початку дев'ятнадцятого сторіччя, хоча, згідно з його власними мемуарами, принц мав наміри радше "підкорити [не звільнити!] Ябу", аніж вигнати звідти "голландців". І справді, він явно не уявляв "голландців" як певну сукупність. Див. Harry J. Benda and John A. Larkiп, eds. The World of Southeast Asia, p. 158; and Ann Kumar. "Diponegoro (1778?1855)”, Indonesia, 13 (April 1972), p. 103. Виділено нами. Подібним чином, Кемаль Ататюрк назвав один зі своїх державних банків "Eti Banka" (Хетським банком), а інший Шумерським банком. (Seton-Watson. Nations and States, p. 259). Ці банки нині процвітають, і немає причин сумніватися в тому, що багато хто з турків, включаючи, мабуть, і самого Кемаля, з усією серйозністю сприймали і сприймають хетів та шумерів як своїх предків. Перш ніж посміхатися, нам варто пригадати міфи про Артура та Боадіцею, а також зважити на комерційний успіх міфографій Толкіна. 


\section{КУЛЬТУРНI КОРЕНI}

иую спробувати збагнути націоналізм, співставляючи його не з усвідомленими політичними ідеологіями, а з масштабними культурними системами, які йому передували, і з яких та всупереч яким - він і народився.

Для наших цілей відповідними культурними системами г дві - релігійна спільнота і династична держава. Обидві в часи розквіту сприймалися як самозрозумілі й очевидні, полібно до того, як національність сьогодні. Ось чому важливо зрозуміти, що саме надало цим культурним системам таку самоочевидну вірогідність, і в той же час виділити деякі ключові елементи, що спричинились до їхнього розпаду.

\section{Релігійна спільнота}

Мало шо так вражає, як широка територіальна поширепість світів ісламу - від Марокко до Зулуського Архіпелагу, християнства - від Парагваю до Японії, та буддизму - від IIIрі Ланки до Корейського півострова. Великі сакральні культури (а ми можемо соди включити й “конфуціанство") птілювали концепції неосяжних спільнот. Але християнство, світ ісламу (Ummah Islam) і навіть Серединна імперія - яка, попри те, що ми думаємо про неї як про китайську, вважала себе не китайською, а центральною - здебільшого уявляли ссбе за посередництвом сакральної мови й тексту. Взяти хоча б іслам: коли мешканці Магвінданао зустрічалися в Мецці з берберами, то, не знаючи відповідних мов, не маючи змоги спілкуватися усно, вони тим не менше розуміли знаки, ідеограми один одного, тому що спільні для них сакральні тексти існували тільки на класичній арабській мові: В цьому смислі І иисемна арабська мова функціонувала подібно до китайської ієрогліфіки, організовуючи спільноту навколо знаків, не звуків. (Так нині продовжує стару традицію мова математики. Румуни не мають жодного поняття про те, як вимовлясться по-таїландськи + , і навпаки, але всі вони розуміють значення цього знака.) Всі великі класичні суспільства мислили себе космоцентричними завдяки сакральній мові, зв'язаній з надземними силами. Відповідно, простір дії писемної 
латини, палі, арабської й китайської мов був, теоретично, необмеженим. (По суті, чим мертвішою була писемна мова чим далі від розмовної - тим краще: всі, в принципі, мають доступ до чистої сфери знаків.)

Проте такі класичні спільноти, з'єднані сакральними мовами, відрізнялися від уявних спільнот сучасних націй. Однією $з$ таких ключових відмінностей була впевненість старих спільнот в унікальній сакральності своїх мов, 3 чого випливало їхнє відношення до прийняття нових членів. Китайські мандарини схвально ставилися до варварів, які старанно училися вимальовувати ієрогліфи Серединної імперії. Ці варвари вже знаходилися на півдорозі до повного поглинення ${ }^{5}$. Напівцивілізована особа була набагато краща від варвара. Таке відношення, звичайно ж, було властиве не тільки китайцям і не обмежувалося стародавніми часами. Зверніть, скажімо, увагу на “політику щодо варварів", яку сформулював колумбійський ліберал початку дев'ятнадцятого століття Педро Фермін де Варгас:

3 метою поширення сільського господарства необхідно іспанізувати наших індіанців. Їхня ледачість, тупість і байдужість до нормальних зусиль примушує думати, що вони походять зі звироднілої раси, яка занепадає пропорційно віддаленості від своїх першопочатків... було б дуже бажаним викорінити індіанців иляхом мішаних шлюбів із білими, звільнения від данини та іниих податків інадання ім приватно власності на землюб.

Вражає, як цей ліберал ще пропонує “викорінювати" своїх індіанців, “звільняючи їх від данини” й “надаючи їм приватну власність на землю”, замість того, шоб винищувати іх за допомогою рушниць і бактерій, що незабаром почали здійснювати його наступники в Бразилії, Аргентині й Сполучених

5 Звідси й незворушність, 3 якою приймали до Небесних Синів китаїзованих монголів і маньчжурів.

${ }_{6}^{6}$ John Lynch. The Spanish-American Revolution, 1808-1826, p. 260. Виділено нами. 


\section{КУЛЬТУРНІ КОРЕНІ}

IIIтатах. Варто також відмітити, поруч із поблажливою жор('окістю, такий собі космічний оптимізм: в кінцевому підсумку, індіанцю доступне спасіння - він досягне його заплідиившись білим, “цивілізованим” сім'ям і отримавши привітну власність, як усі. (Як відрізняється позиція Ферміна від точки зору пізніших європейських імперіалістів, які віддавали ıсревагу "справжнім" малайцям, гуркам і гауса над “полукровкіми”, “напівосвіченими тубілыцями”, “чужаками” тощо).

Однак якщо німі сакральні мови були засобом, завдяки икому уявляли себе глобальні спільноти минулого, їх реальні итілення спиралися на ідею досить таки чужу для сучасної : ахідної думки: невипадковістю знака. Ідеограми китайської, латинської або арабської мови являли собою еманацію реілььності, а не сфабрикований навмання ï образ. Нам знаиома тривала дискусія щодо мови (латини чи розмовної), гіцної меси. В ісламській традиції ще донедавна Коран у букнальному смислі був неперекладним (а отже й неперекладеинм), адже істину Аллаха можна було осягти лише через псзамінимі справжні знаки писемної арабської мови. Тут ще лс існує ідеї світу, настільки відділеного від мови, щоб усі мови сприймалися рівнодалекими (а отже взаємозамінюшацими) його знаками. В результаті, онтологічна дійсність ("'ає доступною розумінню тільки завдяки єдиній привілеііованій системі репрезентації: істинній мові церковної латини, арабської мови Корану або Екзаменаційної китай'юкої. Як мови істини, вони наділені імпульсом, переважно 'ужим націоналізмові, імпульсом до навертання. Під наверТанням я розумію не стільки визнання певних релігійних догматів, скільки алхімічне поглинення. Варвар стає членом “Серединної імперії", ріф - мусульманином, ілонго - хрис-

\footnotetext{
' Церковна грецька, судячи з усього, не досягла статусу істинної мови. (. багато причин цієї "невдачі", але одним із ключових факторів було, безперечно, те, шо грецька (на відміну від латини) залишилася живою иародною мовою в більшій частині Східної Імперії. Цією ідеєю я завдячую Цжудіт Геррін.
} 


\section{УЯВЛЕНІ СПІЛЬНОТИ}

тиянином. Ціла природа людської істоти є сакрально піддатливою. (Порівняймо престиж цих давніх світових мов, які гордо височать над усіма розмовними, з фактично зігнорованими есперанто чи волапюк). Зрештою, саме ця здатність до навертання засобами сакральної мови й давала можливість “англійцеві" ставати папою римським , а "маньчжуру" - Сином Небес.

Утім, хоча сакральні мови й робили можливим уявлення таких спільнот, як християнство, дійсні масштаби і привабливість цих спільнот не можуть бути пояснені самим лише сакральним текстом: врешті-решт, його освічені читачі були крихітними острівцями серед безмежного океану загальної неписьменності . Щоб з'ясувати це повніше, необхідно звернути увагу на відносини освічених людей зі своїми суспільствами. Помилково було б розглядати цю верству в якості такої собі теологічної технократії. Мови, хранителями яких вони були, хоча й герметичні, проте не мали нічого спільного з незрозумілістю юридичного чи економічного жаргонів, цілком маргінальних для уявлень суспільства про реальність. Навпаки, освічені люди були радше адептами, стратегічно важливою верствою в космологічній ієрархії, яка увінчувалась божеством ". Фундаментальні концепції щодо "соціальних груп" були скоріше організовані навколо центру й ієрархії, ніж навколо ідеї границь і горизонталі. Дивовижну владу папського престолу в часи його розквіту можна збагнути, лише прийнявши до уваги роль трансєвропейського духовенства, яке володіло письмовою латиною, та концепцію світу,

\footnotetext{
${ }^{8}$ Нікола Брейкспір займав посаду папи римського між 1154 та 1159 pp. під іменем Адріана IV.

${ }_{9}$ Марк Блок нагадує нам, що “білышість лордів і багато хто з вельможних баронів [в часи середньовіччя] правили, не вміючи особисто перевірити якийсь рахунок або звіт". Feudal Society, I, р. 81.

${ }_{10}$ Це не означає, що неосвічені люди зовсім не читали. Замість слів, вони прочитували видимий світ. "В очах тих, хто був здатний до рефлексій, матеріальний світ являв собою не більше ніж певну маску, за якою й відбувалися всі по-справжньому важливі речі; він їм також здавався мовою, призначеною виражати знаками значно глибшу реальність". Ibid., p. 83.
} 


\section{КУЛЬТУРНІ КОРЕНІ}

яку поділяли практично всі й згідно з якою двомовна інтеліюиція, будучи посередником між розмовною мовоюй латиною, була тим самим посередником між землею й небесами. (Страх исред відлученням віддзеркалює цю космологію.)

I все ж таки, попри всю величність і могутність великих релігійно уявлених спільнот, їх неусвідомлена щілісність певпинно слабшала починаючи від пізнього середньовіччя. Серед причин цього занепаду я хотів би тут виділити лише дві, що мають пряме відношення до унікальної сакральності цих спільнот.

Першою були наслідки відкриття не-європейського світу,

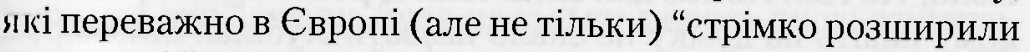
культурні й географічні горизонти, а також, відповідно, уявисиня про можливі форми людського життя" ${ }^{11}$. Цей процес простежується вже цілком очевидно в найвидатнішій зі всіх - пропейських мандрівних книг. Зверніть увагу, з яким благоi )зінням наприкінці тринадцятого століття достойний венеціанський християнин Марко Поло змалював Кубла Хана ${ }^{12}$ :

Великий хан, здобувши цю блискучу перемогу, тріумфально й помпезно повернувся до столиці Канбалу. Це сталося листопада місяця, і він перебував там впродовж лютого й березня місяців, під час останнього з яких відзначається наше свято Пасхи. Знаючи, що це одне з наиих головних торжеств, він наказав усім християнам прийти до нього й принести ӥхню Книгу, в якій містяться чотири Євангелія. Після церемонії кількаразового кадіння фіміамом, він побожно поцілував їі й те саме звелів зробити всім своїм присутнім вельможам. Він це звичайно практикував під час кожного з основних християнських свят, таких як Пасха і Різдво; так само він відзначав і сарацинські, єврейські та ідолопоклонницькі свята. Коли його запитали про мотиви такої поведінки, він відповів: " $Є$ чотири великих пророки, перед якими благоговіють і схиляються різні категорії людства. Християни

${ }_{12}^{11}$ Erich Auerbach. Mimesis, p. 282.

${ }^{12}$ Marco Polo. The Travels of Marco Polo, pp. 158-159. Виділено нами. . иуважте, шо Євангеліє цілували, але не читали.

2 
своїм божеством вважають Ісуса Христа; сарацини - Магомета; євреї - Мойсея; а ідолопоклонники - Согомомбархана, найвидатнішого зі своїх ідолів. Я ж поважаю й шаную ix усіх і закликаю собі на допомогу будь-кого, хто з них чотирвохє справді верховнии у небесах". Але, судячи з того, як його величність ставився до них, було очевидно, шо він вважає віру християн найістиннішою й найкрашою...

В цьому уривку вражає не стільки незворушний релігійний релятивізм великого монгольського правителя (це все-таки релятивізм реліzійний), скільки позиція й мова самого Марко Поло. Хоч він і писав для своїх таки європейських християн, йому навіть на думку не спало назвати Кубілая лицеміром чи ідолопоклонником. (Частково, безсумнівно, тому що "стосовно кількості підлеглих, масштабів території та суми прибутків він перевершує будь-кого з правителів, які були колись чи зараз $€$ на світі") ${ }^{13}$. А в несвідомому вживанні "нашого" (яке перетворюється в "іхню”) і в змалюванні віри християн як “найістиннішої”, а не просто “істинної”, ми можемо помітити зерна територіалізації вірувань, що проросли пізніше в мові багатьох націоналістів ("наша" нація $є$ “найкрашою" - в антагоністичній, порівняльній манері).

Як показово контрастує з цим вступ до листа, написаного перським мандрівником "Рікою" до свого приятеля "Іббена" з Парижа в “1712 p."

Папа римський $€$ найголовнішим із християн; він - старовинний ідол, перед яким зараз схиляються за звичкою. Колись він був грозою навіть для принців, бо міг усувати їх з такою ж легкістю, як наші величні султани позбавляють влади царів Імеретії чи Грузії. Але тепер його ніхто вже не боїться. Він себе вважає наступником одного 3 найперших християн, святого Петра, і це розкішна спадшина, адже багатства його незмірні, а під його контролем знаходиться велика країна.

${ }^{13}$ The Travels of Marco Polo, p. 152.

${ }^{14}$ Henri de Montesquieu. Persian Letters, p. 81. “Lettres Persanes" з'явилися вперше у $1721 \mathrm{p}$. 


\section{КУЛЬТУРНІ КОРЕНІ}

Навмисна й вишукана підробка, здійснена католиком 3 вісімнадцятого сторіччя, віддзеркалює наївний реалізм його потередника з тринадцятого століття, але тепер уже "релятивізм" $\mathrm{i}$ "територіалізація" стають цілком усвідомленими і політичними за своїми намірами. Чи так вже й безпідставно ибачати парадоксальний розвиток цієї традиції в ототожпснні аятолою Руголла Хомейні Великого Сатани не з єрессю 'III навіть з демонічним персонажем (безбарвний Картер аж иіяк сюди не пасував), а з начією?

Другою причиною був поступовий занепад самої сакральпої мови. Пишучи про середньовічну Західну Свропу, Блок ııзначав, що "латина була не тільки мовою, якою здійснюпілось навчання, але й єдиною мовою, яку вивчали взагалі" ( I ц слово “єдиною” дуже ясно вказує на сакральність латиIII - жодна інша мова не вважалася вартою вивчення.) Але иже в шістнадцятому столітті все це почало швидко мінятися. Мı тут не зупинятимося на причинах цієї зміни: значення і шілив капіталістичного друкарства обговорюватиметься пізіше. Достатньо буде лише нагадати його масштаби й жмпи. За оцінками Февра і Мартена, 77\% книг, які вийшли друком до 1500 р., були ще написані латиною (що все-таки ш.3Іачає, що 23\% були вже написані народними мовами) ${ }^{16}$. :кщю з 88 видань, надрукованих у Парижі в 1501 р., за шияятком восьми, усі були латиномовні, то після 1575 р. бі.ишість завжди належала франкомовним ${ }^{17}$. Незважаючи Iіi тимчасове повернення латини в часи Контрреформації, iї ютемонія була приреченою. I ми тут не говоримо лише про пін:ільну популярність. Трохи пізніше, але з не менш карколомною швидкістю, латина перестала бути мовою вищого прошарку панєвропейської інтелігенції. В сімнадцятому 'торіччі Гобс (1588-1678) був загальновизнаною на контищенті постаттю, тому що писав на мові істини. 3 другого боку

\footnotetext{
${ }^{15}$ Bloch. Feudal Society, I, p. 77. Виділено нами.

"Lucien Febvre and Henri-Jean Martin. The Coming of the Book, pp. 248-

${ }^{17}$ Ibid., p. 321.
} 249. 


\section{УЯВЛЕНІ СПІЛЬНОТИ}

Шекспір (1564-1616), який творив розмовною мовою, був практично невідомий по той бік Ла-Маншу ${ }^{18}$. I якби англійська не стала, двомастами роками пізніше, світовою імперською мовою, чи не залишався б він і надалі здебільшого незнаним поза Британськими островами? Тим часом, близькі ім сучасники з протилежного боку Ла-Маншу Декарт (15961650) і Паскаль (1623-1662) вели свою кореспонденцію переважно латиною; а от Вольтер (1694-1778) - практично повністю розмовною мовою ${ }^{19}$. "Після 1640 р., коли все менше книжок виходило латиною й усе більше мовами розмовними, друкарство переставало бути міжнародним [sic] підприємництвом" ${ }^{20}$. Одним словом, занепад латини став ознакою значно більшого процесу, в якому сакральні спільноти, об'єднані стародавніми сакральними мовами, поступово розколювалися, множилися й територіалізувалися.

\section{Династична держава}

В наш час, мабуть, нелегко уявити себе в світі, в якому династична держава була для переважної більшості єдиною мислимою "політичною" системою. Адже за своєю фундаментальною суттю "серйозна" монархія корінним чином відрізняється від усіх сучасних концепцій політичного життя. Монархія все зосереджує навколо верховного центру. Свою легітимність вона одержує від божества, а не від населення, яке, врешті-решт, складається з підлеглих, а не 3 громадян. За сучасною концепцією державний суверенітет здійснюється повністю, рішуче й рівномірно над кожним квадратним сантиметром законно розмежованої території. А за старими уявленнями, коли держави визначалися цент-

${ }^{18}$ Ibid., p. 330.

${ }^{19}$ Ibid., pp. 331-332.

${ }^{20}$ lbid., pp. 232-233. Оригінальний французький текст є стриманіший та історично точніший: “Tandis que l'on Odite de moins en moins d'ouvrages en latin, et une proportion toujours plus grande de textes en langue nationale, le commerce du livre se morcelle en Europe". L'Apparition du Livre, p. 356. 


\section{КУЛЬТУРНI КОРЕНI}

|ами, кордони були розмитими й нечіткими, а суверенітети иепомітно перетікали один в одний ${ }^{21}$. Звідси, як це не паралюксально, й та легкість, з якою домодерним імперіям і королівствам вдавалося на довгий час зберігати своє панування над надзвичайно різнорідними й нерідко навіть не суміжиими народностями ${ }^{22}$.

Необхідно також пам'ятати, що ці давні монархічні держави розширювалися не тільки завдяки війнам, але й зашдяки шлюбній політиці - цілком відмінній від тієї, що практикується сьогодні. Здійснюючи принцип вертикальності, династичні шлюби сприяли об'єднанню різних народностей під новими владарями. Показовою в цьому відношенні була династія Габсбургів. Як ішлось у відомій сентенпіiі: "Bella gerant alii tu felix Austria nube!" ("Нехай воюють іппі, а ти, щаслива Австріє, одружуйся!"). Ось, у дещо скороченому вигляді, титули династів останньоі. ${ }^{23}$ :

Імператор Австрії; Король Угорщини, Богемії, Далмації, Хорватії, Словенії, Галіції, Лодомерії та Іллірії; Король Єрусалимський тощо; Ерцгерцог Австрійський [sic]; Великий Князь Тосканський і Краківський; Герцог Лот[а]рінгський, Зальцбурзький, Штирії, Каринтії, Крайни й Букови-

${ }^{21}$ Зверніть увагу на зміни, яких зазнали найменування правителів у ш'язку з цією трансформацією. Школярі пам'ятають монархів за іхніми імснами (яке було прізвише Вільгельма Завойовника?), а президентів i: прізвишами (як звали Еберта?). В громадянському світі, коли будьх'о теоретично може стати президентом, обмежений набір "християн' 'ıких" імен робить їх непридатними для подібної специфікаційної функції. І Іатомість у монархіях, де правління зберігається за певним єдиним прізшицем, саме імена, з порядковими числами чи прізвиськами, забезпечують нсобхідне розмежування.

Тут можна мимохідь зазначити, що Нейрн цілком правомірно на:нває Акт 1707-го р. про унію між Англією й Шотландією “угодою патрииіїв", в тому сенсі, що творцями унії були політики-аристократи. (Див. йо10 чіткі аргументи у "The Break-up of Britain", pp. 136f.). Однак нелегко уявити, шоб подібної угоди досягли представники аристократії двох республік. Концепція Сполученого Королівства була, безперечно, вирішальпою сполучною ланкою для забезпечення домовленості.

${ }^{23}$ Oscar Jaszi. The Dissolution of the Habsburg Monarchy, p. 34. 
ни; Великий Князь Трансильванський, Маркграф Моравський; Герцог Верхньої й Нижньої Силезії, Модени, Парми, П'яченци й Гвастели, Аушвіцу й Сатору, Тешинський, Фріульський, Рагузький й Зарський; світлійший граф Габсбурзький й Тірольський, Кобурзький, Гюрзу й Градісек; Герцог Трієсту й Брізену; Маркграф Верхнього й Нижнього Лаузіцу та Істрії; Граф Гогенембсу, Фельдкірху, Брегенцу, Зонненбергу тощо; Повелитель Трієсту, Каттаро й верхнього рубежу Віндішу; Великий Воєвода Воєводини, Сербії... й т.д.

Це, як справедливо зауважує Ясі, було "не без ознак деякої комічності... свідоцтво незлічених шлюбів, гендлювань і захоплень з боку Габсбургів".

В державах із релігійно санкціонованим багатоженством складні системи багатоярусного конкубінату були фундаментальними для інтеграції цих держав. Фактично, престиж королівського роду, поза божественною аурою, нерідко залежав і від, сказати б, мішаних шлюбів ${ }^{24}$. Адже такі суміші були ознакою вищого статусу. Характерно, що в Лондоні не було правлячої “англійської" династії від одинадцятого століття (як не раніше); а до якої "національності" могли б ми віднести Бурбонів ${ }^{-5}$ ?

Протягом сімнадцятого сторіччя, однак, - 3 причин, на яких ми тут не зупинятимемось - сакральна монархія в За-

${ }^{24}$ Особливо в домодерній Азії. Але той самий принцип діяв і в моногамній християнській Європі. В 1910 р. якийсь Отто Форст видав "Ahnentafel Seiner Kaiserlichen und Königlichen Hoheit des durchlauchtigsten Hern Erzherzogs Franz Ferdinand", в якому нарахував 2047 предків Ерцгерцога, якого невдовзі уб'ють в Сараєво. Серед них було 1486 німпів, 124 французи, 196 італійців, 89 іспанців, 52 поляки, 47 датчан, 20 англійців та англійок, а також представники чотирьох інших націй. Цей “курйозний документ" наводиться в ibid., p. 136, по. 1. Я не можу втриматися, щоб не процитувати тут чудовий відгук Франца Йосифа на звістку про вбивство свого дивака-спадкоємця: "Таким чином найвища влада відновила той порядок, який я не міг, на жаль, підтримувати" (ibid., p. 125).

${ }_{25}$ Геллнер підкреслює типовість іноземного походження династій, але надто вузько інтерпретує це явище: місцева аристократія віддає перевагу чужоземному монарху, бо він не ставатиме на чийсь бік в іхній внутрішній боротьбі. Thought and Change, p. 136. 


\section{КУЛЬТУРНІ КОРЕНІ}

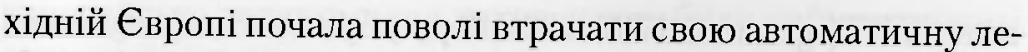
гітимність. В 1649 р., під час першої з революцій новітнього світу, було страчено Карла Стюарта, і впродовж 1650-х років однією з найповажніших європейських держав правив ıе король, а плебей Лорд-Протектор. Проте, навіть у часи Іопа й Аддісона, Анна Стюарт усе ще зцілювала хворих, пакладаючи на них королівські руки, й подібні лікування Іроводились також Бурбонами, Людовиками XV і XVI, y (Dранції доби Просвітництва до самого кінця "ancien regime. Але після 1789 р. принцип Легітимності вже потрібно було голосно й свідомо захищати, внаслідок чого “монархія" перетворилась у напівстандартизовану модель. Тенно й Син Небес ставали "Імператорами". В далекому Сіамі Рама V ("Уулалонгкорн) посилав своїх синів і племінників до СанктПетербурзького, Лондонського і Берлінського дворів навчаІися тонкощів світової моделі. В 1887 р. він запровадив обов'язковий принцип "спадкоємності за правом первородства", гим самим привівши Сіам "у відповідність 3 «цивілізованими» монархіями Європи" 1а трон неврівноваженого гомосексуаліста, якого, звичайно, риніше туди 6 не допустили. Однак міжмонархічне схвалепня його вступу на престол під іменем Рами VI було скріпл:не присутністю на коронуванні юних принців з Британії, Р'осії, Греції, Швеції, Данії... та Японії' ! Навіть у 1914 р. дипастичні держави все ще становили більшість у складі ‘nітової політичної системи, але, як ми розглянемо детально юодом, багато хто з династів уже підшукував птамп "націо"ілььності" в міру того, як старий принцип легітимності поволі відживав своє. Тоді, як армії Фрідріха Великого (правив I 1740 по 1786 рр.) комплектувалися значною мірою з “іно.'мців", війська його двоюрідного племінника Фрідріха Віль-

\footnotetext{
Marc Bloch. Les Rois Thaumaturges, pp. 390 and 398-399.

Noel A. Battye. "The Military, Government and Society in Siam, 18681910", PhD thesis, Cornell 1974, p. 270.

Stephen Greene. "Thai Government and Administration in the Reign of R:ıma VI (1910-1925)", PhD thesis, University of London 1971, p. 92.
} 
гельма III (правив з 1797 по 1840 рр.) були вже, в результаті імпозантних реформ Шарнхорста, Гнейзенау й Клаузевіца, винятково "національно-пруськими",

\section{Концепції часу}

Недалекоглядним було б, однак, уважати, що уявлені спільноти націй просто виросли з релігійних спільнот і династичних держав, замінивши їх собою. Занепад сакральних спільнот, родоводів і мов відбувався на тлі фундаментальної зміни в способах усвідомлення світу, яка, перш за все, й зробила можливим “вигадування" нації.

Для того, щоб відчути характер цієї зміни, варто придивитися до таких візуальних образів сакральних спільнот, як рельєфи й вітражі середньовічних храмів або живопис ранніх італійських і фламандських майстрів. Характерною ознакою цих зображень $\epsilon$ щось оманливо аналогічне до "сучасного вбрання". Пастухи, яких зоря привела до ясел, де народився Христос, виглядають, як селяни з Бургундії. Зображення Діви Марії нагадує доньку тосканського купця. В багатьох картинах, благоговійно вклякнувши поруч із пастухами, змальовуються меценати-замовники в пишних шатах бюргера чи вельможі. Те, що нині здається недоречним, виглядало, очевидно, цілком природнім в очах середньовічних прихожан. Перед нами постає світ, який зображав уявлену реальність надзвичайно зримо й відчутно. Християнство набувало своєї універсальної форми завдяки міріадам конкретних деталей: ось цей рельєф, ось той вітраж, ця проповідь, та історія, ця моралістична п'єса, та реліквія. Хоча транс-

${ }^{29}$ В 1806 р. понад 1,000 осіб з офіцерського складу прусської армії, який налічував 7,000-8,000 чоловік, були іноземцями. "Прусаків зі середніх верств у власній армії кількісно перевершували іноземці; це відповідало приказці про те, шо Пруссія - це не країна з армією, а країна при армії". В 1798 р. прусські реформатори вимагали "скорочення наполовину кількості іноземців, яких у рядовому складі налічувалось майже 50\%..." Alfred Vagts. A History of Militaiism, pp. 64 and 85. 


\section{КУЛЬТУРНІ КОРЕНІ}

'вропейське латиномовне духовенство було найістотнішим (лементом в структуруванні християнської образності, не мснш важливу роль відігравала передача ним своїх концепцій неписьменним масам за посередництвом візуальних і слухових образів, завжди індивідуалізованих і конкретних. Скромний приходський священик, чия суєтність була відома кожному з тих, хто слухав його проповіді, залишався однак прямим посередником між своїми парафіянами й небесами. Цце зіставлення космічно-універсального з індивідуальноземним означало, що християнський світ, яким би безмежшім він не був (або сприймався), являв себе по-різному в конкретній швабській або андалузійській громаді. Зображення Ціви Марії зі "семітськими" рисами чи в одязі з "першого сторігчя" в реставраційному дусі сучасного музею було немислимим, адже сприйняттю середньовічного християнина була чужа концепція історії як нескінченного ланцюга причин і наслідків :бо радикального розриву між минулим і сучасним ${ }^{30}$. Як зизачає Блок, люди думали, що наближається кінець світу, в тому сенсі, шо друге пришестя Христа могло настати будь-якої миті: св. Павло казав, що "день Господній прийде, як злодій упочі”. Таким чином, цілком природньо, що видатний хронікер XII cт. єпископ Отто Фрейзінгенський говорив постійно "ми, х'го опинились наприкінці віку". Блок приходить до висновку, що, коли середньовічні люди "віддавалися релігійним роздумам, менш за все їм уявлялася перспектива неозорого майбутнього для молодої й енергійної людської раси"з"

Незабутній начерк такої форми свідомості наводить Ауербах :

Якщо жертвоприношення Ісаака інтерпретувати як явище, що прообразує жертву Христа, так що перше знаходиться в

${ }^{30}$ Ідея "сучасного одягу", метафоричного еквіваленту між минулим і ' 'учасним, $є$ для нас непрямим визнанням цього фатального розриву.

${ }^{31}$ Bloch. Feudal Society, I, pp. 84-86.

2 Auerbach. Mimesis, p. 64. Виділено нами. Порівняйте з тим, як св. Августин називав Старий Завіт "тінню[яку відкидає] майбутнє". Цитата 4 Bloch. Feudal Society, I, p. 90. 


\section{УЯВЛЕНІ СПІЛЬНОТИ}

другому, як і було проголошено й обіцяно, й друге "здійснює"... перше, тоді встановлюється зв'язок між двома подіями, що не сполучені ані часово, ані причинно - зв'язок, Який неможливо встановити раціонально в горизонтальному вимірі... Він виникає лише тоді, коли обидва явища вертикально поєднані з Божественним Провидінням, яке єдине здатне розробити подібний задум історії та надати ключ для його розуміння... Тут і тепер не $\epsilon$ вже звичайною ланкою в ланцюзі земних подій, це $є$ водночас чимось, що було завжди і що здійсниться в майбутньому; а точніше, з Господньої перспективи, це щось вічне, щось позачасове, щось уже звершене в царстві фрагментарних земних подій.

Він справедливо зауважує, що така ідея одночасності є нам цілком чужою. Сприйняття часу тут є наближеним до того, що Бенджамін назвав "месіанським часом", одночасністю минулого й майбутнього в миттєвому сучасному ${ }^{33} .3$ цієї точки зору, вираз "тим часом" втрачає своє значення.

Наша власна концепція одночасності народжувалась досить довго, і ї̈ виникнення безумовно пов'язане - як саме, потребує ще детального дослідження - із розвитком секулярних наук. Однак це концепція такої фундаментальної ваги, що, не беручи ї̈ серйозно до уваги, нам буде важко досліджувати туманні витоки націоналізму. На зміну середньовічній концепції “одночасного часу" прийшла, якщо знову скористатися визначенням Бенджаміна, ідея "однорідного, порожнього часу", в якому одночасність є, так би мовити, поперечною, перехресною з часом, визначеною не прообразом і реалізацією, а тимчасовим співпадінням, і вимірюваною за допомогою годинника й календаря ${ }^{34}$.

Чому ця трансформація була настільки важливою для народження як уявної спільноти нації, можна найкраще зрозуміти, розглянувши основну структуру двох форм вимислу,

${ }^{33}$ Walter Benjamin. Illuminations, p. 265.

${ }^{34}$ Ibid., p. 263. Настільки глибинною $\epsilon$ ця нова ідея, що можна стверджувати про базування кожної істотної сучасної концепції на понятті "тимчасовості". 


\section{КУЛЬТУРНІ КОРЕНІ}

які вперше розквітли в Свропі у вісімнадцятому столітті: роману й газети ${ }^{35}$. Адже ці форми надали технічні засоби для "репрезентації" того типу уявної спільноти, яким і $є$ нація.

Розгляньмо спочатку структуру старомодного роману, структуру, типову не тільки для бальзаківських шедеврів, але й для будь-якого сучасного дешевого чтива. Це, поза всяким сумнівом, засіб для відтворення одночасності в “однорідному, порожньому часі", або складний коментар до прислівІика "тим часом". Візьмімо, для унаочнення, уривок простенького сюжету для роману, в якому певний чоловік (А) має жінку (Б) і коханку (В), в якої теж є коханець (Г). Можна уявити наступну, так би мовити, часову таблицю цього уривка:

\begin{tabular}{|c|c|c|c|}
\hline Yac & I & II & III \\
\hline IIoдii & $\begin{array}{l}A \text { сперечається з } E \\
B \text { i } \Gamma \text { кохаються }\end{array}$ & $\begin{array}{l}A \text { дзвонить } B \\
E \text { робить покупки } \\
\Gamma \text { грає в більярд }\end{array}$ & $\begin{array}{c}\Gamma \text { напивається } \\
\text { в барі } \\
A \text { обідає вдома } \\
\text { разом із } E \\
B \text { сниться } \\
\text { страшний сон }\end{array}$ \\
\hline
\end{tabular}

Зауважмо, що впродовж усіх цих сцен А і Г не зустрічаиться між собою, вони, фактично, можуть і не здогадатися 川ю існування один одного, якщо В була досить обережною ${ }^{36}$. II Цо ж тоді пов'язує А з Г? Дві додаткові концепти: по-перше, шни є часткою "суспільств" (Вессексу, Любеку, Лос-Анжелссу). Ці суспільства є соціологічними організмами, реальпість існування яких $є$ настільки сталою й тривкою, що мож-

1.5 Хоча "Принцеса де Клев" з'явилася вже в 1678 р., ерою Річардсона, Д‘(фо й Філдінга став початок вісімнадцятого сторіччя. Походження сучасıиї газети бере свій початок від голландських gazettes кінця XVII століття; пркте до розповсюдженої категорії друкованих матеріалів газета увійшла เ ільки після 1700 p. Febvre and Martin. The Coming of the Book, p. 197.

3. I справді, сюжетні перипетії в часах I, II і III можуть залежати від I)'о, що А, Б, В і Г не знатимуть про те, що затівають інші. 


\section{УЯВЛЕНІ СПІЛЬНОТИ}

на зобразити, як їхні представники (А і Г) розминаються на вулиці, так і не познайомившись, і все ж таки пов'язані". Подруге, А і Г є часткою свідомості всевідаючих читачів. Тільки вони, наче Бог, можуть одночасно слідкувати за тим, як А дзвонить по телефону В, Б ходить по крамницях, а Г грає в більярд. Те, що всі ці сцени розігруються в один і той самий час, зафіксований годинником та календарем, але акторами, які здебільшого нічого не знають одне про одного, підкреслює новизну цього уявного світу, створеного авторськими чарами в свідомості читачів ${ }^{30}$.

Ідея соціологічного організму, який переміщається згідно 3 календарем у однорідному, порожньому часі, є точним аналогом ідеї нації, що теж сприймається цілісною спільнотою, яка розмірено просувається крізь історію ${ }^{39}$. Пересічний американець ніколи не зустріне, та й навіть не знатиме імен нікого, крім малої дрібки з 240 з лишком мільйонів своїх співвітчизників. Він не має уявлення, чим вони займаються тієї або іншої хвилини. Але він абсолютно певний щодо їхньої постійної, анонімної, одночасної активності.

Можливо, перспектива, запропонована мною, виглядатиме меншг абстрактною, якщо ми коротко розглянемо чотири художні твори 3 різних культур і різних епох, усі 3 яких, крім одного, нерозривно пов'язані з національними рухами. В 1887 р. "батько філіппінського націоналізму" Хосе Рісаль написав роман “Noli Me Tangere”, який нині вважається найбільшим досягненням нової філіппінської літератури.

${ }^{3}$ Цим багатоголоссям сучасний роман рішуче відрізняється навіть від такої блискучої предтечі, як "Сатирикон” Петронія. Виклад подій розгортається там однолінійно. Коли Енколпій оплакує невірність своєї юної коханки, нам не показують одночасно Гіту в ліжку з Аскілтом.

${ }^{38}$ В цьому контексті повчально порівняти будь-який історичний роман із документами чи хроніками з описаної в ньому епохи.

${ }^{39}$ Ніџо так не свідчить про занурення роману в гомогенному, порожньому часі, як відсутність отих вступних генеалогій, шо часто брали свій початок від походження людини й були такою характерною особливістю старовинних хронік, легенд і священних книг. 


\section{КУЛЬТУРНI КОРЕНI}

Також це був мало не перший роман, написаний “indio", губільцем ${ }^{40}$. Ось як чарівно він починається ${ }^{41}$ :

Десь наприкінці жовтня Дон Сантьяго де лос Сантос, відомий усім як капітан Тьяго, влаштовував звану вечерю. Хоча, на відміну від своїх звичаїв, він оголосив про це щойно вдень, це вже стало єдиною темою розмов у Бінондо, в інших міських кварталах і навіть в [оточеному мурами внутрішньому місті] Інтрамурос. Капітан Тьяго мав тоді репутацію щедрого господаря. Всі знали, шо двері його дому, як і його країни, були відкриті для всього, крім торгівлі та будь-яких нових і несподіваних ідей.

Отож новина блискавицею розлетілась у середовищі дармоїдів, нахлібників і непрошених гостей, котрих Господь, у своій невичерпній доброті, сотворив і ласкаво розплоджує в Манілі. Одні полювали за ваксою для черевиків, інші розшукували комірці й краватки. Але всі переймалися тим, як привітати господаря з достатньою мірою фамільярності, що необхідна для створення враження давньої дружби, або, в разі чого, як виправдатися за запізнення.

Вечеря мала відбутися в будинку на Анлоуг Стріт. Ми не пригадуємо номера будинку, тому опишемо його так, щоб усі могли впізнати - звичайно, якщо він уже не зруйнований землетрусом. Ми не повіримо, шоб сам власник міг його знести, адже цим переважно займається Бог або Природа, 3 якими, до речі, наш Уряд уклав ряд контрактів.

Тут не потрібно багато коментарів. Достатньо зазначити, що вже на самому початку образ званої вечері (цілком новий

40 Рісаль написав цей роман колоніальною (іспанською) мовою, яка ю1ді була lingua franca для етнічно різнорідних євразійських і місцевих -мiт. Разом із романом вперше також виникла "національна" преса, не лище іспанською, але й такими "етнічними" мовами, як тагалозька й I "иканська. Див. Leopoldo Y. Yabes. "The Modern Literature of the Philippines", pp. 287-302, in Pierre-Bernard Lafont and Denys Lombard (eds), l.trtératures Contemporaines de l'Asie du Sud-Est.

${ }^{41}$ Jose Rizal. Noli Me Tangere (Manila: Instituto Nacional de Historia, 1978), 1. 1. Переклад [на англійську] мій. В той час, коли вийшло у світ перше ишдання "Уявлених спільнот", я не володів іспанською й таким чином мимоиюлі поклався на цілком недостовірний переклад Леона Марії Гверреро. 
для філіппінської літератури), яку обговорюють сотні безіменних, не знайомих між собою людей, в різних куточках Маніли, певного місяця певного десятиліття, відразу ж перетворюється в образ уявленої спільноти. А речення про “будинок на Анлоуг Стріт", котрий "ми... опишемо...так, щоб усі могли впізнати", відноситься до тих, хто й мав би впізнавати, тобто до насфіліппінських-читачів. Мимовільне переміщення цього будинку з "внутрішнього" часу роману до "зовнішнього" часу повсякденного життя читача [з Маніли] стає гіпнотичним підтвердженням сталості єдиної спільноти, яка охоплює собою дійових осіб, автора й читачів, і рухається вперед крізь календарний час $^{42}$. Зверніть теж увагу на стиль. Хоча й Рісаль не має найменшого уявлення про індивідуальні особливості своїх читачів, він звертається до них іронічно-інтимно, так, начебто анітрохи не сумнівається у близькості своїх з ними відношень .

Ніщо так не допоможе відчути раптову розірваність свідомості, про яку говорив Фуко, як порівняння "Nol" з найбільш відомим раніше літературним твором “індіанця" Франсиско Балагтаса (Балтазара) "Pinagdaanang Buhay ni Florante at ni Laura sa Cahariang Albania" ["Розповідь про Флоранта й Лауру в Албанському Королівстві”], перше друковане видання якого датоване 1861 р., хоча він був написаний, мабуть, ше в 1838 р. Ал Алже, хоча Балагтас був ще живий, коли народився Рісаль, внутрішній світ його шедевру кардинально відрізняється від світу "Noli". Місце дії - вигадана серед-

42 Зауважте, наприклад, як в одному реченні Рісаль делікатно переходить від минулого часу - "сотворив" (crio) - до теперішнього для нас із вами - "розплоджує" (multiplica).

${ }^{43}$ Лицьовим боком анонімної безликості читачів була/є миттєва популярність автора. Як ми побачимо, ця безвісність/популярність цілковито залежить від поширення друкарства при капіталізмі. Ще в 1593 р. завдяки завзятості домініканців у Манілі була опублікована "Doctrina Christiana". Та після цього ше протягом віків друкарство залишалось під суворим церковним контролем. Лише у 1860 р. розпочався процес лібералізації. Див. Bienvenido L. Lumbera. Tagalog Poetry 1570-1898, Tradition and Influences in its Development, pp. 35, 93.

${ }^{44}$ Ibid., p. 115. 


\section{КУЛЬТУРНІ КОРЕНІ}

иьовічна Албанія - абсолютно відірване в часі й просторі від Бінондо 1880-х рр. Герої - Флорант, албанський вельможахристиянин, і його вірний приятель Аладін, перський аристократ-мусульманин ("моро") - нагадують нам про Філіппіни тільки відносинами між християнами й моро. Якщо Рісаль навмисне розбавляє свою іспанську прозу тагалозькими словами для "реалістичного", сатиричного або націопального ефекту, то Балагтас неусвідомлено додає до своїх тагалозьких катренів іспанські фрази лише для того, щоб ıідсилити пишність і милозвучність звучання. "Noll" призначалося для читання, тоді як "Florante at Laura" треба було декламувати вголос. Найбільш вражає поводження Балагтаса з часом. Як зазначає Лумбера, "розвиток сюжету не відбувається згідно з хронологічною послідовністю. Розповідь Іочинається in medias res, тому вся історія розгортається перед нами через серію ретроспективних монологів" Іоловина з 399 катренів Ірисвячена описам дитинства Флоранта, його студентських років у Афінах і наступних військових подвигів, які подає сам герой у бесіді з Аладіном ${ }^{46}$. "Розмовна ретроспектива" була для Балагтаса єдиною альтернативою прямому однолінійному викладу. Якщо ми й цовідуємось про "одночасне" минуле Флоранта й Аладіна, то це пов'язане з їхніми бесідами, а не зі структурою поеми. Як сильно відрізняється від цього техніка роману: "Тієї ж весни, коли Флорант ще навчався в Афінах, Аладіна викинули з двору його сюзерена..." Балагтасу, по суті, ніколи не спадає на думку "помістити" своїх героїв у "суспільство" або поговорити про них з читачами. Також, поза солодкозвучıим потоком тагалозьких багатоскладових слів, майже нічого “()іліппінського” в тексті немає

\footnotetext{
${ }^{45}$ Ibid., p. 120.

Подібну техніку вживав Гомер. На цю тему див. Auerbach. Mimesis, ch. 1 ("Odysseus' Scar").

"Paalam Albaniang pinamamayanan ng casama, $t$, lupit, bangis caliluhan, acong tangulan mo, I, cusa mang pinatay sa iyo, I, malaqui ang panghihinayang".
} 


\section{УЯВЛЕНІ СПІЛЬНОТИ}

У 1816 р., за сімдесят років до створення "Noli", Хосе Хоакін Фернандез де Лізарді написав роман під назвою "El Periquillo Sarniento" ["Папуга зі сверблячкою"], чи не перший латиноамериканський твір цього жанру. За словами одного критика, цей текст є “жорстоким звинуваченням іспанського уряду Мексики: невігластво, забобони й корупція зображені як його найвиразніші риси" "88. На суть формальної побудови цього "націоналістичного" роману вказує наступний опис його змісту ${ }^{4.9}$ :

Від самого початку [герой, Папуга зі сверблячкою] потрапляє під погані впливи - неосвічені покоївки насаджують забобони, мати потурає його примхам, вчителі не мають ні здібностей, ні вміння привчити його до дисципліни. I хоч його батько $є$ розумним чоловіком, який хоче, щоб син займався корисною справою, а не поповнював ряди адвокатів і дармоїдів, надмірно любляча мати бере верх, посилаючи Перікільо, свого сина, до університету й гарантуючи таким чином те, що він навчиться хіба що марновірним нісенітницям... Попри всі зустрічі з добрими й мудрими людьми, Перікільо все-таки залишається безнадійним невігласом. Вiн не бажає працювати або займатись серйозними речами й стає послідовно священиком, гравцем, злодієм, учнем аптекаря, лікарем, клерком у провінційному містечку... Ці епізоди дають автору змогу зобразити лікарні, в'язниці, віддалені села, монастир $i$, водночас переконливо доводячи найголовніше - те, що іспанський уряд і система освіти заохочують дармоїдство й лінощі... Під час своїх пригод Перікільо кілька разів опиняється серед індіанців і негрів...

"Процавай, Албаніє, королівство зла, жорстокості, брутальності й облуди! Я, захисник твій, кого ти розпинаєш, оплакую ту долю, шо тебе спіткала”.

Цей відомий станс часто витлумачували як завуальоване свідчення філіппінського патріотизму, але Лумбера переконливо доводить, що така інтерпретація $є$ просто наведенням анахронічного глянцю. Tagalog Poetry, p. 125. Переклад [на англійську] Лумбери. Я трохи змінив його тагалозький текст у відповідності з виданням поеми 1973 р., базованим на виданні 1861-го р.

${ }_{48}^{48}$ Jean Franco. An Introduction to Spanish-American Literature, p. 34.

49 Ibid., pp. 35-36. Виділено нами. 


\section{КУЛЬТУРНІ КОРЕНІ}

Тут ми знову спостерігаємо за дією “національної уяви” в тому, як відбувається переміщення самотнього героя в сталому соціологічному ландшафті, з'єднуючи внутрішній світ роману зі світом зовнішнім. Цей авантюристичний tour d'horison - лікарні, в'язниці, віддалені села, монастирі, індіанці, негри - не $є$ однак tour du monde. Горизонт явно обмежений колоніальною Мексикою. Ніщо так не переконує нас у цій соціологічній тривкості, як послідовне вживання множини. $\Lambda$ дже це витворює соціальний простір, наповнений подібни$м и$ в'язницями, жодна з яких нічим не особлива, проте взяті разом, вони свідчать (своїм одночасним, відокремленим існуванням) про гнітючість цієї колонії ${ }^{50}$. (Порівняйте з біблійиими в'язницями. Вони ніколи не уявляються типовими для того чи іншого суспільства. Кожна з них, як та, скажімо, в икій Саломея була зачарована Йоанном Хрестителем, $\epsilon$ магічно винятковою.)

Нарешті, щоб ліквідувати ймовірність того, що, оскільки ï Рісаль, і Лізарді писали іспанською мовою, структури, які ми тут розглядали, є все ж таки “європейськими", подаємо иступ до оповідання "Semarang Hitam" ["Чорний Семаранг”], паписаного молодим індонезійським націоналкомуністом 3 трагічною долею Мас Марко Картодікромо и1 й опубліковапого серійно у періодиці в 1924 p. $^{\text {j2: }}$

${ }^{50}$ Це переміщення самотнього героя в межах незрушного соціального ландшафту являється типовим для багатьох ранніх (анти-)колоніальних рманів.

Після короткої яскравої кар'єри радикального журналіста Марко був інтернований голландською колоніальною владою в Бовен Дігулі, 1)цюму з найперших у світі концентраційних таборів, глибоко в нетрях блліт на заході Нової Гвінеї. Там він і помер у 1932 р. після шести років у''язнення. Henri Chamber-Loir. "Mas Marco Kartodikromo (c. 1890-1932) ou L'Education Politique", p.208, in Litteratures contemporaines de l'Asie du S'ul-Est. Найновіший блискучий повноцінний опис кар'єри Марка можна .1айти в Takashi Shiraishi. 'An Age in Motion: Popular Radicalism in Java, 1912-1926, chapters 2-5 and 8.

" Переклад [на англійську] Пола Тікела. Див. Paul Tickell. Three Early Indonesian Short Stories by Mas Marco Kartodikromo (c. 1890-1932), p. 7. Виділено нами. 


\section{УЯВЛЕНІ СПІЛЬНОТИ}

Була сьома година в суботу вечором; молодь у Семаранзі ніколи не залишалася вдома суботніми вечорами. Однак цього разу нікого не було видно. Через цілоденну зливу дороги стали мокрими й дуже слизькими, тому всі сиділи по хатах.

Суботній ранок був для працівників крамничок і контор часом очікування - очікування дозвілля й радощів, які їм приносили вечірні прогулянки містом, та цього разу на них чекало розчарування - через апатію, викликану мерзенною погодою й жахливими дорогами в кампунгах. Головні шляхи, де завжди було повно руху, стежки, що звичайно кишіли людьми, тепер спорожніли. Час від часу можна було почути ляскіт батога, яким візник підганяв коней - або ж цокіт конячих копит, що долинав від екіпажів.

Семаранг обезлюднів. Сяйво гасових ліхтарів відбивалося від лискучого асфальту дороги. Часом це ясне сяйво тьмянішало, коли набігав вітерець зі сходу...

На видовженому плетеному кріслі сидів, читаючи газету, молодий чоловік. Він увесь поринув у читання. Гноді гнів, а іноді посмішки свідчили про його захоплення цією істоpiєю. Він гортав сторінки газети, сподіваючись, що не почуватиме себе таким нещасним. Зненацька натрапив на статтю під назвою:

\section{ДОБРОБУТ}

Жебрак-волоцюга захворів

і помер, замерзнувши на узбіччі дороги

Юнака зворушило це коротке повідомлення. Він уявив собі страждання бідолахи, коли той помирав, лежачи на узбіччі... Однієї миті його заполонила раптова злість. Пізніше він відчув жаль. Ше трохи згодом його гнів спрямувався на ту соціальну систему, що привела до такої злиденності, збагативши при цьому маленьку купку людей.

Тут, як і в "El Periquillo Sarniento", ми опиняємось у світі множини: крамнички, контори, екіпажі, кампунги й гасові ліхтарі. Як і у випадку з "Nol", ми-індонезійські-читачі відразу ж занурюємось у календарний час і знайомий нам ландшафт; можливо, дехто з нас і сам блукав цими "жахливими" дорогами Семарангу. Знову ж таки, самотній герой протиставляється соціопростору, ретельно змальованому в 


\section{КУЛЬТУРНІ КОРЕНІ}

загальиих деталях. Але є тут і щось нове: герої, жодиюг) разу не названий на ім'я, про якого автор каже “ияич моллодий чоловік”. Саме незграбність і літературна наївнісгь тексту иі підкреслюють несвідому “щирість” цього займенииконого прикметника. Ні в Марко, ні в його читачів це звертания пе викликає жодних застережень. Якшо у вишукано-гумористичній європейській літературі вісімнадцятого й дев'ятнадцятого віків використання тропу "напг герой” просто свідчило про авторську гру з (будь-яким) читачем, то “наш молодий чоловік” Марко, не в останню чергу через свою новизну, означає молодого чоловіка, що належить до сукупності читачів-індонезійців і, таким чином, імпліцитно до ембріопальної індонезійської “уявленої спільноти". Зауважмо, що Марко не відчуває жодної потреби уточнювати назву цієї спільноти: вона самозрозуміла. (Навіть, якби багатомовні колоніальні цензори-голландці могли потрапити до кола його читачів, вони не були б допушені до цієі “нашості", про що може свідчити хоча б той факт, що гнів молодого чоловіка спрямований на "ту", а не "нашу" соціальну систему.)

Нарешті, наявність уявленої спільноти підтверджується пашим подвійним прочитанням того, що читає молодий чоловік. Він не знаходить труп жебрака-волоцюги на узбіччі 'лизької семаранзької дороги, а уявляє його, прочитавши надруковану газету ${ }^{53}$. Иого також анітрохи не цікавить особа мертвого волоцюги: він думає про типового представника, а пе про персональне життя.

Досить доречним є те, що в "Semarang Hitam" газета виивляється вкрапленою в художнє тло оповідання, тобто вимислу, адже, якщо ми зараз звернемось до газети як продукту

${ }^{53}$ В 1924 р. близький приятель 1 політичний союзник Марко огублікував роман під назвою "Rasa Merdika" ["Відчуття свободи”]. ШомберІуар пише про героя цього роману (якого він помилково ототожнюе 3 Марко), шо "він не розуміє значення слова «соціалізм»: однак він відчуває, IIเо соціальний організм, який його оточує, є тяжко хворий, тому він має пютребу розширити свої горизонти двома засобами: подорожами й "итанням." "Мas Marco", p. 208. Виділено нами). Папуга зі сверблячкою ининився на Яві та, до того ж, у двадцятому сторіччі. 


\section{УЯВЛЕНІ СІІЛЬНОТИ}

культури, нас вразить ї̈ цілковита фіктивність. В чому полягає основна літературна умовність газети? Якщо б ми глянули на першу сторінку газети, скажімо, "Нью-Иорк Таймс", там ми могли б знайти повідомлення про радянських дисидентів, голод у Малі, страхітливе вбивство, переворот в Іраку, рідкісну палеонтологічну знахідку в Зімбабве й промову Міттерана. Чому ці всі події розташовані поруч? Що єднає іх між собою? Не просто примха. Проте очевидно, що більша частина їх відбувається цілком незалежно, й діючі особи не здогадуються про існування інших та про їхні наміри. Довільність їхнього включення й розташування (у пізнішому випуску замість Міттерана з'явиться репортаж про бейсбольний матч) свідчить про уявність зв'язку між ними.

Цей уявний зв' язок походить із двох побічно споріднених джерел. По-перше, це звичайний календарний збіг. Дата вгорі, єдина найважливіша емблема газети, подає найістотніший зв'язок - постійний і невпинний відрахунок однорідного, порожнього часу ${ }^{54}$. В межах цього часу "світ" впевнено просувається вперед. Ознака цього: якщо Малі, після дводенних репортажів про голод, зникає зі сторінок "Нью-Йорк Таймс" відразу на кілька місяців, читачі й на мить не припускають, що Малі щезло зі світу або голод винищив усіх його громадян. Белетристична газетна форма гарантує їм, що десь там "персонаж" Малі живе своїм непомітним життям, очікуючи наступної своєї появи в сюжеті.

Друге джерело уявного зв'язку полягає у відносинах між газетою як формою книги та ринком. Підраховано, по за сорок з лишком років між виданням Біблії Гутенберга i кінцем XV ст. в Європі було надруковано понад 20,000,000 книжок ${ }^{55}$. Між 1500 та 1600 рр. було виготовлено від

\footnotetext{
${ }^{54}$ Читаючи газету, начебто читаєш роман, автор якого зовсім не подбав про послідовність сюжету.

${ }_{55}$ Febvre and Martin. The Coming of the Book, p. 186. Це становить не менше 35,000 окремих видань, випущених, як мінімум, у 236 містах. Вже у 1480 р. друкарні існували більш ніж у 110 містах, з яких 50 знаходилися в нинішній Італії, 30 у Німеччині, 9 у Франції, по 8 у Голландії та Іспанії,
} 


\section{КУЛЬТУРНІ КОРЕНI}

$150,000,000$ до 200,000,000 екземплярів ${ }^{56}$. "Від самого по'атку... друкарські цехи більше нагадували сучасні майстерıі, ніж середньовічні монастирські скрипторії. У 1455 р. (Ууст і Шеффер вже провадили бізнесом, спрямованим на стандартизоване виробництво, а двадцятьма роками пізніше скрізь у всій [sic] Свропі діяли великі друкарські концерни" ${ }^{, 57}$. В якомусь смислі книга стала першим, у сучасному розуміниі, масово виготовленим промисловим товаром ${ }^{58}$. Що саме я маю на увазі, можна зрозуміти, порівнявши книгу з іншими ранніми промисловими виробами, такими, як текстиль, цегла 'и цукор. Адже ці товари вимірюються в точних кількостях (фунтах, партіях чи штуках). Фунт цукру є просто кількістю, зручною вагою, а не самостійним об'єктом. Книга, однак - і в цьому вона стає прототипом сучасних товарів тривалого користування - $є$ виразним самодостатнім об'єктом, що ідентично репродукується у великих масштабах 59 . Один фунт

I1) 5 у Бельгії та Швейцарії, 4 в Англії, 2 в Богемії та 1 в Польці. "Відтоді ıже можна було казати, по друкована книга в Європі стала предметом инального вжитку" (р. 182).

"' Ibid., p. 262. Автори зазначають, цо у шістнадцятому столітті книги нже були цілком доступні всім, хто вмів читати.

Велике видавництво Плантена з Антверпену контролювало, на ॥ю'гатку шістнадцятого сторіччя, 24 друкарні, де в кожному цеху працюІінло понад 100 робітників. Ibid., p. 125.

Це є одним із грунтовних моментів серед усіх химер Маршалла МакI'юен (див. Marshall McLuhan. Gutenberg Galaxy, p. 125). Можна додати, щ(), хоча книжковий ринок і був перевершений ринками інших товарів, llю стратегічна роль у потиренні ідей залишалась, однак, надзвичайно

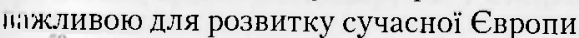

Принцип тут важливіпий від масштабу. До ХIX ст. тиражі були IIлносно скромними. Навіть перше видання Біблії Лютера, виняткового гістселера, вийшло тиражем усього лише 4,000 екземплярів. Незвично щ'ликий тираж першого видання “Енциклопедій” Дідро не перевищував 1,250 копій. Середній тираж у XVIII ст. становив менше ніж 2,000 книжок. (l'ebvre and Martin. The Coming of the Book, pp. 218-220). Водночас, книга иілжди відрізнялась від інших товарів тривалого користування своїм з ॥собхідності обмеженим ринком. Будь-хто з грошима може купувати мські автомобілі; лише читачі-чехи купуватимуть чеськомовні книжки. ॥ижче ми розглянемо значення цього розмежування. 


\section{УЯВЛЕНІ СПІЛЬНОТИ}

цукру слідує за іншим; кожна ж книга існує в самодостатності пустельника. (Не дивно, що вже в шістнадцятому столітті у таких центральних містах, як Париж, звичними стали бібліотеки, ці персональні зібрання масово виготовлених виробів ${ }^{\text {6i }}$.)

3 цієї перспективи газета являе собою просто “екстремальну форму” книги, яка продається у величезних кількостях, але користується ефемерною популярністю. Чи не можна сказати так: одноденні бестселери ${ }^{61}$ ? Старіння газети вже наступного дня після виходу в світ - цікаво, як один 3 найперших масово виготовлених виробів став прообразом швидкого старіння, притаманного сучасним товарам тривалого користування - саме тому, однак, і створює цей дивовижний масовий ритуал: практично одночасне споживання ("уявлювання") газети-як-літератури. Ми знаємо, що певні ранкові й вечірні випуски здебільшого будуть спожиті у визначені години саме того, а не іншого дня. (Порівняймо 3 цукром, вживання якого відбувається рівномірно й незалежно від певних годин; він може зіпсуватися, але не може втратити актуальність.) Сенс цього масового ритуалу - Гегель зауважував, що для сучасної людини газети відіграють роль замінника ранкових молитв - парадоксальний. Він відбувається в самотній тиші, в криївці власної голови . Проте кожен з причасників чудово усвідомлює, що здійснюваний ним ритуал одночасно відтворюється тисячами (або й мільйонами) інших, в існуванні яких він не сумнівається, але про ідентичність яких не має найменшого уявлення. До того ж, цей ритуал безперервно повторюється з інтервалами в півдня

${ }^{60}$ Білыше того, вже наприкінці п'ятнадцятого віку венеціанський видавець Альдо Манунціо започаткував портативне "кишенькове видання".

${ }^{61}$ На прикладі "Semarang Hitam" можна пересвідчитись, що раніше ці два різновиди бестселерів були тісніше пов'язані між собою, ніж нині. Дікенс також друкував серійно в масових газетах свої популярні романи.

62 “Друковані матеріали заохочували мовчазну прихильність до справ, оборонців яких неможливо було віднайти в жодній парафії, бо вони звертались до невидимої публіки звіддаля". Elizabeth L. Eisenstein. "Some Conjectures about the Impact of Printing on Western Society and Thought", Journal of Modern History, 40: 1 (March 1968), p. 42. 


\section{КУЛЬТУРНI КОРЕНI}

або день згідно з календарем. Чи можна уявити собі більш искравий образ секулярної, історично захронометрованої уявної спільноти ? Водночас читач газети, спостерігаючи, як відвідувачі перукарні, метро або сусіди по житлу пере1'лядають ідентичні копії його газети, постійно переконується 13 тому, що уявний світ зримо закорінений у щоденному житті. Як у випадку з "Noli Me Taпgere", літературний вими'сл непомітно й упевнено просочується в реальність, творячи ту дивовижну впевненість анонімної спільності, що $є$ ознакою сучасних націй.

Перш ніж перейти до обговорення специфічних першоиричин націоналізму, варто було б підсумувати основні тверцження, висловлені досі. По суті, я доводив, що сама можлииість уявлювання нації історично з'явилася там і тоді, коли гри дуже давні фундаментальні культурні концепції втратили свою аксіоматичну владу над людськими умами. Першою з них була ідея про те, що тільки певна книжна мова забезиечувала привілейований доступ до онтологічної істини ‘ме тому, що мова була невіддільною частиною цієї істини. Ця ідея дала життя великим трансконтинентальним соліларностям християнського, ісламського та інших світів. Друюю була віра в те, що суспільство природнім чином органіюване навколо і в підпорядкуванні до верховних центрів монархів, які стоять осторонь решти людських істот, і чиє шравління $€$ формою космологічного (божественного) завіту. ॥юдські лояльності були необхідно ієрархічними й доцентювими, адже володар, як і сакральний текст, був фокусом

${ }^{63}$ Пишучи про стосунки між майновою анархією суспільства середI11,ого класу та абстрактним політичним державопорядком, Нейрн зауніжує, що "представницький механізм перетворював реальну класову "І'рівність у абстрактний егалітаризм громадян, індивідуальний егоїзм у и'злике колективне волевиявлення, загрозу хаосу в нову державну легі"нмпість". (The Break-up of Britain, p. 24). Безсумнівно. Проте представпицький механізм (вибори?) є рідкісним і мінливим святом. Мені зда- нся, що покоління безликого волевиявлення найкраще розкривається y иегулярному шоденному уявлюванні життя. 


\section{УЯВЛЕНІ СПІЛЬНОТИ}

доступу до буття й невід'ємною його частиною. Третьою була концепція темпоральності, в якій космологія та історія були нерозрізнимі, а першопричини світу й людини сутнісно ідентичні. Разом ці ідеї міцно вкорінювали життя людей у самій природі речей, надаючи певний смисл фатальностям щоденного існування (перш за все смерті, втратам і залежності) та пропонуючи, різними засобами, визволення від них.

Повільний, нерівномірний занепад цих взаємопов'язаних очевидностей - спочатку в Західній Європі, а згодом повсюди - під впливом економічних змін, "відкриттів" (соціальних і наукових) та поширення дедалі швидших засобів комунікації, вбив глибокий клин між космологією й історією. Не дивно отже, що йшли пошуки, так би мовити, нового способу осмислено поєднати разом солідарність, владу й час. Мабуть, ніщо так не прискорило ці попуки й не зробило їх пліднішими, ніж розвиток капіталістичного друкарства, шо надав можливість все швидше зростаючій кількості людей думати про себе й співвідносити себе 3 іншими у кардинально новий спосіб. 


\section{Витоки національної свідомості}

Якщо розвиток друкарства-як-товару і $€$ визначальним ц.я цілого покоління нових ідей про одночасність, цей виснощк лише констатує, що виникнення спільнот "горизонтально-секулярного, поперечно-часового" типу стає можлипим. Чому, в межах цього тину, такої популярності набула саме нація? Тут, безперечно, задіяні складні й різноманітні 中актори. Але можна висунути вагомі аргументи на користь ширішального значення капіталізму.

Як уже зазначалось, до 1500 р. було надруковано пришаймні 20,000,000 книжок , що сигналізувало про поча' ок, ia словами Бенджаміна, "ери механічного репродукування". Тоді як мудрість манускриптів була прихованою й недоступююю, друковані знання можна було відтворювати й поширюнати . За підрахунками Февра й Мартена, до 1600 р. було нже, мабуть, видано близько 200,000,000 томів, тому й не

1 Населення тієї частини Європи, де було вже знане друкарство, палічувало тоді близько 100,000,000 осіб. Febvre and Martin. The Coming of the Book, pp. 248-249.

" Показовими є “Подорожі" Марко Поло, шо залишалися здебільшого невідомими, поки не були надруковані вперше в 1559 p. Polo. Travels, ю. XIII. 
дивно, що друкарство, на думку Френсіса Бекона, змінило "вигляд і стан світу".

Книгодрукування, ця одна з найперших форм капіталістичного підприємництва, відчуло властивий капіталізму взагалі невгамовний пошук нових ринків. Першодрукарі відкрили філії по всій Європі: “таким чином було створено справжній видавничий "інтернаціонал", який ігнорував національні [sic] кордони" ${ }^{\prime 4}$. До того ж, час між 1500 і 1550 pp. став періодом виняткового європейського процвітання, і видавці теж скористались із загального пожвавлення. "Більш ніж будь-коли" це була "велика індустрія, контрольована заможніми капіталістами". Природньо, що "книготорговці перш за все дбали про отримання прибутку й продаж свого товару, i відповідно в першу чергу розшукували ті твори, якими цікавилась якомога більша кількість іхніх сучасників".

Початково ринок складався з освічених європейців, поширеного, але тонкого прошарку латиномовних читачів. Насичення цього ринку відбулося протягом приблизно півтори сотні років. Характерним для латини - попри ії сакральність - було те, що вона вживалася двомовними читачами. Мало хто розмовляв нею від народження, і ще менше, треба гадати, бачило на латині сни. В шістнадцятому столітті частка двомовних людей в населенні Європи була досить малою; цілком імовірно, не більшою ніж в населенні землі сьогодні й - незважаючи на пролетарський інтернаціоналізм - у найближчі століття. Тоді, як і нині, людство складалося переважно з моноглотів. За логікою капіталізму,

\footnotetext{
${ }^{3}$ Цитата наведена в Eisenstein. “Soше Conjectures", p.56.

${ }^{4}$ Febvre and Martin. The Coming of the Book, p. 122. (В оригіналі, однак, йдеться просто про "par-dessus les frontieres". L'Apparition, p. 184.)

5 Ibid., p. 187. В оригіналі йдеться радше про "puissants" (могутніх), ніж про “заможніх" капіталістів. L'Apparition, р. 281.

6 "Відповідно, запровадження друкарства було в цьому відношенні етапом на шляху до нашого сучасного суспільства масового споживання й стандартизаціï”. Ibid., pp. 259-260. (В оригіналі говориться про “ипе civilisation de masse et de stardardisation", що, мабуть, краще передати як “стандартизована, масова цивілізація”. L'Apparition, р. 394.)
} 


\section{ВИТОКИ НАЦІОНАЛЬНОІ̆ СВІДОМОСТІ}

ұ ким чином, після насичення елітарного латиномовного пшкку настала черга потенційно величезних ринків, пред- пилених одномовними масами. Безумовно, Контрреформіıція сприяла тимчасовому відродженню латиномовного мигодрукування, проте на середину сімнадцятого сторіччя щиї рух переживав занепад, а бібліотеки ревних католиків щю)енасичуються. Тим часом, загальноєвропейський брак 1рюшей примушував друкарів все більше подумувати про (1))гівлю дешевими виданнями на розмовних мовах .

Революційний перехід під впливом капіталізму до розмเювних мов отримав додатковий імпульс від трьох побічних |икторів, два з яких безпосередньо сприяли піднесенню піціональної свідомості. Першим i, зрештою, найменш важIIıим була зміна в характері самої латини. Завдяки трудам гуманістів по відродженню дохристиянської античної літерілтури й поширенню її засобами друкарського ринку, в сереинищі трансєвропейської інтелігенції помітно відновився ıмік до вишуканих стилістичних здобутків древніх. Латина, пкюю вони тепер прагнули писати, ставала дедалі подібнішою ли стилю Цицерона й, тим самим, усе віддаленішою від цериюњного й буденного життя. Таким чином вона набула езотеричності, цілком відмінної від церковної латини в середньоi!' יі. Адже давніша латина була таємничою не завдяки своїм ıмам чи стилю, а просто тому, що вона взагалі була писаною, июбто завдяки їі статусу як тексту. Тепер вона ставала таємшю через те, що саме було написано, через мову як таку.

Другим фактором був вплив Реформації, яка сама завдячувала значною часткою свого успіху капіталістичному друиіґсств. Раніше, до ери друкарства, Рим з легкістю здобував шюремоги над єрессю в Західній Європі, тому що володів крапцими від своїх опонентів внутрішніми лініями комунікацій. А.ле коли в 1517 р. Мартін Лютер прибив свої тези на дверях «інлички у Віттенберзі, їх віддрукували в перекладі на иімецьку, i “через 15 днів [іх можна було] бачити в кожному

\footnotetext{
${ }^{7}$ Ibid., p. 195.
} 


\section{УЯВЛЕНІ СПІЛЬНОТИ}

куточку країни"в. Протягом двох десятиліть з 1520 по 1540 pр. німецькою мовою було опубліковано втричі більше книжок, ніж за період з 1500 по 1520 рр. - дивовижна зміна, в якій Лютер зіграв абсолютно виняткову роль. Його праці становили не менш третини від $y$ cix німецькомовних книжок, проданих між 1518 i 1525 pp. Між 1522 і 1546 pp. з'явилося 430 видань (повних або часткових) його перекладів Біблії. "Вперше ми тут маємо справді масового читача й усім доступну популярну літературу" Фактично, Лютер став першим справжнім автором бестселерів. Або, інакше кажучи, першим письменником, який міг "продавати” свої новi книжки завдяки власному імені ${ }^{2}$.

Слідом за.Лютером невдовзі вирушили й інші, започаткувавши колосальну релігійно-пропагандистську війну, що лютувала в Свропі протягом наступного століття. В цій титанічній “битві за людські уми” протестантизм завжди принципово знаходився у наступі саме тому, що знав, як використати зростаючий ринок вернакулярних видань, створений капіталізмом, тоді як контрреформація захищала цитадель латини. Символом цього став Index Librorum Prohibitorum Ватикану - який не мав протестантського відповідника - новий ресстр, необхідність у якому виникла через саму кількість друкованих підривних матеріалів. Ніщо так не передає відчуття цієї ментальності облоги, як панічна заборона 1535 р. Франциском I друкувати в його королівстві будь-які книжки - під страхом смерті через повішення! Причиною як самої заборони, так і її нездійснимості було те, що східні кордони королівства були вже оточені протестантськими державами й містами, з яких текла ріка контрабандної друкованої продукції. Візьмімо хоча 6 Женеву

${ }^{8}$ Ibid., pp. 289-290.

${ }^{9}$ Ibid., pp. 291-295.

3 цієї точки зору це був просто крок до ситуації, яка виникла у Франції XVII ст., коли Корнель, Мольер і Лафонтен могли напряму продавати рукописи своїх трагедій і комедій видавцям, які вважали іх чудовими інвестиціями з огляду на ринкову репутацію авторів. Ibid., p. 161. 


\section{ВИТОКИ НАЦІОНАЛЬНОÏ СВІДОМОСТІ}

'» ин Кальвіна: між 1533 і 1540 рр. там було опубліковано ІІпик 42 окремих видання, а вже між 1550 і 1564 рр. їх число үкжло до 527, причому в останні з цих років не менше 40 дру1..ркюких машин працювали понаднормово ${ }^{11}$.

Союз протестантизму й капіталістичного друкарства, виищ) стовуючи дешеві популярні видання, швидко створив i11ıу читацьку публіку - не в останню чергу серед торговців I жиок, котрі, як правило, майже (або цілком) не знали латиIIII - і водночас мобілізував їх для політично-релігійних цілей. I I'минучим було розхитування не лише церковних основ. Той l.ıки землетрус породив перші значні європейські не-динасІІІ'иі й не-міські держави Голландської Республіки та пури1.11'ької Співдружності. (Паніка Франциска I була викликана III' 'ілььки релігійними, але й політичними причинами.)

1'ретім фактором було повільне, географічно нерівномірIII. ॥оширення окремих народних мов як інструментів адміıштративної централізації деким з майбутніх абсолютних м⿻архів. Тут варто згадати, що універсальність латинської мини в середньовічній Західній Європі ніколи не означала уиіверсальної політичної системи. Повчальним є контраст І імиерським Китаєм, де сфери впливу ієрогліфів і бюрокраIII мандаринів в цілому збігалися. Фактично, політична риздрібленість Західної Європи після розпаду Західної ІмпеI'і' означала, що жодний суверен не міг монополізувати латиıу иї зробити з неї "його й тільки його“державну мову, й таи.м чином релігійний авторитет латинської мови ніколи не міиз справжнього політичного відповідника.

Виникнення адміністративних народних мов передувало ик лрукарському, так і релігійному переворотам XVI ст., тому ॥ має розглядатися (принаймні, спочатку) як незалежний | 'актор ерозії сакральної уявленої спільноти. У той же час, ıіцо не вказує, що в основі цієї вернакуляризації (де вона мідбувалася), лежали якісь глибинні ідеологічні, не говорячи иже про протонаціональні, імпульси. Випадок з “Англією" -

${ }^{11}$ Ibid., pp. 310-315. 
на північно-західній периферії латиномовної Свропи - $є$ в цьому відношенні особливо показовим. До норманського завоювання, мовою королівського двору, літературною іi адміністративною, була англосаксонська. Протягом наступних півтора століття практично всі королівські документи складалися латиною. Приблизно між 1200 і 1350 pp. ця державна латина була витіснена норманським діалектом французької мови. Тим часом, поступове злиття цієї мови чужоземного правлячого класу з англосаксонською підлеглого населення утворило ранньоанглійську мову. Це злиття дало змогу новій мові, в свою чергу, стати після 1362 р. мовою двору, а також сприяло відкриттю Парламенту. В 1382 р. з'явилася вернакулярна рикописна Біблія Вікліфа ${ }^{12}$. Важливо пам'ятати, що все це були “державні", а не "національні" мови; і шо держава, про яку йдеться, в різні часи охоплювала собою не тільки сьогоднішні Англію й Уельс, але й також частини Ірландії, Шотландії та Франціі. Очевидно, що значні прошгарки підлеглих народів не знали цілком, або погано володіли латиною, норманським діалектом чи ранньоанглійською мовою ${ }^{13}$. Ще через більш ніж століття після політичної інтронізації ранньоанглійської мови влада Лондона буде виметена 3 “Франціiі".

На берегах Сени мав місце тотожний розвиток, хоч і дещо повільніше. Як зауважує глузливо Блок, “французька, тобто мова, якій, з тих пір як її вважали просто зіпсутою латиною, довелося протягом кількох віків доводити свої літературні достоїнства" ", стала офіційною мовою правосуддя лише в 1539 р., коли Франциск I видав Віллер-Коттереський Указ ${ }^{15}$. В інших династичних державах латинська мова протривала

${ }^{12}$ Seton-Watson. Nations and States, pp. 28-29; Bloch. Feudal Society, I, p. 75.

${ }^{13}$ Не варто гадати, що адміністративна уніфікація вернакулярів була відразу ж або повністю досягнута. Малоймовірно, щоб адміністрування провінції Гієнь, керованої з Лондона, коли-небудь велося переважно ранньоанглійською мовою.

${ }_{14}$ Bloch. Feudal Society, I, p. 98.

${ }^{15}$ Seton-Watson. Nations and States, p. 48. 


\section{ВИТОКИ НАЦІОНАЛЬНОЇ СВІДОМОСТІ}

IIічио довше - під Габсбургами, скажімо, аж до дев'ят11.циятого сторіччя. Ще в інших верх узяли “чужі" народні ıuıи: у XVIII ст. при дворі Романових звучала французька II пімецька ${ }^{16}$.

В кожному випадку “вибір” мови видається поступовим, шгусвідомленим, прагматичним, щоб не сказати довільним ю. юком. Цим він цілковито відрізняється від свідомої мовної ו1.літики, яку проводили династичні правителі XIX ст., интовхнувшися з ростом ворожого їм мовного націоналізму. 1.(1н13. далі розділ 6.) Найочевидніша відмінність полягала в ıму, що старі адміністративні мови тільки ними й були, пाккористовуючись офіціозом і для офіціозу, задля його п!утрішньої зручності. Не виникало й думки про системаII'וне нав'язування мови різним народам, що підлягали Iшнастичному правителю . Тим не менше, набуття цими піродними говірками статусу мови-при-владі, коли, в певному сенсі, вони ставали суперниками латини (французька в IIıрижі, [ранньо] англійська в Лондоні), також сприяло занепіцу уявленої спільноти християнства.

у кінцевому підсумку, схоже, що езотеризація латинської мюви, Реформація й некерований розвиток адміністративних ш'рнакулярних мов у контексті нашої теми важливі переду. ім в негативному смислі - своїм внеском у занепад латини. І Цілком можливо припустити виникнення нових уявлених ॥аціональних спільнот і без будь-якого з цих факторів, навіть без них усіх. Що дійсно зробило, в позитивному плані, можıвим уявити нові спільноти, була напіввипадкова, але вибухююодібна взаємодія між системою виробництва й виробничих ıіццосин (капіталізмом), технологією комунікації (друком) i исуникненним лінгвістичним розмаіттям людства ${ }^{18}$.

${ }^{16}$ Ibid., p. 83.

${ }^{17}$ Відповідне підтвердження цієї точки зору надає нам Франциск I, який, як ми бачили, повністю заборонив друкування книжок у 1535 p., а 'ютирма роками пізніше зробив французьку мовою свого двору!

Це був не перший такий “випадок”. Февр і Мартен зазначають, шо

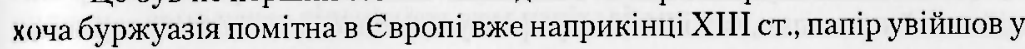




\section{УЯВЛЕНІ СПІЛЬНОТИ}

Елемент визначеності є надзвичайно важливим. Адже, на які надлюдські подвиги не був би здатний капіталізм, у смерті й мові він знайшов собі двох достойних суперників ${ }^{19}$. Окремі мови можуть вигасати чи бути знищеними, але загальна мовна уніфікація людства не можлива. Однак ці мовні бар'єри історично були маловажливими, поки капіталізм і друкарство не створили масову мономовну читацьку публіку.

Хоча пам'ятати про ідею визначеності в смислі загальної умови неподоланної лінгвістичної різноманітності важливо, помилкою було 6 ототожнювати таку рокованість з тим спільним елементом націоналістичних ідеологій, який підкреслює примордіальну визначеність певних мов та їх зв'язку із певними територіальними одиницями. Істотним є взаємодія між данністю, технологією й капіталізмом. В Європі перед зародженням друкарства, як, зрозуміло, й деінде в світі, строкатість розмовних мов, тих мов, що для своїх носіїв складали (і складають) саму тканину життя, була безмежною. Настільки, що коли 6 капіталістичне друкарство схотіло використати кожний потенційний народномовний ринок, він залишився 6 досить дрібним капіталізмом. Але з усіх цих говірок можливо було сконструювати, з певними обмеженнями, значно меншу кількість мов, придатних для друку. Вже сама довільність будь-якої знакової системи передачі звуків полегшувала процес монтажу ${ }^{2-}$. (Водночас, чим ідео-

загальне користування лише наприкінці XIV cr. Тільки завдяки гладенькій рівній поверхні паперу стало можливим масове репродукування текстів і малюнків - і на це пішло ше сімдесят п'ять років. Проте папјр не був європейським винаходом. Він прийшов сюди з іншої історії - 3 китайської - через мусульманський світ. The Coming of the Book, pp. 22, 30 and 45 .

${ }_{19}$ Ми й досі не маємо гігантських багатонаціональних компаній у видавничому світі.

${ }^{20}$ Для корисної дискусії на цю тему див. S. H. Steiпberg. Five Hundred Years of Printing, chapter 5. Те, що знак "ough" по-різному вимовляється у словах "although", "bough", "lough", "rough", "cough" і "hiccough", вказує як на ідіолектичну різноманітність, з якої виник стандартний тепер англійський правопис, так і на ідеографічну якість остаточного продукту. 


\section{ВИТОКИ НАЦІОНАЛЬНОІ̆ СВІДОМОСТІ}

чрафічніші знаки, тим ширша потенційна зона конструюшання. Тут можна помітити щось на зразок нисхідної ієрархії піл алгебри через китайську й англійську мови до регулярних ('илабічних азбук французької та індонезійської мов.) Ніщо І:Ік не сприяло "монтажу" споріднених говірок, як капіталізм, що у межах, дозволених граматикою й синтаксисом, створюзав механічно репродуковані книжні мови, придатні до пюнирення засобами ринку ${ }^{31}$.

Ці друковані мови заклали підгрунтя національної свідомості трьома різними шляхами. Перш за все, вони створили 1 циний простір взаємообміну й комунікації, нижче від латиIII, але вище розмовних діалектів. Носії величезної кількості |ранцузьких, англійських чи іспанських мов, з труднощами . мілли змогу порозумітися через друк і папір. Упродовж цього ॥р)цесу вони поступово доходили до усвідомлення існувань ситень тисяч, навіть мільйонів людей у своєму власному мовному просторі, а водночас до того, що тільжи ці сотні ІІІяч чи мільйонів до нього належать. Ці читачі, пов'язані між собою за допомогою друку, формували, у своїй секуляр11іi, специфічній, видимій невидимості, ембріон національно уялвленої спільноти.

По-друге, капіталістичне друкарство надало мові нової "табільності, яка, в кінцевому підсумку, допомогла вибудунати центральний для суб'єктивної ідеї нації образ її староцінвності. Як нам нагадують Февр і Мартен, друкована книга мала незмінний вигляд і здатність до практично безконечиого відтворювання в часі й у просторі. Вона вже більше не илежала від індивідуалістичних та "несвідомо осучасню"чих" звичок монастирських переписувачів. Таким чином,

\footnotetext{
${ }^{21}$ Я навмисно кажу "ніщо так не сприяло... як капіталізм". I Штайнберг, І Аїзенштайн наблизились до обожнення “друку” як геніального втілення иняітньої історії. Февр і Мартен ніколи не забували, що за "друком“ стояли лрукарі й видавництва. В цьому контексті варто пам'ятати, що, хоча друк

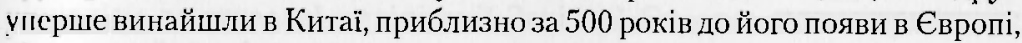
iin не справив тоді жодного значного, вже не кажучи революційного, шиливу - саме через відсутність там капіталізму.
} 


\section{УЯВЛЕНІ СПІЛЬНОТИ}

якщо французька мова дванадцятого сторіччя суттєво відрізнялася від тієї, якою писав Війон у п'ятнадцятому, темп змін у шістнадцятому віці значно уповільнився. "Вже на XVII ст. європейські мови в цілому набули своїх сучасних форм"22. Інакше кажучи, ось уже протягом трьох століть ці стабілізовані друковані мови лише шліфуються; слова наших предків із сімнадцятого сторіччя залишаються нам доступними на відміну від Війона, котрий міг не розуміти своїх попередників з дванадцятого віку.

По-третє, капіталістичне друкарство створило мови-привладі, які різнилися від давніших адміністративних вернакулярних мов. Певні діалекти неминуче ставали "ближчими" для відповідних друкованих мов і домінували в їх остаточних формах. Менш щасливі кузени цих діалектів, також здатні до асиміляції з новою друкованою мовою, програли справу головним чином тому, що їм не вдалося (або вдалося частково) наполягти на власній друкованій формі. "Північнозахідна німецька" перетворилась у "Platt Deutsch", здебільшого розмовну, а отже нелітературну німецьку говірку, тому що була здатна до асиміляції з друкованою німецькою мовою на відміну від богемського діалекту розмовної чеської. Верхньо-німецька, королівська англійська, а згодом центральна тайська, були відповідно піднесені на нову політикокультурну висоту. (Звідси й боротьба деяких “другорядних" націй у Європі кінця $\mathrm{XX}$ ст. за зміну свого підлеглого становища через стабільний доступ до друку й радіо.)

Лишається тільки підкреслити, що на самому початку стабілізація друкованих мов і диференціація їхнього статусу були здебільшого неусвідомленими процесами, що виникали в результаті стрімкої взаємодії між капіталізмом, технологією й людською багатомовністю. Але, як це часто траплялося в історії націоналізму, раз утворившись, вони могли ставати формальними моделями для наслідування, а там, де

${ }^{22}$ The Coming of the Book, p. 319. Порівн. L'Apparition, p. 477: "Au XVII siecle, les langues nationales apparaissent un peu partout cristallisees". 


\section{ВИТОКИ НАЦІОНАЛЬНОI СВІДОМОСТІ}

11. було доцільним, для свідомого використання в дусі Мак'яiш.лі. Сьогодні уряд Таїланду активно перешкоджає спро1.1м іноземних місіонерів створити для меншин 3 гірських 11ємен власні системи транскрипції та сприяти поширенню публікацій на їхніх мовах: той самий уряд байдуже в цілому 1 ниниться до того, як говорять ці меншини. Особливо поw1:1ьною $\epsilon$ доля тюркомовних народностей в районах, роз1.111ованих у нинішніх Туреччині, Ірані, Іраку й СРСР. 1 імсйство розмовних мов, яке колись було зрозумілим скрізь 1.І1дяки арабській орфографії, втратило цю єдність в реуу.льтаті свідомих маніпуляцій. Щоб піднести тюркську ш.1іональну свідомість Туреччини коштом будь-яких ширшик ісламських ідентифікацій, Ататюрк нав'язав обов'яз1 ищий латинський шрифт ${ }^{23}$. Радянський уряд наслідував цей "юиклад, спочатку антиісламською, антиперською примусоI11ю латинізацією, а потім, у сталінські 1930-ті, примусово 1.11ровадивши русифікаторську кирилицю ${ }^{24}$.

Ми можемо підсумувати висновки з попереднього огляду, 1 เюрджуючи, що зіткнення капіталізму й друкарської техi11.логії з історично успадкованою строкатістю людських мов 1 11.а вже самими своїми базовими структурами підготувала . жюу для сучасної нації. Потенційний обсяг цих спільнот буњ обмежений їх походженням i, водночас, мав не більш ніж пр!падкове відношення до існуючих політичних кордонів ( икі, в цілому, окреслювали максимальні здобутки династичших експансій).

Однак цілком очевидно, що хоч нині майже всі сучасні пації - й національні держави теж - мають "національні пуковані мови”, багато з них користуються спільною мовою,

${ }^{23}$ Hans Kohn. The Age of Nationalism, p. 108. Справедливо, мабуть, буде iюціти, що таким чином Ататюрк сподівався наблизити турецький напюналізм до сучасної цивілізації Західної Європи, що використовує 1.'11нский шрифт.

Seton-Watson. Nations and States, p. 317. 


\section{УЯВЛЕНІ СПІЛЬНОТИ}

тоді як в інших лише незначна частка населення "користується" національною мовою в розмовах чи на папері. Національні держави іспаномовної Америки, або ті, що належать до "англосаксонської групи", є показовим прикладом першого з цих варіантів; чимало постколоніальних держав, особливо в Африці - другого. Інакше кажучи, конкретні утворення, що ними є сучасні національні держави, у жодному разі не $€$ ізоморфними встановленому простору тієї чи іншої друкованої мови. ЦЦоб зрозуміти цю "незалежну залежність“ між друкованими мовами, національною свідомістю й національними державами, необхідно звернутися до великої групи нових політичних утворень, що виникли в Західній півкулі між 1776 і 1838 рр., цілком усвідомлено визначивши себе націями i, за винятком Бразилії, (нединастичними) республіками. Адже вони не тільки були історично першими державами такого типу на світовій сцені, й тому першими реальними моделями того, як мали б “виглядати" подібні держави, але й сама їх кількість і одночасність появи на світ дають нам плідний грунт для компаративного дослідження. 


\section{Креольські першовідкривачі}

Нові американські держави кінця вісімнадцятого й по'атку дев'ятнадцятого сторіч особливо цікаві тим, що їх майже неможливо пояснити за допомогою тих двох факторів, икі, мабуть, завдяки легкості, з якою їх виводили з націоналістичних рухів Європи середини цього століття, домінували " більшості європоцентричих теорій походження націоналізму.

Перш за все, кого 6 ми не розглядали - Бразилію, США 'и колишні іспанські колонії - мова не була тим елементом, що відрізняв ї від відповідних імперських метрополій. Усі вони, включаючи США, були креольськими державами, (ぬормованими й керованими людьми, які поділяли спільну мову й спільне походження з тими, проти кого боролися Справді, не буде перебілыпенням сказати, що питання про мову ніколи не ставилось у цих ранніх змаганнях за націопальне визволення.

По-друге, $є$ вагомі підстави сумніватися у придатності для більшої частини Західної півкулі в інших відношеннях переконливої тези Нейрна про те, що:

\footnotetext{
${ }^{1}$ Креол (Criollo) - особа чисто (принаймні теоретично) європейського ноходження, але народжена на американському континенті (а згідно з останніми доповненнями, будь-де поза Європою).
} 
Виникнення націоналізму у виразно модерному сенсі було пов'язане з політичним хрещенням нижчих класів... Хоча й ворожі часом демократії націоналістичні рухи незмінно були популістськими за формою і прагнули залучати нижчі класи до політичного життя. У найбільш типовій версії це набирало форми лідерства невгамовного середнього класу та інтелігенції, що намагалися скерувати енергії народних мас на підтримку нових держав .

Принаймні в Південній та Центральній Америці, “середні класи” у європейському розумінні були ще цілком незначними наприкінці вісімнадцятого століття. Майже не існувало й інтелігенції. Адже "в ті спокійні колоніальні дні величавий і бундючний ритм чоловічого життя зрідка порушувався читанням" ${ }^{\prime 2}$ Як ми вже знаємо, перший іспано-американський роман був опублікований лише 1816 року, значно пізніше, ніж вибухли війни за незалежність. Все свідчить про те, що лідерство належало крупним землевласникам в союзі 3 трохи менш чисельними торгівцями та “людьми професій“ (юристами, військовими, місцевими і провінційними чиновниками").

Навряд чи йдеться про “залучення нижчих класів до політичного життя": одним із ключових факторів, що з самого початку живив бажання до незалежності від Мадрида в таких важливих випадках, як Венесуела, Мексика й Перу, був cmpax перед загрозою політичної мобілізації "нижчого класу": бажання попередити бунти індіанців або негріврабів . (Цей страх тільки збільшився, коли гегелівський

${ }^{2}$ The Break-up of Britain, p. 41.

${ }^{3}$ Gerhard Masur. Simon Bolivar, p. 17.

${ }^{4}$ Lynch. The Spanish-American Revolutions, pp. 14-17 and passim. Цi пропорції виникли завдяки тому, що виконання важливітих комерційних i адміністративних функцій було здебільшого монополізовано корінними іспанцями, тоді як землевласництво було цілковито відкритим для креолів.

5 В цьому смислі це є чіткі аналогії з бурським націоналізмом наступного століття. 


\section{КРЕОЛЬСЬКІ ПЕРШОВІДКРИВАЧІ}

"міністр Світового Духу" захопив у 1808 р. Іспанію, позбавивши таким чином креолів усякої надії на військову підц иимку з півострова в разі необхідності.) В Перу ще були гиіжими згадки про велику жакерію під проводом Тупака Амару (1740-1781) ${ }^{6}$. У 1791 р. Туссен Лувертюр очолив повгтання чорних рабів, що привело до появи в 1804 р. другої пезалежної республіки в Західній півкулі - й нажахало могутніх плантаторів-рабовласників з Венесуели ${ }^{7}$. Коли 1789 юоку в Мадриді вийнов новий, гуманніший закон про раб'“'во, що детально визначав права й обов'язки власників i |абів, “креоли не визнали державного втручання, мотивуњавши це схильністю рабів до розпусти й самостійності [!] та тим, що вони конче потрібні для розвитку економіки. $\checkmark$ Венесуелі - та й скрізь, фактично, в іспанських колоніях Карибського моря - плантатори чинили закону опір і 1794 року домоглися тимчасового припинення його дії,". Визволитель Болівар сам колись висловив думку про те, що негритянський бунт "в тисячу разів гірший від іспанського "торгнення". Не можна також забувати, що багато лідерів руху за незалежність Тринадщяти Колоній були земельними магнатами-рабовласниками. Томас Джефферсон, приміром, палежав до вірджинських плантаторів, яких у 1770-х pp. обурив указ губернатора-лояліста про звільнення рабів, шо итекли від тих своїх власників, котрі готували заколот ${ }^{10}$. І Гоказовим $€$ й те, що однією з причин успішного повернення Мадридом свого контролю над Венесуелою у $1814-1816$ pp. і втримування ним віддаленого Кіто до 1820 р. було в першому випадку завоювання підтримки рабів, а в другому -

\footnotetext{
${ }^{6}$ Мабуть, варте уваги те, що Тупак Амару повністю не відмовлявся иід своєї лояльності іспанському королю. Він та його послідовники (здебільного індіанці, хоча й траплялися білі й метиси) повстали в гніві ироти режиму в Лiмi. Masur. Bolivar, p. 24.

Seton-Watson. Nations and States, p. 201.

${ }^{8}$ Lynch. The Spanish-American Revolutions, p. 192.

9 Ibid., p. 224

${ }^{10}$ Edward S. Morgan. "The Heart of Jefferson", The New York Review of Books, August 17, 1978, p. 2.
} 


\section{УЯВЛЕНІ СПІЛЬНОТИ}

індіанців у боротьбі з повсталими креолами ${ }^{11}$. До того ж, тривалість континентальної боротьби проти Іспанії, на той час вже другоряцної європейської держави, котра сама нещодавно була підкорена, свідчить про певну “соціальну поверховість" цих латиноамериканських рухів за незалежність.

Проте це були таки рухи за національну незалежність. Болівар змінив свою думку про рабів ${ }^{12}$, а його соратник Сан Мартін у 1821 р. видав указ про те, що "в майбутньому корінних мешканців не називатимуть індіанцями або тубільцями; всі вони є діти й громадяни Перу, тобто - перуанці" . (Можна додати: незважаючи на те, що капіталістичне друкарство ще не дійшло до цих неписьменних народів.)

Тут, отже, криється загадка: чому саме креольські спільноти так рано виробили ідею своєї належності до нації - набагато раніше від більшої частини Єеропи? Чому в цих колоніальних провінціях, населення яких складалося переважно з пригноблених неіспаномовних народностей, з'явилися креоли, які свідомо переосмислювали це населення як співгромадян? А Іспанію ${ }^{14}$, з якою їх стільки пов'язувало, як ворожого чужака? Чому Іспано-Американська Імперія, яка спокійно проіснувала впродовж мало не трьох сторіч, зненацька розвалилась на вісімнадцять окремих держав?

${ }^{11}$ Masur. Bolivar, p. 207; Lynch. The Spanish-American Revolutions, p. 237.

${ }^{12}$ Не без певних вагань. Він звільнив своїх власних рабів невдовзі після проголошення незалежної Венесуели 1810 року. Після втечі до Гаїті 1816 року він отримав військову допомогу від президента Александра Петіона в обмін на обіцянку ліквідувати рабство на всіх звільнених територіях. Обіцянку було виконано в Каракасі у 1818 р. - але слід пам'ятати, шо Мадрид частково досяг своїх успіхів у Венесуелі між 1814 1816 рр. завдяки сөоєму рішенню про визволення лояльних рабів. Коли Болівар став президентом Великої Колумбії (Венесуели, Нової Гранади й Еквадору) в 1821 р., він домігся прийняття Конгресом закону про звільнення невільницьких синів. Він "не вимагав від Конгресу повної ліквідації рабства, бо не хотів викликати обурення великих землевласників". Masur. Bolvvar, pp. 125, 206-207, 329 and 388.

${ }_{13}$ Lynch. The Spanish-American Revolutions, p. 276. Виділено нами.

14 Анахронізм. У вісімнадцятому столітті ще було заведено вживати термін Las Espanas [Іспаніï], а не España [Іспанія]. Seton Watson. Nations and States, p. 53. 
Два фактори найчастіше залучаються для пояснення: посилення контролю з боку Мадрида і розповсюдження ліберальних просвітницьких ідей у другій половині вісімнадцятого сторіччя. Безсумнівно, що політика, яку вправно здійс॥ював "просвіщенний деспот" Карлос III (правив з 1759 по 1788 рр.), дедалі білыпе розчаровувала, обурювала й насторожувала вищі креольські класи. Під час того, що глузливо йменувалося другим підкоренням Америки, Мадрид встановив нові податки, домігся їх ефективнішого збирання, лапровадив комерційні монополії метрополії, обмежив на свою користь міжконтинентальну торгівлю, централізував и/міністративну ієрархію та заохочував посилену імміграцію так званих peninsulares [півостровитян] ${ }^{15}$. Мексика, приміром, на початку вісімнадцятого сторіччя забезпечувала мо॥архію щорічним прибутком близько 3,000,000 песо. Однак паприкінці сторіччя ця сума виросла майже вп'ятеро, до 1/,000,000, з яких тільки 4,000,000 витрачалось на покриття нидатків місцевої адміністрації ${ }^{16}$. Паралельно з цим, рівень міграції з півострова в 1780-1790 рр. був уп'ятеро вищий. ніж y $1710-1730$ pp. $^{17}$

Безсумнівно й те, що вдосконалення трансатлантичних комунікацій і той факт, що різні Америки поділяли з відиювідними метрополіями спільні мови й культури, сприяли июрівняно легкому й швидкому поширенню нових економіч-

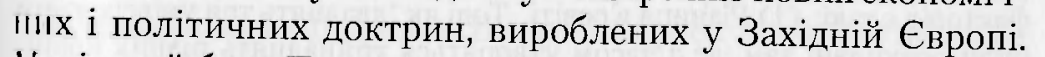
○спішний бунт Тринадцяти Колоній наприкінці 1770-х рp. i вибух французької Революції в кінці 1780-х у свою чергу 'щравили потужний вплив. Немає кращого підтвердження иісі “культурної революції”, ніж глибокий республіканізм

${ }^{15}$ Ця нова агресивність метрополії була породженням частково "росвітницьких доктрин, частково хронічних фінансових проблем i 'liє'тково, після 1779 р., війни з Англією. Lynch. The Spanish-American Revolirions, pp. 4-17.

${ }^{16}$ Ibid., p. 301. Чотири мільйони йшли на субсидії для адміністрування ппими частинами Іспанської Америки, а шість мільйонів - це був чистий "џибуток.

${ }_{17}$ Ibid., p. 17. 


\section{УЯВЛЕНІ СПІЛЬНОТИ}

нових самостійних спільнот ${ }^{18}$. Ніде на американському континенті не робилося жодних серйозних спроб відродити династичний принцип, крім Бразилії; та навіть там це не було б можливим, коли 6 не імміграція у 1808 р. представника португальської династії, який тікав від Наполеона. (Він лишився там протягом 13 років, а повертаючись додому, коронував свого сина, оголосивши його Педро I Бразильським. ${ }^{\text {is }}$ )

I все-таки агресивність Мадрида й дух лібералізму, якими 6 суттєвими вони не були для розуміння першопричин опору в іспанських Америках, самі по собі не пояснюють, чому такі утворення, як Чілі, Венесуела й Мексика, виявилися емоційно вірогідними й політично життєздатними ${ }^{20}$, або чому Сан Мартін звелів називати частину аборигенів неологізмом "перуанці". Зрештою, не пояснюють вони й усі принесені жертви. Адже, хоча й безперечним $є$ те, що вищі креольські класи, як історичні соціальні утворення, в цілому виграли

${ }^{18}$ Конституція Першої Венесуельської Республіки (1811) була в багатьох місцях дослівним запозиченням з Конституції Сполучених Штатів. Masur. Bolizar, p. 131.

${ }_{19}$ Чудовий детальний аналіз структурних засад бразильської винятковості знаходимо в: Jose Murilo de Carvalho. "Political Elites and State Building: The Case of Nineteenth-Century Brazil", Comparative Studies in Society and History, 24:3 (1982), pp. 378-399. Двома з найважливіших факторів є такі: (1) Різниця в освіті. Тоді як “двадцять три університети були розкидані там, де з часом утворяться тринадцять різних країн" Іспанської Америки, "Португалія систематично відмовляла в дозволі на організацію будь-яких вищих учбових закладів у своїх колоніях, не вважаючи такими теологічні семінарії". Вища освіта здобувалася тільки в Коїмбрському Університеті, отож туди, до метрополії, відправлялися діти креольської еліти, переважна більшість яких навчалася на факультеті права. (2) Різні кар'єрні перспективи для креолів. Де Карвальо вказує на "значно більший опір з іспанського боку [sic] допущенню до високих посад іспанців родом з Америки". Також див.: Stuart B. Schwartz. "The Formation of a Colonial Identity in Brazil”, chapter 2 in Nicholas Canny and Anthony Pagden, eds, Colonial Identity in the Atlantic World, 1500-1800, який зазначає мимохідь (с. 38), шо “протягом перших трьох століть колоніальної ери в Бразилії не діяло жодного друкарського верстата”.

${ }^{20}$ Майже те саме можна сказати про позицію Лондона щодо Тринадцяти Колоній та ідеологію Революції 1776 року. 
іiц пезалежності, багато хто з конкретних представників цих и.liciв, котрі жили між 1808 і 1828 рр., зазнали фінансового "раху. (Хоча б ось такий приклад: під час контрнаступу Мідрида у 1814-1816 рр. “понад дві третини землевласı!ıьких родин Венесуели зазнали суттєвих конфіскацій”"21.) liiraто хто з них віддав задля справи власне життя. Ця 1 1товність до самопожертв з боку привілейованих класів дає июживу для роздумів.

Цо ж тоді? Початок відповіді можна знайти у тому |1.1.310чому факті, пцо “кожна з нових південноамериканських юскублік була адміністративною одиницею з шістнадцятого II0 вісімнадцяте сторіччя"“ . В цьому відношенні вони були и)едтечами нових африканських i, частково, азіатських ц.ржав середини XX ст. й різко контрастували з новими ' ґюпейськими державами кінця дев'ятнадцятого й початку ињідцятого століть. Первісні обриси адміністративних одиІщщц в Америці були до певної міри довільними й випадковимII, окреслюючи просторові межі конкретних військових liњвювань. Та з часом вони ставали все тривкішими під шіливом географічних, політичних і економічних факторів. Вже сама безмежність Іспанської Америки, надзвичайна pi:31оманітність їі земель і клімату й, понад усе, неймовірна ускладненість комунікацій у доіндустріальну еру, надавала цим одиницям самодостатнього характеру. (В колоніальну '・оху морська подорож з Буенос-Айреса до Акапулько заимала чотири місяці, а зворотній шлях ще довше; сухопутній перехід з Буенос-Айреса до Сантьяго звичайно тривав два місяці, а до Картахени дев'ять ${ }^{23}$.) Крім того, комерційна имлітика Мадрида сприяла перетворенню адміністративних (1циниць у відокремлені економічні зони. “Американцям юуло заборонено конкурувати з метрополією, і навіть різні 'Іастини континенту не мали права торгувати між собою.

${ }^{21}$ Lynch. The Spanish-American Revolutions, p. 208; порів.: Masur. Bolivar, 1]). $98-99$ and 231.

${ }^{22}$ Masur. Bolivar, p. 678.

${ }^{23}$ Lynch. The Spanish-American Revolutions, pp. 25-26. 


\section{УЯВЛЕНІ СПІЛЬНОТИ}

Американські товари дорогою з одного кінця Америки в інший повинні були переходити через іспанські порти, а іспанське судноплавство мало монополію на торгівлю з колоніями" ${ }^{24}$. Всі ці фактори допомагають з'ясувати, чому "однією з головніших засад американської революції” був принцип "uti possidetis, згідно з яким кожна нація зберігала територіальний status quo 1810 року, ознаменованого початком руху за незалежність" ${ }^{25}$. Вони також, безсумнівно, вплинули на розпад недовговічної Великої Колумбії Болівара та Сполучених Провінцій Ріо де ла Плата на попередні складові частини (відомі нині як Венесуела-Колумбія-Еквадор і Аргентина-У ругвай-Парагвай-Болівія). Однак самі по собі ринкові зони, "природньо"-географічні чи політико-адміністративні, не створюють собі вірних прихильників. Хто готовий віддати життя за РЕВ [Раду Економічної Взаємодопомоги] чи $\mathrm{CEC} \mathrm{[Європейський} \mathrm{Економічний} \mathrm{Союз]?}$

Ццоб зрозуміти, як адміністративні одиниці поступово починають сприйматися батьківщиною, не тільки на американському континенті, але і в інших частинах світу, необхідно розглянути, яким чином адміністративні структури продукують смисли. Антрополог Віктор Тернер яскраво змалював "мандрівку" поміж часами, статусами й місцями як смислоутворюючий досвід ${ }^{2 \varsigma}$. Усі подібні мандри потребують інтерпретації (скажімо, подорож від народження до смерті стала джерелом багатьох релігійних концепцій). Для нашої мети моделлю такої мандрівки $є$ паломництво. Міста Рим, Мекка або Бенарес не просто були для християн, мусульман

\footnotetext{
${ }^{24}$ Masur. Bolivar, p. 19. Природньо, шо пі заходи здійснювалися тільки частково, й завжди вельми поширеною була контрабанда.

${ }^{25}$ Ibid., p. 546.

${ }^{26}$ Iив.: Victor Turner. The Forest of Symbols, Aspects of Ndembu Ritual, особливо частину: "Betwixt and Between: The Liminal Period in Rites de Passage". Пізніші, детальніші розробки знаходяться в його Dramas, Fields, and Metaphors, Symbolic Action in Human Society, chapter 5 ("Pilgrimages as Social Processes") and 6 ("Passages, Margins, and Poverty: Religious Symbols of Communitas").
} 
'и індусів центрами сакральної географії, але їхня центральпість переживалась і "реалізовувалась" (в драматургічному (')гсі) у невпинному потоці пілігримів, які рухалися до них 13 віддалених і не пов'язаних якось інакше між собою місцсвостей. Справді, в певному розумінні зовнішні межі старих релігійних уявлених спільнот визначалися тим, в яке саме піломництво вирушають їх народи ${ }^{27}$. Як зазначалося раніше, нссподіване фізичне зіткнення малайців, персів, індійців, берберів і турків у Мецці було б незбагненним без ідеї про щсвну їхню спільність. Бербер, зустрівшися з малайцем біля Кiаби, мав би, мабуть, поцікавитись: "Чому цей чоловік жбить те саме, що й я, говорить ті самі слова, що й я, хоч ми ı иим навіть не можемо порозмовляти?". На це, як виявляє ıін, існує лиш одна відповідь: “Тому що ми... мусульмани”. : иичайно, завжди існував подвійний аспект хореографії ш'ликих релігійних паломництв: численні юрби неписьменинх носіїв діалектів створювали насичену, фізичну реальпість церемоніального дійства; тоді як невеличкий прошарок жсвічених двомовних адептів, вибраних із кожної народномювної спільноти, виконував об'єднувальні ритуали, витлумачуючи відповідно своїм послідовникам значення їхньої к)лективної акції . В додрукарську епоху реальність уявлеших релігійних спільнот великою мірою зумовлювалась нем.лічнними, безперервними подорожами. Ніщо так не вра: в вахідному християнстві часів його розквіту, як доброиільний потік вірних прочан з усієї Європи до Рима, що ироходив через уславлені "регіональні центри" чернечої пиуки. Ці великі латиномовні заклади зводили тих, кого б

Див.: Bloch. Feudal Society, I, p. 64.

Тут простежуються очевидні аналогії з відповідними ролями, які ицігравали двомовна інтелігенція й переважно неграмотні робітники й юляни у виникненні деяких націоналістичних рухів - до появи радіо. ßилайдене щойно 1895 р., радіо дало можливість обминати друк і ствоpюнати слуховий образ уявленої спільноти там, куди не досягав друкониний аркуш. Його роль у в'єтнамській та індонезійській революціях, як 1. игалом у націоналістичних рухах середини XX ст., все ше недооцінена й мімодосліджена. 
ми иині, напевно, вважали б ірландцями, датчанами, португальцями, німцями тощо, докупи у спільноти, сакральне значення яких щоденно дешифровувалося з непояснимого інакше скупчення їх членів у трапезній.

Хоча релігійні паломництва, мабуть, були найбільш зворушливою й грандіозною мандрівкою уяви, вони мали й мають скромніших і обмеженіших секулярних двійників ${ }^{29}$. Для нас найважливішими являються різноманітні переміщення, спричинені ростом абсолютистських монархій i, згодом, євроцентричних світових імперських держав. У природі абсолютизму було створення уніфікованого апарату влади, безпосередньо контрольованого й лояльного правителю, а не децентралізованій, партикуляристичній феодальній знаті. Уніфікація означала взаємозамінюваність людей і документів. Її пришвидшувало рекрутування - в різних, природньо, масптабах - homines novi, які, власне з цієї причини, не мали жодної самостійної влади, стаючи еманацією волі своїх володарів $^{30}$. Таким чином, функціонери абсолютизму вирушали в мандри, які істотно відрізнялися від подорожей феодальних вельмож ${ }^{31}$. Цю різницю можна зобразити так: в модальній феодальній подорожі спадкоємець Вельможного А. після смерті батька підноситься на один крок, щоб зайняти батькове місце. Це сходження вимагає подорожі в двох напрямках - у центр для формального отримання титулу, а тоді назад до успадкованого маєтку. Для нового функціонера, однак, все це ускладнюється. Він пробиває собі дорогу завдяки здібностям, а не чиїйсь смерті. Перед ним радше вершина, а не центр. Підіймаючись своїм звивистим шляхом,

\footnotetext{
${ }^{29}$ Не треба сприймати “секулярне паломництво" просто як вигадливий троп. Конрад з долею іронії, але досить точно назвав "паломниками" примарних агентів Леопольда II в серці пітьми.

${ }_{30}$ Особливо там, де: (а) релігійно й легально була запроваджена моногамія; (б) нормою було право первородства; (в) нединастичні титули були спадкоємними, а також концептуально й легально відмінними від службових рангів: тобто там, де провінційна аристократія мала значну самостійну владу - в Англії, скажімо, на відміну від Сіаму.

${ }^{31}$ Див.: Bloch. Feudal Society, II, pp. $422 \mathrm{ff}$.
} 


\section{КРЕОЛЬСЬКІ ПЕРШОВІДКРИВАЧІ}

ші постійно долає вигини й закрути, сподіваючись, що біля ‘амї верхівки вони стануть плавнішими й коротшими. لІ)чинаючи з містечка А. у ранзі К., він може повернутись л) столиці в ранзі Л.; відправитись до провінції Б. в ранзі М.; опинитись біля віце-короля В. у ранзі Н.; і завершити 'шоє паломництво в столиці в ранзі О. В цій подорожі немає lil)антованого місця відпочинку; кожна пауза $є$ тимчасовою. I жодному разі функціонер не хоче вертатися додому; адже іiп не має справжнього дому. I ще: на цій закрученій дорозі шгору він зустрічає в ролі завзятих прочан-побратимів своїх кілгег-чиновників, з місць і родин, про які він мало що чув i (ичити які він зовсім не бажає. Але співпережиття колектив॥юї мандрівки породжує усвідомлення пов'язаності (“Чому ми...mут...разом?"), тим паче, коли всі спілкуються єдиною цер)жавною мовою. Тоді, якщо урядовець А. з провінції Б. liрує провінцією В., а урядовець Г. з провінції В. керує провінцією Б. - ситуація, що стає можливою при абсолютизмі - цей досвід взаємозамінюваності починає потребувати шитлумачення: ідеології абсолютизму, яку нові чиновники широбляють нарівні з правителями.

Взаємозамінність документів, якою був підкріплений Ікдський взаємообмін, стала наслідком розвитку стандарти. ваної державної мови. Як продемонструвала послідовна мміна англо-саксонської, латинської, норманської й ранньоiн1лійської мов, що ними користувались у Лондоні з одинадиятого по чотирнадцяте сторіччя, будь-яка писемна мова могла, в принципі, відігравати цю функцію - за умови отримання нею монопольних прав. (Можна, однак, доводити, що l:ı, де монополією заволоділи народні мови, на відміну від Пітини, відбувалася подальша централізація шляхом обмеження переходу службовців одного правителя до апарату iा)го суперника: забезпечуючи, так би мовити, неможливість гого, щоб мадридські функціонери-паломники могли мінятися місцями з паризькими.)

В принципі, позаєвропейська експансія великих королівств ранньої модерної Європи просто мала б застосувати и'нуючу модель для створення значних трансконтиненталь- 


\section{УЯВЛЕНІ СПІЛЬНОТИ}

них бюрократій. Проте, цього, фактично, не сталося. Визначальна раціональність абсолютистського апарату - понад усе його тенденція до відбору й просування по службі на основі радше таланту, а не походження - спрапьовувала лише деколи поза східними берегами Атлантики .

Очевидною є схема, що діяла на Американському континенті. Скажімо, до 1813 року зі 170 королівських намісників в Іспанській Америці було тільки 4 креола. Цифри ці вражатимуть ще більше, якщо врахувати, що 1800 року менш аніж 5\% з 3,200,000 “білих" креолів у Західній Імперії (серед майже 13,700,000 тубільців) були корінними іспанцями. У Мексиці напередодні революції був тільки один креольський єпископ, хоча креоли в королівському намісництві переважали чисельно peninsulares у пропорції 70 до $1^{\text {.”. }}$. Можна й не згадувати про те, що нечуваним було б отримання креолом будь-якої поважної офіційної посади в Іспанії: . До того ж, паломництва креольських функціонерів були заборонені не тільки по вертикалі. Якщо урядовці з півострова могли вирушити в дорогу з Сарагоси до Картахени, Мадрида, Ліми й

32 Звичайно, не варто перебільшувати цю раціональність. Приклад Сполученого Королівства, в якому католикам до 1829 року не дозволялося займати службові посади, неє унікальний. Хіба можна сумніватися, шоця довга заборона відіграла важливу роль у виникненні ірландського націоналізму?

${ }^{33}$ Lynch. The Spanish-American Revolutions, pp. 18-19, 298. 3 майже 15,000 peninsulares половину складали солдати.

${ }_{34}$ В першій декаді дев'ятнадцятого сторічя в Іспанії можна було в будь-який час нарахувати близько 400 південноамериканських мешканців. До їх числа входили “аргентинець" Сан Мартін, який опинився в Іспанії маленьким хлопчиком і провів там наступних 27 років, вступивши до Королівської Академії для шляхетного юнацтва й відіграючи значну роль у військовій боротьбі з Наполеоном перед поверненням на батьківццину після вістки про оголошення незалежності; і Болівар, який деякий час квартирував у Мадриді разом із Мануелем Мелло, "американським" коханцем королеви Марії Луїзи. Мазур описав його приналежність (близько 1805 року) до "групи молодих південноамериканців", котрі, подібно до нього самого, "були багаті, бездіяльні й знаходились у немилості королівського двору. Гнів і почуття меншовартості по відношенню до метрополії народжувало в креолів революційні імпульси". Boltvar, pp. 4147 and 469-470 (San Martin). 
1нґзад до Мадрида, "мексиканський” або "чілійський" креол, ик правило, служив лише на теренах колоніальної Мексики ॥ю Чілі: його горизонтальний рух був не менш обмеженим, ніж вертикальне просування. Таким чином, вершиною його .иивистого шляху догори, найвищим адміністративним центюм, відведеним йому, ставала столиця імперської адміністрапивної одиниці, в якій він опинився . Проте впродовж цього обмеженого паломництва він зустрічав компаньйонів-подоюжжніх, які починали усвідомлювати, що їхнє побратимство базується не лише на специфічному просторі саме цього па.юмництва, але й на спільній невідворотності трансатлантичиюго місця народження. Навіть, якби він народився всього 'юрез тиждень після батькової міграції, сам факт народжения на Американському континенті вже свідчив би про його підлеглість - хоча й щодо мови, релігії, походження або манер його неможливо було б відрізнити від корінного іспанця. :3 цим нічого не можна було вдіяти: він залишався незмінио креолом. Але ж якою ірраціональною мала здаватися йому пака неповноцінність! Однак, ця ірраціональність приховунала в собі наступний логічний висновок: народившись у Америці, він не міг бути справжнім іспанцем; ergo, народивинись в Іспанії, peninsular не міг бути справжнім американцем ${ }^{3 .}$.

${ }^{35}$ Військові паломництва з часом стали важливими не менш від цишільних. "Іспанія не мала ні грошей, ні людських ресурсів для утримання ж'ликих гарнізонів регулярного війська в Америці, тому вона головним џнном покладалась на колоніальну міліцію, шо розширювалась і ре(1)ганізовувалась, починаючи з середини вісімнадцятого століття" (Ibid., ю. 10). Ці загони міліції були цілком локальними, невзаємозамінними часТнгами континентального апарату безпеки. Їх роль постійно зростала від 1760-х pр. і далі, коли почастішали британські вторгнення. Батько Болівара був визначним міліційним командиром, що захищав від нападників иорти Венесуели. Болівар і сам ще підлітком служив у старому батьків'"љкому загоні. (Masur. Bolivar; pp. 30 and 38). В цьому відношенні це було типовим для багатьох націоналістичних лідерів першої генерації з Арген'юни, Венесуели й Чілі. Див.: Robert L. Gilmore. Caudillsm and Militarism in Venezuela, 1810-1910, chapter 6 ["The Militia"] and 7 ["The Military"].

36 Зауважмо трансформацію, яка відбулася з американцями після исзалежності: іммігранти першого покоління перетворилися з "найвищих" 
Чому ж ця неповноцінність виглядала раціональною 3 погляду метрополії? Завдяки, безсумнівно, поєднанню освяченого часом мак'явеллізму з поширюваними концепціями біологічного й екологічного забруднення, шо супроводжували, починаючи від шістнадцятого століття, планетарну експансію європейців і європейської влади. 3 точки зору суверенів, американські креоли, число яких і місцева закоріненість зростали з кожним поколінням, представляли собою унікальну в історії політичну проблему. Вперше - в новій добі - метрополії мали справу з величезною кількістю “співвітчизників-європейців" (понад три мільйони до 1800 року в Іспанській Америці) далеко поза межами Європи. Якщо тубільців можна було підкорити зброєю й хворобами та контролювати за допомогою християнських таїнств і цілковито чужої їм культури (а також прогресивної, як на ті часи, політичної організації), то це не відносилось до креолів, яких, фактично, зброя, хвороби, християнство й європейська культура стосувались у тій самій мірі, що й мешканців метрополії. Інакше кажучи, вони, в принципі, мали у своєму розпорядженні всі політичні, культурні й військові чинники для успішного обстоювання своїх прав. Вони являли собою водночас колоніальну спільноту й вищу верству. Були економічно підлеглими й визискуваними, але також невід'ємними для стабільності імперії. В цьому світлі можна уздріти певні паралелі між положенням креольських магнатів і феодальних баронів, які мали вирішальне значення для влади сюзеренів, але несли їм і загрозу. Таким чином peninsulares у ролі королівських намісників і єпископів виконували ті самі функції, що й homines novi протоабсолю-

у “найнижчих", тобто найбільш забруднених фатальністю місця народження. Подібні інверсії трапляються як реакція на расизм. “Чорна кров" - негритянська домішка - вважалась при імперіалізмі забруднюючим фактором для будь-якого "білого". Нині, принаймні у Сполучених Штатах, "мулат" стає музейним експонатом. Найменший слід “чорної крові” $є$ ознакою представника прекрасної чорної раси. Порівняймо з оптимістичною програмою мішаних шлюбів Ферміна, якого не турбував колір майбутніх нашадків. 
гшстських бюрократій ${ }^{37}$. Навіть якщо намісник був грандом ॥ себе на батьківщині, в Андалузії, то тут, на відстані в 5,000 миль, поруч із креолами, він був, фактично, homo novus, цілковито залежний від свого володаря з метрополії. Підтримування нестійкої рівноваги між службовцем з півострова й креольським магнатом було, таким чином, виявом старої політики divide et impera в новій обстановці.

Крім цього, зростання креольських спільнот, головним 'шном на американському континенті, але теж і в частинах ^:зї й Африки, неминуче вело до того, що євразійці, євроiфриканці, як і євроамериканці, ставали вже не випадковою цивиною, а виразними соціальними групами. 3 іх появою рззквітнув спосіб мислення, що став предтечою сучасного расизму. Португалія, одна з найперших європейських за1:рбниць планетарного масштабу, чудово ілюструє таку г)чку зору. В останній декаді п'ятнадцятого сторіччя Дон Мануель I ще міг “розв'язувати" “єврейське питання” ІІляххм масового примусового навертання - мабуть, останпііі європейський правитель, якому подібне вирішення здапалося задовільним і “природнім"з8. Однак, менш ніж за r'тріччя ми вже бачимо, як Александр Валіньяно, видатний жорганізатор єзуїтської місії в Азії між 1574 і 1606 рр., палко иперечує проти доступу індійців $\mathrm{i} є в$ воіндійців до лав духовенства такими ось аргументами ${ }^{3.9}$ :

Bci ці темні раси є тупими й розпусними... Шодо mestiços i castiços, ї треба приймати в дуже малих кількостях, або не приймати взагалі; особливо це стосується mestiços, адже чим більше в них місцевої крові, тим сильніше вони нагадують індійців і тим меншою користуються повагою серед португальців.

" Враховуючи велику запікавленість Мадрида в тому, щоб управління «)лоніями знаходилося в надійних руках, "самоочевидним було те, шо п:เйвищі посади займалися винятково корінними іспанцями”. Masur. Bolivar, p. 10.

${ }_{38}^{38}$ Charles R. Boxer. The Portuguese Seaborne Empire, 1415-1825, p. 266.

${ }^{39}$ Ibid., p. 252. 


\section{УЯВЛЕНІ СПІЛЬНОТИ}

(Проте Валіньяно активно підтримував виконання функцій священиків японцями, корейцями, китайцями та "індокитайцями" - може, тому, що в цих регіонах метиси ще не з'явилися?) Подібним чином, португальські францисканці в Гоа чинили відчайдушний опір залученню креолів до свого ордену, стверджуючи, що "навіть народившись від чистокровних білих батьків, [вони] в дитинстві годувалися грудьми індійських айя, тому їх кров занечищена на все життя" Як показує Боксер, "расові” бар'єри й заборони помітно зросли, порівняно з минулою практикою, у сімнадцятому й вісімнадцятому сторіччях. До цієї згубної тенденції додалось відновлення великомасштабного рабства (вперше в Європі 3 античних часів), започатковане після 1510 року Португалією. Вже в 1550-х роках 10\% населення Лісабона складалося з рабів; до 1800 р. серед майже 2,500,000 мешканців португальської Бразилії було близько мільйона рабів ${ }^{41}$.

Просвітництво також побічно вплинуло на кристалізацію фатальних розбіжностей між жителями метрополії й креолами. За час свого двадцятидвохрічного перебування при владі (1755-1777) просвічений автократ Помбаль не тільки повиганяв з португальських володінь єзуїтів, але й проголосив карним злочином обзивання "кольорових" суб'єктів образливими словами, такими як "негритос" чи "mestiçо" [sic]. Проте на виправдання свого указу він цитував давньоримські концепції імперського громадянства, а не доктрини філософів ${ }^{* 2}$. Типовішим являвся вклад праць Руссо й Гердера, які доводили, що клімат і “екологія” справляють вирішальний вплив на культуру й характер ${ }^{43}$. 3 усього цього надто легко було зробити зручний і вульгарний умовивід про те, що креоли, родом із дикої півкулі, вже за своєю природою

\footnotetext{
${ }^{40}$ Ibid., p. 253.

Rona Fields. The Portuguese Revolution and the Armed Forces Movement,

Boxer. The Portuguese Seaborne Empire, pp. 257-258.

Kemilainen. Nationalism, pp. 72-73.
} p. 15. 
шідрізнялися й були нижчими від мешканців метрополії - а "юже непридатними для високих посад ${ }^{44}$.

Досі наша увага була зосереджена на чиновницьких колах ıмериканського континенту - стратегічно важливих, але д)сить вузьких світах. До речі, ці світи, з їх конфліктами між peninsulares і креолами, передували становленню амемиканської національної свідомості наприкінці вісімнадцяIюro сторіччя. Обмежені паломництва королівських намісшиків не відігравали вирішального значення, поки їхній гериторіальний простір не уявлявся нацією, інакше кажучи, поки сюди не прийшло капіталістичне друкарство.

Друк, сам по собі, рано поширився в Новій Іспанії, але протягом двох сторіч він перебував під жорстоким контролсм корони й церкви. До самого кінця сімнадцятого століття л)укарські преси існували лише в Мехіко й Лімі, а їхня иродукція була майже винятково церковною. В протестант‘'кій Північній Америці друкарства в цьому столітті пракІпчно не існувало. Однак, упродовж вісімнадцятого віку відбулася справжня революція. Між 1691 і 1820 рр. було опубшіковано не менше 2,120 "газет", з яких 461 протривала понад «сять років .

3 креольським націоналізмом північноамериканського континенту нерозривно пов'язана постать Бенджаміна Франкліна. Проте менш очевидним $€$ його комерційне значення. З пову багато на що проливають світло Февр і Мартен. Вони иам нагадують, що "протягом вісімнадцятого сторіччя друкарство в [Північній] Америці не почало істотно розвињатися, аж поки друкарі не відкрили нове джерело прибут-

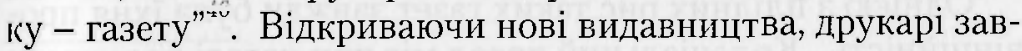

${ }^{44} Я$ тут наголосив на расових відмінностях, по розмежовували peninsulares і креолів, бо головним чином ми розглядаємо зростання креольського націоналізму. Цим ми аж ніяк не хотіли б применшувати : ачення росту креольського расизму по відношенню до метисів, негрів та індіанців; ані готовності з боку незагроженої метрополії захистити (до деякої міри) цих бідолах.

${ }^{45}$ Febvre and Martin. The Coming of the Book, pp. 208-211.

${ }^{46}$ Ibid., p. 211. 
жди включали до своїх виробничих планів публікування газет, головними, як не єдиними співробітниками яких вони самі й були. Таким чином, друкар-журналіст являвся напочатках суто північноамериканським феноменом. А позаяк основною проблемою, що вставала перед друкарем-журналістом, було здобуття доступу до читачів, він налагодив зв'язок із поштмейстером, настільки тісний, що часто один заміняв другого. Відповідно, друкарське бюро стало чільним фактором північноамериканських комунікацій та інтелектуального життя спільноти. В Іспанській Америці, хоч повільніше й нерівномірніше, але подібні процеси привели до появи в другій половині вісімнадцятого сторіччя перших місцевих видавництв .

Якими були особливості перших північно- або південноамериканських газет? Спочатку вони, по суті, були ринковими додатками. Початково газетки складалися - крім новин із метрополії - з комерційних повідомлень (коли прибувають і відходять кораблі, якими є поточні ціни на різні товари в різних портах), а також із відомостей про колоніальні політичні призначення, шлюби багатіїв і таке інше. Іншими словами, появу на одній сторінці иъого шлюбу й того корабля, цієі ціни й того єпископа визначала структура колоніальної адміністрації й самої ринкової системи. Таким ось чином, газета з Каракасу цілком природньо й навіть аполітично створювала уявлену спільноту зі специфічної групи колегчитачів, яких стосувалися ці кораблі, наречені, єпископи й ціни. Звісно, що з часом сюди мали б увійти й політичні фактори.

Однією з плідних рис таких газет завжди була їхня провінційність. Колоніальний креол міг при нагоді прочитати мадридську газету (яка, однак, не повідомила б нічого про близький йому світ), але багато чиновників з півострова, що замешкали на тій самій вулиці, радо не читали б каракаську пресу. Асиметрія, відтворювана до безконечності в інших колоніальних ситуаціях. Другою такою рисою була множин-

\footnotetext{
${ }^{47}$ Franco. An Introduction, p. 28.
} 
иість. Іспаноамерпканські часописи, які з'явилися під кінець иiс імнадцятого сторіччя, публікували свої матеріали, завжди пім'ятаючи про провінціалів з паралельних їм світів. Читачі riıет з Мехіко, Буенос-Айреса й Боготи, навіть не читаючи 'іссописів один одного, знали однак про їх існування. Звідси i добре відома подвійність раннього іспаноамериканського пиціоналізму, його мінлива схильність то до грандіозної ш'сохопності, то до партикуляристичного локалізму. Той |) акт, що ранні мексиканські націоналісти називали себс uosotros los Americanos, а свою країну nuestra America, інтериюстувався як вияв марнославства місцевих креолів, котрі уявляли себе центром Нового Світу, бо Мексика була найциннішою іспаноамериканською територією ${ }^{48}$. Але, фактичI10, мешканці всієї Іспанської Америки мислили себе "аме|икканцями", позаяк цей термін дуже точно визначав сукупну | |иітальність народження поза межами Іспанії ${ }^{\star N}$.

Водночас, ми вже знаємо, що сама концепція газети пемщцбачає рефракцію відібраних “світових подій" у специфічший уявний світ локальних читачів; а також те, якою важıІвою для цієї уявленої спільнюти являється ідея сталої, стабільної одночасності в часі. Неосяжні простори Іспано-Американської Імперії та ізольованість її складових частин заваІ.іли уявляти цю одночасність ${ }^{50}$. Мексиканські креоли могIII довідатись про події в Буенос-Айресі місяцями пізніше, ..ле з мексиканських газет, а не з часописів Ріо де ла Плата; i хич події ці здавалися "подібними", проте вони не ставали "Іастиною" мексиканських сенсацій.

${ }^{48}$ Lynch. The Spanish-American Revolutions, p. 33.

"Пеон прийшов поскаржитись на те, шо його побив іспанський на1:лядач ферми. Сан Мартін обурився, але це обурення мало скорше націо॥.ıлістичний, ніж соціалістичний характер. "Що 6 ви собі подумали? Мıнуло три роки після революції, а цей maturrango [вульг., іспанець з пізострова] насмілюеться підняти руку на американця!" Ibid., p. 87.

Магічним втіленням відірваності й ізольованості іспаноамерикан\ икого населення постає образ легендарного Макондо в романі Маркеса "С'то років самотності". 


\section{УЯВЛЕІІ СІІЛЬНОТИ}

В цьому сенсі, “неспроможність” іспаноамериканського досвіду створити сталий націоналізм, шо поширювався б на всю Іспанську Америку, віддзеркалює як загальний рівень розвитку капіталізму й технологій наприкінці вісімнадцятого століття, так і “локальну” відсталість іспанського капіталізму й технологій порівняно з адміністративним обсягом імперії. (Історично-світова доба, в якій з'являється кожен тип націоналізму, мабуть, має великий вплив на його можливості. Чи ж не пов'язаний нерозривно індійський націоналізм з колоніальною адміністративно-ринковою уніфікацією, здійсненою після Повстання однісю з наймогутніших і найрозвиненіших імперських потуг?)

Протестантські англомовні креоли розташувалися в північній частині континенту значно сприятливіше для реалізації ідеї “Америки” і, врешті-решт, успішно привласнили собі назву “американців". Початкові Тринадцять Колоній займали меншу плошу, ніж Венесуела, або лишень третину Аргентини ${ }^{51}$. Зібрані географічно докупи, іхні торгові центри в Бостоні, Нью-Йорку й Філадельфії були доступні один одному, а населення було відносно міцно пов'язане завдяки поширенню друку й комерції. “Сполучені Штати” поступово могли чисельно зростати протягом наступних 183 років, коли старі й нові їх мешканці рухались на захід зі старого осердя на східному узбережжі. Проте навіть у СІША були періоди відносних “невдач" або скорочень - нездатність поглинути англомовну Канаду, десятиріччя незалежної суверенності Техасу (1835-1846). Якби у вісімнадцятому сторіччі в Каліфорнії існувала чимала англомовна громада, чи не могла там з'явитися незалежна держава, протиставивши себе Тринадцяти Колоніям, немов Аргентина Перу? Навіть у США емоціональні узи націоналізму, в поєднанні зі стрімким розширенням західних кордонів і суперечностями, шо виникали між економічними системами Півночі й Півдня, виявились

\footnotetext{
5. Загальна площа Тринадцяти Колоній становила 322,497 квадратних миль. Площа Венесуели була 352,143; Аргентини - 1,072,067; а Іспанської Південної Америки - 3,417,625 квадратних миль.
} 


\section{КРЕОЛЬСЬКІ ПЕРШОВІДКРИВАЧІ}

„цостатньо слабкими для того, щоб протистояти розв'язанню громадянської війни майже через століття після Декларації Незалежності; і ця війна нині нам гостро нагадує ті війни, що відірвали Венесуелу й Еквадор від Великої Колумбії, а У ругвай i.3 Парагваєм від Сполучених Провінцій Ріо де ла Плата ${ }^{52}$.

Підводячи попередні висновки, варто ще раз наголосити на досить вузькому й специфічному спрямуванні наших иргументів. Вони служать не стільки для з'ясування соціо'кономічних підвалин антиметропольного опору в Західній півкулі, скажімо, між 1760 і 1830 рр., скільки для того, щоб иояснити, чому цей опір замислювався у множинних, "націопальних" формах - а не в якихось інших. Економічні інтере' 'I, що були поставлені на карту, є добре відомі й мають, очеипдно, фундаментальне значення. Потужний вплив, безсумнівно, справили на це лібералізм і просвітництво, забезпе'швши, перш за все, арсенал ідеологічної критики, спрямова॥ої на імперські й старі режими [anciens regimes]. Я лише п)ипускаю, що ні економічний інтерес, ні лібералізм, ані про' пітництво не могли або не змогли створити самі по собі такиі видабо взірець уявленої спільноти, що був би захищений шіл руйнівної дії цих режимів; інакше кажучи, жоден із них IIс виробив структуру нової свідомості - ледь помітної на псриферії уяви - на відміну від розташованих у центрі об'єктів 1.1хоплення або обурення ${ }^{3}$. У виконанні цього специфічного 1.1вдання вирішальну історичну роль відіграли креольські |)ункціонери-пілігрими й провінційні креольські друкарі.

${ }^{52}$ Парагвай представляє особливий інтерес. Завдяки відносно добро"1'ıшвій диктатурі, встановленій тут єзуїтами на початку сімнадцятого 1 юріччя, відношення до тубільців було крацим, аніж будь-де в Іспанській Амсриці, а гуарані здобула статус друкованої мови. Внаслідок вигнання Апи:архією єзуїтів з Іспанської Америки 1767 року, територія опинилась l'іо де ла Плата, але занадто пізно й не довше ніж на одне покоління. IIII!: Seton-Watson. Nations and States, pp. 200-201.

Показовим є те, що в Декларації Незалежності 1776 року говориться шIшє про "народ", тоді як слово "нація" вперше з'являється тільки в hиметитуції 1789 року. Kemilainen. Nationalism, p. 105. 


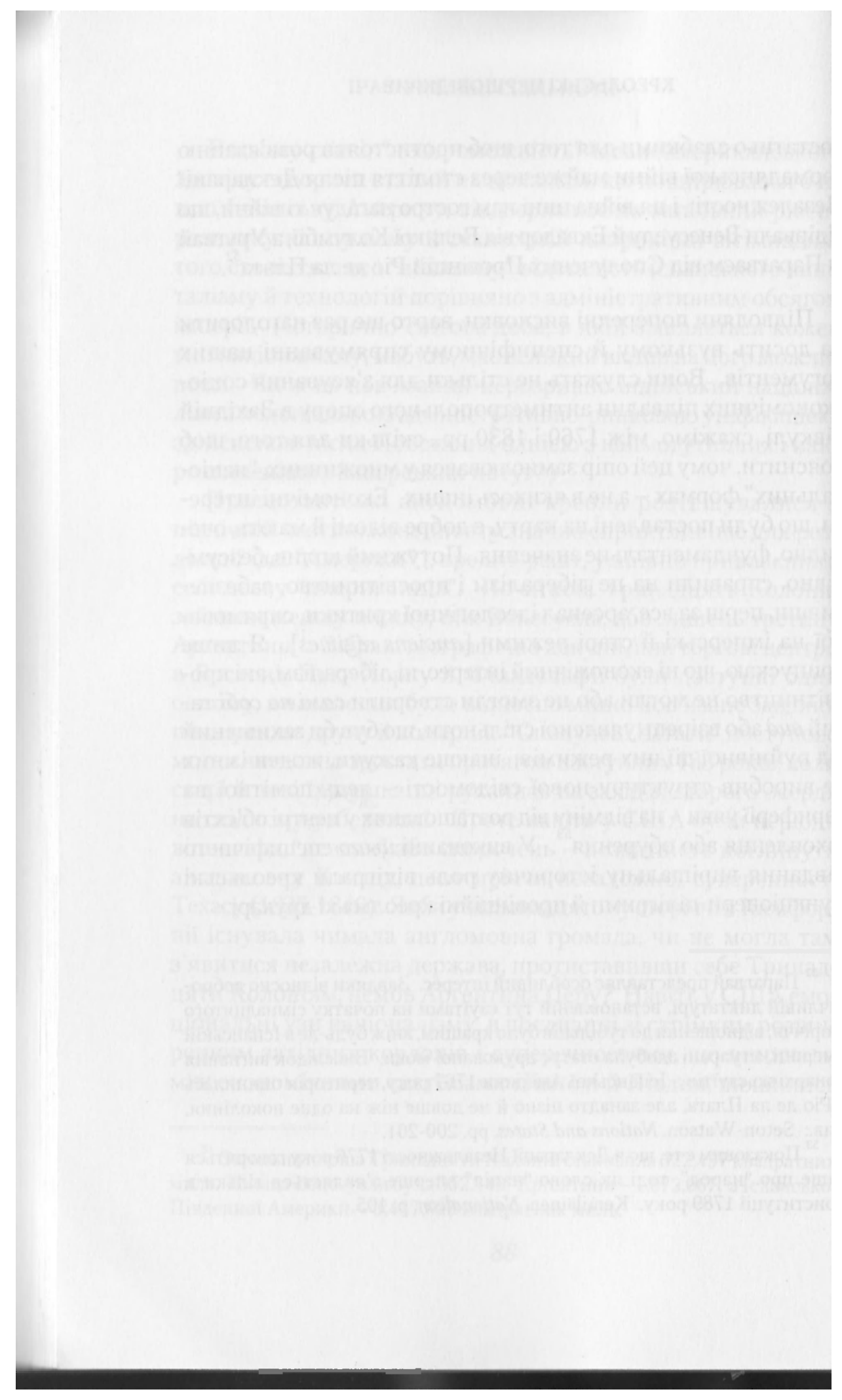




\section{Старі мови, нові моделі}

Завершення доби успішних національно-визвольних рухін на американському континенті досить тісно збігається 3 и1)чатком ери європейського націоналізму. Розглядаючи ха|актер цих нових націоналізмів, котрі в період між 1820 i 1920 pp. змінили обличчя Старого Світу, помічаємо дві раиючі риси, якими вони різняться від предтеч. По-перше, тут майже завжди вирішальне ідеологічне й політичне значення падавалося "національним друкованим мовам", тоді як у жмноюційних Америках іспанська й англійська мови ніколи Іє відігравали істотної ролі. По-друге, можна було вживати шаявні моделі, що дісталися від далеких, а після потрясінь (I)ранцузької Революції й не таких вже далеких попередииків. Таким чином, "нація" відразу стала тим, чого свідомо прагнеться, а не якоюсь розпливчастою візуальною констиукцією. Фактично, як ми переконаємось, "нація" виявилася винаходом, який неможливо було запатентувати. Вона стала цоступною для викрадення руками різних, часом цілком несподіваних піратів. В цьому розділі, відповідно, ми піддімо аналізу друковану мову й піратство.

Легковажно зігнорувавши деякі очевидні позаєвропейські ()акти, славетний Йоганн Готфрід фон Гердер (1744-1803) 
заявив наприкінці вісімнадцятого століття, що: “Denn jedes Volk ist Volk; es hat seine National Bildung wie seine Sprache" [Тому, що кожен народ $є$ народом; він має свою національну структуру, а також свою мову $]^{2}$. Ця зарозуміла вузькоєвропейська концепція нації, як чогось зв'язаного із приватною власністю на мову, мала в Європі дев'ятнадцятого століття попирений вплив, зокрема, на розвиток майбутніх теорій щодо природи націоналізму. В чому джерела цієї ілюзії? Найімовірніше, їх треба шукати в серйозному звуженні європейського світу в часі й просторі, яке розпочалося ще в $\mathrm{XIV} \mathrm{cт.} \mathrm{й} \mathrm{було} \mathrm{викликане} \mathrm{спочатку} \mathrm{історичними} \mathrm{досліджен-}$ нями гуманістів, а згодом, як це не парадоксально, планетарною експансією Європи.

Це дуже добре передав Ауербах"

На самому світанку гуманізму з'явилося відчуття, що події класичної історії й міфології, як і біблійні легенди, були відділені від сучасності не просто відстанню в часі, але й цілковито іншими обставинами життя. Гуманізм зі своєюо програмою відродження античних форм життя й експресії створює історичну перспективу такої глибини, якої не знала жодна попередня епоха: гуманістам, які досліджують античність в усій історичній повноті, розкривається на цьому фоні темна доба Середньовіччя... [Це унеможливлювало] відновлення самодостатнього життя, природнього для античної культури, або історичної наївності XII й XIII сторіч.

Розвиток, так би мовити, “компаративної історії” з часом привів до появи нечуваної доти концепції "модерності", виразно протиставленої “античності", причому зовсім не обов'язково на користь останньої. Ця проблема палко дискутувалася під час "Суперечки про старих і нових авторів", що домінувала у французькому інтелектуальному житті протягом останньої чверті XVII ст." I знову зацитуємо Ауербаха:

\footnotetext{
${ }^{1}$ Kemilainen. Nationalism, p. 42. Виділено нами.

${ }^{2}$ Mimesis, р. 282. Виділено нами.

${ }^{3}$ Битва розпочалась у 1689 р., коли 59-річний Шарль Перро опуб-
} 
"Iри Людовику XIV французи відважилися вважати свою 1./асну культуру взірцевою, рівною культурі античності, й ıни нав'язали цю думку решті Європи"“.

Впродовж XVI ст. “відкриття" Європою грандіозних цивілізацій, доти ледве знаних - Китаю, Японії, Південно( ххідної Азії й Індійського субконтиненту - або й цілком псвідомих - Мексики ацтеків і Перу інків - засвідчило непоц(1)ланну різноманітність людських культур. Більшість із цих цивілізацій розвивалися цілком незалежно від відомої єврошсйської, християнської, античної та й, узагалі, людської істоpiï: їхні генеалогії знаходились за межами Едему й не були д( нього возведеними. (Їх можливо було вмістити лише в (1цाорідному порожньому часі.) Вплив, які справили ці "відкриття", можна оцінити, звернувшись до своєрідної геоІ рифрії вимислених держав тієї доби. “Утопія" Мора, яка виишлла 1516 року, стилізувалась під розповідь моряка, учасшика експедиції Амеріго Веспуччі до Америки 1497-1498 юків, якого автор нібито зустрів у Антверпені. "Нова І Іплантида" (1626) Френсіса Бекона була новою перш за все, мабуть, тому, що розміщувалася в Тихому Океані. Острів гуїпгів Свіфта (1726) супроводжувала псевдокарта його иівденноатлантичного розташування. (Смисл цих локалізаціиі стає ясніший, коли задумаємося над тим, наскільки щ'мислимо було б помістити Республіку Платона на будьикій карті, справжній чи вигаданій.) Усі ці іронічні утопії, палххнені дійсними відкриттями, змальовано не як втрачені қiї, а як суцасні суспільства. Можна твердити, що вони й мілли такими бути, адже задумувались як критика сучасних 'ууспільств, а завдяки відкриттям зникла необхідність відпукувати моделі у зниклій древності ${ }^{3}$. Після утопістів при-

лікував свою поему "Siecle de Louis le Grand", в якій доводив, шо мистецтва i иауки досяглг найвишого розквіту саме в його часи й його країні.

Mimesis, p. 343. Зауважмо, що Ауербах каже "культуру", а не "мову". Нам також треба бути обачними, шоб не приписувати словам "свою шласну" значення "національну".

Подібний контраст спостерігаємо в зображенні двох знаменитих Монголів англійської драми. У “Тамерлані Великому” (1587-1588) Марло 


\section{УЯВЛЕНІ СПІЛЬНОТИ}

йшли світила Просвітництва - Віко, Монтеск'є, Вольтер і Руссо, які посилено використовували "справжню" не-Свропу у цілій зливі критичних праць, спрямованих проти тогочасних європейських соціальних і політичних інституцій. В результаті стало можливим сприймати Європу лише як одну 3 багатьох цивілізацій, причому не обов'язково вибрану чи найкращу ${ }^{6}$.

У свою чергу, відкриття й завоювання вчинили переворот також і в європейських концепціях мови. Віддавна португальські, голландські й іспанські мореходці, місіонери, купці й солдати складали з практичною метою - навігації, навертання у віру, торгівлі й війни - простенькі словнички неєвропейських мов. Проте наукове порівняльне вивчення мов по-справжньому розпочалося тільки наприкінці XVII ст. Побочним наслідком підкорення Англією Бенгалії стало перше дослідження санскриту (1786) Вільяма Джонса, й все глибше усвідомлення того, що індійська цивілізація набагато старша від грецької чи іудейської. Єгипетська експедиція Наполеона принесла розшифровку ієрогліфів (1835) Жаном Шампольйоном, збільшивши число позаєвропейської древності ${ }^{7}$. Дослідження семітських мов поставили під сумнів ідею унікальної древності або божественного походження староєврейської мови. I знову вибудовувались генеалогії, які можна було вмістити тільки в однорідному, порожньому часі. "Мова ставала все менше ланкою між зовнішньою владою й людиною, й все більше внутрішнім простором, який творять і використовують їі носії" 3 цих відкриттів народилася філологія, з їі дослідженнями порівняльної граматики, класифікацією мов на сім’ї й реконструкцією шляхом

змальовує славного правителя, що помер ще 1407 року. Драйден в "Аурангзебi" (1676) зображує сучасного імператора (1658-1707).

${ }^{6}$ Коли європейський імперіалізм активно торував собі дорогу в світі інші цивілізації також опинились перед травматичною реальністю плюралізму, який нишив їхні сакральні генеалогії. Символом цього процесу стало витиснення Серединної Імперії на периферію Далекого Сходу.

${ }_{7}^{7}$ Hobsbawm. The Age of Revolution, p. 337.

${ }^{8}$ Edward Said. Orientalism, p. 136. 
югічних умовиводів забутих "прото-мов". Як слушно заунажує Хобсбоум, це була "перша галузь науки, яка вважала "љолюцію самою своєю серцевиною".

3 того часу старі сакральні мови - латина, грецька й стаюєврейська - були змушені ділити свій онтологічний статус із різношерстною плебейською юрбою розмовних суперп!ць, що лише поглиблювало їх деградацію, започатковану капіталістичним друкарством. Якщо всі мови відтепер мали 'пільний світський статус, усі вони, в принципі, заслуговуніли на те, щоб їх вивчали й ними захоплювались. Тільки хто мав це робити? За логікою, якщо вже жодна з них не налекіла Богу, нові їхні власники: носії цих мов, а отже й читачі.

Як вельми успішно демонструє нам Сетон-Вотсон, XIX ст. " Свропі та на іï̈ периферії стало золотим віком національпомовних лексикографів, граматиків, філологів і літераторін ${ }^{10}$. Енергійна діяльність цих професійних інтелектуалів була ключовою для формування європейських націоналізмік, що цілком відрізнялося від ситуації на американському мюттиненті між 1770 і 1830 роками. Одномовні словники иули величезними компендіумами друкованої скарбниці к)жної мови, що їх можна було переносити (хоч іноді з трудшщами) 3 крамниці до школи, з роботи додому. Двомовні 1. пкими б не були зовнішні політичні реалії, мови, спаровані піл обкладинкою чесько-німецького/німецько-чеського 'ловника, мали спільний статус. Безкорисливі трудяги, які юками укладали ці словники, неминуче зосереджувались, .ю й спеціально підготовлювались у великих бібліотеках ᄃпропи, перш за все університетських. I так само неминуче

'Hobsbawm. The Age of Revolution, p. 337.

“Саме тому, шо історію мови в наш час здебільшого трактують ни.гільки відособлено від традиційних політичної, економічної й соці1 11.юї історії, мені здавалося бажаним їх поєднати, пожертвувавши навіть игшим рівнем компетентності". Nations and States, p. 11. Насправді, одним I 1 пйцінніших аспектів тексту Сетон-Вотсона якраз і $є$ його увага до мเмиої історії - хоча й можна не погоджуватися з тим, як він їі застосовує. 
іхньою клієнтелою ставали студенти й абітурієнти цих університетів. Афоризм Хобсбоума, по "розвитком шкіл та університетів вимірюється розвиток націоналізму, адже саме школи, а особливо університети стали його найсвідомішими поборниками", безумовно, вірний щодо Європи XIX ст., хоча й не завжди щодо інших часів і місць

Таким чином можна порівняти розвиток цієї лексикографічної революції з наростаючим гуркотом охопленого вогнем арсеналу, коли кожен маленький вибух веде до більшого, аж поки остаточний спалах не обертає ніч на день.

На середину XVIII ст. завдяки гідним подиву зусиллям німецьких, французьких і англійських науковців не тільки став доступним у зручному друкованому вигляді практично весь наявний фонд грецької класики, разом із необхідними філологічними й лексикографічними доповненнями, але ще й десятки книжок відтворювали розкішну й по суті своїй глибоко язичницьку стародавню еллінську цивілізацію. В останній чверті сторіччя це "минуле" ставало дедалі доступнішим невеликому числу молодих грекомовних інтелектуалів-християн, більшість із яких навчалася або жила за межами Османської імперії ${ }^{12}$. Екзальтовані фактом поширення філеллінізму в центрах західноєвропейської цивілізації, вони взялися за “деварваризацію” сучасних греків, тобто

${ }^{11}$ The Age of Revolution, p. 166. Академічні заклади не відігравали значної ролі в американських національних рухах. Сам Хобсбоум зазначає, шо студенти Парижа, яких тоді налічувалось 6,000 , практично не брали жодної учасгі у Французькій Революції (с. 167). Він теж цілком доречно нагадує, шо попри швидке попирення освіти в першій половині XIX ст. кількість учнів, за сучасними стандартами, була ше мінімальною: якихось 19,000 лішеїстів у Франції 1842 року; 20,000 учнів середньої школи в імперській Росії 1850 року з населенням у 68,000,000; ймовірно, всього 48,000 студентів університетів на всю Європу 1848 року. Проте в революції, шо сталась того року, ця невеличка, але стратегічно важлива група відігравала вже кардинальну роль (с. 166-167).

Перші грецькі газети з'явились у Відні 1784 року. "Філіке Гетайрія", секретне товариство, великою мірою відповідальне за анти-Османське повстання 1821 року, було засноване у "новому великому російському зерновому порту Одесі" в 1814 p. 


\section{СТАРІ МОВИ, НОВІ МОДЕЛІ}

:а трансформацію їх у істот, гідних Перікла й Сократа ${ }^{13}$. Симптоматичними для цієї зміни в свідомості є слова одного з цих молодих людей, Адамантіоса Кораеса (котрий пізніше (тав ревним лексикографом!), звернені до французької :удиторії в Парижі 1803 року ${ }^{14}$ :

Вперше нація озирає жахливу картину свого невігластва й тріпотить, вимірюючи оком відстань, що відділяє їі від предківської слави. Це болісне відкриттл, одначе, не повергає греків у відчай: “Ми нащадки греків, - кажуть вони собі, ми мусимо або знову стати гідними цього імені, або не носити його взагалі".

Подібним чином наприкінці XVIII ст. з'явилися румун''ıкі граматики, словники й історії, супроводжені кампанією, успішною спочатку на підвладних Габсбургам територіях, а юді й в Османській імперії, за заміну кирилиці латинським :1/фавітом (що різко відокремило румунів від православних (уусідів-слов'ян) ${ }^{2}$. Між 1789 і 1794 pp. Російська Академія, изірцем для якої була Akademie Fraпçaise, випустила шесптомний словник російської мови, а 1802 року офіційну приматику. Все це свідчило про перемогу розмовної мови 川іц церковнослов'янською. Хоча до XVIII ст. включно чеські в Богемії лишалася мовою виключно селян (аристократія ii ॥ові середні класи вживали німецьку), католицький свящєеик Йосеф Добровський (1753-1829) випустив у 1792 р. r"ю "Geschichte der böhmischen Sprache und ätern Literatur", i'ршу систематизовану історію чеської мови й літератури. Іротягом 1835-1839 рр. з'явився основоположний п'ятитомшии чесько-німецький словник Иосефа Юнгманна ${ }^{16}$.

${ }^{13}$ Див. вступ до: Elie Kedourie. Nationalism in Asia and Africa, p. 40.

Ibid., pp. 43-44. Виділено нами. Повний текст промови Кораеса “ 'учасний стан цивілізації в Греції” наводиться на сторінках 157-182. Він містить на диво злободенний аналіз соніологічних засад грецького и1ціоналізму.

1. Не претендуючи на будь-які компетентні знання щодо Центральної й 1 хідної Свропи, в наступному аналізі я покладався в основному на досліІжюиня Сетон-Вотсона. Відносно румунів див.: Nations and States, p. 177.

${ }^{16}$ Ibid., p. 150-153. 


\section{УЯВЛЕНІ СПІЛЬНОТИ}

Щодо народження угорського націоналізму, Ігнотус пише, що це подія “настільки недавня, що можна назвати їі точну дату: 1772, рік публікації кількох нуднуватих творів угорського автора Дьордя Бессені, який тоді проживав у Відні й служив у ескорті Марії Терези... Ця magna opera Бессені мала довести, що угорська мова придатна для найвищих літературних жанрів" ${ }^{\text {17 }}$. Наступним імпульсом стали численні публікації Ференца Козінці (1759-1831), “батька угорської літератури”, а також перенесення 1784 р. до Будапешта 3 маленького провінційного містечка Трнави майбутнього Будапештського університету. Першим політичним виявом стала в 1780 -х роках ворожа реакція латиномовної угорської знаті на рішення імператора Йосифа II замінити латину німецькою як головною мовою імперської адміністрації".

Протягом 1800-1850 рр. в результаті новаторської праці місцевих вчених на півночі Балкан сформувалися три окремі літературні мови: словенська, сербсько-хорватська й болгарська. Якщо в 1830-х роках “болгари”, за загальним визнанням, належали до тієї самої нації, що й серби з хорватами, й брали участь в Іллірійському русі, то вже в 1878 р. утвориться самостійна болгарська національна держава. У XVIII ст. українську (малоросійську) мову зневажливо толерували як мову гречкосіїв. Але 1798 року Іван Котляревський написав свою "Енёдy", надзвичайно популярну сатиричну поему з українського побуту. В 1804 р. був заснований Харківський університет, який стрімко став центром українського літературного буму. В 1819 р. з'явилася перша українська грама-

\footnotetext{
${ }^{17}$ Paul Ignotus. Hungary, p. 44. "Він таки це довів, хоча його полемічний азарт був переконливіший, ніж естетична вартість наведених ним зразків". Мабуть, варто зазначити, що цей уривок узято з підрозділу під назвого "Винахід угорської нації", який розпочинається з такої вагомої фрази: “Нація народжується, коли декілька осіб виріпують, що так має бути”.

${ }^{18}$ Seton-Watson. Nations and States, pp. 158-161. Реакція була настільки відчайдушною, шо переконала його наступника Леопольда II (правив з 1790 по 1792) в необхідності відновити латину в їі правах. Див. також нижче VII розділ. Показовим $€$ те, що в цьому питанні Козінці підтримав політично Йосифа II. (Ignоtus. Hungary, p. 48).
} 
гика - всього через 17 років після офіційної російської. А в 1830-х роках вийшли твори Тараса Шевченка, про кого Сеююн-Вотсон зазначав, що “формуванням визнаної української пітературної мови завдячуємо йому більше, ніж будь-кому іпшому. Вживання цієї мови стало вирішальною стадією у " юрмуванні української національної свідомості" ${ }^{19}$. Невдовзі після цього, 1846 року, в Києві була заснована - істориком! перша українська націоналістична організація.

У XVIII ст. державною мовою нинішньої Фінляндії була шиведська. Коли її територія опинилася 1809 року під владою иіря, офіційною мовою стала російська. Але "пробудження" иıтересу до фінської мови й історії, виражене спочатку в «кстах, написаних латинською й шведською наприкінці XVIII ст., у 1820-ті рр. все частіше виявлялось за допомогою ніродної мови ${ }^{2 \varsigma}$. Лідерами фінського націоналістичного пуху, що набирав сил, були "особи, здебільшого пов'язані гвоїм фахом із мовою: письменники, вчителі, пастори й мристи. Вивчення фольклору та відкриття наново й збирания в єдине ціле народного епосу відбувалося одночасно з пубпікацісю граматик і словників, ведучи до появи періодичних шидань, які сприяли нормуванню фінської літературної [ пбто друкованої] мови, іменем якої можна було висувати ріпучіші політичні вимоги" ${ }^{21}$. У випадку з Норвегією, яка (о)вгий час мала спільну з датчанами письмову мову, хоча і 3 цілковито інакшою вимовою, націоналізм виник тоді, коли I кар Аасен випустив нову норвезьку граматику (1848) і словник ( 1850 ). Ці тексти стали відповіддю на попит власної норвезької џрукованої мови, а разом з тим і стимулювали його.

За межами Європи ми бачимо афріканерський націоналі.зм, започаткований наприкінці XIX ст. бурськими пастоן:ми й літераторами, котрі в $1870-x$ роках успішно перетво-

\footnotetext{
${ }^{19}$ Nations and States, p. 187. Зрозуміло, шо царизм швидко розправлявся - тікими людьми. Шевченка покарали Сибіром [sic]. Габсбурги, одначе, њякою мірою заохочували українських націоналістів у Галичині июінралізуючи цим дії поляків.

Kemilainen. Nationalism, pp. 208-215.

Seton-Watson, Nations and States, p. 72. 


\section{УЯВЛЕНІ СПІЛЬНОТИ}

рили місцеву голландську говірку в літературну мову й дали ій вже цілком неєвроиейську назву. Мароніти й копти, велику частину яких складали випускники бейрутського Американського коледжу (заснованого 1866 року) та єзуїтського коледжу св. Йосифа (заснованого 1875 року), зіграли вирішальну роль у відродженні класичної арабської мови й поширенню арабського націоналізму ${ }^{22}$. А зерна турецького націоналізму можна легко віднайти в появі жвавої народномовної преси в Стамбулі $1870-x$ років ${ }^{23}$.

Не треба забувати, що цієї ж доби відбулася вернакуляризація ще одного виду друкованого аркуша: партитури. Слідом за Добровським прийшли Сметана, Дворжак і Яначек; після Аасена - Гріг; слідом за Козінці - Бела Барток; і так далі до наступного сторіччя.

Зрозуміло, усі ці лексикографи, філологи, граматисти, фольклористи, публіцисти й композитори діяли далеко не у вакуумі. Зрештою, вони виробляли продукцію для ринку й цим невидимим базаром були пов'язані зі споживацькою публікою. Ким були ці споживачі? Загально беручи, родини освічених, читацьких класів - не просто “працюючий батько", але й оточена слугами дружина та діти шкільного віку. Якщо пригадати, шо не далі, як у 1840 р. навіть у Британії й Франції, найрозвиненіших державах $Є$ вропи, майже половина населення була ще неграмотною (а у відсталій Росії майже 98 відсотків), то “читацькі верстви” складалися 3 людей, наділених певною владою. Точніше, вони становили, на додаток до старих правлячих класів аристократії й помісного дворянства, придворних і духівництва, зростаючі середні верстви дрібних службовців незнатного походження, професіоналів, торгових і промислових буржуа.

${ }^{22}$ Ibid., pp. 232 and 261.

${ }^{23}$ Kohn. The Age of Nationalism, pp. 105-107. Це означало відмову віл "османської", династичної бюрократичної мови, шо поєднувала елементи турецької, перської й арабської мов. Характерно, шо Ібрагім Сінасі заснував першу таку газету, шойно повернувшись після п'яти років навчання у Франції. Невдовзі слідом за ним рушили й інші. В 1876 р. у Константинополі вже було сім шоденних турецькомовних газет. 


\section{СТАРІ МОВИ, НОВІ МОДЕЛІ}

Європа середини XIX ст. стала свідком стрімкого зростання державних видатків і розмірів державної бюрократії (цивільної й військової), попри брак будь-яких значних локальних війн. "Між 1830 і 1850 рр. державні видатки на душу піселення зросли на $25 \%$ у Іспанії, на $40 \%$ у Франції, $44 \%$ в '’сії, 50\% в Бельгії, 70\% в Австрії, 75\% у США й понад 90\% " Нідерландах" . Зростання бюрократії, яке також означало iї спеціалізацію, широко відкривало двері для офіційного просування по службі значно більшій кількості людей строkilтішого, ніж доти, соціального походження. Взяти хоча б цряхлий, перенасичений синекурами, керований аристократію австроугорський державний апарат: процент вихідців 11 середніх класів у вищих ешелонах його цивільної частини широстав із 0 у 1804 р. до 27 у 1829,35 у 1859,55 у 1878 . Така “іма тенденція проявилась і в армії, хоча в характерно споші./ьненому, запізненому темпі: серед офіцерського корпусу 'кладова представників середніх верств зросла з 10 до 75 \% між 1859 i 1918 pp. $^{25}$

Якщо розширення бюрократичного середнього класу піцбувалося відносно рівномірно, як у передових, так і у підсталих європейських країнах, то ріст торгової й промисювої буржуазії проходив, навпаки, дуже нерівномірно ' трімко й потужно в одних місцях, мляво й уповільнено в шипих. Але в будь-якому випадку для зрозуміння явища Іщ,юго "росту" необхідно усвідомлювати його відношення до 1.нпіталістичного друкарства на народних мовах.

Добуржуазні правлячі класи досягали узгодженості пев๗юю мірою поза сферою мови, принаймні, поза сферою друм)заної мови. Якщо правитель Сіаму брав собі за молодшу : ружину малайську аристократку, або якщо англійський король одружувався з іспанською принцесою - чи вони будьили серйозно розмовляли між собою? Солідарність вини-

${ }^{21}$ Hobsbawm. The Age of Revolution, p. 229.

Peter J. Katzenstein. Disjoined Partners, Austria and Germany since 1815, I1). $74,112$. 
кала в результаті кровної спорідненості, ієрархічної залежності й особистої лояльності. "Французька" шляхта могла ставати на бік "англійських" королів у боротьбі з "французькими” монархами не завдяки спільній мові або культурі, а завдяки, якщо не враховувати мак'явеллівські розрахунки, родинним і дружнім зв'язкам. Відносно невелика кількість традиційної аристократії, непорушні її політичні засади й особистісність політичних відносин, залежних від статевих стосунків і спадщин, означали, що їхня класова узгодженість була настільки ж реальною, наскільки й уявленою. Неосвічена знать залишалася знаттю. А буржуазія? Це був клас, який, образно кажучи, став класом лише завдяки великій кількості копій. Власник фабрики в Лілі знав про власника фабрики в Ліоні лише завдяки відлунню. Вони не мали великої потреби знати про існування один одного; як правило, вони не одружувалися з доньками один одного й не успадковували обопільного майна. Проте вони змогли в цілому усвідомити існування тисяч і тисяч собі подібних завдяки друкованій мові. Адже майже неможливо уявити собі неграмотну буржуазію. Таким чином, з історичної перспективи буржуазія стала першим класом, що досяг солідарності на здебільшого уявлених засадах. Але в Європі XIX ст., в якій уже двісті років тому народномовний друкарський капіталізм переміг латину, максимальне поширення цієї солідарності обмежувалося рамками розуміння народних мов. Інакше кажучи, спати можна будь із ким, але читати можна тільки слова декотрих.

Аристократія, земельне дворянство, фахівці, функціонери й торгівці - оце й були тоді потенційні споживачі плодів філологічної революції. Але ця клієнтура майже ніде не була повністю охопленою, й комбінації реальних споживачів значно відрізнялися залежно від регіону. Щоб зрозуміти чому, треба пригадати основну відмінність між Європою й Америками, встановлену нами. На американському континенті існував майже досконалий ізоморфізм між простором, який займали різні імперії, та поширенням їхніх народних мов. В Європі, однак, такі співпадіння траплялися рідко, а внутрішньоєвропейські династичні імперії були у своїй 
юспові багатомовними. Інакше кажучи, влада й друкована мова покривали різні простори.

Загальне зростання освіченості, торгівлі, промисловості ï державного апарату, характерне для ХІХ ст., створило нові потужні імпульси для народномовної лінгвістичної уніфікації в межах кожної з династичних держав. Латина була црржавною мовою Австро-Угорщини ще на початку 1840-х рюків, але невдовзі після цього зникла майже вмить. Навіть liлишшаючись державною, вона вже не могла в XIX ст. бути мовою бізнесу, науки, преси чи літератури, тим паче в світі, цс ці мови взаємно проникали одна в одну.

Тим часом, народні державні мови здобували дедалі більший статус і вагу в процесі, який, принаймні напочатках, здебілышого не був запланованим. Таким чином англійська моiii витиснула гельську з білышої частини Ірландії, французька загнала в кут бретонську, а кастильська звела катаıнську до рівня маргінальної мови. В таких державах, як І ританія й Франція, де з цілком сторонніх причин у середині ( юлліття відзначалося відносно повне співпадіння державної мови й мови населення ${ }^{26}$, згадане вище взаємопроникнення м1)1 не викликало серйозних політичних наслідків. (Ці випіццки, мабуть, найближчі до американського досвіду.) У баiттьох інших державах, з яких Австро-Угорщина, мабуть, є 'ћіметрально протилежним прикладом, наслідки неминуче иули вибуховими. В її величезних хитких володіннях із багаюммовним, але дедалі освіченішим населенням, заміна латини $(\eta \mu)$-якою народною мовою в середині XIX ст. надавала ш'летенських переваг тим підданим, які вже вживали цю пруковану мову, й виглядала, відповідно, загрозливо для усіх ішиих. Я наголошую на слові будь-якою, адже, як ми деІа./ьніше розглянемо далі, піднесення в XIX ст. статусу німюцької мови при німецькому, на думку декого, дворі Габс-

\footnotetext{
${ }^{26}$ Як ми вже бачили, вернакуляризація державних мов у цих двох дер4. 1ніх розпочалася досить рано. У випадку зі Сполученим Королівством, поI ॠжІи гми сприятливими факторами стало військове підкорення кельтсько41»!юї частини Ірландії [Gaeltacht] на початку XVIII ст. й голод 1840-х.
} 
бургів, не мало нічого спільного з німецьким націоналізмом. (За таких обставин можна було б очікувати, що свідомий націоналізм у кожній династичній державі виникатиме найпізніше серед читачів, для яких офіційна мова є рідною. I ці очікування однак не підтверджуються історичними даними.)

Якщо говорити про клієнтуру наших лексикографів, немає, отже, нічого дивного в тому, що залежно від різних політичних умов існували різні групи споживачів. В Угорщині, приміром, де мадярської буржуазії практично не існувало, але кожний восьмий претендував на аристократичний статус, редути друкованої угорської мови від наступу німецької захищали представники дрібної знаті й збіднілого земельного дворянства ${ }^{27}$. Те ж саме можна сказати й про польських читачів. Більш типовою, однак, була коаліція дрібного дворянства, вчених, професіоналів і бізнесменів, де перші нерідко постачали "високопоставлених" лідерів, другі й треті міфи, поезію, газети й ідеологічні формулювання, а останні гроші й ринкові можливості. Кораес люб'язно пропонує нам симпатичну замальовку ранньої клієнтури грецького націоналізму, серед якої переважали інтелектуали й підприємці":

В тих містах, що були не такі бідні, що мали кількох заможних мешканців і декілька шкіл, а отже якесь число осіб, котрі вміли, принаймні, читати й розуміти древніх авторів, революція розпочалася раніше й прогресувала швидше й плинніше. В деяких із цих міст вже розширюються школи, й там запроваджують вивчення іноземних мов і навіть тих наук, які вивчаються в Європі [sic]. Заможні сприяють друкуванню книжок, перекладених з італійської, французької, німецької й англійської мов; вони своїми коштами відправляють до Європи юнаків, що прагнуть вчитися; дають крашу освіту своїм дітям, включаючи й дівчат...

${ }^{2 i}$ Hobsbawm. The Age of Revolution, p. 165. Прекрасний детальний розгляд можна знайти в: Ignotus, Hungary, pp. 44-56; також: Jaszi. The Dissolution, pp. 224-225.

${ }^{28}$ Kedourie. Nationalism in Asia and Africa, p. 170. Виділено нами. Все тут $є$ типовим. Якшо Кораес і поглядає на “Європу", то через плече; перед 
3 плином часу, читацькі коаліції, чий склад мінявся в діапазоні від угорців до греків, виникали подібним чином про-

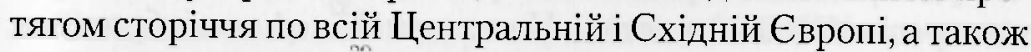
на Близькому Сході ${ }^{2}$. Ступінь участі міських і сільських мас у нових мовно уявлених спільнотах був, природньо, досить різним. Багато залежало від стосунків між цими масами й місіонерами націоналізму. На одному полюсі можна, мабуть, поставити Ірландію, де вирішальну посередницьку роль відіграло селянського походження й близьке до селянства католицьке духовенство. Іншу крайність демонструє іронічний коментар Хобсбоума про те, що: "Галицькі селяни чинили опір польським революціонерам 1846 року, хоч ті й проголошували ліквідацію кріпацтва, воліючи натомість вирізувати шляхту й покладатись на імператорських чиновників" Але скрізь із зростанням письменності ставало дедалі легше здобувати народну підтримку, коли маси відкривали для себе велич говірок, якими вони здавна скромно користувалися, піднесених на рівень друкованих мов.

У цьому смислі привабливе формулювання Нейрна $є$ до певної міри слушним: "Новий середній клас націоналістичної інтелігенції мав запросити до історії народні маси; і запрошення мало бути написане мовою, яку ті розуміли"з1. I Гроте нелегко буде збагнути, чому ж це запрошення виявилося таким принадним і чому настільки різні коаліції спромоглися його видати (нема сумніву, що Нейрнова інтелігенція середнього класу не була тут єдиним господарем), поки ми нарешті не звернемося до проблеми піратського копіювання.

Хобсбоум зауважує, що "Французька Революція не була здійснена чи керована ні партісю або рухом в сучасному сенсі, ані людьми, які намагалися втілити якусь послідовну

()чима в нього Константинополь. Османська ще не $є$ іноземною мовою. А пепрацюючі майбутні дружини долучаються до друкарського ринку.

${ }^{29}$ Для прикладів див.: Seton-Watsoп. Nations and States, pp. 72 (Фінляндія), 145 (Болгарія), 153 (Богемія), 432 (Словаччина); Kohп. The Age of Nationalism, pp. 83 (Сгипет) and 103 (Персія).

The Age of Revolution, p. 169.

${ }^{31}$ The Break-up of Britain, p. 340. 
програму. Вона навіть не висунула серйозних “лідерів" того типу, до якого нас призвичаїли революції XX ст., аж до появи постреволюційної постаті Наполеона” . Але відбувшись, вона увійшла до сукупної пам'яті друку. Сплетіння незліченних і бентежних подій, пережитих їі творцями й жертвами, стало "річчю" - причому з власною назвою: Французька Революція. Наче величезна безформна кам'яна брила, перетворена міріадами краплин води у заокруглений валун, peальний досвід під дією мільйонів друкованих слів сформувався в "концепт" на друкованому аркуші, а згодом й у модель. Чому “вона” вибухла, на що “вона” була спрямована, що стало "іi”" успіхом або поразкою, все це становило теми безконечних дискусій ї̈ прихильників і опонентів: проте ніхто не ставив під сумнів їі, так би мовити, "оречевлення ${ }^{-33}$.

Подібним же чином, як тільки почала з'являтися друкована інформація про рухи за незалежність на американському континенті, вони відразу ж перетворились у "концепти", “моделі" й навіть “проекти”. В “дійсності” ж, страх Болівара перед негритянськими заколотами й заклик Сан Мартіна до своїх тубільців ставати перуанцями хаотично стикалися. Проте, друковане слово швидко призабуло острахи Болівара, якщо коли про них і згадували, то лише як про недоречну аномалію. Американський сумбур, власне, й породив ці уявлені реалії: національні держави, республіканські інституціі, спільні громадянства, народний суверенітет, національні прапори й гімни тощо, ліквідувавши заодно їхні концептуальні протилежності династичні імперії, монархічні інституції, абсолютизм, підлеглість, спадкову аристократію, кріпосне право, всілякі гетто й таке інше. (В цъому контексті найприголомшуючото була загальна "елізія" масового рабовласництва із "взірцевих" CША XIX ст. та із спільної мови "взірцевих" Південних респуб-

${ }^{32}$ The Age of Revolution, p. 80.

33 Порівняймо: “Сама назва Промислової Революції віддзеркалює іiі порівняно запізнілий вплив на Європу. Ця річ [sic] існувала в Британи раніше від назви. Англійські й французькі соціалісти - самі по собі безпрецедентне угрупування - винайшли ії не раніше $1820-\mathrm{x}$ років, можливо, по аналогії з політичною революцією у Франці1. Ibid., p. 45. 
лік.) До того ж, вагомість і повторюваність проекту підтверджувалась, безсумнівно, численністю незалежних держав.

Таким чином, вже в другому десятилітті XIX ст., як не раніше, "модель" незалежної національної держави стала доступною для копіювання ${ }^{34}$. (Першими групами, що вдали('я до нього, були маргінальні коаліції інтелектуалів, об'єднаІих довкола рідної мови, про які йшлося в цьому розділі.) 'la саме тому, що це вже була відома модель, вона нав'язувала "евні “стандарти", надто явні відхилення від яких були неприпустимі. Навіть відстале й реакційне угорське та поль'ьке дворянство було просто змушене для вигляду “видавати :апрошення” (хай тільки не далі як до кухні) своїм пригнобленим співвітчизникам. Тут, якщо хочете, спрацьовувала логіка перуанізації Сан Мартіна. Коли вже "угорці" заслугопували національної держави, то йшлося про всіх угорців ${ }^{33}$; іплося про державу, в якій кінцевою метою суверенності мала бути спільність тих, хто говорить і читає угорською мовою; а згодом до цього додавалася ліквідація кріпосного прања, впровадження народної освіти, розширення виборчих "рав і так далі. Таким чином "популістський" характер ран॥іх европейських націоналізмів, навіть під демагогічним проводом найвідсталіших соціальних груп, був глибший, ніж Ila американському континенті: кріпацтву мусив настати кінець, легалізоване рабство було неприпустимим - не в оспиню чергу тому, що концептуальна модель їх не передбачала.

${ }^{34}$ Точніше було б, мабуть, сказати, що ця модель була складною суміш॥1ю французьких і американських елементів. Проте "очевидними реаліими" Франції до 1870 р. були реставровані монархії й сурогатна динасичність Наполеонового двоюрідного небожа.

35 Хоча це й не було чітко визначеним питанням. Половина підданих ' мюњляла мадярською. На початку ХІХ ст. виша мадярська аристократія юзмовляла французькою або німецькою; середнє й нижче дворянство "гाілкувалося спотвореною латиною впереміш із мадярськими та слоніцькими, сербськими й румунськими виразами, а також розмовною нім'цькою..." Ignotus. Hungary, pp. 45-46 and 81. 


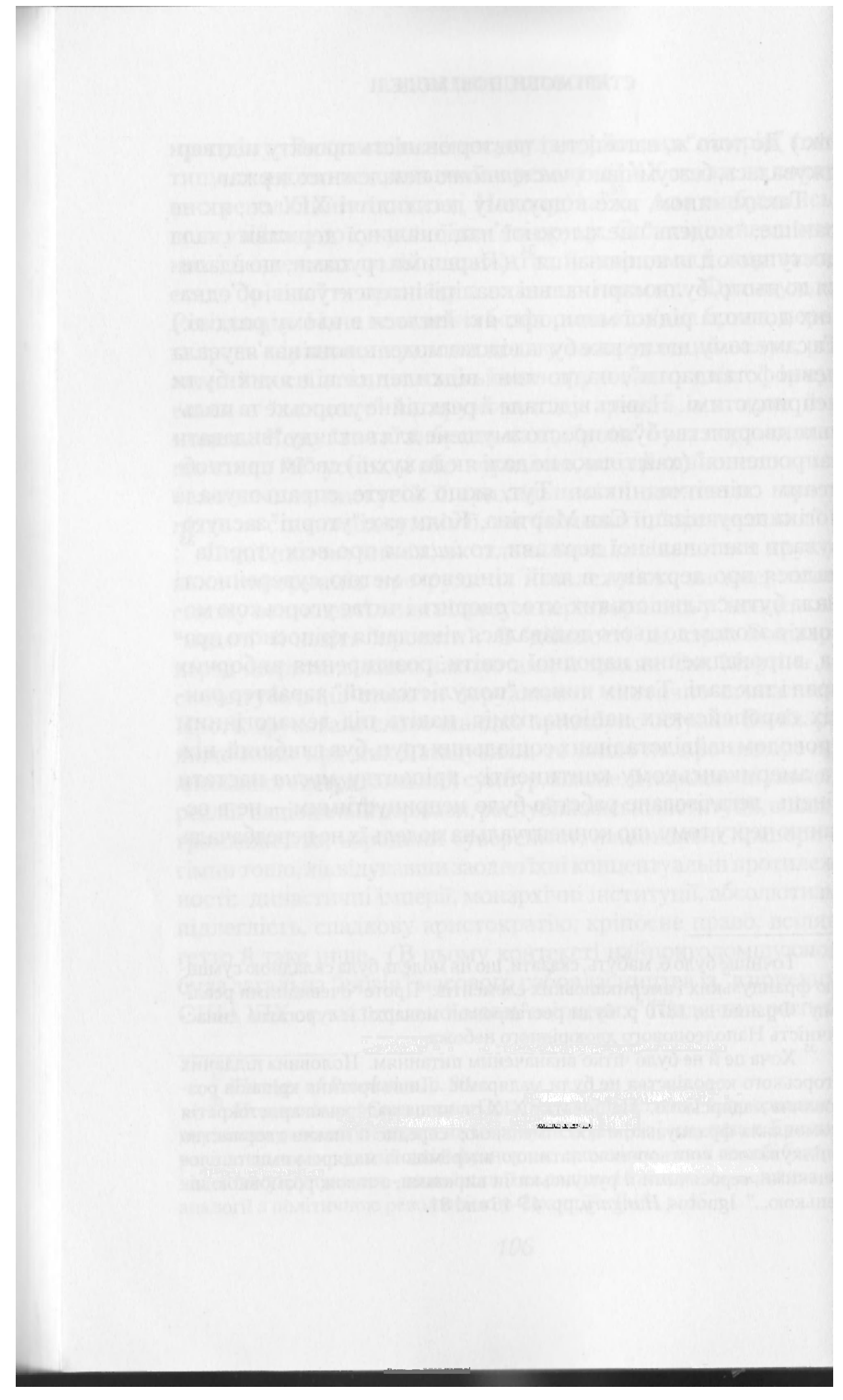




\section{Офіційний націоналізм та імперіалізм}

Протягом XIX ст., особливо другої його половини, філологічно-лексикографічна революція й піднесення внутрішII,оєвропейських національних рухів, самих по собі продукгів не лише капіталізму, але й елефантіазу династичних держав, творили все більші культурні, а отже й політичні проблеми для багатьох династичних правителів. Адже, як ми бачили, фундаментальна легітимність більшості з цих динасriй зовсім не була пов'язана з національним питанням. Ромаиови панували над татарами й латишами, німцями й вірменамı, росіянами й фінами. Габсбурги височіли над мадярами ii хорватами, словаками й італійцями, українцями й австрій‘ькими німцями. Ганноверська династія правила бенгальцями й мешканцями Квебеку, а також шотландцями й ірландщямми, англійцями й валлійцями . До того ж, на континенті

${ }^{1}$ Цікаво, ццо на чолі того об'єднання, яке врешті-решт перетворилось v Британську імперію, від початку ХІ ст. не стояла власне "англійська" лниастія: відтоді королівський трон бачив строкату процесію норманів ( ІІлантагенети), валлійців (Тюдори), шотландців (Стюарти), голландців (Оранська династія) й німців (Ганноверська династія). Нікого це не І урбувало аж до філологічної революції й пароксизму англійського піціоналізму в Першій світовій війні. Віндзорська династія звучить так ıамо дивно, як "шонбрунська“ або "версальська" династії. 


\section{УЯВЛЕНІ СПІЛЬНОТИ}

члени одних і тих самих династичних сімейств нерідко правили різними, часом ворожими державами. До якої національності можна було б віднести Бурбонів, що правили Францією й Іспанією, Гогенцоллернів - Пруссією й Румунією, Віттельзбахів - Баварією й Грецією?

Ми також бачили, що з суто адміністративних міркувань ці династії, хто швидше, хто повільніше, закріпляли за певними друкованими мовами статус державних - причому, “вибір" мови був, у принципі, питанням традиційності або просто зручності.

Лексикографічна революція в Європі, однак, народила й поступово поширила переконання в тому, що мови (при-

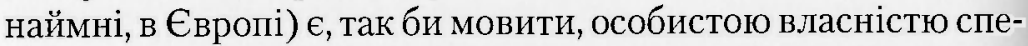
цифічних груп - тих, хто ними щоденно розмовляє й читає на них - i що цим групам, уявленим як спільноти, належить автономне місце в товаристві рівних. Таким чином ці філологічні підбурювачі поставили династичних правителів перед прикрою дилемою, яка з часом тільки загострилася. Ніде ця дилема не вимальовується так чітко, як у прикладі 3 Австро-Угорщиною. Коли просвіщенний абсолютист Йсиф II вирішив на початку 1780-х поміняти державну мову 3 латинської на німецьку, "він не боровся, скажімо, з мадярською мовою, а тільки з латиною... Він міркував, що при аристократичному правлінні, заснованому на середньовічній латині, не можливо ефективно діяти в інтересах народних мас. Потреба спільної мови, яка б пов'язала всі частини його імперії, здавалась йому незаперечною. Ця потреба не могла його привести до вибору будь-якої іншої мови, крім німецької, єдиної, якій належали серйозні культурні й літературні здобутки та якою користувалася численна меншина в усіх його провінціях" ". I справді, “Габсбурги не були свідомою й послідовною германізаторською владою... Були такі

${ }^{2}$ Jaszi. The Dissolution, p. 71. Цікаво, шо Йосиф відмовився скласти коронаційну присягу в якості короля У горшини, бо це зобов'язало б його вшановувати "конституційні" привілеї мадярської аристократії. Ignotus. Hungary, p. 47. 


\section{ОФІЦЙНИЙ НАЦІОНАЛІЗМ ТА ІМПЕРІАЛІЗМ}

Габсбурги, що навіть не розмовляли німещькою. Навіть ті Іабсбурзькі імператори, що іноді заохочували політику гермінізації, не керувались у своїх зусиллях жодними націоналістичними поглядами, а їхні заходи були продиктовані намірами досягнення уніфікації й універсальності власної імпеpiі $i^{\prime 2}$. Вони ставили собі за мету здобуття “домашньої влади", I lausmacht. Однак, починаючи від середини дев'ятнадцятого 'торіччя, німецька мова почала поступово набувати подвійиого статусу: "загально-імперського" і "специфічно-націонільного". Чим активніше династія нав'язувала німецькій мові цю їі загальну роль, тим більше створювалося враження пі/тримки нею своїх німецькомовних підданих, і тим швидше зростала нехіть із боку всіх інших. Проте варто було їй меншувати цей тиск, тим паче робити поступки іншим мопім, перш за все угорській, як не тільки сповільнялась уні中ікація, але й німецькомовні піддані відразу почували себе - кривдженими. Отож виникала загроза, що ії зненавидять илиочасно й за відстоговання німців, і за їх зраду. (Подібним 'ІІиом Османи стали об'єктом ненависті з боку турецькомовного населення як відступники, а з боку нетурецькомовного - як ті, хто займався примусовим потуреченням.)

Оскільки всі династичні правителі середини століття "'яною мірою використовували народну мову як державну" 1 також завдяки стрімко зростаючому в усій Свропі престижу пиціональної ідеї, в середовищі євро-середземноморських мюнархій стала проявлятися помітна тенденція обережного просування в напрямку принадної національної ідентифікіції. Романови раптом виявили, що вони великороси, пред'"авники Ганноверської династії стали англійцями, Гогениюллерни німцями - а їхні родичі з дещо більшими трудно-

${ }^{3}$ Ibid., p. 137. Виділено нами.

Можна доводити, шо 1844 рік ознаменував собою завершення трин.лої доби, коли мадярська мова зрештою замінила латину в якості деркінзнї в Угорському королівстві. Проте, як нам відомо, спотворена латина илишалася, фактично, мовою спілкування мадярської середньої й нижчої แ1:เті пе в XIX ст. 


\section{УяВЛЕНІ СПІЛЬНОТИ}

щами перетворилися в румунів, греків тощо. 3 одного боку, ці нові ідентифікації підтримували легітимність, якіӥ, в добу капіталізму, скептицизму й науки, було все важче безпечно спиратися лише на удавану сакральність та древність. '3 другого ж боку, вони створювали нові загрози. Якщо кайзер Вільгельм II оголошував себе “німцем №1", цим самим він непрямо визнавав, що був одним із багатьох иому подьбних, що мав представницьку функцію, а отже, в принципі, міг стати й зрадником своїх побратимів-німців (чого не можна було б навіть уявити в часи розквіту династій. Зрадником кого або чого?). Після катастрофи, що спіткала Німеччину 1918 року, його, так би мовити, спіймали на слові. Ціючи в ім'я німецької нації, цивільні політики (публічно) и генеральний Штаб (із звичною відвагою, секретно) випровадили його 3 батьківщини до відлюдного голландського передмістя. Також і Мохаммед-Реза Пехлеві, проголосивши себе не просто шахом, а шахом Ірану, був згодом затаврований як зрадник. Те, що він сам погодився, нехай не з вердиктом, але. так би мовити, з юрисдикцією національного суду, підтверджується комічною сценою, розіграною в момент його відправки у вигнання. Перш ніж піднятися до свого літака, він поцілував перед фотографами землю й оголосив, що бере з собою дрібку святої іранської землі. Це вже кінокадр із фільму про Гарібальді, а не про Короля Сонця .

"Натуралізація" європейських династій - маневри, що часто складалися 3 акробатичних елементів вищого пілотажу - зрештою привела до того, що Сетон-Вотсон дошкульно назвав "офіційними націоналізмами", чи не найкрацим прикладом яких є царська русифікація. Ці "офіційні націоналізми" найкраще розуміти як намагання поєднати нату-

5 Від професора Чегабі з Гарвардського університету я довідався, що шах насамперед імітував свого батька, Резу Пехлеві, котрий, висланий 194 року. .с ндоном на острів Маврикій, взяв із собою трохи ірансько землі.

Seton-Watson. Nations and States, p. 148. На жаль, ця дошкульністы обмежується тільки Східною Європою. Сетон-Вотсон слушно виявля свою уїдливість по відношенню до династії Романових і радянськојо режиму, ал е не помічає. як подібної ж політики дотримувались у Јондоні Парижі, Берліні, Мадриді й Вашингтоні. 


\section{ОФІЦІЙНИЙ НАЦІОНАЛІЗМ ТА ІМІІЕРІАЛІЗМ}

ралізацію зі збереженням династичної влади, зокрема над величезними багатомовними територіями, накопиченими від часів середньовіччя, інакше кажучи, як спроби натягнути коротку й цупку шкіру нації на гігантське тіло імперії. "Русифікація" різношерсної маси царських підданих являла собою таким чином насильницьке й свідоме зчеплення докупи двох протилежних політичних устроїв - давнього й цілком нового. (Хоча й існує певна аналогія зі, скажімо, іспанізацією американського континенту й Філіппін, залишасться одна суттєва різниця. Дії культурних конкістадорів царизму кінця XIX ст. були продиктовані усвідомленим мак'явеллізмом, тоді як їхні іспанські попередники XVI ст. керувались неусвідомленим повсякденним прагматизмом. До того ж вони насправді не вважали це "іспанізацією” - радше звичайним павертанням язичників і дикунів).

Щоб вірно визначити місце "офіційного націоналізму" рішучого злиття нації й династичної імперії - необхідно пам'ятати, що він поширився пізніше та як реакція на масові иаціональні рухи, розповсюджені в Свропі після 1820 -х років. Якщо ці націоналізми брали за зразок американську й французьку історії, то тепер вони самі стали взірцями для моделювання ${ }^{7}$. Потрібен був лише якийсь вигадливий фокус, щоб дати імперії змогу привабливо виглядати в національному вбранні.

Щоб охопити з певної перспективи ввесь цей процес вторинного копіювання моделі, корисно було б розглянути деякі аналогічні, але досить контрастні приклади.

Сетон-Вотсон чудово показав, як незручно почувала себе аристократія династії Романових, уперше "виходячи на вулиці”" . Як зазначалося раніше, у XVIII ст. придворною мовою Санкт-Петербурга була французька, тоді як більшість Іровінційних вельмож користувалась німецькою. Після

\footnotetext{
${ }^{7}$ Повчальною $є$ аналогія з політично-військовими реформами Шарнхорста, Клаузевіца й Гнейзенау, які у свідомо консервативному дусі пристосували ряд стихійних нововведень Французької Революції для побудови великої, професійно вкомплектованої, постійної, призивної армії XIX ст.

${ }^{8}$ Ibid., pp. 83-87.
} 


\section{УяВЛЕНІ СІІЛЬНОТИ}

наполеонівського вторгнення граф Сергій Уваров запропонував у офіційному рапорті 1832 року, щоб в основу держави було покладено три принципи - Самодержавство, Православ'я та Народність. Якщо перші два принципи були старими, то третій виявився цілком новим - і дещо передчасним у добу, коли половина "нації" досі складалася з кріпаків, а для більшої половини російська мова не була рідною. Рапорт Уварова допоміг йому здобути посаду міністра освіти, але не більше того. Ще півстоліття царизм опирався спокусам Уварова. Лише під час правління Олександра III (18811894) русифікація стала офіційною політикою династії: значно пізніше від появи в межах імперії українського, фінського, латиського й інших націоналізмів. За іронією долі перші русифікаторські заходи були здійснені саме проти тих “національностей”, що були найбільш Kaisertreu - таких, як балтійські німці. В 1887 р. в прибалтійських провінціях російська стала обов'язковою мовою навчання в усіх, окрім початкових, класах державних шкіл, а згодом цю вказівку було поширено й на приватні школи. В 1893 р. був закритий Дерптський університет, один із найповажніших навчальних закладів імперії, через те, що в його аудиторіях вживали німецьку мову. (Пригадаймо, що перед цим німецька була провінційною державною мовою, а не речником масового національного руху.) I так далі. Сетон-Вотсон наважується навіть висловити думку про те, що революція 1905 року була “революцією неросіян проти русифікації не меншою мірог, ніж революцією робітників, селян і радикальних інтелектуалів проти самодержавства. Ці два бунти були, безсумнівно, взаємопов'язані: фактично, соціальна революція розгорталась найгостріше в неросійських регіонах, де їі підтримували польські робітники, латвійські хлібороби й грузинські селяни".

Водночас великою помилкою було б припускати, що раз русифікація була династичною політикою, значить вона не здійснила один із найголовніших своїх намірів - наблизити до трону зростаючий “великоруський” націоналізм. Причо-

\footnotetext{
${ }^{9}$ Ibid., p. 87.
} 
му, керуючись не тільки почуттями. Адже великі можливості відкривалися перед російськими чиновниками і підприємцями завдяки величезній бюрократії й обширному ринку, иаданих імперією.

Не менш цікавою, ніж Олександр III, всеросійський царрусифікатор, постає його сучасниця Вікторія фон СаксеКобург-Гота, королева Англії ma, наприкінці життя, імператриця Індії. Власне, її титул становить більший інтерес, аніж її особа, адже він символізує міцність спайки між нацією il імперією ${ }^{10}$. Ї̈і правління також ознаменовується початком "офіційного націоналізму" в лондонському стилі, який виявляє очевидну спорідненість із русифікацією, запровадженою в Санкт-Петербурзі. Цю спорідненість добре оцінювати метоцом, так би мовити, порівняння географічної довготи.

у “Розпаді Британій Том Нейрн ставить питання, чому паприкінці XVIII ст. не існувало шотландського націоналістичного руху, незважаючи на ріст шотландської буржуазії й паявність досить високопоставленої шотландської інтелі'енціï ${ }^{11}$. Хобсббоум безапеляційно спростував серйозні розмірковування Нейрна таким зауваженням: "Чистісіньким :нахронізмом було б очікувати в той час [з боку шотландців]

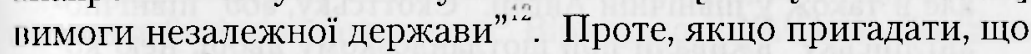
Бенджаміи Франклін, один із тих, хто підписав американську Декларацію незалежності, народився за п'ять років до Девіда ІОма, можна схилитися до думки, що якраз це судження й $\epsilon$ дещо анахронічним ${ }^{13}$. Мені здається, що проблему - та її иирішення - треба шукати деінде.

${ }^{10}$ Ця спайка руйнується в процесі історичного переходу від Бригапської Імперії до Британської Співдружності, тоді просто до Співлуужності, тоді до...?

${ }^{11}$ The Break-up of Britain, pp. $106 \mathrm{ff}$.

12 "Some Reflections", p. 5.

${ }^{13}$ В книзі з показовою назвою "Винайдення Америки: Декларація щезалежності Джефферсона" Гері Вілс доводить, фактично, що нашіоналістичне мислення Джефферсона було в цілому сформоване не Локом, а I()мом, Хатчісоном, Адамом Смітом та іншими світилами шотландського щросвітництва. 


\section{УЯВЛЕНІ СПІЛЬНОТИ}

3 іншого боку, Нейрн виявляє типову націоналістичну тенденцію до трактування своєї "Шотландії" як чогось безсумнівного й споконвічного. Блок нагадує нам про непевне походження цієї "сутності", зауважуючи, що спустошення, вчинені датчанами й Вільгельмом Завойовником, назавжди зруйнували культурну гегемонію Північної англо-саксонської Нортумбрії, символами якої були такі світила, як Алквін і Беда ${ }^{14}$ :

Частина північного регіону була назавжди відірвана від власне Англії. Відгороджені від решти англосаксів поселеннями вікінгів у Йоркширі, мешканці низин навколо нортумбрської цитаделі Едінбурга опинилися під владою кельтських повелителів гір. Таким чином, двомовне королівство Шотландії виникло певною мірою в результаті скандинавських вторгнень.

А Сетон-Вотсон, зі свого боку, пише, що шотландська мова ${ }^{15}$ :

утворилася внаслідок злиття саксонської й французької мов, хоча з меншою долею останньої та з більшими запозиченнями з кельтських і скандинавських джерел порівняно з півднем. Цією мовою розмовляли не тільки на сході Шотландії, але й також у північній Англіі. Скоттську, або "північноанглійську" вживали при шотландському дворі, нею користувалася еліта (яка також могла розмовляти й гельською мовою), а також все населення Шотландської низовини. Це була мова поетів Роберта Генрісона й Вільяма Данбара. Вона цілком могла розвинутися в окрему літературну мову модерної доби, якби унія 1603 року між двома королівствами не принесла панування південноанглійської мови завдяки ії поширенню на двір, в адміністрацію й вищі верстви ШШотландії.

Ключовим моментом тут $€$ те, що вже на початку XVII ст. значна частина того, що колись стане мислитися Шотландією, була англомовною, що за умови бодай мінімального рівня письменності надавало безпосередній доступ до друкова-

\footnotetext{
${ }^{14}$ Feudal Society, I, p. 42.
}

${ }^{15}$ Nations and States, pp. 30-31. 
иої англійської мови. Згодом, на початку XVIII ст., мешканці англомовної низовини спільно з Лондоном взяли участь у ирактичному винищенні кельтської мови (Гельтахту). В "бох випадках жодна свідома англізація не переслідувалася, иона виявилася побічним продуктом. Але поєднавшись, обидва процеси задовго до ери націоналізму цілковито виключили будь-яку можливість виникнення націоналістичного руху європейського типу, грунтованого на мовній спільності. ' Іому не виник націоналізм американського типу? Частково па це відповідає Нейрн, говорячи між іншим про "масову іптелектуальну міграцію" на південь, починаючи від середини XVIII ст. . Проте справа не обмежувалась інтелектушльною міграцією. ІШотландські політики переселялися на ıівдень займатися законодавством, а шотландські бізнесмени мали відкритий доступ до лондонських ринків. Факггчно, цілком на відміну від Тринадцяти Колоній (і меншою мірою від Ірландії), не існувало жодних бар'єрів на шляху цих ॥аломників до центру. (Порівняйте з відкритою дорогою до Відня, що стелилася перед латино- й німецькомовними угорı цми у XVIII ст.). Англійська џе не стала мовою "англійців".

До подібного висновку можна прийти, розглянувши це шитання й під іншим кутом. Вірно, що в XVII ст. Лондон почав наново здобувати заморські території, втрачені після катастрофічного завершення Столітньої війни. Але "дух" ıих завоювань ще повністю належав донаціональній добі. Разючим підтвердженням цього є факт, що “Індія" стала "Британською" лише через двадцять років після сходження па трон Вікторії. Іншими словами, до самого повстання 1857 року "Індією" заправляло комерційне підприємництво - не цержава, тим паче не національна держава.

Але наближались переміни. Коли в 1813 р. надійшов час иідновлення статуту Ост-Індської компанії, парламент прижачив щорічне асигнування в розмірі 100,000 рупій на підгр)имку місцевої освіти як "орієнтального", так $i$ "західного"

${ }^{16}$ The Break-up of Britain, p. 123. 
типу. В 1823 р. в Бенгалії почав діяти Комітет народної освіти; а в 1834 р. президентом цього комітету став Томас Бабінгтон Маколей. Заявивши, що “одна-єдина полиця з гарної європейської бібліотеки має більшу вартість, ніж уся література Індії й Аравії" свою сумнозвісну "Записку про освіту" (Minute on Education). Йому пощастило більше, ніж Уварову, адже його рекомендації відразу ж набрали чинності. Почала запроваджуватись цілком англійська освітня система, яка, за власними неповторними словами Маколея, мала створити новий “клас осіб, індійців за кров'ю та кольором шкіри, проте англійців за смаками, думками, мораллю й інтелектом" ${ }^{18}$. У 1836 р. він писав, що :

Жоден індус, отримавши англійську освіту, не залишиться щирим послідовником своєї релігії. В мене немає сумніву [й ніколи не було], що, довівши до кінця наші освітні плани, ми вже через тридцять років не матимемо серед респектабельних бенгальських верств жодного ідолопоклонника

Тут, безперечно, присутній певний наївний оптимізм, який нагадує нам Ферміна в Боготі за півстоліття до того. Але важливим $є$ те, що перед нами постає довгострокова (30 років!) політика, свідомо сформульована й запроваджена з метою обернути "ідолопоклонників" не стільки в християн, скільки в людей англійської культури, попри невиправний колір іхньої шкіри й походження. Цей проект такого собі ментального схрещування, яке, в порівнянні із запропонованим Ферміном фізичним схешуванням, доводить, що цілком в дусі вікторіанської епохи імперіалізм став значно вишуканіпгим. У будь-якому випадку можна впевнено ствер-

\footnotetext{
${ }^{17}$ Можна бути переконаним, шо цей зарозумілий молодик, англійський Уваров з середнього класу, не був ознайомлений із жодною з цих "місцевих літератур".

${ }^{8}$ Див.: Donald Eugene Smith. India as a Secular State, pp. 337-338; and Percival Spear. India, Pakistan and the West, p. 163.

${ }^{19}$ Smith. India, p. 339.
} 
лжувати, що відтепер на всіх обширах зростаючої імперії ипроваджувався, хоча й нерівномірно, маколізм ${ }^{22}$.

Як і русифікація, англізація також, звісно, обіцяла райлужні перспективи цілим арміям представників середнього класу метрополії (серед яких не останніми були й шотландці!) - чиновникам, учителям, купцям і хліборобам - котрі гтрімко заполонили широкі, завжди сонцесяйні простори коюлівства. Однак існувала значна відмінність між імперіями, ксрованими з Санкт-Петербурга й Лондона. Царська імперія залишалася "суцільним" континентальним володінням, у мсжах помірного й полярного поясів Євразії. Можна було, так бı мовити, перейти з одного їі краю до іншого. Мовна споріднеиість зі слов'янським населенням Східної Свропи й - скажімо так - історичні, політичні, релігійні й економічні зв'язки з ба'атьма неслов'янськими народностями означали, що до певної міри бар'єри на шляху до Санкт-Петербурга не були нездоланпими . Британська імперія, з іншого боку, була безсистемним иабором переважно тропічних володінь, розкиданих по всіх к)нтинентах. Тільки маленька частина підлеглих народностей мала хоч якісь тривалі релігійні, мовні, культурні чи бодай иолітичні й економічні зв'язки з метрополією. Зіставлені поруч під час святкування Ювілейного року, вони нагадували ті безладні колекції робіт старих майстрів, поспіхом зібрані англій('ькими й американськими мільйонерами, які згодом опиняю) гься в офіціозних імперських державних музеях.

Наслідки цього добре проілюстровані гіркими спогадами Бі॥ін Чандра Пала, який у 1932 р., через століття після “Записки” Маколея, все ще обурено писав, як індійські чиновники ${ }^{22}$ :

${ }^{20}$ Див., скажімо, як Рофф незворушно описує заснування 1905 року Куала Кангсарського малайського коледжу, який невдовзі, без жодної іронії, став називатися “малайським Ітоном”. У відповідності з приписами Маколея, студентів туди набирали з "респектабельних верств" - тобто, з середовища догідливої малайської аристократії. Половина першого пабору складалася з прямих нащадків різних малайських султанів. Willian R. Roff. The Origins of Malay Nationalism, pp. 100-105.

${ }^{21}$ Інша справа із зауральськими народностями.

.- Див.: Bipin Chandra Pal. Memories of My Life and Times, pp. 331-332. Виділено нами. 


\section{УЯВЛЕНІ СПІЛЬНОТИ}

не тільки проходили надзвичайно жорстку перевірку на тих самих умовах, шо й британські службовці, але й проводили найкращі роки свого гнацького становлення в Англії. Після повернення на батьківщину вони, фактично, вели життя майже невідрізниме від англійських урядовців, і майже побожно дотримувалися їхніх соціальних умовностей і етичних стандартів. В той час народжений в Індії [sic - згадаймо наших іспаноамериканських креолів] цивільний посадовець практично відокремлював себе від батьківської громади й жив, рухався, перебував у атмосфері, такій милій серџю його британських колег. Способомммсления й манерами він нічим не відрізнявся від будь-якого англійия. Для нього це було значною жертвою, адже таким чином він ставав цілковито відчуженим від громади свіввітчизників, соціально й морально опиняючись серед них у ролі парії... Він був таким самим чужинием на рідній своій землі, що й європейські поселенці цієї країни.

Точно за Маколеєм. Значно серйознішим, однак, було те, що такі чужинці на рідній землі все одно були приречені -3 не меншою невідворотністю, ніж американські креоли - на "ірраціональну" постійну залежність від англійських maturrangos. Яким би англізованим не був бенгалець Пал, доступ до урядових вершин був назавжди закритий для нього. Йому також заборонялося виходити за межі певного периметру - в горизонтальному напрямку, скажімо, до Золотого Берега чи Гонконгу, а у вертикальному до метрополії. Він міг ставати "пілковито відчуженим від громадл свіввітчизників", але все життя був приречений служитл саме серед них. (Хто входив до складу "них", безперечно, змінювалося в міру розширення сфери британських завоювань на субконтиненті) ${ }^{23}$.

${ }^{23}$ Це правда, шо індійські службовці працювали в Бірмі; але Бірма була до 1937 року адміністративною частиною Британської Індії. Індійиі також займали другорядні посади - особливо в поліції - в Британськіі Малайзії та Сінгапурі, проте вони служили як "місцеві" й "іммігранти", тобто без права бути переведеними "назад" до індійської поліції. Зазначмю, що мова йде саме про службовців: індійські робітники, торговці й навіт\% 


\section{ОФІЦІЙНИЙ НАЦІОНАЛІЗМ ТА ІМПЕРІАЛІЗМ}

Згодом ми ще розглянемо вплив цих офіційних націоналізмів на ріст азіатських і африканських націоналізмів XX ст. 'уу лише підкреслимо, шо внаслідок англізації по всьому ''віту з'явилися тисячі таких Палів. Це нам яскраво демон'трує фундаментальне протиріччя англійського офіційного ніціоналізму, а саме внутрішню несумісність імперії й нації. : гавмисно кажу “нації”, адже завжди виникає спокуса звипуватити в появі цих численних Палів расизм. Жодна твереимисляча особа не заперечить глибоко расистський харакще) англійського імперіалізму XIX ст. Проте Пали також жнували і в білих колоніях - Австралії, Новій Зеландії, Канаді й Південній Африці. Там теж була сила-силенна .пюлійських і потландських учителів, i англізація також була нультурною політикою. Як і для Пала, для них теж була шцоступною звивиста дорога вгору, яка ще була відкрита шแтландцям у XVIII ст. Англізовані австралійці не служили " Цуубліні чи Манчестері, або хоча 6 в Оттаві чи Кейптауні. Ilс могли вони, аж до останнього часу, й займати посаду гещщ.)ал-губернаторів у Канберрі ${ }^{2-}$. Це було дозволено тільки "шглійським англійцям", тобто представникам напівприхониної англійської нації.

За три роки до того, як Ост-Індська компанія втратила ıше "мисливське угіддя" в Індії, командор Перрі зі своєю и())юю флотилією безапеляційно розтрощив стіни, за якими ı к довго перебувала у самонав'язаній ізоляції Японія. Після 1 1 .54 року самовпевненість і внутрішня легітимність бакуфу ( жжиму сегунату Токугави) були стрімко підірвані явною інг безпомічністю перед загрозою проникнення Заходу. Із и:кликом "Sonпо Joi" (пана імператору, геть варварів!), и'зеличкий загін самураїв середнього рангу, переважно 3

|кхізці переміщалися в чималих кількостях до британських колоній у ПІиценно-Східній Азії, Південній та Східній Африці й навіть у регіоні К.минського моря.

. Звичайно, наприкінці едвардіанської доби декілька “білих жителів แм/юній” таки мігрували до Лондона й стали членами парламенту або Іщиначними газетними королями. 
таких регіонів (han), як Сацума й Чосю, остаточно скинули його 1868 року. Серед причин їхнього успіху можна назвати надзвичайно творче засвоєння, особливо після 1860 року, нової західної воєнної науки, систематизованої від 1815 року прусськими й французькими штабними кадровиками. Таким чином вони зуміли ефективно використати 7,300 найсучасніших гвинтівок (в основному залишків після американської громадянської війни), закуплених у англійських торговців зброєю". "У володінні рушницями...воїни з Чосю виявляли таку майстерність, що хвацькі старі методи “ріж і рубай" були проти них абсолютно марними" ${ }^{2}$.

Опинившись, однак, при владі, бунтівники, яких ми нині пам'ятаємо в ролі олігархів Мейдзі, виявили, що їхня війсь-

${ }^{25}$ Ключовою постаттю тут був Омура Масуджіро (1824-1869), так званий "Батько японської армії". Незнатного походження самурай із Чосю, він розпочав свою кар'єру, вивчаючи західну медицину за голландськими посібниками. (Треба пам'ятати, шо до 1854 року голландці були єдиними представниками Заходу, яким був дозволений доступ до Японії, й цей доступ, по суті, обмежувався островом Десімою, вдалині від контрольованого Бакуфу порту Нагасакі.) Закінчивши в Осаці Текіджюку, найкращий тоді голландськомовний навчальний заклад країни, він повернувся додому, де займався лікарською практикою - проте без особливих успіхів. У 1853 р. він отримав посаду викладача західних дисциплін в Уваджімі, а тоді раптом переселився до Нагасакі вивчати мореплавство. (На основі письмових посібників він запроектував і наглядав за будівництвом першого японського пароплава.) Його час настав після прибуття Перрі; 1856 року він переїхав до Едо, де працював викладачем майбутньої Національної військової Академії та дослідником західних текстів у вишому дослідному центрі бакуфу. Він прославився завдяки своїм перекладам європейських праць із військової теорії, особливо щодо стратегічних і тактичних нововведень Наполеона, й отримав 1860 року виклик у Чосю служити військовим дорадником. У $1864-1865$ рр. він успішно відслужив командиром під час громадянської війни в Чосю, довівши тим самим доречність своїх перекладів. Пізніше він став першим міністром війни Мейдзі, розробивши для цього режиму революційні плани загальної військової повинності й ліквідації самураїв як легальної касти. За ці свої старання він і був віроломно вбитий розлюченим самураєм. Див.: Albert M. Craig. Choshu in the Meiji Restoration, особливо стор. 202-204, 267-280.

${ }^{26}$ Японський спостерігач-сучасник, цитований у: Е. Herbert Normaп. Soldier and Peasant in Japan, p. 31. 
кова доблесть не гарантує автоматично політичної легітимпості. Якщо Тенно ("Імператора") можна було швидко реставрувати скасуванням бакуфу, то виганяти варварів виивилося значно складнішою справою ${ }^{21}$. Геополітична безшека Японії залишалася такою ж крихкою, що й перед 1868 р. Одним із найголовніших засобів зміцнення внутрішньої позиції олігархії став, таким чином, різновид "офіційного націопалізму" середини століття, досить свідомо запозичений із "руссько-німецької моделі Гогенцоллернів. Між 1868 і 1871 рр. були розпущені всі залишкові місцеві “феодальні" ıійськові підрозділи, і в руках Токіо було зосереджено централізовану монополію на засоби насильства. В 1872 р. імперським рескриптом наказувалося сприяти загальній освіченості серед дорослих чоловіків. У 1873 р., раніше ніж у Сполученому Королівстві, Японія запровадила військову повин॥ість. Одночасно режим ліквідував самураїв як легально шизначену й привілейовану верству, що було істотним кроком не тільки для того, щоб офіцерський корпус ставав (повільно) доступним для всіх талантів, але й для повнішої відиовідності “наявній" тепер моделі громадянської нації. я понське селянство звільнилося від підлеглості феодальній han-системі й відтепер безпосередньо експлуатувалося лержавою й аграрно-комерційними землевласниками ${ }^{28}$. 13 1889 р. настала черга конституції прусського типу, а згодом і загального виборчого права для чоловіків.

В цій організованій кампанії діячам Мейдзі допомогли три напіввипадкові фактори. Першим був відносно високий рівень японської етнокультурної однорідності, наслідок двох

${ }^{27}$ Вони це знали з власного гіркого досвіду. В 1862 р. англійська ескідра стерла з лиця землі половину сацумського порту Кагосіми; в 1864 р. i'єднаний підрозділ військово-морських сил Америки, Голландії й Англії .руйнував берегові фортифікації Чосю в районі Сімоносекі. John M. Maki. lapanese Militarism, pp. 146-147.

${ }^{28}$ Все це нагадує одну з тих реформ, що здійснювалися в Пруссії після 1810 року у відповідь на палкий заклик Блюхера до Берліна: "Дайте нам паціональну армію!" Vagst. A History of Militarism, p. 130; Cf. Gordon ^. Craig. The Politics ot the Prussian Army, ch. 2. 


\section{УЯВЛЕНІ СІІІЬНОТИ}

із половиною століть ізоляції та внутрішньої пацифікації з боку бакуфу. Хоча японська мова, якою говорили на о.Кюсю, залишалася здебільшого незрозумілою на о.Хонсю, іi навіть Едо-Токіо та Кіото-Осака мали проблеми з мовног) комунікацією, на островах уже здавна існувала напівкитајзована ідеографічна система для читання, а отже поширення масової письменності через школи й друк відбувалося легко й без проблем. По-друге, унікальна стародавність імперського дому (Японія є єдиною країною, де протягом усієї відомої нам історії монархія була монополізована лише однією династією), та її показова японськість (на відміну від Бурбоніз чи Габсбургів), полегшувала використання образу імператора в офіційно-націоналістичних цілях ${ }^{29}$. По-третє, варварське проникнення було несподіваним, масовим і достатньо загрозливим для того, щоб більшість прошарків політичносвідомого населення згуртувалися навколо програми самозахисту, складеної в новому національному дусі. Можливість ця, підкреслимо, була пов'язана з тим, що західне проникнення відбулося у 1860-х рр. , а не, скажімо, 1760-х роках. Адже на той час в більшій частині Свропи вже протягом півстоліття вступала в свої права "національна спільнота", як у демократичній, так і в офіційній версіях. Завдяки цьому самозахист можна було формувати за прикладом й у відповідності з тим, що все більш ставало "загальноприйнятою нормою".

Гра була варта свічок, попри жахливі страждання, перенесені селянством, на якого впав тягар немилосердних фінансових поборів, необхідних для покриття мілітаризованої індустріальної програми. Успіх, безперечно, було забезпечено у тому числі й цілеспрямованою рішучістю самих олігархів. Вони мали щастя прийти до влади тієї доби, коли номерні рахунки в Цюріху були справою надто далекого

${ }^{29}$ Проте японісти довели до мого відома, що нещодавні розкопки найдавніших королівських гробниць дають серйозні лідстави гадати, шо рід міг бути започаткований - який жах! - корейцями. Японський уряд рішуче перешкодив проведенню подальших досліджень цих могил. 
мійбутнього, тому ніщо їх не спокушувало розміщувати (iр)имані надлишки поза межами Японії. Отримавши нагоду щ)авити в ту пору, коли військова техніка прогресувала иідносно неквапливими темпами, завдяки програмі модерніиіції озброєнь вони спромоглися під кінець століття переІ ворити Японію в самостійну військову силу. Пропаговані " школах і пресі яскраві перемоги, здобуті японською регулирною армією над Китаєм в 1894-1895 рр., а її військовоморським флотом над Російською імперією в 1905 р., плюс :щексія Тайваню (1895) і Кореї (1910), виявилися надзвичайик) важливими для ствердження загального переконання в юму, що консервативна олігархія була істинним пред1."ґвиком нації, членами якої починали себе уявляти японці.

Те, що цей націоналізм набрав агресивного імперіалістичиюго характеру, навіть за межами правлячих кіл, найкраще мюжна пояснити двома факторами: спадком довгої ізоляції ялюоії й потужністю офіційно-національної моделі. Маруима проникливо зазначає, що всі націоналізми Європи вишикли в умовах традиційного плюралізму династичних ц:ржав - як я підкреслював раніше, європейський універ'алізм латини ніколи не мав політичного кореляту ${ }^{30}$ :

Національна свідомість в Свропі таким чином від самого початку несла печать свідомості міжнародного співтовариства. Здавалося самозрозумілим, що суперечки між суверенними державами були конфліктами між незалежними членами цього міжнародного співтовариства. Саме 3 цієї причини війна, починаючи від Гроція, займала незмінно важливе місце в міжнародному праві.

( )днак, сотні років японської ізоляції означали, що ${ }^{31}$ :

цілковито бракувало усвідомлення рівноправності в міжнародних справах. Прибічники вигнання [варварів] розглядали міжнародні відносини з позицій національної ієрархії,

\footnotetext{
${ }^{30}$ Maruyama Masao. Thought and Behaviour in Modern Japanese Politics, p. 138.

${ }^{31}$ Ibid., p. 139-140.
} 


\section{УЯВЛЕНІ СПІЛЬНОТИ}

заснованої на пануванні виших над нижчими. В результаті, коли засади національної ієрархії були горизонтально перенесені до міжнародної сфери, всі міжнародні проблеми звелися до єдиної альтернативи: завойовуй або будь завойованим. При відсутності будь-яких вищих нормативних стандартів для оцінки міжнародних відносин, правилом стає політика з позиції сили, а вчорашня несмілива оборонна доктрина стає нинішнім нестримним експансіонізмом.

По-друге, головним взірцем для олігархії стали самонатуралізовані європейські династії. Оскільки ці династії визначали себе дедалі більше й більше в національних категоріях, одночасно поширюючи свою владу поза межами $\Theta_{\text {вро- }}$ пи, немає нічого дивного в тому, що ця модель мала сприйматися в імперському трактуванні “. Як показав поділ Африки на берлінському конгресі (1885), великі нації були глобальними загарбниками. Наскільки спокусливою для Японії мала здаватися думка, що аби бути прийнятою в коло "великих", їй теж необхідно перетворити Тенно в Імператора розпочати заморські походи, хай навіть вона й запізно починала гру й мала багато надолужувати. Ніщо не дає так гостро відчути, яким чином це все осідало в свідомості читачів, як наступні формулювання радикал-націоналістичного ідеолога й революціонера Кіта Іккі (1884-1937) з його вельми впливового “Nihon Kaizo Hoan Taiko" [Плану перебудови Японіï], опублікованого 1924 року"

Як і класова боротьба всередині напії, що ведеться за перерозподіл несправедливих привілеїв, так і справедлива війна між націями має призвести до реформування сучасних несправедливих розбіжностей. Британська імперія є мільйонером, що володіє багатствами в цілому світі; а Росія - це великий землевласник, що захопив північну половину зем-

${ }^{32}$ На жаль, єдина тогочасна альтернатива офіційно-національним династичним державам - Австро-Угорщина - не була скільки-небудь присутньою на Далекому Сході.

${ }^{33}$ Переклад на англійську й цитата з: Richard Storry. The Double Patriots, p. 38. 


\section{ОФІЦІЙНИЙ НАЦІОНАЛІЗМ ТА ІМПЕРІАЛІЗМ}

ної кулі. Японія з ії розкиданою жменькою островів належить до пролетаріату й має право оголосити війну великим державам-монополістам. Західні соціалісти суперечать собі, визнаючи за місцевим пролетаріатом право на класову боротьбу й одночасно засуджуючи війну, яку веде міжнаціональний пролетаріат, як мілітаризм і агресію... Якщо робітничому класу дозволяється об'єднатися для кровопролитного повалення несправедливої влади, то й Японія повинна отримати беззастережне схвалення для вдосконалення своєї армії й флоту та для ведення війни, спрямованої на зміну несправедливих міжнародних кордонів. В ім'я раціональної соціальної демократії Японія вимагає володіння Австралією й Східним Сибіром.

Залишається тільки додати, що разом із розширенням імперії після 1900 року японізації а la Маколей стала свідомою політикою держави. До корейців, тайванців й маньчжурів у міжвоєнні роки, а після вибуху війни на Тихому океані ï до бірманців, індонезійців й філіппінців застосовувалася політика, практичним взірцем котрої була європейська модель. І так само, як у Британс̨ькій імперії, дорога до метроиолії залишалась абсолютно перекритою для японізованих корейців, тайванців або бірманців. Вони могли досконало юозмовляти й читати японською мовою, але їм ніколи не судилося б головувати в префектурах Хонсю чи хоча 6 отримати Іризначення за межами тих регіонів, з яких вони походили.

Розглянувши ці три різні зразки "офіційного націона"ізму”, важливо підкреслити, що держави без жодних серйозиих претензій на велич і потужність також могли свідомо иаслідувати таку модель, якщо правлячі класи чи провідні иерстви цих держав відчували, џо їм загрожує загальносвітове поширення національно-уявленої спільноти. Повчальним може виявитись порівняння двох таких держав Сіаму й Угорцини в межах Австро-Угорщини.

Чулалонгкорн, який був сучасником Мейдзі й правив досить довгий час (з 1868 по 1910 pр.), захищав своє королівство від західного експансіонізму цілком інакшими засо- 


\section{УЯВЛЕНІ СПІЛЬНОТИ}

бами, ніж його японський колега ${ }^{34}$. Затиснений між Британськими Бірмою й Малаєю та Французьким Індокитаєм, він, замість будування потужної військової машини, присвятив себе хитрій маніпуляторській дипломатії. (Міністерство війни було засноване лише 1894 року.) Подібно до Європи XVIII ст., його збройні сили були в основному строкатою мішаниною з в'єтнамських, кхмерських, лаоських, малайських і китайських найманців та підлеглих. Не докладав він також особливих зусиль для того, щоб проштовхувати офіційний націоналізм засобами модернізованої освітньої системи. Справді, початкова освіта стала обов'язковою лише через більш ніж десять років після його смерті, а перший у країні університет було засновано лише 1917 року, через чотири десятиріччя після заснування токійського Імперського університету. Тим не менше, Чулалонгкорн вважав себе реформатором. Взірцями для нього служили проте не моделі Сполученого Королівства чи Німеччини, а радше колоніальні beamtenstaaten голландської Східної Індії, британської Малаї та Раджу [британської Індії] ${ }^{\text {sз }}$. Наслідування цих моделей означало раціоналізацію й централізацію королівської форми правління, ліквідацію традиційних напівавтономних дрібних держав-данників і сприяння економічному розвитку на дещо колоніальних засадах. Найразючішим прикладом цього - прикладом, який дивним чином нагадує нам сучасну Саудівську Аравію - стало заохочення ним масової імміграції молодих, самотніх іноземців-чоловіків для формування дезорієнтованої, політично слабкої робочої сили, необхідної для спорудження портового устаткування, прокладання залізничних колій, риття каналів і розширення

${ }^{34}$ Наступний блок є скороченою версією частини моїх "Студій з таїландської держави: Стан таїландських досліджень” з: Eliezег B. Ayal (ed.). The State of Thai Studies.

${ }^{35}$ Батті чудово демонструє, що метою візитів молодого монарха до Батавії й Сінгапуру 1870, а до Індії 1872 року були намагання, за власними обережними словами Чулалонгкорна, “обрати найбезпечніші моделі". Див.: Battye. The Military, Government and Society in Siam, 1868-1910, p. 118. 


\section{ОФІЩІЙНИЙ НАЦІОНАЛІЗМ ТА ІМПЕРІАЛІІЗМ}

комерційного сільського господарства. Це імпортування gaslurbeiter-ів співвідносилось і, фактично, наслідувало поліІпчний курс урядів Батавії й Сінгапуру. I подібно, як у вишадку з голландською Індією й Британською Малайсю,

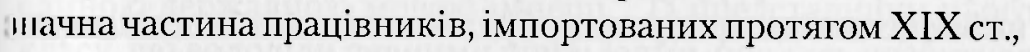
и)ходила з Південно-Східного Китаю. Показово, по цей курс ıе наражав його ні на докори сумління, ні на політичні ускладнення - так само, як і колоніальних правителів, з яких він брав ириклад. Більше того, подібна політика якийсь час навіть мала r'пс з точки зору династичної держави, створюючи слабкий ж)бітничий клас “поза" таїландським суспільством ізалишаючи щс суспільство здебільшого "непотривоженим".

Вачіравут, його син і наступник (правив з 1910 по 1925 рр.), продовжив справу, взявши цього разу за взірець "натуралізонаних" європейських монархів. Хоча він навчався у вікторіпиській Англії (а може, саме через це), він взяв собі роль "шершого націоналіста" своєї країни ${ }^{36}$. Вістря його націонапізму було, однак, спрямоване не проти Сполученого Королівства, що контролювало 90 відсотків торгівлі Сіаму, й не шроти Франції, яка лише нещодавно пішла зі східних теригорій старого королівства: його об'єктом стали китайці, котןих ще недавно так безпечно імпортував його батько. Стушінь антикитайської позиції може бути продемонстрована

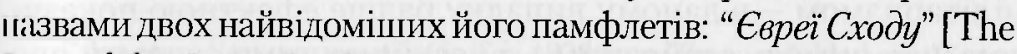
Jews of the Orient] (1914) i "Пута на наших колесах" (1915).

Звідки така зміна? Безперечно, свій вплив справили цраматичні події, що відбулися безпосередньо перед і після iюго коронації в листопаді 1910 року. Спочатку в червні цього року виявилось необхідним викликати поліцію для щрипинення в Бангкоці загального страйку китайських

\footnotetext{
36 "Натхненником націоналістичної програми Ваджіравуда [Вачіраву1:1] була перш за все Великобританія, західна нація, яку Ваджіравуд знав пайкраше і яка в цей час переповнювалась імперіалістичним ентузіазмом". Walter F. Vella. Chaiyo! King Vajiravudh and the Development of Thai Nationalism, p. XIV. Див. також стор. 6 і 67-68.
} 
торговців (дітей перших іммігрантів, які активно пробивалися вгору) і робітників, що ознаменувало їхнє залучення до сіамської політики ${ }^{37}$. Наступного року в Пекіні, зусиллями різнорідних угрупувань, серед яких, звичайно ж, не останнє місце посідали торговці, була зметена Небесна імперія. Таким чином, “китайці” поставали передвісниками народного республіканізму, який серйозно загрожував династичному принципу. По-друге, судячи зі слів, вжитих у назві памфлету - "Євреї“ та "Орієнт",- англізований монарх увібрав у себе специфічний расизм англійського правлячого класу. Але, крім цього, Вачіравут був таким собі азіатським Бурбоном. В донаціональну добу його предки залюбки брали собі за жінок і наложниць привабливих китайських дівчат, в результаті чого він сам, мовою Менделя, мав більше китайської, ніж таїландської “крові" .

Це $є$ добрим прикладом характерної особливості офіційного націоналізму - очікувальної стратегії, взятої на озброєння панівними колами, яким національно-уявлена спільнота загрожувала маргіналізацією або усуненням. (Само собою зрозуміло, що Вачіравут також почав маніпулювати всіма політичними важелями офіційного націоналізму: контрольованою державою обов'язковою початковою освітою, державною пропагандою, офіційним переписуванням історії, мілітаризмом - в даному випадку радше ефектною показухою, ніж чимось серйозним - і нескінченними заявами про тотожність династії й нації)

${ }^{37}$ Страйк був спричинений рішенням уряду стягувати з китайців такий самий подушний податок, що й з корінних таїландців. Раніше він був нижчий, як стимул до імміграції. Див.: Bevars D., Mabry. The Development of Labor Institutions in Thailand, p. 38. (Китайців переважно використовували на опіумних фермах.)

${ }^{38}$ Докладніше шодо генеалогії див. мої "Studies of the Thai State”, p. 214

${ }^{39}$ Він також склав гасло “Chat, Sasana, Kasat” (Нація, Релігія, Монарх), яке стало паролем правих режимів Сіаму останньої чверті століття. Тут “Самодержавство, Православ'я, Народність” Уварова постають у зворотній таїландській послідовності. 


\section{ОФІЦІЙНИЙ НАЦІОНАЛІЗМ ТА ІМПЕРІАЛІЗМ}

Розвиток угорського націоналізму ХІХ ст. демонструє шший варіант "офіційної” моделі. Ми вже згадували раніше щро несамовитий опір латиномовної мадярської аристократії памаганням Йосифа II в 1780-х роках зробити німецьку 1 диною державною мовою імперії. Ті представники цього к./асу, що володіли певними привілеями, боялись позбутися своїх синекур у централізованому, чітко організованому у (яді, опанованому імперсько-німецькими бюрократами. I Іижчі ж ешелони були нажахані можливістю втратити право Іа звільнення від податів і обов'язкової військової служби, il 'акож свій контроль над кріпаками й сільською адміністрацією. Однак, поруч із захистом латини, з'являлися, цілком ' 'лушно, й висловлювання на користь мадярської мови, "адже ") кінцевому підсумку мадярський уряд видавався єдиною рсальною альтернативою німецькому" ${ }^{40}$. Бела Грюнвальд ("аркастично зауважив, що "ті самі повіти, котрі (виступаючи ироти імператорського указу) наголошували на можливості "гворення мадяромовного уряду, 1811 року - тобто через цзадцять сім років - заявили, що це зробити неможливо". ІІе через два десятиріччя, в одному з вельми "націоналісгичних" угорських повітів було проголошено, що "запровацження мадярської мови поставить під загрозу нашу конституцію і всі наші інтереси" . По-справжньому лише в

${ }^{40}$ Ignotus. Hungary, pp. 47-48. Так 1820 року Tiger im Schlafrock (Тигр у пічній сорочці), імператор Франц II, справив гарне враження своїм . птиномовним зверненням до угорських магнатів, зібраних у Пешті. Проте вже 1825 року радикальний романтик, великий землевласник, граф lıтван Сечені “приголомшив своїх колег-магнатів”, звернувшися до них у ('еймі на мадярській мові! Jaszi. The Dissolution, p. 80; and Ignotus. Hungary, p. 51.

Переклад на англійську цитати з “The Old Hungary” (1910) in Jaszi. The Dissolution, pp. 70-71. Грюнвальд (1839-1891) був цікавою й трагічною ностаттю. Народившись у мадяризованій шляхетній родині саксонського Іоходження, він став не лише чудовим управителем, але й одним із перших 13 Угорщині суспільствознавців. Публікація його дослідження, в якому зиамениті, контрольовані мадярською шляхтою "повіти" викривались у икості паразитів напії, спровокувала нестямну кампанію громадського паплюження. Він втік до Парижа, де й утопився в Сені. Ignotus. Hungary, pp. 108-109. 


\section{УЯВЛЕНІ СПІЛЬНОТИ}

1840-х роках мадярська аристократія - клас, що складався приблизно з 136,000 осіб, котрі монополізували землю й політичні права в країні з населенням у одинадцять мільйонів $^{42}$ - стала серйозно підтримувати мадяризацію, та й то лише для запобігання власній історичній маргіналізації.

Водночас поступове зростання рівня письменності (третина дорослого населення в 1869 р.), поширення друкованої мадярської мови й поява малочисельної, але активної ліберальної інтелігенції - все це сприяло посиленню демократичного угорського націоналізму, побудованого на цілком відмінних від аристократичного варіанту засадах. Цей демократичний націоналізм, символом якого для майбутніх поколінь стала постать Лайоша Кошута (1802-1894), тріумфував під час революції 1848 року. Революційний режим не тільки позбувся імперських управителів, призначених Віднем, але й розпустив начебто промадярський феодальний Сейм повітової шляхти й проголосив реформи, направлені на скасування кріпацтва й неоподаткованого статусу дворянства, а також на рішуче обмеження спадкових прав на маєтки. Крім того, було вирішено, що всі, хто розмовляють угорською, повині бути угорцями (якими раніше вважалася тільки знать), а кожен угорець повинен володіти мадярською мовою (яку досі звикли вживали тільки декотрі мадяри). Як іронічно зауважив Ігнотус, “за стандартами того часу (що 3 безмежним оптимізмом спостерігав за сходженням двох зірок-близнюків - лібералізму й націоналізму) «нація» цілком виправдано почувала себе надзвичайно щедрою, коли «приймала» мадярських селян без жодної дискримінації, крім майнової ${ }^{43}$; християн немадярського походження з умовою, що ті стануть мадярами; і зрештою, досить неохоче і з затримкою в двадцять років - євреїв" ${ }^{\prime \prime}$. Сам Кошут, у своїх

\footnotetext{
${ }^{42}$ Jaszi. The Dissolution, p. 299.

${ }^{43}$ Режим Кошута запровадив право голосу для повнолітніх чоловіків проте з таким високим майновим цензом, шо відносно мало осіб були спроможні брати участь у голосуванні.

${ }^{44}$ Ignotus. Hungary, p. 56.
} 
безплідних переговорах з лідерами різних немадярських меншин, стояв на тій позиції, що ці народності повинні мати однакові з мадярами громадянські права, але, враховуючи брак “історичної фізіономії", вони не можуть формувати власні нації. Нині ця позиція може видаватися дещо зарозумілою. Проте вона виглядатиме цілком невинно, якщо пригадати, як блискучий молодий радикал-націоналістичний поет Шандор Петефі (1823-1849), провідна постать 1848 року, якось назвав меншини “виразками на тілі вітчизни",

Після придушення революційного режиму царськими військами в серпні 1849 року Кошут опинився у пожиттєвому вигнанні. Сцена була тепер готова для відродження "офіційного" мадярського націоналізму, взірцем якого стали реакційні режими графа Кальмана Тіси (1875-1890) та його сина Іштвана (1903-1906). Красномовними є причини цього відродження. Впродовж 1850-х років авторитарно-бюрократичний уряд Баха у Відні посднував жорсткий політичний утиск із рішучим здійсненням принаймні частини соціальнополітичного курсу, проголошеного революціонерами 1848 року (перш за все скасування кріпацтва й неоподаткованого статусу дворянства), і створенням умов для розвитку модернізованих комунікацій і великомасштабного капіталістичного підприємництва ${ }^{46}$. Здебільшого позбавлені своїх феодальних привілеїв і забезпечень та неспроможні економічно конкурувати з великими латифундистами й активними німецькими та єврейськими підприємцями, представники середнього й нижчого прошарку мадярської аристократії занепадали, перетворюючись у сердиту й зацьковану дрібну сільську шляхту.

Фортуна, однак, була на їхньому боці. Зазнавши 1866 року ганебної поразки від прусських військ під Кенігграцом, Відень був примушений погодитись на встановлення дуаліс-

\footnotetext{
${ }^{45}$ Ibid., p. 59.

${ }^{46}$ Ігнотус зауважує, по Бах таки забезпечив дворянство певними фігансовими компенсаціями за втрату своїх привілеїв, "мабуть, не більшими й не меншими від тих, що їм міг би надати й Копут" (стор. 64-65).
} 


\section{УяВЛЕНІ СІІЛЬНОТИ}

тичної монархії згідно з Ausgleich (компромісом) 1867 року. Відтоді Угорське королівство мало дуже велику автономію в усьому, що стосувалося його внутрішніх справ. Першими, хто отримав користь від Ausgleich, стала група найвищих мадярських аристократів і освічених професіоналів ліберального спрямування. В 1868 р. адміністрація просвіщеного магната графа Дьюли Андраші прийняла Закон про національності, який надавав немадярським меншинам "всі права, на які вони претендували чи могли претендувати - крім перетворення Угорщини в федерацію" ку Тісою посади прем'єр-міністра започаткувало добу, коли реакційна пляхта успішно повернула втрачені позиції, відносно незалежні від втручання з боку Відня.

В галузі економіки режим Тіси розв'язав руки великим аграрним магнатам ${ }^{48}$, але політична влада була значною мірою монополізована дрібним дворянством. Адже,

для позбавлених власності залишався один притулок: адміністративна мережа національного й місцевого уряду та армія. Для цього Угорщині необхідно було мати величезний штат службовців; принаймні, вдавати, що йй це необхідно. Півкраїни складалося з "національностей", які треба було контролювати. Утримання сили-силенної надійних, мадярських, благородного походження державних службовців для цього контролю вважалося поміркованою ціною для національної справи. Національна проблема була просто знахідкою; вона виправдовувала існування численних синекур.

Таким чином, "магнати отримали спадкові маєтки; дворянство отримало спадкові посади”" . Такими були соціальні засади немилосердної політики примусової мадяризації, що

${ }^{47}$ Ibid., p. 74.

${ }^{48}$ В результаті між 1867 і 1918 рр. утричі зросла кількість спадкових маєтків. Якщо сюди додати церковне майно, то ціла третина всієї землі в Угоршині стала заповідною наприкінці існування подвійної монархії. Німецьким і єврейським капіталістам також добре велося під час режиму Ticu.

${ }^{49}$ Ibid., pp. 81 and 82. 


\section{ОФІЦІЙНИЙ НАЦІОНАЛІЗМ ТА ІМПЕРІАЛІЗМ}

після 1875 року перетворила Закон про національності на жмуток паперу. Легальне звуження виборчого права, розмноження фіктивних округів, шахрайські вибори й організований політичний бандитизм у сільській місцевості ${ }^{5 .}$ одночасно зміцнювали владу Тіси та його виборців і підкреслювали “офіційний” характер їхнього націоналізму.

Йазі цілком слушно прирівнює цю мадяризацію кінця XIX ст. до "політики царської Росії щодо поляків, фінів і русинів; політики Пруссії щодо поляків і датчан; і політики феодальної Англії щодо ірландців"э. . Зв'язок між реакціошерством і офіційним націоналізмом чудово ілюструється гакими фактами: тоді як мовна мадяризація була центральпим елементом політики режиму, наприкінці 1880-х рр. лише $2 \%$ чиновників у найважливіших службах центрального й місцевих урядів були румунами, хоча румуни становили $20 \%$ населення, i “навіть ці 2 \% служать у найнижчих чинах". 3 іншого боку, напередодні Першої світової війни в угорському парламенті не було “жодного представника робітничого класу й безземельного селянства (тобто абсолютної більшості населення країни)... а з 413 членів парламенту палічувалося тільки 8 румунів і словаків, і це в країні, де лише $54 \%$ мешканців розмовляли мадярською мовою, як своєю рідною" ${ }^{\text {33 }}$ Не дивно отже, шо коли Відень направив 1906 ро-

${ }^{s 0}$ Бандитизмом в основному займалися сумнозвісні "пандури", армійські підрозділи, передані в розпорядження повітових адміністрацій і задіяні в ролі жорстокої сільської поліцііі.

${ }^{51}$ The Dissolution, p. 328.

52 Згідно з підрахунками Лайоша Мочарі ( Some Words on the Nationality Problem, Budapest, 1886), зацитованими в: ibid., pp. 331-332, Мочарі (1826-1916) заснував 1874 року в угорському Парламенті невеличку партію Незалежності для боротьби за ідеї Кошута, особливо з проблеми меншин. Його промови, що викривали кричуші порушення з боку Тіси Закону про Національності 1868 року, призвели спочатку до того, шо його фізично виштовхали з парламенту, а потім і виключили з лав власної партії. 1888 року він повернувся до парламенту через цілком румунський виборчий округ і перетворився практично на політичного парію. Ignotus. Hungary, p. 109.

${ }^{53}$ Jászi. The Dissolution, p. 334. 
ку війська для розпуску парламенту, “на протест проти нової доби «віденського абсолютизму»" не зібрався жодний мітінг, не було вивішено жодного плакату чи видано жодної відозви до народу. Навпаки, робітничі маси й національні меншини зловтішно спостерігали за безсилими потугами національної олігархії"

Тріумф після 1875 року “офіційного націоналізму” реакційної мадярської шляхти не можна, однак, пояснити лише політичною силою цього прошарку або свободою маневру, успадкованою від Ausgleich. Фактом залишається те, що до самого 1906 року Габсбурзький двір не відчував потреби рішуче обстоювати свої права супроти режиму, який у багатьох відношеннях залишався опорою імперії. Перш за все, династія була неспроможна запропонувати вироблений власними зусиллями офіційний націоналізм. Не просто тому, шо цей режим був, за словами видатного соціаліста Віктора Адлера, "Absolutismus gemildert durch Schlamperei [абсолютизмом, пом'якшеним недбалістю]”. Довше ніж будь-де,

${ }^{\circ 4}$ Ibid., p. 362. Ця "національна олігархія" перенесла навіть у двадияте століття властивий ій фальш. Йазі переказує цікаву розповідь одного 3 кореспондентів відомої угорської газети, який під час Першої світової війни брав інтерв'ю в пораненого офіцера, котрий згодом, у міжвоєнні роки, стане реакційним диктатором У горщини. Хорті розлютило те, шо в статті було описано, як його думки "линуть до угорської батьківщини, землі його предків”. "Запам'ятайте, - сказав він, - якшо мій головнокомандуючий $є$ в Бадені, то там і моя батьківшина!" The Dissolution, p. 142.

Ibid., p. 165. "А в старі добрі часи, коли ше існувала імперська Австрія, можна було облишити поїзд часу, сісти до звичайного поїзда звичайної залізниці й вирушити додому... Зрозуміло, що тими шляхами вже їздили й автомобілі - але ще не надто часто! Завоювання повітряного простору також вже почалося, але не надто інтенсивно. Подеколи до Південної Америки чи Далекого Сходу виряджався корабель; але не надто часто. Тут не прагнули здобувати світові ринки й ставати світовою державою. Ви перебували тут у центрі Європи, у перехрещенні старих світових вісей; слова «колонія« й «заморський» мали в собі відгомін чогось іще цілком невідчутого й далекого. Тут можна було наштовхнутися на демонстрування розкоші, проте, звісно, не надміру вишуканої, наче у Франції. Можна було захоплюватися спортом; але не в шаленому англо-саксонському стилі. Можна було витрачати величезні суми на армію; але лише для 


\section{ОФІЦІЙНИЙ НАЦІОНАЛІЗМ ТА ІМІЕЕРІАЛІЗМ}

династія залишалася вірною застарілим концепціям. "У своємуреліzійному містицизмі кожен із Габсбургів відчував себе особливим чином пов'язаним із небесами, як виконавець божественної волі. Цим пояснюється їхня майже безпринципна позиція серед виру історичних катастроф та їхня загальновідома невдячність. Der Dank vom Hause Habsburg увійшло у прислів'я" ${ }^{56}$. До того ж, нестерпні ревнощі до Пруссії Гогенцоллернів, що все більше вдягалася в обладунок Священної Римської імперії та перетворювала себе в Німеччину, примушували династію наполягати на гордовитому “патріотизмі для мене самого" Франца II.

Водночас цікаво, що наприкінці свого існування династія, мабуть, і сама цього не очікуючи, виявила певну споріднеиість із соціал-демократами, причому до тієї міри, що дехто 3 їх спільних ворогів глузливо називали це "Burgsozialismus [придворним соціалізмом]”. Ця тимчасова коаліція безумовно спиралася на суміш макіявеллізму й ідеалізму з обох боків. Свідчить про те палка кампанія, яку австрійські соціаллемократи розгорнули проти економічного й військового “сепаратизму”, нав'язуваного в 1905 році режимом графа Іштвана Тіси. Карл Реннер, скажімо, "картав малодушність австрійської буржуазії, котра починала мовчки погоджуватись із сепаратистськими планами мадярів, хоч «угорський ринок незрівняно важлівішшй для австрійського капіталу, піж марокканський для пімецького», за який так активно бореться німецька зовнішня політика. У вимогах незалежної угорської митної зони він не бачив нічого, крім наступу міських здирників, шахраїв і політичних демагогів на безпосередні інтереси австрійської промисловості, австрійського

того, шоб впевнено залишатися серед світових держав другою найслаб๓юю". Robert Musil. The Man Without Qualities, I, pp. 31-32. Це один із иайкомічніших романів двадцятого століття.

Jászi. The Dissolution, p. 135. Виділено автором. Коли після заворушень 1848 року Меттерніх був змушений піти у відставку й рятуватися штечею, "ніхто при дворі не поцікавився, куди він вирушить і як житиме". Sic transit. 
робітничого класу й угорських хліборобів ${ }^{57}$. Подібним чином, Отто Бауер писав, що :

В добу російської революції [1905 року] ніхто не наважиться вживати грубу військову силу для підкорення країни [Угоршини], яку розривають класові й національні протиріччя. Але внутрішні конфлікти країни забезпечать престол іншим знаряддям влади, який він буде змушений використовувати, якщо не бажає розділити долю династії Бернадоттів. Він не може виражати дві волі, намірюючись і далі правити Угоршиною й Австрією. Отже, він мусить забез-

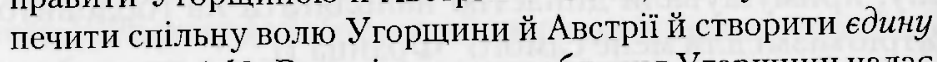
державу [Reich]. Внутрішнє роздроблення Угоршини надає престолу можливість досягти цієї мети. Він спорядить свою армію до Угорщини, щоб знову завоювати їі для монархії, але на свої знаменах він напише: Непідкупне, загальне й рівне виборче право! Право на об'єднання для сільськогосподарських робітників! Національна автономія! Він протиставить ідеї самостійної угорської національної держави [Nationalstaat] ідею Cполучених IIIтатів Великої Австрії [sic], ідею федеративної держави [Bundesstaat], в якій кожна нація незалежно вестиме власні національні справи, а всі нації об'єднаються в одній державі для захисту спільних інтересів. Неминуче й невідворотньо ідея федеративної держави національностей [Nationalitätenbundesstaat] стане знаряддям Корони [sic! - Werkzeug der Krone], чиє королівство руйнується через занепад дуалізму.

У цих Сполучених Штатах Великої Австрії (СШВА), здається, не важко помітити поєднання елементів США та Сполученого Королівства Великобританії й Північної Ірландії (яким колись керуватиме лейбористська партія), а також i передвістя Союзу Радянських Соціалістичних Республік, територія якого на диво точно співпадає 3 володіннями цар-

57 Ibid., p. 181. Виділено нами.

58 Otto Bauer. Die Nationalitätenfrage und die Sozialdemocratie (1907), : його Werkausgabe, I, p. 482. Курсив у оригіналі. Порівняння цього перекладу з інтерпретацією Йазі, що містилася в оригінальній версії цієї книги дає поживу для роздумів. 


\section{ОФІЦІЙНИЙ НАЦІОНАЛІЗМ ТА ІМІІЕ' ІАЛІІЗМ}

ської імперії. Фактом залишається те, що ці СШВА, в голові того, хто їх уявляв, видавалися очевидним спадкоємцем певної династичної вотчини (Великої Австрії) - і навіть обдаровані виборчим правом складові частини були ті самі, що іх протягом сторіч "нагендлювали” Габсбурги.

Подібного роду "імперіалістичні” уявлення були частиною нещасть соціалізму, народженого в столиці однієї з великих європейських династичних імперій ${ }^{\circ}$. Як ми зазначали раніше, нові уявлені спільноти (включаючи мертвонаро„жені, як СШВА), витворені за допомогою лексикографії й капіталістичного друкарства, завжди вважали себе старовинними. В добу, коли "історія" ще сприймалася в образі “великих подій" i "великих лідерів", подібно до перлин, нанизаних иа нитку сюжету, здавалося спокусливим читати історію давніх династій як колективне минуле народу. Звідси й СШВА, в яких грань, що відділяє імперію від нації, престол від пролетаріату, майже непомітна. До того ж, Бауер не був тут надто оригінальним. Вільгельм Завойовник і Георг I, жодний з яких не розмовляв англійською, продовжують без будь-яких проблем виблискувати окремими самоцвітами в кольє під назвою "Королі Англії. "Святий” Стефан (правив i 1001 по 1038 рр.) міг нагадувати своєму наступникові, що ${ }^{60}$ :

Користь від іноземців і гостей така велика, що вони повинні займати одне з найпочесніших місць серед усіх королівських оздоб... Адже, прибуваючи з різних країн і провінцій, вони приносять із собою різні мови й звичаї, всілякі знання і предмети зброї. Все це прикрапає королівський двір, збільшує його велич і відлякує чванливих чужоземних володарів. Бо країна, де мова й звичаї є однаковими, лишається недовговічною й слабкою...

${ }^{59}$ Вони також, безперечно, віддзеркалюють специфічний склад мислення добре відомого типу європейського інтелектуала лівого крила, що Іишався своїм знанням цивілізованих мов, спадщиною Просвітництва й проникливим розумінням будь-чиїх проблем. Ця пиха складалася із до'ить рівномірно змішаних інгредієнтів інтернаціоналізму й аристократизму.

Jaszi. The Dissolution, p. 39. 


\section{УЯВЛЕНІ СПІЛЬНОТИ}

Проте ці слова жодною мірою не завадили його пізнішому прославлюванню як Першого Короля Угорщини.

Підбиваючи підсумки, зазначимо, що приблизно з середини XIX ст. в Європі виникли, за термінологією Сетон-Вотсона, "офіційні націоналізми". Ці націоналізми були історично "неможливими" аж до появи демократичних мовних націоналізмів, адже, по суті, вони стали відповіддю владних угрупувань - в основному, хоч і не винятково, династичних i аристократичних - на загрозу маргіналізації або повного усунення з нових уявлених спільнот народу. Починалося тектонічне зрушення, яке, після 1918 і 1945 рр., пожбурило ці угрупування в каналізаційні люки Есторілу й МонтеКарло. Хоча й консервативні, коли не реакційні, ці офіційні націоналізми були формою політики, запозиченої із попередніх, переважно стихійних народних націоналістичних pухів $^{61}$. Не обмежувалися вони, зрештою, Європою та Левантом. Подібну політику в ім'я імперіалізму вели аналогічні групи на багатьох азіатських і африканських теренах, підкорених протягом XIX ст. ${ }^{62}$ Нарешті, своєрідно віддзеркалені

61 Півсторіччя тому Йазі вже це припускав: “Виникає питання, чи нешодавня імперіалістична еволюція націоналізму бере свій початок зі справжніх джерел національної ідеї, а не породжена монополістичними інтересами певних груп, які $є$ цілком чужими оригінальній концепції національних задумів". Ibid., p. 286. Виділено нами.

${ }_{62}$ Ця думка отримає своє підтвердження, так би мовити, від протилежного у прикладі з Голландською Індією, в якій до самого кінця правління відбувалося великою мірою на мові, що нині нам відома як “індонезійська". Це, я гадаю, $\epsilon$ винятковим зразком великого колоніального володіння, в якому неєвропейська мова залишалась до кінця державною мовою. Цю аномалію можна пояснити перш за все звичайною стародавністю колонії, яка була заснована на початку сімнадцятого сторіччя однією корпорацією (Vereenigde Oostindische Compagnie) задовго до епохи офіційного націоналізму. Свою роль, безсумнівно, зіграв і брак упевненості з боку голландців, шо в сучасні часи їня мова й культура мають достатній європейський престиж порівняно з англійською французькою, німецькою, іспанською чи італійською. (Бельгійці в Конго радше вживали французьку, ніж фламандську мову ). Зрештою, над- 


\section{ОФІЦЙНИЙ НАЦІОНАЛІЗМ ТА ІМІІЕРІАЛІЗМ}

неєвропейськими культурами та історіями, вони виявилися Ітридатними для імітації місцевими правлячими групами тих нечисленних територій (серед яких були Японія й Сіам), що уникли прямого підкорення.

Майже в кожному випадку офіційний націоналізм приховував невідповідність між нацією й династичною державою. Звідси й загальносвітове протиріччя: словаки мадяризувались, індійці англізувались, а корейці японізувались, та їм не дозволялось приєднуватись до паломництв, які б давали можливість керувати мадярами, англійцями чи японцями. Бенкет, на який їх запрошували, завжди виявлявся учтою Бармесида. Причиною того був не просто расизм; велику роль відігравав той факт, що в самому осерді імперій також народжувалися нації - угорська, англійська й японська. I ці нації також інстинктивно чинили опір “чужому” правлінню. Імперіалістична ідеологія другої половини XIX ст. мала в собі, таким чином, щось від типових трюків фокусника. Наскільки все це було трюком, свідчить незворушність, 3 якою народні маси метрополій поставились до “втрат" колоній, навіть у випадках, подібних до Алжиру, де колонія була легально приєднана до метрополії. Врешті-решт, саме правлячі класи, буржуазні, а перш за все аристократичні, завжди гривалий час оплакують імперії, а їхній сум є завжди надто театральним.

звичайно консервативною була колоніальна освітня політика: 1940 року, коли корінне населення налічувало вже понад 70 мільйонів, тільки 637 "тубільців" навчалися у коледжі, й лише 37 отримали ступінь бакалавра. Див.: George McT. Kahin. Nationalism and Revolution in Indonesia, p. 32. Більше на тему Індонезіі буде далі, у VII розділі. 


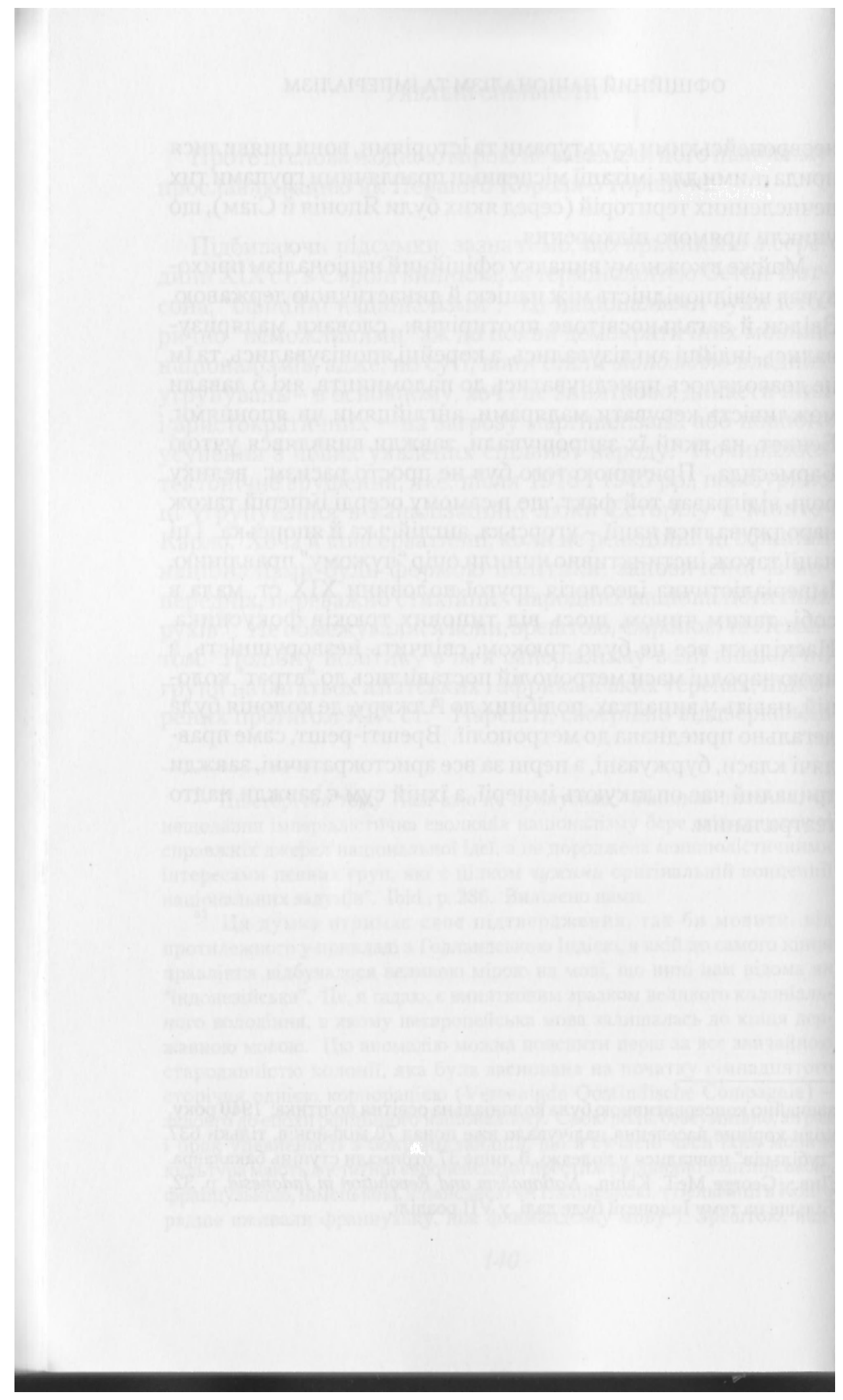




\section{Остання хвиля}

Перша світова війна покінчила з епохою великих династій. У 1922 р. вже не залишилось ні Габсбургів, ні Гогенцоллернів, ні Романових, ані Османів. На місці Берлінського Конгресу з'явилася Ліга Наиій, відкрита і для неєвропейських народів. Відтепер легітимною міжнародною нормою стала національна держава, тому навіть уцілілі імперії прибули до Ліги в національному платті, а не в імперській уніформі. Після катаклізму Другої світової війни ріка національної державності стала широкою й повноводною. В серелині 1970-х років навіть від Португальської імперії не лишилося й сліду.

Нові держави, що виникли після Другої світової війни, мали свої особливості, які, однак, неможливо було б зрозуміти без урахування спадкового впливу розглянутих нами моделей. Достатньо пригадати, що для досить значної кількості цих (в основному неєвропейських) націй саме європейські мови стали державними. Якшо в цьому відношенні вони нагадували "американську" модель, то від мовних європтейських націоналізмів вони успадкували ревний популізм, а від офіційного націоналізму - орієнтацію на русифікаторську політику. Вони вчинили так, тому що американці з європейцями накопичили великий історичний досвід, який 


\section{УяВЛЕНІ СІІЛЬНОТИ}

повсюдно тепер здавався зразком, й тому що європейські державні мови, залучені ними, були спадщиною імперіалістичного офіційного націоналізму. Ось чому так часто в політичному курсі нових держав на "національне будівництво" можна віднайти сліди як щирого й масового національного ентузіазму, так і систематичного, навіть мак'явеллівського, прищеплювання націоналістичної ідеології через засоби масової інформації, освітню систему, урядові постанови тощо. В свою чергу, ця суміш народного й офіційного націоналізмів сама була продуктом аномалій, створених європейським імперіалізмом: відомої довільності кордонів та існування двомовної інтелігенції, що хитко височіла над різними одномовними народностями. Таким чином, значну частину цих націй можна розглядати як ще нездійсненні проекти, причому проекти, задумані швидше в дусі Мадзіні, ніж Уварова.

Розмірковуючи над походженням новітнього “колоніального націоналізму”, відразу помічасш його основну подібність із колоніальними націоналізмами минулої доби: ізоморфізм між територіальним поширенням кожного 3 націоналізмів і територіями попередніх імперських адміністративних одиниць. Ця подібність зовсім не випадкова; вона пов'язана із географією колоніальних паломництв. Різниця ж полягає в тому, що обриси креольських паломництв XVIII ст. окреслились внаслідок не тільки централізаторських амбіцій абсолютизму метрополій, але й внаслідок реальних проблем комунікації й пересування, а також загальної технологічної примітивності. В ХХ ст. всі ці проблеми були в цілому вирішені, а на їх зміну прийшла дволика "русифікація".

Я вже пробував показати, що наприкінці XVIII ст. імперські адміністративні одиниці почали набувати національного значення частково тому, що обмежували просування креольських функціонерів. Те саме і в XX ст. Адже навіть у тих випадках, коли молодий жовто- або чорношкірий англієць прибував до метрополії з метою отримати певну освіту чи підготовку, на що могли спромогтися небагато 3 йоги креольських предків, це, як правило, було останнім його 
бюрократичним паломництвом. Відтепер вершиною його кар'єри ставав найвищий адміністративний центр, до якого він міг отримати призначення: Рангун, Аккра, Джорджтаун чи Коломбо. Але під час кожної з таких подорожей він зустрічав двомовних колег-мандрівників, 3 якими відчував усе більпу спільність. Протягом своєї подорожі він швидко починав розуміти, що місце його походження - в етнічному, мовному чи географічному розумінні - не має великого зна'ення. Воно було лише початком цього, а не іншого паломництва, але не визначало суттєво ні кінцевого пункту подорожі, ні попутників. Ця схема привела до непомітної, напівирихованої, поступової трансформації колоніальної держави в національну, трансформації, яка стала можливою не тільки завдяки тяглості кадрів, але й завдяки усталеній мережі подорожей, під час яких приходило усвідомлення кожної 3 ıих держав її функціонерами! .

Проте, починаючи від середини XIX ст. й особливо в столітті XX, в подібні подорожі вже вирушала не жменька мандрівників, а величезні й строкаті юрми. На це вплинули три глловні фактори. Перш за все, неймовірне зростання фізичної мобільності завдяки дивовижним досягненням промислового капіталізму - залізницям і пароплавам у минулому 'толітті, автотранспорту й авіації в цьому. Нескінченні мандри територіями старого американського континенту швидко відходили в минуле.

По-друге, імперська "русифікація" мала не тільки ідеологінний, але й практичний бік. Вже один тільки розмір глобальних європейських імперій і численність підлеглих народностей означали, що чисто метропольну чи навіть кре-

${ }^{1}$ Звичайно, не тільки функціонерами, хоча вони й становили основну ґрупу. Згадаймо, скажімо, географію роману "Noli Me Tangere" (як і hillaтьох інших націоналістичних романів). Хоч дехто з головних героїв юксту Рісаля $є$ іспанцями, а деякі дійові особи-філіппінці бували колись "I Іпанії (поза романним простором), середовище, в якому подорожує (ууць-хто з героїв, обмежується тим регіоном, який, через одинадцять років иісля публікації твору й через два роки після страти автора, мав стати Џіліппінською республікою. 
ольську бюрократію було неможливо ані набрати, ані забезпечити. Колоніальна держава, а дещо згодом корпоративний капітал, потребували цілих армій чиновників, які, щоб приносити користь, мали бути двомовними, здатними виконувати роль лінгвістичних посередників між метропольною нацією й колонізованими народами. Потреба в цьому тільки зросла, коли з початком нового століття повсюдно функції держави множилися й спеціалізувалися. Поруч із старим дільничим з'явилися начальник медслужби, інженер з іригації, сільськогосподарський консультант, шкільний учитель, поліцейський тощо. 3 кожним розширенням держави зростала й юрба його внутрішніх пілігримів .

Третім фактором було поширення сучасної освіти, не тільки колоніальною державою, але й також приватними релігійними й світськими організаціями. Це відбувалося не просто для забезпечення кадрами урядових і корпоративних ієрархій, але й тому, що зростало усвідомлення моральної цінності сучасних знань навіть для колонізованих народів ${ }^{3}$. (Фактично, в деяких колоніальних державах почало вже виникати явище освічених безробітних.)

Загально визнано, що в піднесенні націоналізму на колоніальних територіях центральну роль відігравала інтелігенція, немалою мірою тому, що колоніалізм подбав, щоб місцеві аграрні магнати, великі торговці, промислові підприємці й навіть численний клас професіоналів були рідкістю. Майже

${ }^{2}$ Лише один приклад: у 1928 році майже 250,000 тубільців отримували платню в Голландській Східній Індії, й вони складали $90 \%$ всіх державних функціонерів. (Симптоматично, що суттєво різні зарплати й пенсії голландських і корінних службовців, складені докупи, з'їдали до 50\% державних видатків!) Див.: Amry Vandevbosch. The Dutch East Indies, pp. 171-173. Проте голландців серед бюрократів було в пропорційному відношенні вдев'ятеро більше, ніж англійців у Британській (не-“корінній”) Індії.

${ }^{3}$ Навіть в ультраконсервативній Голландській Індії кількість тубільців, які отримали початкову освіту західного стилю, збільшилася з близько 2,987 в 1900-1904 pр. до 74,697 у 1928 р.; а число тих, хто отримав середню західну освіту, зросло за той самий період з 25 до 6,468. Kahin. Nationalism, p. 31 . 


\section{ОСТАННЯ ХВИЛЯ}

скрізь економічна влада була або монополізована самими колоніалістами, або нерівномірно поділена з політично немічним класом (не-місцевих) бізнесменів-парій - ліванських, індійських і арабських у колоніальній Африці, китайських, індійських і арабських у колоніальній Азії. Не менш загально визнано й те, що авангардна роль інтелігенції була зумовлена ї̈ двомовною освіченістю, чи радше освіченістю та двомовністю. Друкарство й освіта дали вже можливість уявленій спільноті рухатись у однорідному, порожньому часі, про який ми згадували раніше. Двомовність означала доступ, через європейську державну мову, до сучасної західної культури в найширшому сенсі та, зокрема, до моделей націоналізму, національності й національної держави, вироблених протягом дев'ятнадцятого сторіччя ${ }^{4}$.

В 1913 р. голландський колоніальний режим у Батавії $з$ благословення Гааги спонсорував грандіозні загальноколоніальні урочистості на відзначення сторіччя "національного визволення" Нідерландів від французького імперіалізму. Були надані вказівки забезпечити фізичну присутність i фінансові внески не тільки голландських та євразійських громад, але й підлеглого корінного населення. Протестуючи, один із перших явансько-індонезійських націоналістів Суварді Сурджанінграт (Кі Гаджар Деванторо) опублікував у голландськомовній газеті свою відому статтю "Als ik eens Nederlander was" ("Якби одного разу я став голландцем")".

\footnotetext{
${ }^{4}$ За словами Ентоні Бернетта, це також "давало інтелектуалам змогу сказати своїм побратимам-співрозмовникам [які вживали корінні народні мови], що "ми" можемо бути подібними на "них".

${ }^{5}$ Оригінально вона з'явилась у "De Expres" 13 липня 1913 року, але була швидко перекладена на "індонезійську" й опублікована в місцевій пресі. Суварді тоді мав 24 роки. Незвично високоосвічений і прогресивний аристократ, він у 1912 році разом із яванцем незнатного походження докгором Тжіпто Мангоенкоесоемо та євразійцем Едуардом Дувесом Деккером утворив першу в колонії політичну партію, Indische Partij. Стислий, але цікавий аналіз постаті Суварді можна знайти в: Savitri Scherer. "Harmony and Dissonance: Early Nationalist Thought in Java", chapter 2. Там у I додатку подається англійський переклад славетної статті, звідки й узято цей уривок.
} 


\section{УЯВЛЕНІ СІІЛЬНОТИ}

На мою думку, $є$ щось недоречне - щось непристойне - в тому, шо ми (а я залишаюся в уяві голландцем) запрошуємо корінних мешканців приєднатися до святкувань нашої незалежності. По-перше, ми образимо їхні вразливі почуття, тому шо святкуватимемо власну незалежність в їхній рідній країні, яку ми колонізуємо. Ми зараз переповнені щастям, адже сто років тому звільнилися від іноземного панування; і все це відбувається на очах тих, хто досі знаходиться під нашим пануванням. Невже ми не розуміємо, що ці нешасні раби також прагнуть, як і ми, дістати змогу святкувати свою незалежність? Чи, може, завдяки своїй руйнівній політиці ми вже сприймаємо всі ці людські душі мертвими? Якшо це так, то ми вводимо себе в оману, адже, якою б примітивною не була спільнота, вона опирається будь-якому гнобленню. Якби я був голландием, я 6 не влаштовував святкування незалежності в країні, де в народу вкрали його незалежність.

Цими словами Суварді зміг повернути голландську історію проти голландців, зухвало здираючи шов, який з'єднував голландський націоналізм з імперіалізмом. Більше того, уявно перетворившись на час у голландця (тим самим пропонуючи своїм голландським читачам здійснити аналогічну трансформапію в тимчасових індонезійців), він підважував расистські підвалини голландської колоніальної ідеології.

Словесна атака Суварді - яка привела у захват його індонезійську аудиторію, роздратувавши водночас голландську - $є$ взірцем загальносвітового феномена XX ст. Адже парадокс імперського офіційного націоналізму полягав у тому, що він неухильно привносив у свідомість колонізованих народів те, що дедалі більше сприймалося й описувалося як європейські "національні історії" - причому робив це не лише завдяки випадковим непродуманим урочистостям, але й безпосередньо через читальні й класи'. Повз увагу в'єт-

\footnotetext{
${ }^{6}$ Зверніть туг увагу на повчальний зв'язок між “уявленими” й "уявними" спільнотами.

${ }_{7}$ Святкування 1913 року були досить характерні для офіційного напіоналізму і в іншому смислі. Як “національне визволення” відзнача-
} 
памських юнаків не могли пройти відомості про philosophes $\mathrm{i}$ Революцію, а також про те, що Дебре назвав "нашою секулярною ворожнечею до Німеччини" . Велика Хартія вільностей (Magпа Carta), Мати парламентів і Славетна Революція були включені в усьому лоску англійської національної історії до шкільних програм по цілій Британській Імперії. Бельгійську боротьбу за незалежність від Голландії було занесено до шшкільних підручників, за якими мали навчатися діти з Конго. Те саме відносилося до вивчення історії СІША у Філіппінах i, врешті-решт, Португалії в Мозамбіку й Анголі. Іронія, звісно, полягає в тому, що всі ці історії виписувалися з історіографічної свідомості, яка на зламі століть скрізь у Європі стала визначатися в термінах нації. (Барони, котрі ıав'язали Велику Хартію Іоанну Плантагенету, не розмовляли "англійською" й не усвідомлювали себе "англійцями", але через 700 років у шкільних аудиторіях Сполученого Королівства за ними вже міцно закріпилась репутація перших патріотів.)

Проте існувала й характерна особливість, що відрізняла пову націоналістичну інтелігенцію колоній від лінгвістично орієнтованої націоналістичної інтелігенції Європи XIX ст. Вона незмінно була дуже молодою й надавала цій своїй молодості специфічного політичного значення - значення, яке, попри всі зміни, що відбулися, не втратило своєї ваги до иинішнього дня. Піднесення (сучасного/організованого) бірманського націоналізму часто пов'язується із заснуванıям 1908 року Буддійської Асоціації Юнаків в Рангуні; а малайського - із утворенням 1938 року Kesatuan Melayu Muda (Союзу Малайської Молоді). Індонезійці щорічно відзначають Sumpah Pemuda (Клятву Юнацтва), яку склали й

лася, фактично, реставрація Оранської династії звитяжними військами Свяшенного Союзу (а не заснування 1795 року Батавської Республіки); шричому половина визволеної нації невдовзі відкололася, щоб утворити 1830 року Королівство Бельгію. Але Суварді, безперечно, засвоїв у своїй колоніальній школі саме зовнішній лиск "національного визволення".

8 "Marxism and the National Question", p. 41. 
якою заприсяглись учасники конгресу націоналістичної молоді 1928 року. І так далі. Абсолютно вірно, що в певному смислі з Європою це все сталося раніше - якщо ми згадаємо Молоду Ірландію, Молоду Італію й тому подібне. Як у Європі, так і в колоніях “молодь" і “юнацтво” були ознакою динамізму, прогресу, саможертовного ідеалізму й революційної волі. Але в Європі ця “молодь" не мала визначених соціолюгічних обрисів. Можна було бути людиною середнього віку й далі належати до Молодої Ірландії; можна було бути неписьменним і належати до Молодої Італії. Звичайно, причина полягала в тому, що ці націоналістичні рухи користувались або рідною мовою, якою учасники розмовляли від колиски, або, як у випадку з Ірландією, мовою метрополії, що протягом сторіч завоювання пустила такі глибокі корені серед частин населення, що також могла вже сприйматися народною, в креольському стилі. Таким чином, не існувало жодних незмінних зв'язків між мовою, віком, класом і статусом.

В колоніях усе було зовсім інакше. Під молоддю, насамперед, малося на увазі перие покоління, яке масово здобуло європейську освіту, відокремивши себе мовно й культурно від покоління своїх батьків, а також від основної маси своїх колонізованих ровесників (порівняймо з Б. Ч. Палом). Бірманська "англомовна" ҮМВА , змодельована частково 3 YMCA , була утворена школярами, що вміли читати поанглійськи. В Голландській Індії ми зустрічаємо, inter alia, Jong Java (Молоду Яву), Jong Ambon (Молоду Амбойну) i Jong Islamietenbond (Лігу Молодих Мусульман) - назви, незрозумілі для будь-кого з молодих тубільців, неознайомлених із колоніальним стилем мови. Отже, в колоніях під терміном "молодь" мали на увазі “освічену молодь", принаймні на початках. Це в свою чергу нагадує нам про унікаль-

\footnotetext{
Young Men Birman Association (Асоціація бірманської молоді) (прим. перекл.).

Young Men Chistian Association (Молодіжна християнська асоціація) (прим. перекл.).
} 
ну роль, яку відігравали колоніальні шкільні системи у підгримці колоніальних націоналізмів? .

Приклад Індонезії служить дивовижною ілюстрацією цььго процесу, не в останню чергу завдяки їі неймовірним розмірам, величезній кількості населення (навіть у колоні:льні часи), географічному подрібненню (близько 3,000 островів), релігійній строкатості (мусульмани, буддисти, католики, окремі протестантські групи, балінезькі індуси й "анімісти") та етнолінгвістичному розмаїттю (понад 100 різнорідних груп). Більше того, судячи з їі гібридної псевдоеллінської назви, вона навіть приблизно не співпадає територіально з будь-якими доколоніальними володіннями; зовсім

${ }^{9}$ Ми тут зосередимо свою увагу на цивільних школах. Але важливу роль відігравали також і їхні військові відповідники. Професійно укомплектована постійна армія, запроваджена на початку XIX ст. Пруссією, потребувала якшо не більш спеціалізованої, принаймні більш продуманої освітньої структури, ніж аналогічна цивільна. Молоді офіцери ("турки"), випускники нових військових академій, часто відігравали важливу роль у розвитку націоналізму. Показовим є приклад із майором Чукумою І Ізеогву, котрий керував переворотом у Нігерії 15 січня 1966 року. Християнин-ібо, він був серед першої групи молодих нігерійців, відправлених 1960 року після здобуття Нігерією незалежності на навчання до [вій('ькової академії] Сендхерсту з метою трансформування колоніального, вкомплектованого білими, найманого війська в національну армію. (Хоча він і навчався у Сендхерсті разом із майбутнім бригадним генералом Африやою, котрий, також у 1966 році, мав скинути сөій уряд, обидва тубільці були приречені повернутися на власну імперську батьківшину.) Разючим (відченням потужності Прусської моделі $є$ те, що він спромігся залучити війська мусульман-гауса до вбивства Сардауни з Сокото та інших мусульманських аристократів-гауса, і в підсумку розвалив уряд Абубакара Тафави Балеви, в якому домінували мусульмани-гауса. Не менш разючою ознакою націоналізму, породженого колоніальною школою, $є$ те, шо у своїй цромові по радіо Кадуна він запевняв своїх співвітчизників у тому, що "вам більше не треба буде стидатися, що ви нігерійці". (Цитата з: Anthony H. M. Kirk-Greene. Ciisis and Conflict in Nigeria: A Documentary Source $B o o k$, p. 126). Проте націоналізм ще недостатньо глибоко проріс у грунті ІІігерії, тому націоналістичний переворот Нзеогву був невдовзі витлумачсний як змова етнічних ібо; звідси й липневі військові заколоти, вересневі ĭ жовтневі погроми, спрямовані проти ібо, й відокремлення Б'яфри у травні 1967 року (див.: Robin Luckam. The Nigerian Military, passim). 


\section{УЯВЛЕНІ СПІЛЬНОТИ}

навпаки, до брутального загарбання в 1975 році генералом Сухарто колишнього Португальського Східного Тимору іiі кордони повністю відповідали тим, що залишилися після останніх голландських завоювань (близько 1910 р.).

Декотрі з народностей східного узбережжя Суматри не тільки розташовані у безпосередній фізичній близькості до населення західного берега Малайського півострова, адже їх розділяє лише вузька Малаккська протока, але й споріднені етнічно, розуміють мови один одного, поділяють спільну релігію тощо. Ці самі суматрійці не мають нічого спільного ні в мові, ні етнічності, ні релігії з амбонійцями, що мешкають на островах, розташованих за тисячі миль на схід. Проте в цьому сторіччі вони почали сприймати амбонійців як співвітчизників-індонезійців, а малайців - як чужинців.

Ніщо так не вплинуло на усвідомлення цього зв'язку, як школи, що на зламі століття в усе більших кількостях відкривалися режимом Батавії. Шоб зрозуміти чому, треба пригадати, що цілком на відміну від традиційних, місцевих шкіл, які завжди були локальними й індивідуальними закладами (навіть якщо, в чисто мусульманському стилі, там відбувалися постійні горизонтальні переміщення учнів від одного авторитетного вчителя-улами до іншого), урядові школи формували колосальну, добре продуману, чітко централізовану ієрархію, аналогічну за своєю структурою державній бюрократії. Уніфіковані підручники, стандартизовані дипломи й атестати, суворо відрегульована градація вікових груп, замкнутий, взаємопов'язаний світ пізнання. Та не менш важливою була й географія цієї ієрархії. Стандартні початкові школи були розкидані в селищах і маленьких містечках колонії; неповні й повні середні школи - в більших містах і провінційних центрах; тоді як вища освіта (верхівка піраміди) зосереджувалась у колоніальній столиці Батавії й побу-

\footnotetext{
${ }^{10}$ Ідея про те, шо певний учень може бути “застарим" для перебування в тому чи іншому класі, немислима в традиційній мусульманській школі, була підсвідомою аксіомою колоніальної школи західного типу.
} 


\section{ОСТАННЯ ХВИЛЯ}

дованому голландцями місті Бандунгу, на 100 миль південпозахідніше у прохолодних верхів'ях Пр іапгану. Таким 'ином колоніальна шкільна система ХХ ст. породила паломпицтва, аналогічні давнішим подорожам функціонерів. В ролі Риму для цих паломництв виступала Батавія: не Сінгапур, ще Маніла, не Рангун, навіть не старі яванські королівські столиці Джогджакарта й Суракарта ${ }^{11}$. 3 усіх куточків обширпої колонії, але не з-поза неї, молоді пілігрими рухалися до центру і вгору, зустрічаючи колег-пілігримів із різних, колись, можливо, ворожих селищ у початковій школі; з розмаїтих етнолінгвістичних груп у середній пкколі; та з кожної 'Іастини королівства у вищих учбових закладах столиці ${ }^{12}$. Й вони знали, що звідки б не прийшли, всі вони читали однакові книжки й вирішували однакові арифметичні задачі. Вони також знали, навіть не маючи певності, що туди діїдуть - i більшості це таки не вдавалося - що Римом була Батавія, і що столиця надавала "сенсу" всім цим мандрам, пояснюючи в результаті, чому "ми" є "тут" "разом". Інакше кажучи, їхній спільний досвід і товарисько-суперницькі стосунки в аудиторіях надавали картам колонії, які вони нивчали (завжди розфарбованим інакше, ніж Британська Малайя чи Американські Філіппіни), специфічно територіілльної реальності, уявної, але підтверджуваної щодня різиими акцентами й типами облич їхніх однокласників ${ }^{13}$.

I ким же вони були всі разом? Для голландців тут усе було ясно: якою б не була їхня рідна мова, вони залишались

11 Пізніше, звичайно, верхом устремлінь стали Гаага, Амстердам і Лсйден; проте лише невеличка жменька могла серйозно мріяти про шівчання в цих містах.

${ }^{12}$ Будучи світськими, школи ХХ ст. мали в основному систему "пільного навчання, хоча хлопців там була абсолютна більшість. Звідси "юбовні романи й досить часті одруження “просто зі шкільної парти”, які 'унеречили всім родовим традиціям.

Сукарно вперше побачив Західний Іріан, за який він так вперто (ю)ровся, коли йому було вже понад 60 років. Тут, як і в прикладі зі пнсільними картами, ми бачимо, шо вимисел перетікає в реальність - порів. "Noli" та "El Periquillo Sarniento". 
невиправними inlanders, і це слово, як і англійське "natives" (корінні, тубільці) або французьке "indigenes", завжди несло на собі неумисно парадоксальне семантичне навантаження. В цій колонії, як і в будь-якій іншій, окремій колонії, воно означалю, що особи, до котрих так звертаються, були водночас “підлеглими” й "належними там” (так, як голландці, що є “корінними мешканцями” Голландії, належать саме там). I навпаки, вживаючі такі вирази голландці відносили себе до тих, хто має зверхність і “там не належить”. Це слово також означало, що у своїй загальній підлеглості inlanders були однаково нікчемними, незалежно від того, з якої етнолінгвістичної групи чи класу вони походили. Проте навіть ця жалюгідна рівність суспільного стану мала свій визначений периметр. Адже inlander завжди задавав собі питання: “корінний він мешканець чого?”. Якщо голландці часом говорили про inlanders як про певну світову категорію, то досвід показував, що подібна точка зору не підтверджується практикою. Inlanders були обмежені визначеними кордонами колонії. За їі межами знаходились, зокрема, natives, indigenes та indios. Крім того, колоніальна юридична термінологія включала таку категорію, як vreemde oosterlingen (іноземні мешканці Сходу), що мала в собі сумнівний призвук фальшивої монети - подібно до "іноземних корінних менгканців”. Такі “іноземці зі Сходу”, в основному китайці, араби й японці, хоча й жили в колонії, мали проте вищий від "коріІ них тубільців” політико-правовий статус. Більше того, малесенька Голландія відчула таке благоговіння перед економічною силою й військовою доблестю олігархів Мейдзі, щи японці колонії отримали від 1899 року легальний статус "почесних європейців". Поступово викристалізовуючись 3 усього цього, inlander - відокремившись від білих, голлан - $^{-}$ ців, китайців, арабів, японців, natives, indigenes та indios ставав усе специфічнішим за своєю суттю; аж зрештою, немов дозріла личинка, він раптом перетворився в ефектног метелика під назвою "індонезієць".

Хоч вірно, шо поняття inlander і "тубілець" ніколи п" могли б стати по-справжньому узагальнюючими расистськи- 
ми концепціями, тому що завжди припускали закорінення в якомусь специфічному середовищі ${ }^{14}$, у випадку з Індонезісюо не варто гадати, що кожне "тубільне" середовище мало наперед визначені й непорушні кордони. У протилежному нас переконують такі два приклади: Французька Західна Африка й Французький Індокитай.

У часи свого розквіту, Ecole Normale William Ponty в Дакаpi, всього-навсього середня школа, була, однак, вершиною колоніальної освітньої піраміди у Французькій Західній Африці $i^{15}$. Школу Вільяма Понті відвідували тямущі учні з теперішніх Гвінеї, Малі, Берегу Слонової Кості, Сенегалу тощо. Не треба, отже, дивуватися, що паломництва цих хлоп'Іаків, що завершувались у Дакарі, описувалися в термінах (Dранцузької [Західної] Африки, незабутнім символом якої було парадоксальне поняття negritude - суть африканства, ॥ю передається тільки французькою, тобто мовою аудиторій школи Вільяма Понті. I все-таки вищість школи Вільяма ІІонті була випадковою й ефемерною. Чим більше будувалогя середніх шкіл у Французькій Західній Африці, тим меншою ицявлялася потреба для кмітливих юнаків вирушати в таке далеке паломництво. Та й високому освітньому значенню школи І іільяма Понті ніколи не відповідало адміністративне значення Цакару. Західноафриканські юнаки, що звільняли парти шко-

14 Порівняймо, для контрасту, “полукровок" або "негритосів", які, i'явившися спочатку в Кале, могли потім вигулькнути в будь-якій точці иланети за межами Сполученого Королівства.

Щодо першопочатків і розвитку цієї відомої школи, див.: Abdou Moumouni. L'Education en Afrique, pp. 41-49; щодо їі політичної ваги: Ruth Schachter Morgenthau. Political Parties in French-Speaking West Africa, pp. 12-14, 18-21. Не маючи спочатку назви, ecole normale знаходилася в СентЛyї, тоді 1913 року була перенесена в Горе, передмістя Дакару. Згодом їі пізвали на честь Вільяма Мерло-Понті, четвертого генерал-губернатора ( 1908-1915) Французької Західної Африки. Серж Тійон повідомив мені, пю ім'я Вільям (на відміну від Гійом) довгий час було популярним в районі (ирдо. Безперечно, він має слушність у тому, шо приписує цю популярпість історичним контактам з Англією завдяки виноторгівлі; проте цілком імовірно, що своїми коренями вона сягає тієї доби, коли Бордо (Гієнь) ще було невід'ємною частиною королівства, керованого з Лондона. 
ли Вільяма Понті, не знаходили місця в бюрократії колоніальної адміністрації Французької Західної Африки. Отож, старі шкільні друзі, повертаючись додому, ставали згодом гвінейськими або малійськими націоналістичними лідерами, зберігаючи між тим "західноафриканський” дух товариськості й спільної близькості, втрачений наступними поколіннями ${ }^{16}$.

Схожим чином, в очах одного покоління відносно добре освічених юнаків курйозний гібрид "Індокитай" мав істинний, підтверджений досвідом, уявлений сенс ${ }^{17}$. Це утворення, варто нагадати, офіційно утворилося лише 1887 року, а своєї остаточної територіальної форми набуло тільки 1907 року, хоча активне втручання Франції розпочалося в цьому регіоні століттям раніше.

Загалом кажучи, освітня політика, здійснювана колоніальними правителями “Індокитаю”, переслідувала дві фундаментальні мети ${ }^{18}$ - обидві 3 яких, як виявилося, сприяли

${ }^{16}$ Здається, нічого подібного не було в Британській Західній Африці можливо, тому, що британські колонії не були суміжними, або тому, що Лондон був достатньо заможнім і ліберальним, щоб відкрити середпі школи майже одночасно в головних територіях, або в силу провінціалізму конкуруючих протестантських місіонерських організацій. Середня школі Ачімота, заснована 1927 року в Аккрі колоніальною владою, швидко сталі своєрідною верхівкою освітньої піраміди Золотого Берега, а після здобуття незалежності діти урядових міністрів саме там почали навчатись, як статІІ спадкоємцями своїх батьків. Ӵ̈ конкурент, середня школа Мфанціпім, маліі перевагу в тому, що була закладена раніше (1876 року), але серед їі недоліків було місце знаходження (Кейп Коуст) і напівнезалежність від держави (вона лишалася релігійною навіть довгий час після незалежності). Цією інформацією я завдячую Могамеду Чамбасу.

${ }_{17}^{17}$ Це привело, interalia, до створення однією генерацією (1930-1951?) Комуністичної партії Індокитаю, до якої деякий час належала молодь рідною мовою котрої могла бути в'єтнамська, кхмерська чи лаоська. Нипі формування цієі партії розглядається часом просто як вияв “давнього в'єтнамського експансіонізму". Насправді, вона була витворена Комілтерном на основі освітньої (й до деякої міри адміністративної) системи Французького Індокитаю.

${ }^{18}$ Ця політика вправно й детально розглядається в: Gail Paradise Kelly, Franco-Vietnamese Schools, 1918 to 1938. На жаль, автор зосереджуєтьсз винятково на в' $€$ тнамомовному населенні Індокитаю. 
росту “індокитайської" свідомості. Одним із намірів було намагання розірвати існуючі політико-культурні зв'язки між колонізованими народностями й безпосереднім поза-індокитайським світом. Стосовно "Камбоджі" й “Лаосу" , мішенню був Сіам, який раніше різною мірою здійснював над ними сюзеренітет і поділяв ритуали, атрибути й сакральну мову Хінаяна-буддизму. (До того ж, мова й писемність низовинних лао й тайців були й залишаються близько спорідненими.) Саме тому французи проводили в цих регіонах, останwix, захоплених від Сіаму, свої перші експерименти з так званими "відновленими школами-пагодами", що були задумані з метою переміщення кхмерських ченців та їхніх учнів із тайської сфери впливу в індокитайську ${ }^{20}$.

У Східному Індокитаї (до якого я відношу "Тонкін”, "Аннам" і “Кочин-Китай”) мішенню став сам Китай і китайська цивілізація. Хоча правлячі в Ханої й Хуа династії столітгями боронили свою незалежність від Пекіна, їхнє правління базувалося на мандаринаті, свідомо скопійованому з китайського. Набір до державного апарату залежав від результатів письмових іспитів з конфуціанської класики; династичні доку-

19 Я вживаю цю досить незграбну термінологію, шоб підкреслити колоніальне походження цих утворень. "Лаос" було зібрано з цілого грона ворогуючих князівств, між тим понад половину лао-мовного населення :алишено в Сіамі. Кордони "Камбоджі" не відповідали ні будь-якій южемій історичній території доколоніального королівства, ні розташуванІІо кхмеро-мовних народностей. Сотні тисяч представників цих народностей опинилися в пастці “Кочин-Китаю”, утворивши з часом окрему спільноту, відому як Khmer Krom (кхмери низів'я ріки).

Задля цієї мети вони в 1930-х роках заклали в Пномпені Ecole Superieure de Pali, духовний коледж, який відвідували як кхмеро-, так i ла-мовні ченці. Спроба відвернути увагу буллистів від Бангкока виявилася не зовсім успішною. В 1942 році (невдовзі після того, як Сіам, підтриманий японцями, відновив свій контроль над більністю північно-західної "Камбоджі") французи заарештували шановного професора цього коледжу за володіння й поширення "підривних" тайських освітніх матеріалів. (Найімовірніше, що цими матеріалами являлися деякі з виразно націоналістичних шкільних підручників, виданих відверто анти-французьким режимом фельдмаршала Плаека Фібунсонгхрама (1938-1944). 


\section{УЯВЛЕНІ СІІІЬНОТИ}

менти складалися китайськими ієрогліфами; а правлячий клас був глибоко просякнутий китайською культурою. Ці тривалі зв'язки набули ще більш небажаного характеру після 1895 року, коли через північний кордон колонії почали проникати писання таких китайських реформаторів, як Кан Ю-вей і Лянг Ци-чао, та націоналістів типу Сун Ят-сена". Відповідно, конфуціанські іспити були почергово скасовані в "Тонкіні" 1915 та в "Аннамі" 1918 року. Відтоді набір до цивільних служб Індокитаю проводився винятксво за посередництвом французької колоніальної освітньої системи, що почала розвиватись. Більше того, латинізований фонетичний шрифт quôc ngū, винайдений ще у XVII ст. місіонерамиєзуїтами й запроваджений владою для вживання в "КочинКитаї" вже в 1860-х роках, був свідомо заохочуваний для розриву контактів із Китаєм - а також, можливо, з тубільним минулим - адже тепер династичні пам'ятки й древня література ставали недоступними новій генерації колонізованих в'єтнамців ${ }^{23}$.

${ }^{21}$ David G. Marr. Vietnamese Tradition on Trial, 1920-1945, p. 146. Hc менш загрозливими були й контрабандні китайські переклади таких бентежних французьких авторів, як Руссо. (Kelly. "Fraпco-Vietnamese Schools", p. 19).

${ }^{22}$ У своій остаточній формі створення цього шрифту приписується, звичайно, талановитому лексикографу Александру де Родсу, який 1651 року опублікував свій чудовий "Dictionarium annamiticum, lusitanum et latinum".

${ }_{23}$ "[Більшість] французьких колоніальних посадовців кінця ХІХ ст. ...були переконані, шо досягнення тривкого успіху в колонізації вимагало суворого обмеження китайських впливів, включаючи систему письма. Місіонери часто вважали освічених конфуціанців головною перешкодою для загального католицького навертання В'єтнаму. Отож, на іхню думку, усунення китайської мови водночас ізольовувало 6 В'єтнам від цієї спадщини й нейтралізувало б традиційну еліту". (Marr. Vietnamese Tradition, p. 145). Келлі наводить слова одного з колоніальних письменників про те, шо “фактично, саме лише вивчення quoc пgu... приведе до поширення серед в'єтнамців тільки французької писемності, літератури й філософії, чого ми й бажаємо. Тобто, щоб вони мали доступ до тих творів, які ми вважаємо для них корисними й легко засвоюваними: лише до тих текстів, які ми транскрибуємо в quoc ngu". "Franco-Vietnamese Schools", p. 22. 
Другою метою освітньої політики було створення ретельно вивіреної кількості франкомовних і франкописемних індокитайців, які б виконували роль політично надійної, вдячної й культурно асимільованої корінної еліти, яка поІговнювала б нижчі ланки колоніальної бюрократії й великих комерційних підприємств ${ }^{24}$.

Ми тут не будемо затримуватись на тонкощах колоніальıої освітньої системи. 3 точки зору нашої теми, ключовою характеристикою була ӥі цілісна, хоча й хитка, пірамідальна структура, верхні щаблі якої до середини 1930-х років знаходилися на сході території. До того часу, наприклад, єдині спонсоровані державою lycees були розташовані в Ханої й Сайгоні; а єдиний в довоєнному Індокитаї університет знаходився Ханої, так би мовити, “в двох кроках" від палацу геиерал-губернатора ${ }^{2 .}$. Щаблі цієї системи долали всі головні посії національних мов у французьких володіннях: в'єтнамці, китайці, кхмери й лаосці (а також досить багато молодих (ранцузів, мешканців колонії). Для цих вихідців, скажімо, 3 Май Тхо, Баттамбангу, В'єнтньяну й Віню, ця зустріч мала означати "індокитайськість", аналюгічно до того, як багатомовне й поліетнічне студентство Батавії й Бандунгу свою конвергенıію сприймало як “індонезійськість” . Ця індокитайськість,

${ }^{24}$ Див.: ibid., pp. 14-15. Для численніших нижчих верств індокитайського населення генерал-губернатор Альбер Сарро (автор Кодексу громадської освіти 1917 року) наполягав на "простій освіті, зведеній до основ, яка б давала дитині змогу навчитися всьому корисному, по їй необхідно знати в її скромній кар'єрі фермера чи ремісника для поліпшення ıриродних і соціальних умов іï існування". Ibid., р. 17.

1937 року всього зарахували 631 студента, з них 580 на факультети права й медицини. Ibid., p. 79; також див. стор. 69-79, де описується дивна історія цього закладу, заснованого 1906 року, закритого 1908, знову відкритого 1918, який ніколи, до кінця 1930-х років, не переріс рамки популярного професійного коледжу.

Враховуючи те, що надалі я зосереджусь на кхмерах і в'єтнамцях, можливо, варто в цьому місці коротко згадати декого з видатних лаосців. Нинішній прем'єр-міністр Лаосу Кайсон Фумвіган відвідував наприкінці 1930-х років медичний факультет Ханойського університету. Глава лержави принц Суфанувонг, перш ніж отримати диплом інженера у 


\section{УЯВЛЕНI СНIЛЬНОТИ}

хоча й цілком реальна, панувала в уяві нечисленної групи i впродовж короткого часу. Чому вона виявилась такою ефемерною, тоді як індонезійськість вижила й поширилась?

По-перше, починаючи десь від 1917 року, відбулась очевидна зміна в спрямуванні колоніальної освіти, особливо на сході Індокитаю. Ліквідація традиційної конфуціанської екзаменаційної системи (або її загроза) підштовхувала чимраз більшу кількість представників в'єтнамської еліти до спроб влаштувати власних дітей в найкращі доступні французькі школи, цоб забезпечити їм бюрократичне майбутнє. Висока конкуренція за місця в небагатьох добрих школах викликала особливо сильну реакцію colons, які вважали, шо ці заклади по праву є переважно французьким заповідником. Колоніальний режим вирішив цю проблему, створивши окрему й підпорядковану “франко-в'єтнамську” структуру освіти, яка в початкових класах спеціально акцентувала на в’єтнамомовному викладанні за допомогою quôc ngü (причому французька вивчалася за допомогою quôc $n g \bar{u}$ як друга мова)" Ця зміна курсу мала два взаємодоповнюючих наслідки. 3 од-

Франції, закінчив Ханойський ліцей Альбера Сарро. Його старший брат принц Фетсарат Ратанавонгса, який від жовтня 1945 по квітень 1946 року перебував на чолі нетривалого антиколоніального в'єнтньянського уряду Lao Issara (Вільне Лаo), в юності закінчив Сайгонський Lycee ChasseloupLaubat. Напередодні Другої світової війни найвишим освітнім закладом "Лаосу" був маленький College [тобто неповна середня школа] Pavie у В'єнтьяні. Див.: Joseph J. Zasloff. Pathet Lao, pp. 104-105; і "3349" [псевдонім Фетсарата Ратанавонгси], Iron Man of Laos, pp. 12, 46. Показовим, на моюо думку, $€$ те, що у своїх спогадах про останні дні навчання в Парижі Фетсарат постійно, сам того не усвідомлюючи, називає своїх лаоських, кхмерських і в'єтнамських однокласників “індокитайськими студентами”. Див., наприклад: ibid., pp. 14-15.

2i Таким чином у раніше "цілісних" lycees Шосслу-Лоба й Альбера Сарро в 1917-1918 роках були введені нестандартні "місцеві відділення". Ці “місцеві відділення" пізніше перетворилися відповідно в Lycee Petrus Ку та Lycee du Protectorat. (Ibid., pp. 60-63). Проте меншина привілейованих indigenes продовжувала відвідувати "справжні французькі" lycees (юний Нородом Сіанук обрав ліцей Шосслу-Лоба), тоді як “французька” меншина (головним чином, євразійці й місцеві з французьким легальним статусом) відвідувала ліцей Petrus Ку та споріднені заклади в Ханої. 
ного боку, публікація урядом сотень тисяч підручників з quôc $n g \bar{u}$ значно прискорила поширення цього вигаданого європейцями письма, посприявши перетворенню його між 1920 i 1945 рр. в головний засіб виразу в'єтнамської культурної (й національної) солідарності ${ }^{28}$. Адже хоча лише $10 \%$ в'єтнамомовного населення наприкінці 1930 -х років вміло писати, це була безпрецедентно велика частка в історії цього народу. Більше того, всі ці письменні, на відміну від освічених конфуціанців, були глибоко зацікавлені в стрімкому зростанні своїх лав. (Подібним чином, хоча й не з таким розмахом, влада в "Камбоджі" й “Лаосі" заохочувала дpyжyвання народномовних підручників для початкових шкіл, спочатку вживаючи в основному традиційний правопис, а пізніше потроху переходячи до латинізованого алфавіту) 3 другого боку, ця політика була спрямована на усунення некорінних в'єтнамомовних мешканців, що проживали в Східному Індокитаї. Вона спрацьовувала, скажімо, з такою спільнотою, як Кхмер Кром із “Кочин-Китаю”, особливо в поєднанні з готовністю колоніального режиму забезпечити ï “франко-кхмерськими" початковими школами, подібними до тих, що заохочував Протекторат, щоб звернути їхні горивання назад до верхів'я Меконгу. Таким чином ті юнаки 3 Кхмер Крому, котрі прагнули отримати вищу освіту в адміністративній столиці Індокитаю (а для декотрих вибраних це навіть могла бути Франція), все частіше вибирали обхідний шлях через Пномпень, аніж пряму дорогу до Сайгона.

По-друге, 1935 року College Sisowath в Пномпені був піднесений до рівня повноцінного державного lycee, $з$ рівним

\footnotetext{
${ }^{28}$ Марр зазначає, що в 1920-х роках “навіть найоптимістичніший із ıредставників інтелігенції [відданої quôc ngü] не міг би уявити, що через якихось два десятиріччя громадяни Демократичної Республіки В'єтнам матимуть змогу вести всі важливі справи - політичні, військові, економічиi, наукові й академічні - розмовною в'єтнамською мовою, сполученою з письмовою системою quoc ngü. Vietnamese Tradition, p. 150. Це стало пеприємною несподіванкою також і для французів.

${ }^{29}$ Показово, що одним із перших питань, піднятих кхмерськими націоналістами кінця 1930-х років, була "загроза" так званої “quoc ngu-ізації" кхмерського письма з боку колоніальної влади.
} 


\section{УЯВЛЕНІ СПІЛЬНОТИ}

статусом та ідентичною навчальною програмою порівняно 3 державними lycees Сайгона й Ханоя. Хоча студентів спочатку переважно набирали (згідно з традиціями цього College) з родин місцевих китайсько-кхмерських купців і в'єтнамських функціонерів, процент корінних кхмерів постійно зростав . Мабуть, справедливо буде зазначити, що після 1940 року основна маса кхмеромовних юнаків здобула пристойну середню французьку освіту в затишній колоніальній столиці, побудованій колоніалістами для сімейства Нородомів.

По-третє, не існувало справжнього ізоморфізму між освітніми й адміністративними паломництвами Індокитаю. Французи не приховували свого ставлення до в'єтнамців, які, попри свою ненадійність і жадібність, вважались, однак, набагато активнішими й кмітливішими від "інфантильних" кхмерів і лаосців. Відповідно, вони широко використовували в'єтнамських чиновників у західному Індокита1 ${ }^{31}$. 19з/ року 176.000 в'єтнамців у “Камбоджі" - котрі становили менше одного процента від 19-тимільйонного в'єтнамомовного населення колонії, але майже 6 процентів мешканців Протекторату - творили цілком успіпну громаду, для якої, як і для 50,000 відправлених перед 1945 р. до “Лаосу”, Індокитай означав багато. Зокрема, для службовців з іх числа, яких переміщали з місця на місце в $y$ сіх п'яти підрозділах колоніі Вони цілком могли уявити Індокитай як широку сцену, ні: якій ім випало грати.

Цей образ значно складніше давався лаоським і кхмерським чиновникам, хоча для них і не існувало формальноі

${ }^{30}$ В'єнтньян не відразу почав наслідувати цю модель. За даними Т(э) протягом 1930-х років лише 52 лаосця закінчили College іякий віп помилково називає Lycee] Pavie, порівняно з 96 в'єтнамцями. Laos, p. 位

з1 Ймовірно, шо все це відбувалося паралельно з упровадженшям франко-в'єтнамської шкільної системи, відмежовуючи в єтнамців піл суперництва 3 французькими громадянами в розвиненіших східншх частинах Індокитаю. В 1937 році в "Кочин-Китаї", "Аннамі" и "Тонкі1і" проживало 39,000 європейців, тоді як у разом взятих “Камбоджі" и "Јаосі лише 3,100. Marr. Vietnamese Tradition, p. 23. 
або легальної заборони індокитайської кар'єри. Навіть найчестолюбніші юнаки, вихідці з майже 326-тисячного (1937) народу Кхмер Кром у Східному Індокитаї (який складав чи не $10 \%$ усього кхмеромовного населення), з'ясовували, що на практищі вони мали дуже обмежені кар'єрні перспективи за межами “Камбоджі". Таким чином, кхмери й лаосці могли сидіти поруч із в'єтнамцями у франкомовних середніх і вищих школах Сайгона й Ханоя, але в них було небагато шансів зайняти тут рівні з ними адміністративні посади. Як і юнакам із Котону чи Абіджану в Дакарі, ім судилося після завершення навчання вертатися назад, “додому”, тобто до місця, визначеного їм колоніалізмом. Інакше кажучи, якщо їхні освітні паломництва спрямовувались до Ханоя, то адміністративні подорожі завершувалися для них в Пномпені та В'єнтньяні.

3 клубка цих протиріч і виринули ті кхмеромовні студенти, які пізніше залишилися в пам'яті першими камболжійськими націоналістами. Людина, яку можна слушно вважати "батьком" кхмерського націоналізму, Сон Нгок 'Гань, був, про що свідчить його в'єтнамське ім'я, кхмер кромом, який навчався в Сайгоні та деякий час займав дрібну суддівську посаду в цьому місті. Але в середині 1930-х років нін залишив Париж дельти Меконгу в пошуках перспектив॥ішого майбутнього у свому Блуа. Принц Сисоват Ютевонг відвідував середню школу в Сайгоні, перш ніж вирушити до (ग)анції для подальшого навчання. Повернувшись до Пномпеня через п'ятнадцять років, після Другої світової війни, «ін допоміг заснувати (Кхмерську) Демократичну партію й у 1946-1947 рр. займав пост прем'єр-міністра. Його міністр оборони, Сонн Веуннсай, відбув практично тотожну подоююж. Гуй Кантул, демократичний прем'єр-міністр у 19511952 рр., закінчив 1931 року école normale в Ханої, тоді I1овернувся до Пномпеня, де згодом став викладати у Lycée Sisowath $^{32}$. Мабуть, найпоказовішою з усіх є постать Йо

${ }^{32}$ Біографічні матеріали про цих людей мені люб'язно надав Стів Гедер. 


\section{УЯВЛЕНІ СІІЛЬНОТИ}

Кеуса, першого в скорботному ряді замордованих кхмерських політичних лідерів ${ }^{33}$. Народившись у провінції Баттамбанг 1905 року - коли нею ще правив Бангкок - він спочатку відвідував місцеву "реформовану школу-пагоду", а згодом вступив до "індокитайської" початкової школи в місті Баттамбангу. В 1921 році він продовжив навчання в College Sisowath у столиці Протекторату, а тоді в college de commerce в Ханої, який закінчив 1927 року одним із кращих у своєму класі з французькою мовою викладання. Сподіваючись вивчати хімію в Бордо, він подався на стипендію й отримав їі. Але колоніальна держава перешкодила його виїзду за кордон. Він повернувся до рідного Баттамбанга, де відкрив аптеку і працював у ній навіть після того, як Бангкок повернув собі цю провінцію 1941 року. Після поразки Японії в серпні 1945 року він знову опинився в "Камбоджі", тепер у ролі демократичного парламентарія. Варто зазначити, що він був безпосереднім нашадком блискучих філологів ранньої Європи, оскільки винайшов клавіатуру для друкарської машинки з кхмерським шрифтом і опублікував вагомий двотомник "Pheasa Khmer"[Кхмерська мова] або, як оманливо зазначено на титульній сторінці видання 1967 року, "La Langue Cambodgienne (Un Essai d'etude raisonne)" Але цей текст - лише перший том - з'явився 1947 року, коли його автор вже був головою Конституційної Асамблеї в Пномпені, а не 1937, коли він ше животів у Баттамбангу й коли Lycee Sisowath ще не підготував жодних кхмеромовних lyceens, а Індокитай залишався ефемерною реальністю. У 1947 році вже ніхто з кхмеромовних учнів - принаймні, вихідців із "Камбоджі" - не відвідував класів у Сайгоні чи Ханої. На сцену виходило нове покоління, для якого "Індокитай” був історією, а "В’єтнам” - реальною іноземною країною.

${ }^{33}$ Він загинув 1950 року в результаті вибуху гранати у штабі Демократичної партії, до якого була причетна невідома, але, ймовірно, знатна особа.

${ }^{34}$ Випуцено в Пномпені видавництвом “Librairie Mitserei” [Вільні друзі]. “Оманливо”, бо цілий текст написаний кхмерською мовою. Біографічні подробиці щодо Йо Кеуса, взяті з його пам'ятної кремаційної книги 1964 року, люб'язно мені передав Стів Гедер. 


\section{ОСТАННЯ ХВИЛЯ}

Це правда, що брутальні загарбания й окупапії, які відбувалися протягом XIX ст. за наказами правителів Нгуєнської династії в Хуа, залишили гіркі спогади в народній пам'яті кхмерів, включаючи мешканців того "Кочин-Китаю", якому судилося стати частиною В'єтнаму. Проте подібні настрої існували й у Голландській Індії: сунданійці ворогували з яванцями; батакці з мінангкабайцями; сасакці з балійцями; тораджійці з бугінійцями; яванці з амбонійцями тощо. Так звана "федералістська політика", яку проводив між 1945 і 1948 роками грізний віце-генерал-губернатор Губертус ван Моок з метою розвалу ше незміцнілої Індонезійської Республіки, якраз і намагалась використовувати ці непорозуміння ${ }^{2}$. Проте, незважаючи на цілу зливу етнічних повстань майже в усіх частинах незалежної Індонезії в період між 1950 і 1964 роками, "Індонезія" вціліла. Частково це сталося тому, що Батавія до самого кінця залишалася освітнім центром, до того ж, колоніальна адміністративна політика не заохочувала відсилання освічених сунданійців назад до "Сундаляндіi" або батакців до гір Північної Суматри, звідки вони походили. Практично всі головні етнолінгвістичні групи були наприкінці колоніального періоду призвичаєні до думки про існування на архіпелазі великої сцени, на якій для всіх них знайдеться відповідна роль. Таким чином, лише одне з повстань 1950-1964 років переслідувало сепаратистські цілі; решта займалися з'ясовуванням відносин у межах єдиної індонезійської політичної системи ${ }^{36}$.

Крім цього, не можна ігнорувати того курйозного факту, що в 1920-х роках з'явилася “індонезійська мова”. Це сталося

${ }^{35}$ Див.: Kahin. Nationalism, chapter 12; Anthony Reid. The Indonesian National Revolution, 1945-50, chapter 6; and Henri Alers. Om een rode of groene Merdeka, passim.

${ }^{36}$ Винятком була недовговічна Південномолуккська Республіка. Довгий час до репресивної колоніальної армії набирали у великих кількостях християнізованих амбонійців. Багато хто з них боровся під проводом ван Моока проти новонародженої революційної Індонезійської Республіки; після визнання в 1950 році Голландісю індонезійської незалежності, вони мали підстави очікувати не надто приємне майбутнє. 
настільки повчально, що варто зробити короткий відступ. Раніше ми вже згадували той факт, що голландська мова стала вживатися в управлінні Східною Індією досить пізно дуже обмежено. Інакше й не могло бути, адже голландці розпочали свої завоювання на початку XVII ст., а викладанням голландської мови для inlanders ніхто серйозно не займався до початку XX ст. Сталося так, що повільно й переважно стихійно на основі давньої міжострівної lingua fraпса виникла дивна адміністративна мова . Отримавши назву dienstmaleisch (щось типу "службової" чи "адміністративно малайської мови”), типологічно вона була близька таким мовам, як "Османська" або така собі "фіскальна німецька", що народилась у багатомовних казармах імперії Габсбургів ${ }^{38}$. На початку XIX ст. вона вже посідала значне місце в бюрократичному апараті. Коли в другій половині століття на сцену вийшло у достатньому обсязі капіталістичне друкарство, ця мова заполонила собою ринок і засоби інформації. Спочатку їі вживали переважно китайські й євразійські газетярі та друкарі, але наприкінці століття їі підхопили inlanders. Dienst-відгалуження їі родового дерева була досить забута й замінена фіктивним предком із островів Р'яу (найважливіший з яких став після 1819 року - мабуть, на щастя - Британським Сінгапуром). Сформована двома поколіннями міських письменників і читачів, вона вже була готова для визнання її 1928 року “Молодою Індонезією" національною (націоналістичною) мовою bahasa Indonesia. 3 того часу вона вже ніколи не озиралася назад.

Утім, приклад Індонезії, яким би цікавим він не був, не мусить схиляти до висновку, що коли б Голландія була мо-

${ }^{37}$ Див. цікавий опис у: John Hoffman. "A Foreign Investment: Indies Malay to 1902", Indonesia, 27 (April 1979), pp. 65-92.

${ }^{38}$ Військові “становили щось типу позанаиіональної касти, члени якоі навіть у приватному житті відрізнялися від свого національного оточент й дуже часто розмовляли на специфічній мові, так званій ararisch deutsch ("фіскальній німецькій"), як їі іронічно прозвали німецькі літератори, маючл на увазі під цим дивну лінгвістичну суміш, шо не надто серйозно ставилася до граматичних правил”. Jászi. The Dissolution, p. 144. Виділено автором. 


\section{ОСТАННЯ ХВИЛЯ}

гутнішою державою ${ }^{39}$ і здобула Індопезію 1850 року замість 1600 , голландська мова з таким же успіхом не могла б стати для неї національною. Ніщо не свідчить про те, що націоналізм Гани є менш справжній, ніж індонезійський тільки тому, що його національною мовою є англійська, а не ашанті. Завжди помилково вважати мови, подібно до деяких націоналістичних ідеологій - символами нації, такими як прапори, одяг, народні танці тощо. Багато важливішою є здатність мови творити уявлені спільноти, вибудовуючи в результаті специфічні солідарні об'єднання. Зрештою, імперські мови залишаються народними, тобто певними народними мовами серед багатьох інших. Якщо радикальний мозамбіканець говорить португальською мовою, важливим $\epsilon$ те, що португальська є засобом, завдяки якому уявлюється Мозамбік (обмежуючи водночас можливість його проникнення до Танзанії й Замбії). Під цим кутом зору вживання португальської мови в Мозамбіку (чи англійської в Індії) в основі своїй нічим не відрізняється від уживання англійської в Австралії або португальської в Бразилії. Мова не $є$ інструментом відлучення: в принципі, кожен може вивчити будь-яку мову. Зовсім навпаки, вона служить місії приєднання, обмеженій тільки фатальною спадщиною Вавилонської вежі: ніхто не живе настільки довго, щоб вивчити всі мови. Націоналізм винайдений мовою друку, а не якоюсь окремою мовою per se ${ }^{40}$.

${ }^{39}$ I не лише в очевидному сенсі. Через те, шо у XVIII й XIX ст. Голландія, по суті, володіла лише однією колонією, причому величезною й шрибутковою, цілком доцільним було навчати ії чиновників (єдиної) пеєвропейської diensttaal. 3 часом у метрополії з'явилися спеціальні иколи й факультети для мовної підготовки майбутніх функціонерів. Для багатоконтинентальних імперій типу Британської ніколи б не вистачило чциної місцевої diensttaal.

40 Дуже показовим шодо цього $є$ зроблений Марром опис розвитку мови у Східному Індокитаї. Він зазначає, що ще близько 1910 року "більпість освічених в'єтнамців ставилися до китайської чи французької мови, або до них обидвох, як до необхідних засобів «вищого» спілкування". (Vietnamese Tradition, p. 137). Після 1920 року, однак, частково в результаті лержавного впровадження фонетичного шрифту quôc ngū, все швидко ıмінилося. В той час “зростала віра в те, по розмовна в'єтнамська мова 


\section{УЯВЛЕНІ СІІЛЬНОТИ}

Єдиним питанням стосовно таких мов, як португальська в Мозамбіку й англійська в Індії, було те, чи здатні адміністративна й освітня системи (особливо остання) створити політично необхідний рівень двомовності. Тридцять років тому майже ніхто з індонезійців не вживав bahasa Indonesia як рідну мову; практично в кожного була своя "етнічна" мова, а дехто, особливо учасники національного руху, використовували також bahasa Indonesia/dienstmaleisch. Сьогодні ж, мабуть, мільйони молодих індонезійців з різних етнолінгвістичних середовищ говорять індонезійською як своєю рідною мовою.

Не відомо, чи через тридцять років не виросте покоління мозамбіканців, що говоритиме винятково мозамбікськопортугальською мовою. Проте зараз, наприкінці XX ст., справа полягає не в тому, чи поява такого покоління є sine quа поп для національної солідарності Мозамбіку. Перш за все, прогрес комунікаційних технологій, особливо радіо й телебачення, забезпечив друкарство союзниками, яких ще не існувало століття тому. Багатомовні радіотрансляції витворюють уявлені спільноти для неписьменних і для народностей 3 різноманітними рідними мовами. (Це дещо нагадує творення середньовічного християнського світу за допомогою візуальних репрезентацій і діяльності двомовних освічених осіб.) По-друге, націоналізми ХХ ст., як я вже говорив раніше, в основі своїй $є$ наслідуванням певних взірців. Вони базуються на майже двох сторіччях людського досвіду й трьох ранніх моделях націоналізму. Національні лідери,

\footnotetext{
була важливим i, можливо [sic], ключовим компонентом національної ідентичності. Навіть ті інтелектуали, яким легше було спілкуватися французькою, аніж рідною мовою, починали враховувати важливість того факту, що принаймні 85\% іхніх співвітчизників розмовляють тією самою мовою" (стор. 138). Вони вже добре усвідомлювали роль масової письменності у розвитку національних держав Європи та Японії. Але Марр демонструє, що протягом довгого часу не існувало чіткого взаємозв'язку між вибором мови й політичною позицією: “Підтримка рідної в'єтнамської мови не була чимось суттєво патріотичним, як і вживання французької не було ознакою колабораціоналізму" (стор. 150).
} 
таким чином, можуть свідомо запроваджузати цивільні й військові освітні системи, змодельовані з офріційних націоналізмів; застосовувати вибори, партійні організації й культурні заходи, запозичені з масових націоналізмів Свропи XIX ст., та підтримувати громадянсько-республіканську ідею, народжену на американському континенті. Крім того, сама ідея "нації" вже міцно закорінилася практично в усіх друкованих мовах; . а поняття національної приналежності стало, фактично, невід'ємною частиною політичної свідомості.

У світі, де національна держава є загальною нормою, все це означає, шо нації тепер можуть бути уявленими навіть $\mathrm{i}$ без мовної спорідненості - звичайно, не на наївному відчутті nosotros los Americanos, але на підставі загального усвідомлення можливостей, продемонстрованих новітньою історією ${ }^{41}$. У цьому зв'язку варто на завершення розділу повернутися до Європи й розглянути коротко ту націю, мовна різноманітність якої так часто використовувалася як дрючок для нападу на захисників лінгвістичних теорій націоналізму.

1891 року, під час нововведених ювілейних святкувань на відзначення 600-ї річниці Конфедерації Швіцу, Обвальдену й Нідвальдену, швейцарська влада “вирішила” визнати 1291 рік датою “заснування” Швейцарії ${ }^{42}$. Це рішення, якого довелось чекати 600 років, доводить, що швейцарський націоналізм $є$ новітнього, а не древнього походження. Справді, Хьюз твердить навіть, що ювілейні святкування 1891 року і стали народженням цього націоналізму, пояснюючи, що “в першій половині XIX ст.... освічені середні класи ще не надто переймалися проблемами національного існування: Мадам де Сталь [1766-1817], Фузелі [1741-1825], Анжеліка Кауффман [1741-1807], Сисмонді [1773-1842], Бенджамін Конс-

\footnotetext{
${ }^{41}$ Я кажу "можуть", тому що $\epsilon$, очевидно, безліч випадків, коли ця можливість відкидалась, або й далі відкидається. В таких випадках, як, скажімо, в Старому Пакистані, це пояснюється не етно-культурним ллюралізмом, а забороною паломництв.

${ }^{2}$ Christopher Hughes. Switzerland, p. 107. Цей чудовий текст, яким слуш1ю захоплювався Сетон-Вотсон, послужив основою наступних спостережень.
} 
тант [1767-1830], чи всі вони були швейцарцями?": Якщо очевидною відповіддю буде "навряд чи", ії значення підкреслюється тією обставиною, що за межами Швейцарії по всій Європі протягом першої половини ХІХ ст. виникали народномовні націоналістичні рухи, в яких головні ролі відігравали "освічені середні класи" (тобто, філологи й капіталісти). Чому ж тоді націоналізм так пізно прийшов до Швейцарії, та які наслідки мало це запізнення для ії остаточного формування (зокрема, для сучасного розмаїття "національних мов")?

Частково відповідь треб́ шукати в молодості швейцарської держави, сліди якої, за іронічним висловом Хьюза, важко знайти раніше від 1813-1815 років “без надуживання уявою,"44. Він нагадує нам, що перше по-справжньому швейцарське громадянство, введення прямого виборчого права (для чоловіків) і скасування "внутрішніх" зборів і митних зон стало заслугою Гельветичної республіки, примусово створеної внаслідок французької окупації 1798 року. Лише в 1803 році, після здобуття Тічино, до держави додалася значна кількість італомовних жителів. Щойно в 1815 році вона отримала густонаселені франкомовні кантони Валлісу, Женеви й Невшателю від анти-французького Священного Союзу - в обмін на нейтральний статус і вельми консервативну конституцію ${ }^{45}$. По суті, сьогоднішня багатомовна Швейцарія $€$ продуктом початку XIX ст.

Другим фактором була відсталість країни (яка, в поєднанні з їі складною топографією й браком придатних для

${ }^{43}$ Ibid., p. 218. Дати вставлені мною.

${ }^{44}$ Ibid., p. 85.

${ }^{45}$ Плюс Ааргау, Сен Гален і Грізонс. Останній кантон особливо цікавий тим, шо сьогодні лишається єдиною територією романшу, найбілыл швейцарської мови з усіх національних мов країни - статус якої вона, однак, отримала лише 1937 року! Ibid., pp. 59 and 85.

46 Можна мимохідь зазначити, шо Мадам де Сталь ледве встигла застати їі народження. Крім того, іï родина, як і сімейство Сисмонді, походила з Женеви, яка була незалежною від “ІІвейшарії” аж до 1815 року Не дивно, що швейцарська національність не надто обтяжувала їх. 


\section{ОСТАННЯ ХВИЛЯ}

розробки ресурсів, уберігала ії від поглиненшя потужнішими сусідами). Нині ми можемо не пам'ятати того, що перед Другою світовою війною Швейцарія була бідною, з удвічі нижчим від Англії рівнем життя, й до того ж здебільшого сільсъкою країною. В 1850 році ледве 6\% населення проживало в мінімально урбанізованих районах, а в 1920 році ця цифра зросла лише до $27,6 \%{ }^{\circ \prime}$. Отже, впродовж XIX ст. основу населення складало малорухливе селянство (коли не брати до уваги древнього промислу постачати відчайдушних юнаків іноземним арміям та папській гвардії). Відсталість країни була не тільки економічною, але й політичною та культурною. “Старою Швейцарією”, територія якої залишалася незмінною між 1515 і 1803 роками й більшість мешканців якої розмовляли тим чи іншим з численних німецьких діалектів, правила широка коаліція кантональних аристократичних олігархій. "Секрет витривалості Конфедерації полягав у її подвійній природі. Проти зовнішніх ворогів вона могла достатньою мірою об'єднати свої народи. Проти внутрішнього бунту вона могла достатньою мірою об'єднати свої олігархії. Якщо повставали селянни, що траплялося приблизно тричі кожного століття, про розбіжності забували, й уряди інших кантонів надавали своюдопомогу, часто, хоч і не завжди, підтримуючи в усьому своїх колег-гравителів" ${ }^{48}$. За винятком монархічних інституцій, картина ця не дуже відрізняється від численних дрібних князівств у межах Священної Римської імперії, з яких останнім реліктом залишається Ліхтенштейн на східному швейцарському кордоні ${ }^{*}$.

Показово, що навіть 1848 року, майже через два покоління після утворення швейцарської держави, давні релігійні розбіжності були політично більш значимими від мовних. На

${ }^{47}$ Ibid., pp. 173 and 274. Будь-який “культурний середній клас" дев'ятнадцятого сторіччя мав бути вельми нечисленним.

${ }^{48}$ Ibid., p. 86. Виділено нами.

49 Відсутність монархій була також характерною для Ганзейського союзу, широкої політичної коаліції, якій важко було б приписати державний чи національний статус. 


\section{УЯВЛЕНІ СПІЛЬНОТИ}

територіях, визначених як католицькі, протестантизм був поза законом, а в протестантських регіонах, відповідно, нелегальним був католицизм; і ці закони підлягали суворому виконанню. (Мова ж залишалася справою особистого вибору й зручності.) Лише після 1848 року, під впливом європейських революцій і загального поширення народномовних національних рухів, релігія поступилася своїм місцем мові, й країна виявилась розділеною на стало визначені лінгвістичні регіони. (Теперуже релігія стала справою особистого вибору)" .

Зрештою, живучість - у такій маленькій країні - великої кількості різних, часом взаємно незрозумілих німецьких діалектів, свідчила про те, що до більшої частини швейцарського селянського суспільства вельми пізно прийшли друкарський капіталізм і стандартизована сучасна освіта. Таким чином Hochsprache (друкована німецька) мала донедавна державномовний статус рівня ararisch deutsch та dienstmaleisch. Крім того, Хьюз зазначає, що нині "вищі" посадовці повинні володіти практичним знанням двох федеральних мов, припускаючи тим самим, шо від їхніх підлеглих не вимагається подібної компетентності. Непрямим чином подібна точка зору підкреслюється і в Федеральній Директиві 1950 року, яка стверджує, що “освічені німецькомовні швейцарці, безперечно, здатні працювати з французькою мовою, як і освічені італомовні швейцарці" тут маємо ситуацію не надто, по суті, відмінну від мозамбікської - двомовний політичний клас, зручно влаштований серед багатьох одномовних народностей, з тією лиш різницею, шо "другою мовою" є мова могутнього сусіда, а не минулого колоніального володаря.

Однак, якщо взяти до уваги той факт, що в 1910 році рідною мовою майже $73 \%$ населення була німецька, $22 \%$ французька, 4\% італійська, а 1\% романш (ці пропорції залишалися майже незмінними протягом минулих десятиріч), мабуть, дивним виглядає, шо в другій половині XIX ст. -

\footnotetext{
${ }^{50}$ Ibid., p. 274.

${ }^{51}$ Ibid., pp. 59-60. Виділено нами.
} 
добі офіційних націоналізмів - не виникало жодних спроб онімечування. Безперечно, що до самого 1914 року існували сильні пронімецькі симпатії. Кордони між Німеччиною й німецькою Швейцарією були абсолютно прозорі. Торгівля й інвестиції, аристократи й професіонали, все це переміщалося в обидва боки з цілковитою свободою. Але Швейцарія також межувала з двома іншими головними європейськими державами, Францією й Італією, а тут політичний ризик онімечування був надто явним. Легальний паритет між Німеччиною, Францією й Італією був, таким чином, зворотною стороною медалі швейцарського нейтралітету ${ }^{2}$.

Всі попередні міркування переконують, що швейцарський націоналізм можна зрозуміти лише як частину "останньої хвилі”. Якщо Хьюз правий, датуючи його народження 1891 роком, то він усього лише десятьма роками старший від бірманського чи індонезійського націоналізмів. Інакше кажучи, він виник у ту добу світової історії, коли нація перетворювалась у міжнародну норму й коли ставало можливим "моделювати" національну приналежність у значно складніший спосіб, ніж досі. Якщо політичний консерватизм і соціальноекономічна відсталість Швейцарії “затримали” виникнення

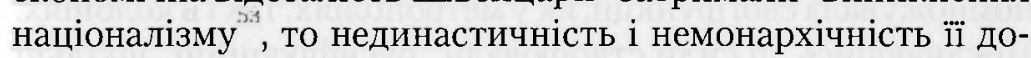
модерних полігичних інституцій допомогли запобігти ексцесам офіційного націоналізму (на відміну від випадку Сіаму, який ми розглянули в VII розділі). Зрештою, як і в випадку країн Південної Азії, виникнення швейцарського націоналізму напередодні комунікаційної революції XX ст. зробило можливим уявлення спільноти в спосіб, що не вимагав мовної однорідності.

\footnotetext{
${ }^{52}$ Зрівняння в правах романш в 1937 році навряд чи могло порушити пропорції.

${ }_{53}$ Соціальна структура У горшини також була відсталою, але мадярські аристократи перебували всередині величезної поліетнічної династичної імперії, в якій іхня уявна мовна група належала до звичайної меншини, хоча й дуже важливої. Невеличка республіканська аристократична олігархія Швейцарії ніколи не відчувала подібної загрози.
} 


\section{УЯВЛЕНІ СІІЛЬНОТИ}

На завершення, мабуть, варто було бще раз сформулювати головний аргумент цього розділу. "Остання хвиля" націоналізмів, здебільшого на колоніальних територіях Азії й Африки, була за своїм походженням відповіддю на глобальний імперіалізм нового типу, що виник завдяки досягненням промислового капіталізму. За неповторним визначенням Маркса: “Потреба постійного зростання ринку задля збуту своїх товарів жене буржуазію по цілій планеті" ${ }^{54}$. Але капіталізм також, немалою мірою завдяки поширенню ним друку, сприяв утворенню масових народномовних націоналізмів у Європі, які різною мірою підважували одвічний династичний устрій і підштовхували до самонатуралізації кожну схильну до того династію. Офіційний націоналізм сплав нового національного і старого династичного принципів (Британська імперія) - привів у свою чергу до того, що можна для зручності назвати "русифікацією" позаєвропейських колоній. Ця ідеологічна тенденція точно відповідала практичним потребам. Імперії кінця XIX ст. були надто великі й надто розкидані, щоб ними могла правити жменька осіб. Крім того, держава, в упряжі з капіталізмом, стрімко помножувала свої функції, як у метрополіях, так і в колоніях. Поєднавшись, ці сили створювали “русифікаційні” шкільні системи, спрямовані частинно на підготовку другорядних кадрів для державної й корпоративної бюрократії. Ці шкільні системи, централізовані й стандартизовані, породжували нові маршрути паломництв, де Римом ставали різні колоніальні столиці, адже нації, приховані в глибині імперій, перешкоджали просуванню до центру. Звичайно, хоча й не завжди, ці освітні паломництва мали свій відповідник у шляхах адміністративної кар'єри. Перетинання освітніх й адміністративних паломництв створювало територіальну підставу для нових “уявлених спільнот”, в яких місцеві мешканці могли себе усвідомлювати "громадянами нації".

${ }^{54}$ Marx and Engels. The Communist Manifesto, p. 37. Хто, крім Маркса, міг би назвати "переслідуваним" клас, що змінював світ? 
Розвиток колоніальної держави, яка, так би мовити, запрошувала "тубільців" до шкіл та офісів, і колоніального капіталізму, котрий не допускав їх далі приймальних, означав, що першими головними речниками колоніального націоналізму переважно ставали самотні двомовні інтелігенти, не пов'язані з енергійною місцевою буржуазією.

Однак, як інтелігенція двомовна, і перш за все, як інтелігенція початку XX ст., вони мали доступ, у своїх шкільних аудиторіях і поза ними, до моделей нації, національності й націоналізму, утворених бурхливим і хаотичним досвідом більш ніж вікової американської та європейської історії. Ці моделі, своєю чергою, допомагали оформлюватися тисячам неясних мрій. Уроки креольського, лінгвістичного й офіційного націоналізмів у різних комбінаціях наслідувалися, пристосовувалися й вдосконалювалися. Зрештою, тим часом, як капіталізм усе стрімкіше трансформував засоби фізичної й інтелектуальної комунікації, інтелігенція знаходила способи оминати друк і поширювати уявлену спільноту не тільки серед неписьменних мас, але й навіть серед освічених людей, котрі читають різними мовами. 


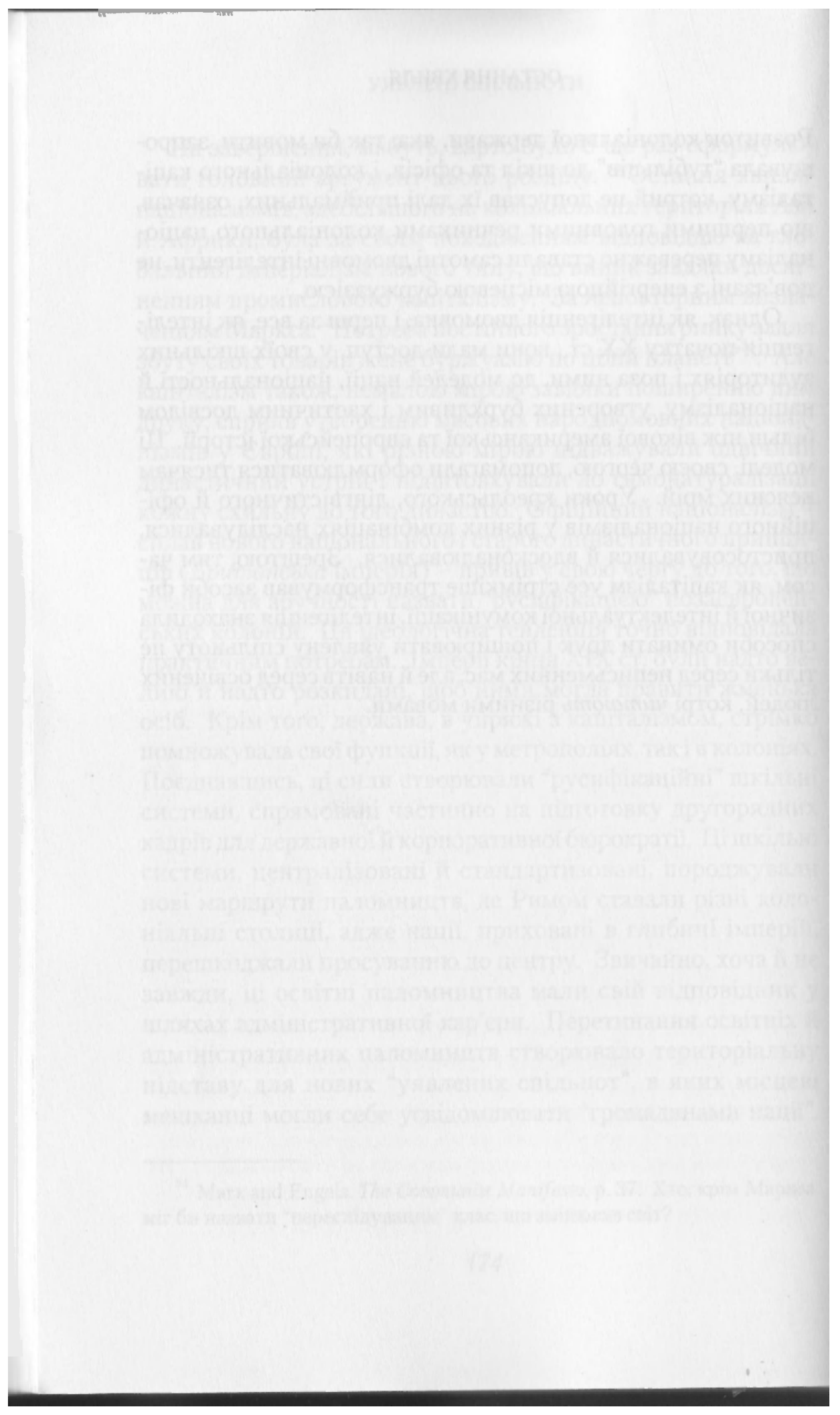




\section{Патріотизм і расизм}

У попередніх розділах я намагався окреслити процеси, завдяки яким націю стали виображати, а згодом моделювати, адаптувати й трансформувати. Такий аналіз неминуче торкався головним чином соціальних змін і різних форм свідомості. Сумнівно втім, шоб одними тільки соціальними змінами або змінами у свідомості можна було б пояснити ту відданість, з якою люди ставляться до витворів своєї уяви :бо, нагадуючи питання, поставлене на початку цієї праці 'юму люди готові померти заради цих витворів.

В епоху, коли прогресивні інтелектуали-космополіти

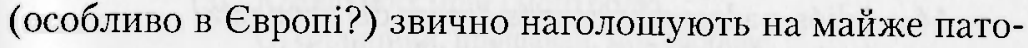
логічному характері націоналізму, на тому, що він живиться страхом і ненавистю до Іншого, й на його спорідненості з расизмом ${ }^{1}$ варто було б нагадати собі, шо нації викликають любов, причому нерідко любов глибоко жертовну. Культурні продукти націоналізму - поезія, художня проза, музика, образотворче мистецтво - дуже виразно виявляє цю любов

\footnotetext{
' Порівняймо наведений раніше уривок з “Розпаду Британії" Нейрна, crop. 14-15, і дещо бідермайєрівське судження Хобсбоума: "Основопопюжним фактом [є те], що справжні марксисти не $є$ націоналістами". "Some Reflections", p. 10.
} 
у тисячах різноманітних форм і стилів. 3 іншого боку, наскільки рідкісними є аналогічні зразки націоналістичної продукції, що виражали б страх і ненависть?. Навіть якщо взяти колонізовані народи, які мали всі підстави для того, щоб зненавидіти своїх імперіалістичних володарів, дивовижно, наскільки незначний елемент ненависті у цих проявах національного почуття. Ось, наприклад, перша й останні строфи з "Último Adiós", відомої поеми, написаної Рісалем в очікуванні страти, до якої його засудив іспанський імперіалізм ${ }^{3}$ :

1. Adiós, Patria adorada, region del sol querida, Perla del Mar de Oriente, nuestro perdido eden, A darte voy, alegre, la triste mustia vida; $\mathrm{Y}$ fuera mas brillante, mas fresca, mas florida, Tambien por ti la diera, la diera por tu bien...

12. Entonces nada importa me pongas en olvido: Tu atmosfera, tu espacio, tus valles cruzare; Vibrante y limpia nota sere par tu oido; Aroma, luz, colores, rumor, canto, gemido, Constante repitiendo la esencia de mi fe.

13. Mi Patria idolotrada, dolor de mis dolores, Querida Filipinas, oye el postrer adiós.

Ahí, te dejo todo: mis padres, mis amores. Voy donde no hay esclavos, verdugos ni opresores; Donde la fe no mata, donde el que reina es Dios.

14. Adiós, padres y hermanos, trozos del alma mía, Amigos le la infancia, en el perdido hogar; Dad gracias, que descanso del fatigoso día; Adiós, dulce extranjera, mi amiga, mi alegría; Adiós, querido seres. Moris es descansar.

\footnotetext{
${ }^{2}$ Чи зуміли 6 ви відразу пригадати хоча б три Оди Ненависті? Друга строфа державного гімну "Боже, борони Королеву/Короля" звучить вельми показово: "Господи наш Боже, встань,/ Розжени іiі/його ворогів,/ Нехай поляжуть вони;/ Зруйнуй їхні плани,/ Розгадай підступні хитрощі;/ До Тебе звертаємо наші надії;/ Боже, борони нас усіх". Зауважмо, по ці вороги не мають жодної ідентичності й могли б бути як англійцями, такі
} 
Зауважте, що не тільки не згадано національність "тиранів", але й палкий патріотизм Рісаля чудово передано "їхньою" мовою .

Деякою мірою природу політичної любові можна зрозуміти, якщо розглянути, яким чином змальовується різними мовами об'єкт цієї любові: йдеться або про спорідненість (вітчизна, Vaterland, patria), або про поняття, пов'язані з домом (heimat чи tanah air [земля й вода, фраза, якою корінні мешканці визначають індонезійський архіпелаг]). Обидві ідіоми виражають те, з чим людина природно пов'язана. Як

будь-ким іншим, оскільки є “ї/його” ворогами, а не “нашими”. Весь цей гімн $є$ пеаном монархії, а не нації - яку навіть не згадано.

3 Jaime C. de Veyra. El "Último Adios" de Rizal: estudio crítico-expositıvo, pp. 89-90 and 101-102 (переклад).

1. Прощавай, рідна земле, сонцем омита,

Перлина Східного моря, втрачений раю,

Тобі я радо віддаю своє сумне життя;

Було б воно квітучішим, свіжішим,

Віддав би теж його тобі на благо.

12. Що з того, що забула ти мене,

Коли я бачу твої простори, долини;

Будь, наче нота, чиста і дзвінка;

Будь світлом, пахощами, піснею й плачем,

Будь вірою моєю назавжди.

13. Країно моїх мрій і мого болю,

О, Філіппіни, прощавай, моя любове.

Всі прошавайте, друзі та батьки.

Я йду туди, де ні тиранів, ні рабів;

Де віра не вбиває, де царює Бог.

14. Востаннє я з родиною прощаюсь,

3 дитинства друзями, із хатою своєю;

Гіркому дню моєму вже надходить край;

Всі прощавайте, близькі й незнайомі;

Настав мій час. Спочинком стане смерть.

${ }^{4}$ Поема, однак, була швидко перекладена на тагалозьку мову видатним філіппінським революціонером Андресом Боніфаціо. Його версію можна знайти в: ibid., pp. 107-109. 
ми вже пересвідчилися раніше, в усьому “природному" завжди $\epsilon$ щось таке, що не підлягає вибору. Таким чином, національна приналежність уподібнюється до кольору шкіри, статі, родоводу й часу народження - тобто, до тих речей, які неможливо змінити. I в цих “природних зв'язках" людина віднаходить те, що можна назвати "красою gemeinschaft". Інакше кажучи, саме тому, що ці зв'язки неможливо обрати, вони й оповиті ореолом безкорисливості.

Хоча протягом останніх двох десятиріч багато писалося про ідею родини як виразу структури влади, така концепція залишається чужою для абсолютної більшості людства. Адже родина традиційно мислилася сферою безкорисливої любові й єдності. Тому, якщо історики, дипломати, політики й соціологи легко оперують категорією "національних інтересів", для більшості простих людей з будь-яких верств суть нації полягає якраз у відсутності подібних “інтересів", тобто в безкорисливості. Саме тому вона й може вимагати жертв.

Як зазначалося раніше, великі війни цього століття виняткові не стільки тому, що вони дозволили людям убивати в безпрецедентних масштабах, скільки колосальним числом тих, хто 3 переконання жертвував своїм життям. Чи не очевидно, що кількість убитих значно переважає кількість тих, хто убивав? Ідея найвищої пожертви, якої вимагає доля, існує лише в парі з ідеєю очищення.

Вмираючи за свою країну, яку здебільшого не вибирають, людина набуває моральної величі, незрівнянної зі смертю заради лейбористської партії, американської медичної асоціації чи навіть "Міжнародної амністії", адже до всіх цих організацій можна вступити й вийти з власної волі. Загибель за революцію також черпає свою велич з того, що вважається чимось фундаментально чистим. (Якби люди уявляли пролетаріат лише як групу, зацікавлену гонитвою за холодильниками, відпустками або владою, чи прагнули б вони, включно з самими пролетарями, вмирати за нього?") За іро-

\footnotetext{
${ }^{5}$ Це формулювання не означає, ніби революційні рухи не переслідують матеріальні цілі. Але цілі ці уявляються не накопиченням індивідуальних надбань, а як умови для вимріяного Руссо загального bonheur.
} 


\section{ПАТРІОТИЗМ I РАСИЗМ}

нією долі, тією мірою, якою марксистські інтерпретації історії мисляться (а не раціонально пізнаються) як вияв неминучої необхідності, вони також набувають аури чистоти i безкорисливості.

Та вернімося ще раз до мови. По-перше, відзначимо споконвічність мов, навіть тих, що вважаються сучасними. Нiхто не може назвати дату народження будь-якої з мов. Кожна виринає непомітно з неозорого минулого. (Оскільки hото sapiens $€$ homo dicens, досить важко уявити, щоб мова була молодшою за людство.) Таким чином, коріння мов, схоже, сягає глибше від чого-небудь іншого в сучасних суспільствах. Водночас, ніщо емоційніше від мови не пов'язує нас із померлими. Коли англомовні люди чують слова “Земля до землі, прах до праху, пил до пилу" - вперше сказані майже чотири 3 половиною століття тому - іх охоплює примарне відчуття спільності в однорідному порожньому часі. Вагомість цих слів лише частково зумовлена їх формальним смислом; вона походить також, так би мовити, від спадкової "англійськості".

По-друге, існує особливий тип одночасної спільності, яку творить лише тільки мова - перш за все в поетичній та пісенній формах. Візьмімо, приміром, національний гімн, що виконується під час національних свят. Якими б банальними не були його слова, якою б невиразною не була мелодія, цей спів пробуджує відчуття спільності. Саме в такі миті абсолютно незнайомі люди вимовляють ті самі рядки під ту саму мелодію. Виникає образ унісону, злагоди . Співання "Марсельєзи", "Вальсуючої Матільди" та “Індонезії Райя" створює нагоду для унісонності, для резонуючої фізичної реалізації уявленої спільноти. (Подібне відбувається, коли слухаєп [й повторюєш, можливо, тихенько] декламування обрядової поезії, такої як розділи з "The Book of Common Prayer" Якою самовідданістю повниться такий унісон! Хоча ми й

\footnotetext{
${ }^{6}$ Порівняймо цей хор a capella 3 повсякденною мовою, яка типово нагадує, так би мовити, спів декана й кантора, тобто є формою діалогу й обміну думками.
}

Англіканський молитовник. 


\section{УЯВЛЕНІ СІІЛЬНОТИ}

усвідомлюємо, що інші співають ці пісні в ту саму мить і так само, як ми, проте не маємо жодного поняття, хто вони, i навіть де, за межами нашої чутності, вони співають. Нас нішо не єднає, крім звуків в уяві.

Утім, до подібних хорів можна з часом долучитися. Хоч я й латиш, моя донька може бути австралійкою. Син італійського іммігранта в Нью-Йорку віднайде предків серед перших англійських колоністів. Навіть якшо національність неуникненна, ця неуникненність коріниться в історії. Показовим $є$ указ Сан Мартіна про перехрещування кечуамовних індіанців у "перуанців" - акт, що нагадує релігійне навертання. Він демонструє, що від початку основою нації мислилася мова, а не кров, і що до уявленої спільноти можна було "запросити". Отже сьогодні навіть найбільш ізольовані нації визнають принцип натуралізащіі (яке чудове слово!), незалежно від того, якою складною не була $б$ процедура на практиці.

Сприймаючись і як історична невідворотність, і як колектив, уявлений через мову, нація постає відкритою й закритою водночас. Цей парадокс добре ілюструють мінливі ритми відомих рядків, присвячених загибелі Джона Мура в битві за Корунью :

1. Not a drum was heard, not a funeral note, As his corse to the rampart we hurried;

Not a soldier discharged his farewell shot O'er the grave where our hero we buried.

2. We buried him darkly at dead of night, The sods with our bayonets turning; By the struggling moonbeams' misty light, And the lantern dimly burning.

3. No useless coffin enclosed his breast, Not in sheet or in shroud we wound him;

But he lay like a warrior taking his rest, With his martial cloak around him...

5. We thought, as we hollowed his narrow bed, And smoothed down his lonely pillow, 


\section{ПАТРІОТИЗМ І РАСИЗМ}

That the foe and the stranger woukl tread o'er his head And we far away on the billow...

8. Slowly and sadly we laid him down.

From the field of his fame fresh and gory;

We carved not a line, and we raised not a stone -

But we left him alone with his glory!

Ці рядки оспівують пам'ять полеглого героя з невіддільною від самої англійської мови довершеністю, непідвладною перекладу, доступною слуху лише її носіїв. А проте і Мур, i його панегірист були ірландцями. I немає причини, щоб який-небудь нащадок французьких чи іспанських "ворогів" Мура не зміг повністю відчути резонанс поеми: англійська мова, як і будь-яка інша, завжди відкрита новим слухачам, читачам і співрозмовникам.

7 "The Burial of Sir John Moore", in The Poems of Charles Wolfe, pp. 1-2.

1. Не було ані бубнів, ні дзвонів сумних, Коли труп його несли до валу;

Над могилою жоден солдат не стріляв, Де ми свого героя ховали.

2. Ми його поховали у тиші нічній, Розривали багнетами землю; Місяць тьмяно освітлював нас ізгори I ліхтар палахтів непевно.

3. Не було ні труни, де покласти його, Ані савану, шоб загорнути;

Він лежав, як солдат, шо спочити захтів, Бойовий плаш вкривав йому груди...

5. Ми гадали, готуючи ложе вузьке, Цю самотню могилу у полі,

Як топтатимуть тіло йому вороги, А ми будем далеко у морі.

8. Ми врочисто поклали його до землі, Де точилася битва кривава;

Не лишили надгробного каменя ми Але $з$ ним залишилася слава! 


\section{УЯВЛЕНІ СІІЛІНОТИ}

Прислухаємось до Томаса Брауна, який зумів кількома реченнями охопити цілу людську історію:

Навіть устремління древніх честолюбців мали перевагу над нашими, бо розпочавши рано і ще до ймовірного полудня історії, древні герої вже мали за собою великі звершення великих планів, завдяки яким переживуть власні пам'ятники і механічні витвори. Але в цьому останньому акті історії не варто очікувати, що пам'ять про нас збережуть подібні мумії, коли устремління никнуть перед страхом пророцтва Ілії, а Карла V від Гектора відділятиме два Мафусаїлові життя.

Стародавні Єгипет, Греція й Юдея переплітаються тут зі Священною Римською імперією, але іх об'єднання крізь тисячі років і тисячі миль досягається стилем Браунової англійської прози XVII ст." Цей уривок, хоча й не без труднощів, надається перекладу. Але від моторошної величі всіх цих "probable Meridian of time", "Mechanicall preservations", "such Mummies unto our memories" та "two Methusela's of Hector" мурашки бігтимуть лише по спинах англомовних читачів.

На цій сторінці фрагмент відкривається читачеві. 3 іншого боку, не менш моторошна велич останніх рядків "Yang Sudah Hilang” видатного індонезійського автора Прамоедьї Ананти Тоера":

Suara itu hanya terdengar beberapa detik saja dalam hidup.

Getarannya sebentar berdengung, takkan terulangi lagi. Tapi seperti juga halnya dengan kali Lusi yang abadi menggarisi kota Blora, dan seperti kali itu juga, suara yang tersimpan menggarisi kenangan dan ingatan itu mengalir juga - mengalir kemuaranya, kelaut yang tak bertepi. Dan tak seorangpun tahu kapan laut itu akan kering dan berhenti berdeburan.

\footnotetext{
${ }^{8}$ Hydriotaphia, Ume-Burial, or; A Discourse of the Sepulchrall Umes lately found in Norfolk, pp. 72-73. ІЦодо "імовірного полудня історії", порівняйте з єпископом Отто Фрейзінгенським.

9 Проте згадки про "Англію", власне, немає. Це чимсь нагадує ті провінційні газети, які, завдяки іспанській мові, приносили увесь світ до Каракасу і Боготи.

Tjerita dan Blora [Оповідання від Блори], pp. 15-44, at p. 44.
} 
Hilang.

Semua itu sudah hilang dari jangkauan panc[h]a-indera.

виявиться, найімовірніше, закритою на тій самій друкованій сторінці ${ }^{*}$.

Кожною мовою можна оволодіти, але на це треба пожертвувати частку життя: кожна нова перемога вимірюється днями, що залишились до смерті. Доступ до інших мов обмежує не їх непроникність, але смертність людини. Звідси й певна інтимність усіх мов. Французькі й американські імперіалісти правили, експлуатуючи й убиваючи в'єтнамців десятиліттями. Проте, що б вони не виробляли, в'єтнамська мова лишалася неушкодженою. Відповідно, часто виникало роздратування від в'єтнамської “непроникності" й той похмурий розпач, що породжував злостивий жаргон занепадаючого колоніалізму: "gooks", "ratons" і т.д." (В кінцевому підсумку, єдиною відповіддю на інтимність мови пригноблених $є$ або відступ, або нова різня.)

Подібні епітети, за своєю внутрішньою формою безумовно расистські, й аналіз цієї форми продемонструє, в чому полягає суттєва помилка Нейрна, коли він доводить, що расизм і антисемітизм походять від націоналізму - i отже “фашизм, досліджений в усій своїй історичній глибині, може нам розказати про націоналізм більше від будь-якого іншого епізоду історії" . Скажімо, таке слово, як "slant" (косий), що $€$ скороченням від “slant-eyed” (косоокий), виражає не просто звичайну політичну неприязнь. Воно відкидає національну приналежність, зводячи характеристику супротивника до фізіологічного типу його обличчя ${ }^{4}$. Воно заперечує слово

\footnotetext{
${ }^{11}$ Але вслухайтесь у ці рядки! Я дещо змінив оригінальну орфографію у відповідності з теперішніми правилами, шоб зробити цитату фонетично максимально близькою до вимови.

Логіка тут така: 1. Я помру, перш ніж проникну до них. 2. Я маю таку силу, шо вони змушені вивчати мою мову. 3. Але це означає, шо вони порушать мою приватність. Називаючи їх “чурками”, я хоч трохи помшуся за це.

The Break-up of Britain, pp. 337 and 347.

Зауважмо, шо не існує жодного явного, усвідомленого антоніму до назвиська "slant". "Круглий”? "Прямий”? “Овальний"?
} 
“в'єтнамець”, підміняючи його собою; як і raton, підміняючи “алжирця", заперечує його. Водночас воно жбурляє "в'єтнамця" до безіменної юрби разом із "корейцями”, “китайцями”, “філіппінцями” тощо. Характер подібних слововитворів стає ще очевиднішим, якщо їх порівняти з іншими назвами періоду В'єтнамської війни, такими як "Charlie" й "V.C.[Viet Cong]”, або з давнішої епохи: “фрици”, “гуни", “япошки” і “жаби”, кожний з яких стосувався лише однієї окремої національності, тим самим визнаючи з ненавистіо за противником членство в лізі націй ${ }^{i .}$.

Націоналізм мислить в категоріях історичної долі і призначення, расизм же маячить про одвічну порчу, споконвіку передавану шляхом безконечних мерзенних спаровувань, i все це поза історісю. Негри, завдяки невидимому чорному пензлю, залишаються назавжди неграми; євреї, Авраамове сім'я, навічно євреями, які 6 паспорти не мали та якими 6 мовами не володіли. (Так для нацистів німці єврейсъкого походження зажди були самозванцями ${ }^{16}$.)

Фантазії расизму мають своє коріння, насправді, в класовій, а не національній ідеології: перш за все у претензіях правителів на божественність, а аристократів на "блакитну" чи "білу" кров і “породу"”. Не дивно отже, що батьком

${ }^{15}$ Втім, не лише в давнішу епоху. Тим не менше, нафталіном віддає від слів Дебре: “Я не бачу для Європи жодної надії, крім якпід гегемонією революційної Франції, що міцно утримує прапор незалежності. Іноді мені здається, що вся ця “анти-бошівська" міфологія й наш секулярний антагонізм до Німеччини можуть одного дня виявитися незамінними для порятунку революції або й навіть нашої національно-демократичної спадшцини". "Marxism and the National Question”, p. 41.

${ }^{16}$ Смисл виникнення сіонізму й народження Ізраїлю полягає в тому, що перший ознаменовував переосмислення древньої релігійної спільноти як нації, натомість другий алхімічне перетворення побожного мандрівника в місцевого патріота.

17 "Концепції вродженої вищості правлячого класу й увага до статусу успадковані ХX ст. від земельної аристократії. Живлячись новими джерелами, ці концепції згодом були звульгаризовані [sic] й стали привабливими для німецького народу в цілому як доктрини расової вищості". Barrington Moore, Jr. Social Origins of Dictatorship and Democracy, p. 436. 


\section{ПАТРІОТИЗМ I РАСИЗМ}

модерного расизму мав стати не якийсь дрібнобуржуазний націоналіст, а Жозеф-Артюр, граф де Гобіно ${ }^{18}$. Не дивно також, що расизм і антисемітизм, як правило, не перетинає міжнародних кордонів, обмежуючись національними межами. Інакше кажучи, вони виправдовують не стільки війни, скільки внутрішні репресії й панування ${ }^{19}$.

Позаєвропейський расизм XIX ст. завжди був пов'язаний з європейським пануванням, причому з двох досить близьких причин. Найголовнішою з них було зростання офіційного націоналізму й колоніальної “русифікації”. Як неодноразово підкреслювалось вище, офіційний націоналізм був типовою відповіддю загрожених династичних і аристократичних верств - вищих класів - на масовий народномовний націоналізм. Колоніальний расизм був основним елементом тієї концепції “імперії”, що намагалася з'єднати династичну легітимність із національною спільнотою. Задля цього принцип природженої, спадкової вищості, на який (хоч як хитко) спиралася її позиція, поширювався на безмежні заморські володіння, завуальовано (або й ні) припускаючи, що навіть коли, скажімо, англійські лорди від народження й вищі від інших англійців, то ті самі інші англійці своєю чергою вищі від підлеглих їм тубільців. Можна навіть твердити, що існування останніх колоніальних імперій підпирало домашні бастіони аристократії, оскільки ніби підтверджувало на глобальній сучасній арені архаїчні концепції влади й привілеїв.

${ }^{18}$ Дати цілковито підтверджують це. Гобіно народився 1816 року, через два роки після реставрації Бурбонів на французькому троні. Його дипломатична кар'єра, з 1848 по 1877 роки, розквітала протягом Другої імперії Луї Наполеона й реакційного монархічного режиму Марі Едме Патріс Моріса, графа де Макмагона, колишнього імперського проконсула Алжиру. Його "Essai sur l'Inegalite des Races Humaines" з'явилися 1854 року - чи не у відповідь на масові народномовно-націоналістичні заворушення 1848 року?

${ }^{19}$ Південноафриканський расизм часів Форстера і Боти підтримував дружні стосунки (хоча й вельми обережні) з видатними чорними політиками деяких незалежних африканських держав. Навіть якшо євреї й зазнавали дискримінації в Радянському Союзі, це не впливало на шанобливі робочі відносини Брежнєва з Кіссінджером. 


\section{УЯВЛЕНІ СНІЛЬНОТИ}

Певний успіх досягався - і в цьому полягає друга причина - тим, що колоніальна імперія, з її стрімко зростаючим бюрократичним апаратом та "русифікаторською" політикою, давала змогу значній кількості буржуазії й обивателів грати роль аристократії будь-де в межах імперії, тільки не вдома. В кожній колонії можна було побачити цю сумну й комічну tableau vivant. міщанин у дворянстві декламує поезію на фоні особняків і парків з мімозами й бугенвіліями, а навколо велика масовка зі слуг, конюхів, садівників, кухарів, покоївок, служниць, прачок i, що найважливіше, коней ${ }^{20}$. Навіть ті, хто не міг дозволити собі подібний стиль, наприклад, молоді холостяки, все-таки втішалися сумнівним статусом французького вельможі напередодні жакерії :

У Мулмейні, що в нижній Бірмі [це непримітне місто потребує роз'яснень для читачів з метрополіі], мене ненавиділа величезна кількість людей - вперше в житті я був достатньо важливою особою, щоб подібне могло зі мною статися. Я служив у поліцейському підрозділі міста.

Ця “тропічна готика" стала можливою завдяки надзвичайній силі, якою розвинений капіталізм наділив метрополію - силі настільки великій, що ії можна було тримати, так би мовити, за лаштунками. Ніщо не ілюструє капіталізм у феодально-аристократичному платті краще від колоніальноі вояччини, з її сумнозвісними відмінностями від підрозділів метрополії, навіть суто інституційними ${ }^{22}$. Таким чином, у Європі мали "Першу армію", набрану з жителів метрополіі на основі масового, загальногромадянського призиву. Вона ідеологічно мислилась як захисник heimat, батьківщини;

${ }^{20}$ Вражаючу колекцію фотографій таких tableaux vivants у Голландській Індії (та елегантно іронічних текстів) див.: "E. Breton de Nijs", Tempo Doeloe.

${ }^{21}$ George Orwell. "Shooting an Elephant", in The Orwell Reader, p. 3. Слова в квадратних дужках вставлені, зрозуміло, мною.

${ }^{22}$ KNIL (Koninklijk Nederlandsch-Indisch Leger) був досить відокремлений від KL (Koninklijk Leger) у Голландії. Legion Etrangere майже віл початку був легально усунений від операцій у континентальній Франци. 


\section{ПАТРІОТИЗМ I РАСИЗМ}

була екіпірована практичною, утилітарною формою-хакі, озброєна найновішими видами зброї. У мирний час розквартирована в казармах, під час війни займала місця у траншеях або в обслузі польових гармат. Поза Європою мали "Другу армію”, навербовану (за винятком офіцерів) з найманців, котрі походили з місцевих релігійних та етнічних меншин. Ідеологічно вона замислювалася як поліцейська сила; в мундирах, призначених для підкорення сердець в ліжку чи бальному залі; озброєна шаблями та технологічно застарілою збросю; в мирний час парадувала, а під час війни гарцювала верхи на конях. Якщо Генеральний штаб Пруссії, цей військовий наставник Європи, наголошував на анонімній взаємозлагодженості професійних військ, артилерії, залізничному транспорті, інженерних спорудах, стратегічному плануванні тощо, то колоніальна армія віддавала перевагу славі, еполетам, особистому героїзму, грі в поло й архаїчній випуканості манер у стосунках між офіцерами. (Вона могла собі це дозволити, бо десь там на задньому плані знаходилася Перша армія і флот.) Така ментальність протривала досить довго. Льоте писав у Тонкіні 1894 року ${ }^{22}$ :

Quel dommage de n'etre pas venu ici dix ans plus tôt! Quelles carrieres a y fonder et a y mener. Il n'y a pas ici un de ces petites lieutenants, chefs de poste et de reconnaissance, qui ne developpe en 6 mois plus d'initiative, de volonte, d'endurance, de personnalité, qu'un officier de France en toute sa carriere.

1951 року в Тонкіні Жан де Латтр де Тасіньї, “якому подобались офіцери, що поєднували відвагу й “стиль”, відразу ж захопився жвавим кавалеристом [полковником де Кастрі] в

23 “Яка ганьба, шо я не прибув на десять років раніше! Яких кар’єр тут можна досягти! Тут немає жодного лейтенантика, поштового службовця чи прапівника розвідки, який би протягом 6-ти місяців не виявив більше ініціативи, волі, витривалості, iндивідуальності, ніж будь-який французький офіцер упродовж цілої своєї кар'ери".

Lyautey. Lettres du Tonkin et de Madagascar.(1894-1899), р. 84. Лист від 22 грудня 1894 року з Гани. Виділено нами. 
червоній фесці, яку носять спагі, й кашне, з розкішним стеком та поєднанням невимушених манер з князівською осанкою, що зачаровували жінок в Індокитаї 1950 -х років не менш ніж парижанок у $1930-\mathrm{x}^{\prime \prime \prime}$.

Іншою повчальною рисою аристократичного або псевдоаристократичного походження колоніального расизму була типова "солідарність білих" між колоніальними правителями різних національних метрополій, яка 6 конкуренція і конфлікти не розділяли іх. Ця своєрідна понаддержавна солідарність одразу нагадує нам про класову солідарність європейських аристократій XIX ст., налагоджувану в мисливських будиночках, на курортах і балах; а також про те братерство "офіцерів і джентльменів", відповідно до гуменного духу XX ст. закріплене у Женевській конвенції, що гарантує, на відміну від партизан і цивільних, привілейоване ставлення до захоплених у полон ворожих офіщерів.

${ }^{24}$ Bernard B. Fall. Hell is a Very Small Place: The siege of Dien Bien Phu p. 56. Клаузевіц, мабуть, перевернувся би в труні. [Спагі, що походять, як і сипаї, від османських сипагі, були кавалеристами-найманцями нерегулярної "Другої армії" в Алжирі]. Це правда, що Франція Льоте й де Латтра була республіканською Францією. Одначе, зазвичай балакуча Grande Muette перетворилась на початку Третьої Республіки в притулок для аристократів, яких усе частіше усували від влади з усіх інших поважних закладів громадського життя. В 1898 році четверта частина всіх бригадних генералів та генерал-майорів складалася з аристократів. Білые того, цей опанований аристократами офіцерський корпус відіграв вирішальну роль у становленні французького імперіалізму XIX и XX ст. "Суворий контроль, під яким перебувала армія в metropole, ніколи повністю не розповсюджувався на la France d'outre-mer. Розширення Французької імперії в XIX ст. відбувалося частково завдяки власній ініціативі колоніальних військових командирів. Франшузька Західна Африка, цей великою мірою витвір генерала Фейдерба, й також Французьке Конго збільшувалися в основному за рахунок самостійних набігів углиб континенту. Військові офіцери несли також відповідальність за faits accom plis, які призвели до встановлення 1842 року французького протекторату на Таїті та, меншою мірою, до окупації французами індокитайського Тонкіну в 1880-х роках... 1897 року Гальєні без зайвих зволікань скасував на Мадагаскарі монархію й депортував королеву без жодних консультацій з французьким урядом, який пізніше змирився з fait accompli..." John S. Ambler. The French Army in politics, 1945-1962, pp. 10-11 and 22. 


\section{ПАТРІОТИЗМ І РАСИЗМ}

Наведене вище твердження справедливе й щодо колоніальних народів. Адже, абстрагуючись від заяв деяких колоніальних ідеологів, просто дивовижно, наскільки невиразно в антиколоніальних рухах артикульовано таке сумнівне явище, як "зворотний расизм". Мова тут легко може ввести в оману. Скажімо, яванське слово londo (що походить від Hollander або Nederlander) означало, в певному сенсі, не тільки "голландці", але й “білі”. Проте вже саме походження засвідчує, що для яванського селянина, котрий навряд чи коли зустрічав будь-яких "білих", крім голландців, ці два значення, по суті, збігалися. Подібним чином на французьких колоніальних територіях “les blancs” означало правителів, французькість яких була невід'ємною від білого кольору шкіри. Наскільки мені відомо, в жодному з цих випадків londo чи blanc не породили похідних принизливих означень ${ }^{25}$.

Якраз навпаки, дух антиколоніального націоналізму виявляється, приміром, у дивовижній Конституції недовговічної Республіки Катагалуган (1902) Маріо Сакая, в якій, між іншим, говориться ${ }^{26}$ :

Жоден тагаложець, що народився на архіпелазі Тагалог, не повинен вивишувати будь-кого над іншими в силу його раси чи кольору шкіри; світлі, темні, багаті, бідні, освічені й непись

\footnotetext{
${ }^{2 .}$ Я ніколи не зустрічав в індонезійській чи яванській мові образливого жаргонного слова на означення "голландця" або "білого". Чого не скажеш про англо-саксонську скарбницю: тут тобі й niggers (негритоси), i wops (макаронники), i kikes (пархаті), i gooks (чурки), i slants (косі), i fuzzywuzzies (чорнозаді), й десятки інших призвиськ. Ймовірно, шо подібна цнотливість расистських жаргонів стосується перш за все колонізованих народностей. Негритянське населення Америки - та й не тільки - виробило свій своєрідний контр-словник на означення білих (honkies, ofays тошо).

${ }^{26}$ Зацитовано 3: Reynaldo Ileto. Pasyon and Revolution: Popular Movements in the Philippines, 1840-1910, p. 218. Бунтівна республіка Сакая протривала до 1907 року, коли його захопили в полон і стратили американці. Щоб зрозуміти перше речення, необхідно пам'ятати, що після трьох століть іспанського правління й китайської імміграції на островах з'явилася велика кількість метисів.
} 


\section{УЯВЛЕНІ СПІЛЬНОТИ}

менні - всі $\epsilon$ абсолютно рівними й приналежними до одного loób [внутрішнього духа]. Люди можуть різнитися за своєю освітою, заможністю чи зовнішнім виглядом, але ніколи за своєю глибинною природою (pagkatao) та здатністю служити справі.

Можна досить легко відшукати аналогії на протилежному боці земної кулі. Іспаномовні мексиканські метиси ведуть свій родовід не від кастільських конкістадорів, а від напіввинищених ацтеків, майя, толтеків і запотеків. Уругвайські революційні патріоти, які самі є креолами, підхопили ім'я Тупака Амару, останнього з видатних тубільних повстанців проти креольського гноблення, який помер 1781 року після неймовірних тортур.

Може видатися парадоксальним, що об’єкти такої відданості є "уявленими" - анонімними, безликими співвітчизниками-тагаложцями, винищеними племенами, Росію-матір'ю або tanah air. Проте amor patriae не відрізняється в цьому відношенні від інших захоплень, в яких завжди присутній елемент зворушливого уявлювання. (Ось чому розглядання фотоальбому з чужого весілля нагадує ознайомлення 3 археологічним планом Висячих Садів Вавилону.) Чим $є$ для закоханої людини око - звичайнісіньке око, з яким він чи вона народилися - тим є для патріота мова, якою б історія його не наділила. Завдяки цій, спожитій з молоком матері мові, з якою розлучаються тільки на смертному одрі, оживає минуле, уявляються співдружності й вимріюється майбуття. 
Ангел Історії

Ми розпочали це коротке дослідження з недавніх війн між Соціалістичною Республікою В'єтнам, Демократичною Кампучією й Китайською Народною Республікою; отож доречним було $б$ повернутися до цієї вихідної точки. Чи допоможе щось із сказаного досі краще зрозуміти, що саме послужило причиною цих війн?

У “Розпаді Британіі” Том Нейрн висловлює цінні спостереження про відносини між політичними системами Британії й решти сучасного світу ${ }^{1}$.

Тільки у випадку [Британської системи] спостерігаємо "поступовий, органічний розвиток, на відміну від інших, що стали результатом свідомого винаходжування, заснованого на теоріі”. З'явившись пізніше, вони "намагалися відразу скористатися досвідом держави, яка виробляла свій конституціоналізм протягом кількох сторіч"... Будучи першим, англійський - а згодом британський - досвід залишався виразно своєрідним. Прийшовши у світ, де вже перемогла й поширила свій вплив Англійська революція, наступні

\footnotetext{
${ }^{1}$ Стор. 17-18. Виділено нами. Внутрішні цитати запозичені з: Charles Frederick Strong. Modern Political Constitutions, p. 28. 
буржуазні суспільства не могли пройти увесь ії шлях. Його вивчення й наслідування породило цілковито новий феномен: дійсно модерну доктрину абстрактної або "об'єктивної” держави, яку, завдяки ї̈ абстрактній природі, можна було б імітувати впродовж наступного історичного періоду.

Це, звичайно, можна вважати нормальною логікою еволюційних процесів. То був ранній зразок того, що пізніше удостоїлось таких титулів, як "закон нерівномірного й комбінованого розвитку". Дійсне повторення й імітація, політична чи економічна, соціальна чи технологічна, навряд чи можливі, адже світ вже невпізнанно змінено першопричиною, яку намагаються скопіювати.

Те, що Нейрн говорить про модерну державу, не меншою мірою стосується й концепцій-близнюків - революції та націоналізму - сучасними реалізаціями яких є згадані три соціалістичні країни. Надто легко забувають, що подібно до капіталізму й марксизму ці близнюки також є винаходами, патенти на які ніяк неможливо захистити. Вони, так би мовити, стають поживою для піратського копіювання. Саме завдяки цьому піратству і тільки завдяки йому можливі загальновідомі непорозуміння: суспільства, подібні до кубинського, албанського чи китайського, будучи революційно-соціалістичними, вважають, що знаходяться "попереду" суспільств Франції, Швейцарії й Сполучених Штатів. У той же час через низьку продуктивність праці, жалюгідні життєві стандарти й відсталу технологію вони, безумовно, сприймаються як "відсталі". (Звідси й меланхолійна мрія Чжоу Еньлая наздогнати 2000 року капіталістичну Британію.)

Як відзначено вище, Хобсбоум слушно зауважив, що “Французька Революція не була здійснена чи керована ні партією або рухом в сучасному сенсі, ані людьми, які намагалися втілити якусь послідовну програму". Та завдяки капіталістичному друкарству французький досвід не тільки назавжди закарбувався в людській пам'яті, але й став свого роду підручником. Після майже столітнього теоретизування й практичного експериментування на сцені з'явилися більшовики, що здійснили першу успішну "заплановану" револю- 
цію (навіть, якщо її успіх був неможливим без перемог Гінденбурга під Танненбергом і на Мазурських озерах) та намагалися впровадити системну програму (навіть, якщо на практиці панувала суцільна імпровізація). Здається також очевидним, що без таких планів і програм здійснення революції в країні, яка лише вступала в добу промислового капіталізму, було б нереальним. Більшовицька революційна модель виявилась визначальною для всіх революцій ХХ ст., бо їх стало можливо уявити в суспільствах, ще відсталіших від російського. (Це відкрило можливість, так би мовити, мандрувати історією “навпростець”.) Умілі ранні експерименти Мао Цзедуна підтвердили практичність цієї моделі поза межами Свропи. Спостерігати за кульмінацією цього процесу можна на прикладі Камбоджі, де 1962 року з працездатного населення в два 3 половиною мільйони "робітничий клас" налічував менше 2,5\%, а "капіталісти" менше 0,5 процента2.

Націоналізм, починаючи від кінця XVIII ст., проходив досить подібний процес модуляції й адаптації, достосовуючись до різних епох, політичних режимів, економічних і соціальних структур. В результаті, "уявлена спільнота" поширилась на кожне мислиме сучасне суспільство. Якщо Камбоджа ілюструє екстремальний випадок трансплантації "революційного" взірця, В'єтнам може служити прикладом перенесення націоналізму. Зробімо короткий екскурс в історію походження назви цієї нації.

Після коронації 1802 року Джіа-лонг забажав назвати своє королівство "Nam Vięt" і вислав посланців, шоб здобути згоду Пекіна. Манчжурський Син Небес наполіг, однак, на назві "Vięt Nam". Підставою для такої інверсії було наступне: "Vięt

\footnotetext{
${ }^{2}$ Згідно з розрахунками Едвіна Велса на основі таблиці 9 у: Cambodge, Ministere du Plan et Institute de la Statistique et des Recherches Economiques, Resultats finals du Recensement General de la Population 1962. Велс наступним чином розподіляє решту населення: урядові службовці й нова дрібна буржуазія, 8\%; традиційна дрібна буржуазія (крамарі й т.п.), 7,5\%; аграрний пролетаріат, 1,8\%; селяни, 78,3\%. Всього налічувалося менш ніж 1,300 капіталістів, шо володіли справжніми мануфактурними підприємствами.
} 


\section{УЯВЛЕНІ СІІЛЬНОТИ}

Nam" (або китайською Yüeh-пап) означав, приблизно, "на південь від Vięt (Yüeh)", тобто від завойовано1 сімнадцять століть тому династією Хань області, розташованоі, як гадають, на території нинішніх китайських провінцій Квантун і Квансі, а також у долині Червоної Ріки. "Nam Vięt" Джіалонга означав, однак, “Південний Vięt/ Yüeh”, що містило претензії на китайську територію. За словами Александра Вудсайда, "назву «В'єтнам», нав'язану Пекіном, сто років тому в'єтнамські правителі навряд чи поважали так високо, як у нинішнъому столітті. Це штучне ім'я не вживалось широко ні китайцями, ні в'єтнамцями. Китайці користалися образливим танським словом «Аннам»... В'єтнамський двір, зі свого боку, винайшов у 1838-39 рр. іншу назву для свого королівства й не потурбувався, щоб повідомити про це китайців. Його нова назва, Dai Nam, «Великий Південь» або «Імперський Південь», регулярно з'являлася в придворних документах та офіційних історичних компіляціях. Проте вона не дожила до нашого часу"”. Ця нова назва цікава у двох відношеннях. По-перше, в ній немає жодного "В'єт"намського компоненту. По-друге, іiі територіальний зміст цілком залежний - "південь" (Середньої імперіi)".

Tе, що сьогоднішні в'єтнамці гордо відстоюють Vièt Nam, вигаданий зневажливо Манчжурським династом XIX ст, нагадує нам вислів Ренана про те, що націі, мабуть, "oublie bien des choses", але також, як це не парадоксально, підкреслює силу уяви націоналізму.

Якщо подивитись на В'єтнам 1930-х років або Камбоджу 1960-х, можна віднайти, mutatis mutandis, багато спільного: величезні маси неписьменного, пригнобленого селянства,

${ }^{3}$ Vietnam and the Chinese Model, pp. 120-121.

4 Тут немає нічого дивного. "В'єтнамський бюрократ нагадував китайця" в'єтнамський селянин нагадував південно-східного азіата. Бюрократ мусив писати китайською мовою, вбиратися в китайському стилі мешкати в будинках китайського типу, пересуватися в паланкінах ки тайського вигляду й навіть переймати характерні зовнішні особливост] китайського споживацького стилю, такі як утримання ставків із золотими рибками в своїх південно-східноазіатських садах“. Ibid., p. $19 y$ y. 


\section{АНГЕЛ ICTOPII}

невеличкий робітничий клас, фрагмснтарна буржуазія й малочисельна, розмежована інтелігенція". Жодний тверезомислячий аналітик, об'єктивно оцінюючи умови, не міг би передбачити в будь-якому з цих випадків передумов для несподіваного спалаху революцій та їх катастрофічних тріумфів. (Насправді майже те саме й з тотожних причин можна сказати про Китай 1910 року.) Якщо ж сталося інакше, то завдяки "плануванню революції" та "уявлюванню націі”,"

Політичний курс режиму Пол Пота лише незначною мірою можна пояснити традиційною кхмерською культурою або притаманній його лідерам жорстокості, параної чи манії величності. Кхмери мали достатньо деспотів, що страждали мегаломанією; і деяким з них ми завдячуємо Ангкором. Набагато важливішими виявилися запозичені з Франції, СРСР, Китаю та В'єтнаму моделі того, що революції мусять, можуть, повинні й не повинні робити, та всі присвячені цьому франкомовні книжки ${ }^{7}$.

` Згідно з переписом 1937 року, 93-95\% в'єтнамського населення все ше проживали в сільській місцевості. Не більше $10 \%$ населення володіли функціонально будь-якою писемністю. Не більше 20,000 осіб закінчили повні початкові школи (7-10 класи) між 1920 і 1938 роками. А ті, кого в'єтнамські марксисти називали "корінною буржуазією" - за описами Марра, переважно землевласники, що здавали землю в оренду, плюс деякі підприємці й ряд вищих службовців - налічували в цілому близько 10,500 сімейств, або приблизно 0,5\% населення. Vietnamese Tradition, 25-26, 34 and 37. Порівняйте з даними, наведеними вище у 2-ій примітці.

А також, як у випадку з більшовиками, завдяки сприятливому збігу всіляких катастрофічних ситуацій: для Китаю це було масове японське вторгнення 1937 року; для В'єтнаму - прорив лінії Мажіно й короткочасна японська окупація; для Камбоджі - масивне перенесення американських воснних дій з В'єтнаму на їі східні території після березня 1970 року. В кожному з цих випадків ancien regime, будь то Гоміндан, колоніальний французький чи феодально-монархічний, виявлявся смертельно підточеним сторонніми силами.

“Можна, скажімо, на рахунок Франції віднести відповідь "так" терору і levee en masse, "ні" термідору й бонапартизму; на рахунок Радянського Союзу - "так" військовому комунізму, колективізації й московським судовим процесам, "ні" НЕПу й десталінізації; на рахунок Китаю - "так" партизансько-селянському комунізму, Великому Стрибку й культурній 
Майже все це справедливо й щодо націоналізму. Сучасний націоналізм є спадкоємцем двох століть історичних перемін. Ця спадщина, в силу всіх зазначених мною причин, $є$ справді дволикою. Адже серед спадкодавців можна зустріти не тільки Сан Мартіна й Гарібальді, але й Уварова та Маколея. Як ми вже пересвідчились, “офіційний націоналізм” від самого початку був свідомою, спрямованою на самозахист політикою, тісно пов'язаною зі збереженням імперськодинастичних інтересів. Проте, як тільки він опинився " у всіх на виду", його вже могли копіювати, неначе прусські військові реформи початку XIX ст., різноманітні політичні й соціальні системи. Однією зі сталих рис цього типу націоналізму була його офіційність - те, що він твориться державою й служить перш за все інтересам держави.

Таким чином, модель офіційного націоналізму стає важливою саме тоді, коли революціонери успішно захоплюють контроль над державою і вперше можуть використовувати державну владу для здійснення своїх візій. Офіційний націоналізм тим важливіший, оскільки навіть найрадикальніші революціонери певною мірою успадковують державний механізм від поваленого режиму. Його спадщина може бути символічною, проте її вага від того не зменшується. Попри сумніви Троцького, столицею СРСР знову стала стара царська столиця Москва; і протягом понад 65 років керівники КПРС розробляли свою політику в Кремлі, в цій древній цитаделі царської влади - вибраній з усіх можливих місць на просторах соціалістичної держави. Подібним чином, столицею КНР залишається столиця Манчжурської династії (тоді як Чан Кай-ші переніс її до Нанкіну), а лідери ККП збираються в Забороненому Місті Синів Небес. Фактично, майже немає соціалістичних лідерів, які б не пригрілися в цих поношених, але затишних кріслах. На менш очевидному

революції, "ні" Люшанському пленуму; на рахунок В'єтнаму - "так" серпневій революції й формальній ліквідапії 1945 року індокитайської комуністичної партії, “ні” поступкам "старшим" компартіям, зафіксованим у Женевських угодах. 


\section{АНГЕЛ ICTOPII}

рівні, успішні революціонери успадковують ие й усю приховану мережу старої держави: інколи функціонерів та інформаторів, але переважно картотеки, досьє, архіви, кодекси законів, фінансову документацію, дані переписів, карти, угоди, кореспонденцію, меморандуми тощо. Немов складна електромережа великого будинку, покинутого власником, держава очікує, коли новий господар торкнеться рукою вимикача, щоб знову засіяти повним блиском.

Тому не варто дивуватися, коли революційні лідери свідомо чи несвідомо починають грати роль власника маєтку. Ми тут не маємо на увазі лише самоідентифікацію Джугашвілі з Іваном Грозним, або виразне захоплення, з яким Мао ставився до тирана Чин Ши Гуан-ті, або відродження Йосифом Броз Тіто руританської помпезності й церемоніалу" “Офіційний націоналізм” дає себе знати в манерах постреволюційних керівників більш витонченим чином. Я маю на увазі те, що ці керівники надто легко визнають фіктивну національність колишніх династів та династичних держав. Династичні правителі, які не мали жодного уявлення про “Китай”, “Югославію”, “В’етнам” чи "Камбоджу”, ставали, так би мовити, заднім числом національними діячами (навіть, якщо не завжди "гідними" того). Подібна практика неминуче породжує "державний” макіявеллізм, котрий так разюче відрізняє післяреволюційні режими від революційних націоналістичних рухів. Чим більше натуралізується давня династична держава, тим краще лежить ії старовинна мантія на революційних плечах. Образ Ангкору Джайявармана VII, яким прикрашений прапор марксистської Демократичної Кампучії (а також маріонеткової республіки Лон Нола й монархічної Камбоджі Сіанука), є символом влади, а не благочестя .

${ }^{8}$ Див. надзвичайний опис, у жодному разі не цілковито полемічний, y: Milovan Djilas, Tito: the Story from Inside, chapter 4, especially pp. $133 \mathrm{ff}$.

Безперечно, окреслені вище тенденції характерні не лише для революційних марксистських режимів. Ми зосередили увагу на них в силу як історичної марксистської відданості пролетарському інтернаціоналізму 


\section{УЯВЛЕНІ СІІЛЬНОТИ}

Я наголошую на керівниках, бо саме керівництво, а не прості люди, успадковує старі щити управління й палаци. Ніхто, я сподіваюся, не припускає, що широкі маси китайського народу переймаються тим, що діється вздовж колоніального кордону між Камбоджею та В'єтнамом. Цілком неймовірно також, щоб кхмерські й в'єтнамські селяни бажали війн між своїми народами, або щоб хтось із ними з цього приводу радився. Все це були в буквальному смислі "канцлерські війни", коли масовий націоналізм мобілізовувався здебільшого постфактум і завжди під гаслом самооборони. (Звідси й особливо низький рівень ентузіазму в Китаї, де такі гасла викликали найменше довір'я, навіть коли супроводжувалися закликами про загрозу "радянського гегемонізму"“ ).

У цьому смислі Китай, В'єтнам і Камбоджа зовсім не унікальні ${ }^{11}$. Ось чому існуе мало підстав сподіватися, що встановлені ними прецеденти війн між соціалістичними країнами не будуть наслідуватись, або що уявлена спільнота соціалістичної нації стане невдовзі зайвою. Але ми не зробимо нічого, щоб обмежити або припинити ці війни, поки не облишимо вигадки типу "марксисти як такі не є націоналістами" чи "націоналізм - це патологія модерної еволюційної історії", й натомість не прикладемо поступово всіх зусиль для опанування як справжнього, так і уявленого досвіду минулого.

Волтер Бенджамін написав про Ангела Історії, що :

та руйнуванню феодальних і капіталістичних держав, так і нових індокитайських війн. Шодо аналізу архаїчної іконографії реакційного режиму Сухарто в Індонезії, див. мою працю: Language and Power: Exploning Political Cultures in Indonesia, chapter 5.

${ }^{10}$ Різниця між винаходами "офіційного націоналізму" та інших його типів полягає зазвичай у відмінності поміж брехнею й міфами.

${ }_{11} 3$ іншого боку, ймовірно, що наприкінці цього століття історики стануть пояснювати ексцеси "офіційного націоналізму", до яких вдавалися післяреволюційні соціалістичні режими, неспівпадінням соціалістичного ідеалу й аграрної дійсності.

${ }^{12}$ Illuminations, p. 259. Ангельське око-це телекамера програми "Weekend", повернена назад, перед якою на безконечній автостраді з'явля оться на мить одна за другою картини катастроф, перед тим, як зникнути за горизонтом. 


\section{АНГЕЛ ICТОРI}

Його обличчя обернене в минуле. Там, де нам ввижається ланцюг подій, він бачить один вічний катаклізм, що, нагромаджуючи уламки на уламки, жбурляє іх йому під ноги. Ангел волів би залишатися, будити мертвих і робити цілим все, вщент розбите. Але з раю на нього налітає ураганний вітер; він із такою люттю розвіває йому крила, що ангел вже не годен їх зімкнути. Цей ураган нездоланно відносить його в майбутнє, до якого він повернений спиною, тоді як перед ним зростає до небес купа уламків. Цей ураган ми називаємо прогресом.

Але Ангел є безсмертний, а наші обличчя зазирають до пітьми, що попереду. 


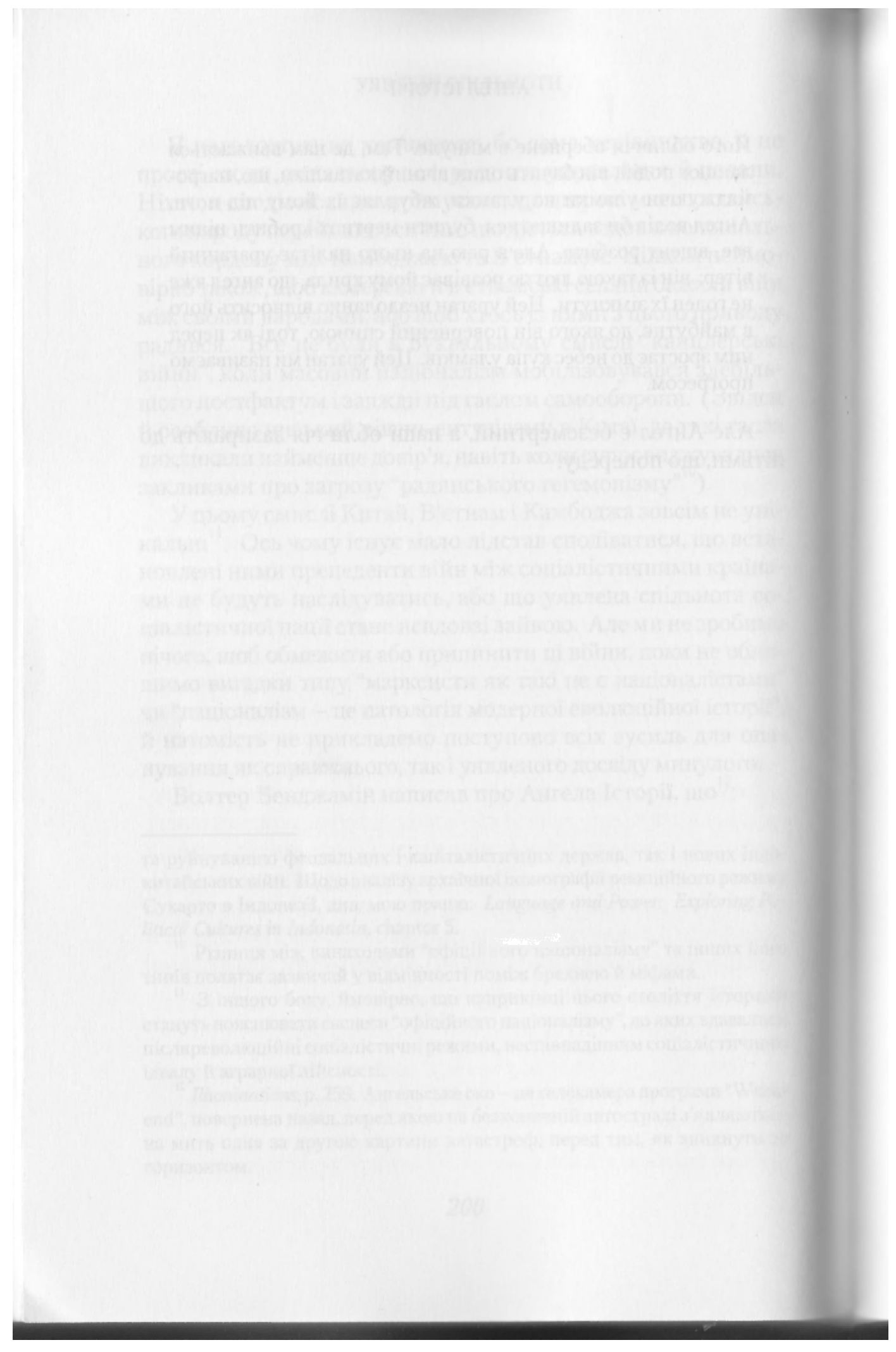


Перепис, карта, музей

У першому виданні "Уявлених спільнот" я писав, що "надто часто в політичному курсі нових держав на «національне будівництво» можна віднайти сліди як щирого й масового національного ентузіазму, так і систематичного, навіть мак'явеллівського, прищеплювання націоналістичної ідеології через засоби масової інформації, освітню систему, урядові постанови тощо”" . Тоді я недалекоглядно припускав, що офіційний націоналізм колонізованих світів Азії й Африки брав собі за взірець подібний націоналізм династичних держав Європи XIX ст. Пізніші розмірковування переконали мене в тому, що така точка зору була поспішною й поверховою, і що безпосередню генеалогію треба шукати в уявлюваннях колоніальної держави. На перший погляд, цей висновок може здаватись несподіваним, адже колоніальні держави були типово, а часом радикально анти-націоналістичними. Але якщо зазирнути під покров колоніальних ідеологій та політик і зрозуміти логіку, на яких ці режими базувалися від середини XIX ст., генеалогія стає очевиднішою.

\footnotetext{
${ }^{1}$ Див. VII розділ.
} 


\section{УЯВЛЕНІ СПЈЈНОТИ}

Нішо не виявляє цієї логіки рельєфніше, ніж три інституції влади, хоча й винайдені раніше від середини XIX ст., проте цілковито трансформовані після того, як колонізовані регіони увійшли в добу механічного репродукування. Цими трьома атрибутами є перепис, карта й музей: вони спільно формували спосіб, в який колоніальна держава мислила і уявляла себе - природу підвладних їй людських істот, географію своїх володінь і легітимність свого походження. Щоб дослідити природу ї впливу, я зосереджу в цьому розділі увагу на Південно-Східній Азії, оскільки висновки мої попереднього характеру, а претензії на грунтовну спеціалізацію обмежені саме цим регіоном. Втім, для порівняльно-історичних досліджень Південно-Східна Азія пропонує вдячний матеріал, адже вона включає в себе території, колонізовані мало не всіма "білими" імперіями - Британією, Францією, Іспанією, Португалією, Нідерландами й Сполученими Штатами - а також неколонізований Сіам. Читачі, краще від мене обізнані з іншими частинами Азії й Африки, краще за мене оцінять, чи мої висновки справедливі також щодо інших територій і інших часів.

\section{Перепис}

Соціолог Чарлз Гіршман у двох нещодавніх своїх статтях започаткував дослідження mentalites британських колоніальних чиновників, відповідальних за перепис населення Колоній Протоки й Малайського півострова, та їхніх наступників, котрі працювали на незалежну державу Малайзію². Опубліковані Гіршманом факсимільні копії ряду переписів, починаючи від кінця XIX ст. й дотепер, демонструють цілу серію надзвичайно швидких, поверхових і довільних змін, у ході яких ці "категорії ідентичності" постійно нагромаджу-

\footnotetext{
${ }^{2}$ Charles Hirschman. "The Meaning and Measurement of Ethnicity in Malaysia: An Analysis of Census Classifications", J. of Asian Studies, 46:3 (August 1987) pp. 552-582; а також "The Making of Race in Colonial Malaya: Political Economy and Racial Ideology", Sociological Forum, 1:2 (Spring 1986), pp. 330-362.
} 
IIЕРЕПИС, КАРТА, МУ:ЗЕ:И

валися, розподілялися, перекомбіновувалися, перемішувалися й реорганізовувалися (проте політично вагомі категорії ідентичності незмінно очолювали список). На основі цих переписів дослідник приходить до двох головних висновків. По-перше, чим довшою була колоніальна епоха, тим критерії перепису ставали все очевидніше, а часом і виключно, расовими ${ }^{3}$. Релігійна ідентичність, з іншого боку, поступово зникала як основна категорія перепису. "Індуси" - що стояли в одному ряді з “клінгами" й "бенгальцями" - щезли після першого перепису 1871 року. "Парси" протривали до перепису 1901 року, в якому вони ще з'явилися - разом із "бенгальцями", "бірманцями" й "тамілами" - під загальною категорією “таміли й інші корінні мешканці Індії”. Другий висновок Гіршмана полягав у тому, що великі расові категорії після здобуття незалежності загалом були збережені й навіть укрупнені, але тепер їх було переназвано і перегруповано на "малайзійців", "китайців", “індійців" та "інших". Проте аномалії зустрічалися ще й у 1980-х роках. У переписі 1980 року "сикхи" все ще були боязко віднесені до псевдоетнічної підкатегорії - поруч із “малайялі" й “телегу”, “пакистанцями” й "бангладешцями", "шріланкськими тамілами" й “іншими шріланкійцями” - під загальною рубрикою “індійці".

Але чудові факсимільні копії Гіршмана заохочують нас вийти за рамки його безпосередніх аналітичних зацікавлень. Візьмімо, приміром, перепис Федеративних Малайських IШтатів, в якому під рубрикою "Раси Малайського населення" знаходяться: "малайці”, “яванці”, “сакайці”, “банджарійці”, "бойянійці”, “менделінг” (sic), "крінчі” (sic), “джамбійці”, "ачінійці", "бугійці" та "інші”. 3 оцих груп усі, крім (здебільшого) "малайців" і “сакайців”, походили з островів Суматра,

${ }^{3}$ Протягом колоніальної епохи переписи фіксують дивовижне розмаїття "європейців". Але коли 1881 року їх ще зараховували переважно до рубрик "постійний мешканець", “тимчасовий житель" і “в'язень", то в 1911 р. їх усіх вже охоплювала рубрика "представників (білої) раси". Цікаво, що до останнього часу автори переписів явно вагалися, до якого розряду віднести тих, кого вони визначали "євреями". 
Ява, Південне Борнео й Сулавесі, тобто частин великої сусідньої колонії Голландська Східна Індія. Але їх позамалайське походження не справило жодного враження на авторів перепису, котрі, створюючи своїх “малайців”, скромно обмежували свій горизонт лише власними колоніальними кордонами. (Зрозуміло, що голландські переписувачі по той бік протоки творили інший образ "малайців" як етнічної меншини на однаковому, а не вищому рівні від "ачінійців", "яванців" та інших.) Назви "джамбійці” й “крінчі" скоріше походження 3 певних місцевостей, аніж на щось, бодай віддалено подібне до етнолінгвістичної категорії. Майже неймовірно, щоб 1911 року хто-небудь, крім невеличкої кількості людей, розподілених по категоріях і підкатегоріях, упізнав би себе під цими ярликами. Подібні “ідентичності”, виображені (часом, помилково) уявою колоніальної держави, все ще очікували на свою матеріалізацію, яку проникнення колоніальної адміністрації невдовзі зробить можливою. Можна помітити при тому пристрасть переписувачів до вичерпності й недвозначності. Звідси й їхня нетерпимість до складних, політично "трансвеститних", нечітких або мінливих ідентифікацій. Звідси й дивна підкатегорія “Інші” у кожній з расових груп, яких, проте, в жодному разі не можна було плутати з іншими "Іншими". Фікція перепису полягає в тому, що кожен знаходить в ньому своє - одне-єдине - абсолютно чітке місце. Жодних відхилень.

Витоки цього типу мислення колоніальних держав значно старші за переписи 1870-х років, отже, щоб краще зрозуміти новаторство переписів кінця XIX ст., варто звернутися до початків європейського проникнення у Південно-Східну Азію. Повчальними є два приклади, що походять із Філіппінського й Індонезійського архіпелагів. У своїй останній вельми цінній книзі Вільям Генрі Скотт спробував ретельно відтворити класову структуру до-іспанських Філіппін на основі найраніших іспанських свідчень . Як професійний

\footnotetext{
${ }^{4}$ William Henry Scott. Cracks in the Parchment Curtain, chapter 7, "Filipino Class Structure in the Sixteenth Century".
} 
історик, Скотт прекрасно знає, що Філіппіни завдячують своїй назві Філіппу II “іспанському", й що коли 6 не випадок, архіпелаг міг би опинитися в голландських чи англійських руках, стати політично роздробленим або знову об'єднатися шляхом подальших завоювань ${ }^{5}$. Спокусливо тому приписати цей несподіваний вибір теми його тривалому проживанню в Філіппінах та симпатіями до філіппінського націоналізму, який ось уже протягом століття перебуває в пошуках первісного Едему. Можливо, втім, значно глибший вплив на формування його поглядів справили джерела, на які він був змушений покладатися. Адже фактом залишається те, що на які 6 острови не висаджувалися перші духівники й конкістадори, вони там бачили principales, hidalgos, pecheros and esclavos (принців, вельмож, простолюдинів і рабів) - представників суспільних станів, запозичених із соціальної ієрархії пізньосередньовічної Іберії. Документи, залишені ними, повні свідчень, що "hidalgos" величезного, розкиданого й рідконаселеного архіпелагу переважно не здогадувались про існування один одного, а коли й здогадувались, то бачили, замість hidalgos, ворогів або потенційних рабів. Але сила схеми виявилася такою великою, що Скотт лишає ці свідчення на узбіччі свідомості, а отже не бачить, що "класова структура" доколоніальної епохи витворена уявою "переписувачів", що дивилися на світ з високої корми іспанських галеонів. Де 6 вони не опинялися, одразу множили hidalgos

\footnotetext{
${ }^{5}$ В першій половині XVII ст. іспанські поселення архіпелагу були об'єктом неодноразових збройних нападів з боку Vereenigde Oost-Indische Compagnie, найбільшої "транснаціональної" корпорації тієї доби. Своїм виживанням побожні католицькі поселенці величезною мірою завдячують єретику протектору, який більшу частину свого правління стримував войовничі прагнення Амстердама. Якби VOC досягла успіху, центром абсолютної голландської влади в Південно-Східній Азії стала б не Батавія [Джакарта], а Маніла. 1762 року Лондон відібрав Манілу в Іспанії й утримував її майже два роки. Кумедно, але Мадрид повернув іiї лише в обмін на - хто б міг подумати!- Флориду та інші “іспанські" володіння на схід від Міссісіпі. Якби переговори завершилися інакше, архіпелаг міг би протягом XIX ст. бути політично об'єднаним із Малайєю та Сінгапуром.
} 


\section{УЯВЛЕНІ СПІЛЬНОТИ}

та esclavos, бо тільки так народжена колоніальна держава могла увібрати тих до своєї структури.

Стосовно Індонезії ми маємо, завдяки дослідженню Мейсона Хоудлі, детальний звіт про важливу судову справу, що слухалася наприкінці XVII ст. в порту Черібон на узбережжі Яви ${ }^{6}$. На щастя, досі збереглись як голландські (Східноіндійської компаніі), так і черібонійські документи. Якщо б існував тільки черібонійський звіт, ми знали б обвинуваченого вбивцю лише за високою посадою у черібонійському суді, і тільки за титулом Кі Арія Марта Нінграт, а не особистим ім'ям. Документи компанії, однак, гнівно називають його Chinees - і це найважливіша інформація про особу звинуваченого, яку вони надають. Цілком очевидно, що черібонійський суд розподіляв людей за їхнім рангом і статусом, тоді як Компанія класифікувала іх за "расою". Немає жодних підстав припускати, ніби підсудний вбивця - чий високий статус свідчить про його власну та його предків давню інтегрованість до черібонійського суспільства, незалежно від походження - сприймав себе одним із Chinees. Чому ж Компанія класифікувала його таким чином? На кормі яких кораблів виобразили цих Chinees? Безперечно, на тих торгових кораблях, що під централізованим командуванням безперервно курсували з порту до порту між Мергвійською затокою й гирлом Янцзи-к'ян. Не помічаючи різноманітних народностей Серединної імперії, взаємної незрозумілості їхніх розмовних мов і соціальних та географічних особливостей їхньої діаспори на узбережжі Південно-Східної Азії, Компанія уявила своїм трансокеанським оком безконечний ряд Chinezen, подібно до того, як конкістадорам увижався нескінченний ряд hidalgos. I на основі цього нехитрого перепису вона почала наполягати, щоб підконтрольні ій особи, кого вона віднесла до категорії Chinezen, вбиралися, жили, одружувалися, вмирали й заповідали майно у відповідності з цим переписом. Цікаво, що іберійці з Філіппін, що набагато

${ }^{6}$ Mason C. Hoadley. "State vs. Ki Aria Marta Ningrat (1696) and Tian Siangko (1720-21)" (рукопис, 1982). 


\section{ПЕРЕПИС, КАРТА, МУЗЕЙ}

менше подорожували й не були настільки комерційно налаштованими, уявили цілком інакшу категорію перепису, яку вони назвали sangley. Слово sangley виникло в результаті залучення до іспанської мови гоккайського sengli - що означало "торговець". Можна собі уявити перших іспанських переписувачів, які запитували в торговців, приваблених до Маніли розвитком морської комерції: “Хто ви такі?”, на що лунала розважлива відповідь: “Ми - торговці". Іберійці, котрі не перепливали сім азіатських морів, залишалися протягом двох століть у затишно провінційній концептуальній імлі. Дуже й дуже повільно sangley перетворювався в "китайця" - поки це слово не зникло на початку дев'ятнадцятого сторіччя, щоб поступитися chino цілком у стилі голландської Східноіндійської компанії.

Справжнім нововведенням переписувачів 1870 -х років було, отже, не створення етнічно-расових категорій, а скоріше їхня систематизація й кількісне визначення. Доколоніальні правителі малайсько-яванського світу робили спроби підрахунку підлеглого їм населення, але тільки у вигляді реєстрів платників податків та списків новобранців. Вони мали конкретну й специфічну мету: відстежувати тих, iз кого можна збирати податки й кого можна набирати до війська - адже цих правителів цікавили тільки економічні надходження й військові людські ресурси. Перші європейські режими регіону не дуже відрізнялися в цьому відношенні від своїх попередників. Але після 1850 року колоніальна влада почала використовувати дедалі витонченіші адміністративні засоби для підрахунку населення, у тому числі жінок і дітей (яких завжди ігнорували давніші правителі), у відповідності зі складними класифікаціями, які не переслідували жодних безпосередніх фінансових або військових цілей. В старі часи

\footnotetext{
${ }^{7}$ Див., наприклад: Edgar Wickberg. The Chinese in Philippine Life, 1850 1898, chapters 1 and 2.

${ }^{8}$ Каравани комерційних галеонів - для яких Маніла була протягом двох століть таким собі entrepôt [товарним складом] - обмінювали китайський шовк і порцеляну на мексиканське срібло.
} 
піддані, що підлягали оподаткуванню або набору до війська, переважно чітко усвідомлювали те, що вони перебувають під обліком; правителі й піддані тут добре розуміли один одного, хоча й $з$ антагоністичних причин. Але вже в 1870 році “кочинкитайська" жінка, що не платила податків й не підлягала військовому набору, могла прожити ціле своє щасливе чи нещасне життя в Колоніях Протоки, не маючи найменшого уявлення про те, що саме таким чином її класифікували десь там нагорі. Тут стає очевидною специфіка нового перепису. Він намагався ретельно перерахувати всі об'єкти своєї гарячкової уяви. Враховуючи природу класифікаційної системи й саму логіку кількісного вимірювання, "кочин-китаєць” мислився окремою одиницею сукупної серії відтворюваних "кочин-китайців" - у межах, звичайно, державних володінь. Нова демографічна топографія пускала глибоке соціальне й інституційне коріння, в міру того, як колоніальна держава помножувала свої обсяги й функції. Керуючись своєю уявленою картою, вона організовувала нову освітню, правову, медичну, поліцейську й імміграційну бюрократію, будуючи її на принципі етнічно-расових ієрархій, які, однак, розумілися як рівнозначні множини. Підлегле населення, протікаючи крізь тенета різноманітних шкіл, судів, клінік, поліцейських дільниць та імміграційних офісів, створювало "правила руху", які з часом вдихнули справжнє соціальне життя в давні фантазії держави.

Що й говорити, дорога була не завжди рівною, й держава нерідко наражалась на скрутні ситуації. Чи не найважливішим було досягнення релігійного узгодження, яке служило основою дуже старих, дуже стабільних уявлених спільнот, що жодною мірою не відповідали авторитарній класифікаційній схемі світської держави. В різних південноазіатських колоніях правителі були змушені знаходити різні шляхи для непростих компромісів, особливо $з$ ісламом і буддизмом. Продовжували, до речі, процвітати релігійні храми, школи й суди - доступ до яких визначався самостійним індивідуальним вибором, а не результатами перепису. Держава мало що могла вдіяти, крім спроб регулювати, обмежувати, облі- 
ковувати, внормовувати й підпорядковувати собі ієрархічно подібні інституції. Саме тому, що храми, мечеті, школи й суди являли собою топографічну аномалію, вони й сприймалися вільними зонами та - згодом - фортецями, з яких вирушали на битву релігійні, а пізніше націоналістичні антиколоніалісти. Водночас частими були спроби форсувати приведення перепису в повнішу відповідність з релігійними спільнотами шляхом - наскільки це було можливе - політичної й правової етнізації цих спільнот. У Федеративних Штатах колоніальної Малайї це завдання було відносно легким. Тi, кого режим відніс до категорії “малайці”, скеровувались до судів "їхніх" кастрованих султанів, шо значною мірою діяли згідно з ісламським законом ${ }^{10}$. Таким чином, назву “мусульманин" трактували просто як ще один варіант означення "малайця". (Лише після здобуття незалежності в 1957 році деякі політичні групи робили спроби зворотнього трактування, вважаючи, що насправді “малайці" с одним із різновидів "мусульман".) У величезній за розмірами, гетерогенній Голландській Індії, де під кінець колоніальної доби безліч ворогуючих місіонерських організацій на розпорошених територіях досягли значних успіхів у християнізації, аналогічна тенденція наштовхувалась на більш серйозні перешкоди. Проте навіть там у 1920-х і 1930-х роках спостерігався ріст кількості “етнічних" християн (Батакська Церква, Церква Каро, Дайякська Церква тощо), які виникли між іншим і тому, що держава розподілила серед різних місіонерських груп прозелітаційні зони у відповідності з топографією власних переписів. 3 ісламом Батавія не досягла подібних успіхів. Вона не наважилась заборонити паломництва до Мекки, хоча й намагалася стримати ріст паломників кількісно, контролювала їхні подорожі та слідкувала за ними 3 аванпосту в Джидді, заснованому саме з цією метою. Жоден із цих заходів

${ }^{9}$ Див. вище VII розділ, у якому згадуються спроби французького колоніалізму розірвати старі зв'язки камбоджійського буддизму з Сіамом.

${ }^{10}$ Див.: William Roff. The Origins of Malay Nationalism, pp. 72-74. 


\section{УЯВЛЕНІ СІІЛЬНОТИ}

не був достатнім для того, щоб перешкодити посиленню інтенсивних контактів мусульман Голландської Індії з величезним зовнішнім світом ісламу, а особливо з новими ідеями, що надходили з Каїру ${ }^{11}$.

\section{Карта}

Тим часом, однак, Каїр і Мекка починали несподівано візуалізуватися зовсім по-новому, вже не просто як певні пункти сакральної мусульманської географії, але й як цяточки на аркушах паперу, де подібними цяточками були вже позначені Париж, Москва, Маніла й Каракас; і площинний взаємозв'язок між цими безсторонньо світськими або сакральними цяточками не визначався нічим, окрім математично вирахованої прямої відстані. Карта Меркатора, занесена сюди європейськими колонізаторами, почала через друк формувати уяву південно-східних азіатів.

У своїй нещодавній блискучій дисертації таїландський історик Тхонгчай Вінічакул простежив за складними процесами, завдяки яким між 1850 і 1910 роками з'явився на світ "Сіам" зі своїми кордонами ${ }^{12}$. Цей опис є дуже повчальним саме тому, що Сіам не був колонізований, хоч те, по зрештою стало його кордонами, було визначене колоніальними державами. Отже, на прикладі Таїланду можна надзвичайно виразно прослідкувати за появою нового державного мислення в межах “традиційної” структури політичної влади.

До самого вступу на престол у 1851 році розсудливого Рами IV (Монгкута з книжки “Король $і$ я") в Сіамі існувало тільки два типи карт, до того ж ручної роботи: сюди ще не дійшла доба механічного репродукування. Один із них, який можна було назвати "космографічним", являв собою формальну, символічну репрезентацію Трьох Світів традиційної

\footnotetext{
${ }^{11}$ Див.: Harry J. Benda. The Crescent and the Rising Sun, chapters 1-2.

${ }^{12}$ Thongchai Winichakul. "Siam Mapped: A History of the Geo-Body of Siam" (Ph.D.Thesis, University of Sydney, 1988).
} 
буддистської космології. Космографічна карта, на відміну від звичних нам, не була організована горизонтально; вона складалася скоріше з ряду надземних райських і підземних пекельних світів, що вклинювались у світ видимий уздовж єдиної вертикальної вісі. Вона була непридатна для подорожей, хіба що в пошуках заслуг і спасіння душі. Другий тип, цілковито світський, складався зі схематичних путівників для військових кампаній і прибережного судноплавства. Організовані більш менш як квадранти, вони містили нотатки про часові відстані військових і морських маршрутів, необхідні тому, що автори карт не володіли технічною концепцією масштабу. Охоплюючи тільки наземний, світський простір, вони переважно мали дивну викривлену перспективу, або й суміш перспектив, так, ніби очі автора, що звикли щоденно бачити навколишній ландшафт горизонтально, на своєму рівні, відчували, однак, підсвідомий вплив вертикальності космографічної карти. Тхонгчай зазначає, що ці карти-путівники, які завжди були суто локальними, ніколи не розмішували своїх об'єктів в ширшому, стабільнішому географічному контексті, а звична для сучасних карт перспектива з пташиного польоту була для них абсолютно чужою.

Жодна з цих карт не позначала кордони. Елегантне формулювання Річарда Мюра для їхніх укладачів виявилося б незбагненним ${ }^{13}$ :

Специфічне значення міжнародних кордонів, розташованих на рубежах між суміжними державними територіями, поляraє у визначенні меж суверенної влади та у встановленні просторової форми підвладних їй політичних регіонів... Кордони...виникають там, де вертикальні рубежі державних суверенітетів перетинаються з поверхнею землі... Будучи вертикальними розмежуваннями, кордони не мають горизонтальної довжини...

Прикордонні камені та інші подібні віхи, звичайно ж, не тільки існували, але й помножувалися вздовж західних країв

\footnotetext{
${ }^{13}$ Richard Muir. Modern political Geography, p. 119.
} 


\section{УЯВЛЕНI СІІЛЬҢОТИ}

королівства, коли британці почали чинити тиск зі сторони Нижньої Бірми. Але ці камені встановлювалися час від часу на стратегічних гірських перевалах і бродах, причому нерідко на значних відстанях від відповідних каменів, поставлених супротивником. Мислилися вони горизонтально, на рівні очей, як віхи поширення королівської влади, а не звідкись “згори”. Лише в 1870-х роках тайські лідери почали сприймати кордони як сегменти безперервної лінії на карті, що не відповідає нічому видимому на землі, а відмежовує певний ексклюзивний суверенітет від суміжних суверенітетів. 1874 року з'явився перший підручник з географії американського місіонера Дж. В. Вен Дайка - ранній продукт капіталістичного друкарства, що вже опановував тоді Сіам. 1882 року Рама V заснував спеціальну картографічну школу в Бангкоку. 1892 року міністр освіти принц Дамронг Раджанупаб, започатковуючи в країні шкільну систему модерного типу, зробив географію обов'язковим предметом на рівні неповної середньої освіті. Десь у 1900 році, чи близько того, була видана "Phumisat Sayam" [Географія Сіаму] В. Г. Джонсона, яка відтоді служила моделлю для всіх друкованих географій країни ${ }^{14}$. Тхонгчай зауважує, що поєднання капіталістичного друкарства й нової концепції просторової реальності, представленої цими картами, мало безпосередній вплив на формування словника тайської політики. В період між 1900 і 1915 роками майже зникли традиційні слова krung і muang, адже вони змальовували поширення влади в термінах сакральних столиць і окремих, зримих населених пунктів ${ }^{15}$. Ix замінила, натомість, prathet, "країна", яка осмислювала владу в поняттях незримо обмеженого територіально простору .

Як і переписи, карти європейського типу діяли на основі узагальнюючої класифікації, підштовхуючи своїх творців і

\footnotetext{
${ }^{14}$ Thongchai. "Siam Mapped", pp. 105-110, 286.

${ }^{15}$ Для тих, кого цікавить повна дискусія шодо старих коцепций влади на Яві (що, з невеличкими відхиленнями, відповідають концепціям Старого Сіаму), див. мою працю "Language and Power", chapter 1.

${ }^{10}$ Thongchai. "Siam Mapped", p. 110.
} 
ПЕРЕПИС, КАРТА, МУЗГ:Й

споживачів до політики з революційними наслідками. Відтоді, як Джон Харрісон винайшов 1761 року хронометр, що дозволило точно розрахувати географічну довготу, ціла кулеподібна поверхня планети покрилася геометричною сіткою, що розкреслила на ретельно виміряні квадрати порожні моря й недосліджені регіони ${ }^{17}$. Завдання, так би мовити, "заповнення" цих квадратів було покладене на дослідників, топографів і військових. В Південно-Східній Азії друга половина XIX ст. стала золотим віком для військових топографів - колоніальних, а трохи згодом і місцевих тайських. Вони прагнули здійснити загальну інспекцію простору подібно до того, як укладачі переписів робили це з людьми. 3 кожною новою тріангуляцією, війною й угодою все далі просувалось взаємоузгодження карти та влади. За словами Тхонгчая ${ }^{18}$ :

3 точки зору більшості комунікаційних теорій та здорового глузду, карта являє собою наукову абстракцію реальності. Карта просто репрезентує те, що вже об'єктивно існує "там". Але в описуваній мною історії ці взаємовідносини помінялися місцями. Карта визначала просторову реальність, а не навпаки. Інакше кажучи, замість того, щоб наслідувати модель чогось, що вона мала 6 репрезентувати, карта сама була такою моделлю... Вона стала реальним інструментом для конкретизації проекцій на земній поверхні. Карта тепер стала необхідною новим адміністративним апаратам і військам для виправдання їхніх претензій... Картографічний дискурс став парадигмою, в межах якої та задля якої здійснювались як урядові, так і військові операції.

На порозі століття, після реформ принца Дамронга в міністерстві внутрішніх справ, королівський уряд зрештою став діяти на цілком територіально-картографічній основі, наслідуючи подібну практику сусідніх колоній.

\footnotetext{
${ }^{17}$ David S. Landers. Revolution in Time: Clocks and the Making of the Modern World, chapter 9.

${ }^{18}$ "Siam Mapped", p. 310.
} 


\section{УЯВЛЕНІ СПЈЛЬНОТИ}

Було б нерозумним випускати з уваги важливий зв'язок між картою й переписом. Адже нова карта рішуче розривала безконечні ряди "гаккайців", “нетамільських шріланкійців" i “яванців”, витворених формальним механізмом перепису, розмежовуючи, згідно з політичними цілями, ті територі1, на яких вони перебували. I навпаки, засобами тако1 собі демографічної тріангуляції перепис політично заповнював формальну топографію карти.

В ході цих змін і виниклии два остаточних аватари карти (обидва запроваджені пізньоколоніальною державою), які стали безпосереднім прообразом офіційних націоналізмів Південно-Східної Азії ХХ ст. Цілком свідомі свого статусу непроханих чужинців у далеких тропіках, але представляючи цивілізацію, в якій уже давно було утверджено легальну спадкоємність і легальну передачу географічних територій , свропейці часто намагались узаконити поширення своє1 влади напівлегальними методами. Серед найпопулярніших було “успадкування" уявних суверенних прав місцевих правителів, усунених або підпорядкованих європейцями. В будь-якому разі узурпатори займалися реконструкцією історії власності своїх нових володінь, особливо по відношенню до інших європейців. Звідси й поява, особливо наприкінці XIX ст., "історичних карт", задуманих для демонстраціі новою картографічною мовою древнього походження специфічних, чітко обмежених територіальних одиниць. 3 розтапюованої в хронологічному порядку послідовності таких карт народжувався політично-біографічний наратив державно1 історії, що часом сягав глибокої давнини ${ }^{2}$. Своєю чергою,

${ }^{19} Я$ не маю на увазі просто спадшину й продаж приватно1 земельно1 власності у звичному розумінні. Більш важливою була європейська практика політичної передачі земель разом із іхніми мешканцями в результаті династичних шлюбів. Одружившись, принцеси передавали сво1м чоловікам герцогства й дрібні князівства, й ці передачі формально узгоджувалися и "скріплялися підписом". Гасло "Bella gerant alii, tu, felix Austria, nube? неможливо було б уявити в будь-якій державі доколоніально1 Азі.

${ }^{20}$ Див. Thongchai. “Siam Mapped”, p. 387, стосовно засвоєння тайським правлячим класом подібного типу уявлювання. "Згідно з цими історич- 
цей наратив засвоювався, хоч інколи і в переробленому вигляді, національними державами, що у ХХ ст. стали спадкоємцями колоніальних держав ${ }^{21}$.

Другим аватаром стала карта-емблема. Походження іiі було досить безневинним - звичка імперських держав розмальовувати свої колонії на карті імперською фарбою. На лондонських імперських картах британські колонії були переважно рожево-червоними, французькі пурпурово-голубими, голландські жовто-брунатними тощо. Пофарбовані таким чином, колонії виглядали, мов окремі частинки дитячої складанки. Коли всі призвичаїлись до цього ефекту "складанки", кожну "частинку" можна було вже повністю виривати з її географічного контексту. Врешті-решт з неї можна було позабирати й усі пояснювальні елементи: паралелі й меридіани, назви місцевостей, позначення річок, морів і гір, сусідів. Чистий знак замість компасу для мандрів по світу. У цьому вигляді карту можна було нескінченно репродукувати й переносити на плакати, офіційні печатки, фірмові бланки, обкладинки журналів і підручників, скатертини й готельні стіни. Відразу впізнавана, скрізь присутня картаемблема глибоко проникла в народну уяву, ставши потужним символом антиколоніальних націоналістичних рухів, що саме народжувалися ${ }^{22}$.

ними картами, географічні реалії перестають бути елементами сучасності, а відсуваються на понад тисячу років у минуле. Історичні карти таким чином допомагають відкинути будь-які припушення про виникнення національної державності щойно в недавньому минулому, як і погляд, що сучасний Сіам виник у результаті розбрату. Відкидається також і думка, що Сіам народжено внаслідок взаємодії між європейськими державами $і$ Сіамом".

${ }^{21}$ Це засвоювання в жодному разі не було мак'явеллівськими хитрощами. Свідомість перших напіоналістів з усіх колоній Південно-Східної Азії була грунтовно сформована "характером" колоніальної держави та її інституцій. Див. вище VII розділ.

${ }^{22}$ У творах Ніка Хоакіна, нашого сучасника-філіппінця, видатного літератора - та безперечного патріота - можна побачити, як потужньо впливав цей символ на найвитонченіший інтелект. Хоакін пише про генерала Антоніо Луну, трагічного героя антиамериканських змагань 1898- 


\section{УЯВЛЕНІ СПІЛЬНОТИ}

Сучасна Індонезія дає нам чудовий, разючий приклад такого процесу. 1828 року було засноване перше голландське поселення на острові Нова Гвінея. Хоча поселення довелося залишити 1836 року, голландський престол проголосив свій суверенітет над тією частиною острова, що лежала на захід від 141 градусу широти (невидимої лінії, яка не співвідносилась ні з чим на поверхні землі, але обмежувала білі плями на карті), за винятком деяких берегових ділянок, які нібито перебували під суверенітетом султана острова Тідоре. Лише 1901 року Гаага викупила ці ділянки в султана й приєднала Західну Нову Гвінею до Голландської Індії - вчасно якраз для емблематизації. Великі частини регіону залишалися білими плямами аж до завершення Другої світової війни; жменьку голландців там складали здебільшого місіонери, розвідувачі мінералів - і наглядачі спеціальних в'язницьтаборів для незламних радикальних індонезійських націоналістів. Болота на північ від Мерауке, з південно-східного краю Голландської Нової Гвінеї, були обрані місцем для цих споруд саме тому, що цей регіон вважався найвіддаленішим від решти колонії, а місцеве населення доби “кам'яного віку" видавалося цілком захищеним від націоналістичних ідей ${ }^{-3}$.

Інтернування, або й нерідко поховання там націоналістичних страдників, поставило Західну Нову Гвінею на центральне місце в фольклорі антиколоніальної боротьби, перетворивши її на святиню національного уявлювання: Вільна Індонезія, від Сабангу (на північно-західному кінчику Суматри) до - чого ж іще, як не? - Мерауке. Не мало жодного

1899 років, який поспішав "виконати місію, до якої підсвідомо прагнули креоли вже протягом трьох століть: вберегти Філіппіни $y$ своїй формі від чужинця-руйнівника". A Question of Heroes, p. 164 (курсив наш). В іншому місці він, як це не дивно, зазначає, що іспанські “союзники-філіппінці, новонавернені й найманці, відіслані для боротьби з філіппінцями бунтівниками, хоча й робили архіпелаг іспанським і християнським, але також утримували його від розпаду"; та що вони “боролися (які б там не були наміри іспанців) за цілісність Філіппін”. Ibid., p. 58.

${ }^{23}$ Див.: Robin Osborne. Indonesia's Secret War, The Guerrilla Struggle in Irian Jaya, pp. 8-9. 
значення, що крім кількох сот інтерпованих, ніхто з націоналістів навіть не бачив на власні очі Нову Гвінею аж до 1960-х років. Але голландські колоніальні емблеми, поширювані в колонії, зображали Західну Нову Гвінею, на схід від якої не було нічого, несвідомо підсилюючи наростаючі уявні зв'язки. Коли в результаті жорстоких антиколоніальних війн 1945-1949-х років голландці були змушені віддати суверенітет над архіпелагом Сполученим Штатам Індонезії, вони спробували (з причин, на яких ми тут не зупинятимемося) ще раз відокремити Західну Нову Гвінею, утримати її тимчасово під колоніальним правлінням й готувати до самостійної національної державності. Лише 1963 року цю справу було залишено внаслідок потужного американського дипломатичного тиску й індонезійських військових рейдів. Щойно тоді президент Сукарно вперше, у шістдесятдвохрічному віці, відвідав-таки регіон, про який він невтомно промовляв протягом чотирьох десятиріч. Наступні болісні відносини між населенням Західної Нової Гвінеї й емісарами незалежної індонезійської держави можна пояснити тим фактом, що індонезійці більш-менш щиросердечно ставилися до цих народностей, як до “братів і сестер", тоді як самі народності бачили речі у зовсім відмінному світлі ${ }^{24}$.

Ця відмінність виникла великою мірою завдяки перепису й карті. Віддаленість Нової Гвінеї й неоднорідність її місцевості створили протягом тисячоліть надзвичайну мовну роздрібленість. Залишаючи регіон 1963 року, голландці під-

${ }^{24}$ Після 1963 року сталося багато кривавих епізодів у Західній Новій Гвінеї (відомій тепер під назвою Irian Јауа - Великий Іріан), частково в результаті мілітаризації індонезійської держави від 1965 року, частково завдяки успішній партизанській діяльності так званої ОРМ (Організації за Вільне Папуа). Але всі ці брутальності бліднуть порівняно з варварськими діями Джакарти у Східному Тиморі, де протягом перших трьох років після вторгнення 1976 року приблизно третина населення, шо налічувало 600,000 осіб, загинула від війни, голоду, хвороб і “переселень”. Не думаю, що помилковим було б припустити частинне походження цієї відмінності в тому, шо Східний Тимор був відсутній на логотипі Голландської Східної Індії та, до 1976 року, Індонезії. 


\section{УЯВЛЕНІ СПІЛЬНОТИ}

рахували, що серед 700,000 населення налічувалось понад 200 здебільшого взаємно незрозумілих мов ${ }^{-5}$. Багато які 3 віддалених "племінних" груп навіть не здогадувалися про існування одне одного. Проте, особливо після 1950 року, голландські місіонери й чиновники вперше почали здійснювати серйозні зусилля для їхнього “об’єднання”, проводячи переписи, розширюючи комунікаційну мережу, відкриваючи школи й вибудовуючи понад-“племінні" урядові структури. Ці зусилля заохочувались колоніальною державою, котра, як зазначалося нами раніше, була унікальною в тому розумінні, що правила Східною Індією за посередництвом не якоїсь європейської, а “адміністративної малайської" мови ". Отже Західна Нова Гвінея була "вихована" на тій самій мові, що й раніше Індонезія (ця мова стала згодом національною). Іронія полягає в тому, що таким чином bahasa Indonesia перетворилась у lingua franca західноновогвінейського, західнопапуаського націоналізму" .

Що єднало часто ворогуючих молодих західнопапуаських націоналістів, особливо після 1963 року, так це карта. Хоч індонезійська держава й змінила назву регіону з West Nieuw Guinea на Irian Barat (Західний Іріан), а згодом на Irian Jaya, вона сприймала його локальну географії з перспективи пташиного польоту атласу колоніальної доби. Нечисленні антропологи, місіонери й місцеві чиновники могли знати й пам'ятати про ндані, асматів і бауді. Проте сама держава, а завдяки їй індонезійське населення в цілому, бачили тільки примарних "іріанців" (orang Irian), названих так згідно з картою; а раз примарних, то й уявлених у вигляді напівемблеми: "негроїдні" риси, піхви для пенісу й таке інше. Це трохи нагадує нам, як вперше в межах расистської структури Голландської Східної Індії початку ХХ ст. почав формуватися

\footnotetext{
${ }^{25}$ Osborne. Indonesia's Secret War, p. 2.

${ }_{27}^{26}$ Див. вище VI розділ.

${ }^{27}$ Найкрашим свідченням цього $€$ назва антиіндонезійської націоналістичної партизанської організації "Organisasi Papua Merdeka” (OPM), шо складається з індонезійських слів.
} 
образ Індонезії і з'явився ембріон “іріанської" піціональної спільноти, обмеженої 141-м меридіаном та сусідиіми провінціями Північних і Південних Молуккських островів. В той час, коли їі найвизначнішого й найпривабливіного речника, Арнольда Апа, було замордовано 1984 року де)жавою, він працював куратором створеного державою музею, що займався “іріанською” (провінційною) культурою.

\section{Музей}

Зв'язок між професією Апа та його вбивством не випадковий. Адже музеї й омузеювальне уявлювання стають по суті політичними феноменами. Те, що музей Апа було засновано далекою Джакартою, демонструс, як нова національна держава Індонезія вчилася від свого найближчого попередника, колоніальної Голландської Східної Індії. Сучасне поширення музеїв по всій Південно-Східній Азії свідчить про дію загального процесу політичного успадкування. Будьяке намагання зрозуміти цей процес вимагає розгляду новітньої колоніальної археології ХІХ ст., яка зробила можливим виникнення таких музеїв.

До самого початку XIX ст. колоніальні правителі Південно-Східної Азії виявляли дуже малу зацікавленість до стародавніх пам'яток підлеглих їм цивілізацій. Томас Стемфорд Рафлз, зловісний емісар Калькутти Вільяма Джонса, був першим визначним колоніальним чиновником, котрий не просто зібрав велику особисту колекцію місцевих objets d'art, але й систематично досліджував їхню історію ${ }^{28}$. Відтоді, 3 наростаючою швидкістю, величні залишки Боробудуру, Ангкору, Пагану й інших древніх пам'яток були послідовно розкопані, розчищені, виміряні, сфотографовані, реконстру-

${ }^{28} 1811$ року збройні сили Східноіндійської Компанії захопили всі володіння Голландської Індії (за рік до цього Наполеон прилучив Нідерланди до Франції). Рафлз правив на Яві до 1815 року. Його монументальна “Історія Яви" з'явилася 1817 року, за два роки до заснування ним Сiнгапуру. 
йовані, обгороджені, проаналізовані й виставлені напоказ ${ }^{29}$. Колоніальні Археологічні Служби стали впливовими й престижними закладами, які залучали часом до праці надзвичайно здібних чиновників-науковців ${ }^{30}$.

${ }^{29}$ Прикладом цього процесу є перетворення в музей Боробудура, найбільшої в світі буддистської ступи. В 1814 році їі “відкрив" і розчистив від джунглів режим Рафлза. В 1845 році авантюрний німецький художник Шефер переконав голландський уряд в Батавії оплатити йому виконання перших дагеротипів. В 1851 році Батавія направила групу державних службовців на чолі з цивільним інженером Ф. К. Вільсеном для систематичного обстеження барельєфів та виконання цілісної, “наукової" серії літографій. В 1874 році директор лейденського Музею старожитностей доктор К. Ліманс опублікував, згідно з розпорядженням міністра колоній, першу велику наукову монографію; він повністю покладався на літографії Вільсена, ніколи не відвідавши святиню особисто. В 1880-х роках професійний фотограф Сіфас виготовив детальний фотографічний огляд сучасного типу. В 1901 році колоніальний режим заснував Oudheidkundige Commissie (Комісію Старожитностей). Між 1907 і 1911 роками під наглядом Комісії було здійснено повну реставрацію ступи, виконану державним коштом групою під керівництвом цивільного інженера Ван Ерпа. Ймовірно, що на визнання пих досягнень Комісію було піднесено 1913 року до рівня Oudheidkundigen Dienst (Служби Старожитностей), яка утримувала монумент в належному вигляді до кінця колоніальної доби. Див.: C. Leemans. Boro-Boudour, pp. II-IV; and N. J. Krom. Inleiding tot de HindoeJavaansche Kunst, I, chapter 1.

${ }^{30}$ Королівський намісник Керзон (1899-1905), любитель старожитностей, котрий, як писав Гросльє, “наповнив життям" Археологічні дослідження Індії, сказав про це дуже добре: "Тут...однаковою мірою залишається нашим обов'язком як розкопувати й відкривати, класифікувати, репродукувати й описувати, копіювати й розшифровувати, так і плекати й оберігати". (Навіть Фуко не висловив би це краще). В 1899 році був заснований Археологічний Департамент Бірми - тоді ше частини Британської Індії - який невдовзі розпочав реставрацію Пагану. Попереднього року в Сайгоні відкрилася Ecole Française d'Extreше-Orient, a слідом за нею майже відразу Директорат Музеїв та Історичних Пам'яток Індокитаю. Негайно після того, як 1907 року французами було відлучено від Сіаму Сіемреап і Баттамбанг, було засновано Ангкорський Заповідник з метою “керзонізувати” найвеличніші древні пам'ятки Південно-Східної Азії. Див.: Bernard Philippe Groslier. Indochina, pp. 155-157, 174-177. Як зазначалося раніше, голландська колоніальна Комісія Старожитностей була заснована 1901 року. Такий збіг у роках - 1899, 1898, 1901 - демонструє не тільки прискіпливість, з якою конкуруючі колоніальні дер- 


\section{ПЕРЕПИС, КАРТА, МУЗЕЙ}

Щоб повністю дослідити, чому й коли це сталося, ми мали б відхилитися задалеко вбік. Достатньо буде, мабуть, сказати про те, що ця зміна пов'язана із занепадом торговоколоніальних режимів двох великих Ост-Індських Компаній та піднесенням справжньої модерної колонії, напряму поєднаної з метрополією. ${ }^{31}$. Престиж колоніальної держави тепер, відповідно, був тісно пов'язаний з престижем господаря її земель. Досить помітно, як археологічні зусилля великою мірою зосередились на реставрації імпозантних пам'яток ( і як ці пам'ятки заносились на карти, призначені для громадського розповсюдження й вивчення: проводився такий собі некрологічний перепис). Немає сумніву, що не обійшлося тут без впливу моди орієнталізму. Проте солідність інвестованих капіталів дозволяє підозрювати, що в держави були на те свої власні, ненаукові причини. Можна відразу ж назвати три такі причини, остання з яких є, безперечно, найсуттєвішою.

Перш за все, початок археологічного прориву хронологічно співпав із першими спробами політичної боротьби за освітній курс держави

жави стежили одна за одною, але й велетенські зміни, шо відбувалися з імперіалізмом на зламі століть. Як і можна було сподіватися, незалежний Сіам рухався дешо повільніше. Його Археологічна Служба відкрилася лише 1924, а Національний Музей 1926 року. Див.: Charles Higham. The Archaeology of Mainland Southeast Asia, p. 25.

В 1799 році, збанкрутувавши, була ліквідована VOC. Колонія Голландської Індії бере, однак, свій початок від 1815 року, коли Священний Союз відновив незалежність Нідерландів, а Вільгельм I Оранський сів на голландський престол, вигаданий вперше в 1806 році Наполеоном і його любим братом Людовиком. Британська Ост-Індська Компанія протривала до великого індійського Повстання 1857 року.

Oudheidkundige Commissie була заснована тим самим урядом, який (1901 року) започаткував нову "Етичну Політику" Голландської Індії, політику, шо вперше була спрямована на запровадження освітньої системи західного типу для значної кількості колонізованих осіб. Генерал-губернатор Пол Думер (1897-1902) створив як Директорат Музеїв та Історичних Пам'яток Індокитаю, так і модерний освітній апарат колонії. Різке поширення вишої освіти в Бірмі - де між 1900 і 1940 роками кількість учнів середніх шкіл зросла увосьмеро, з 27,401 до 233,543, а студентів ко- 
"Прогресисти" - як колоністи, так і тубільці - домагалися серйозних інвестицій в сучасну освіту. Проти них виступали консерватори, котрі остерігалися довгострокових наслідків такої освіти й воліли, щоб тубільці залишалися тубільцями. В цьому світлі реставрації археологічних пам'яток - слідом за якими невдовзі з'явилися спонсоровані державою друковані видання традиційних літературних текстів - можуть розглядатися як свого роду консервативні освітні програми, які також служили претекстом для протидії тиску прогресистів. По-друге, формальна ідеологічна реконструкційна програма завжди вибудовувала певну ієрархію між будівниками монументів і колоніальними тубільцями. В деяких випадках, як-от у Голландській Східній Індії аж до 1930-х років, виношувалась ідея, що будівничі не були, фактично, однієї й тієї ж "раси” з тубільцями (а були "насправді" індійськими іммігрантами) ${ }^{3}$. В інших випадках, як у Бірмі, поширювались уявлення про поступовий занепад, в результаті чого теперішні тубільці вже не спроможні повторити досягнення своїх імовірних предків. В такому разі, реконструйовані монументи, виділяючись на фоні навколишньої сільської злиденності, ніби доводили до відома тубільців - вже одна наша присутність демонструє, що ви або були завжди, або давно стали нездатними творити величні справи чи здійснювати самоврядування.

Третя причина має глибші корені й тісніше пов'язана 3 картою. Ми вже звертали увагу раніше, при обговоренні "історичної карти", на те, як з цілком відвертих макіявеллівсько-легалістичних міркувань колоніальні режими починали надавати старовині не меншого значення, ніж завоюванню. 3 бігом часу, однак, все менше говорили про брутальне

леджів удвадцятеро, 3115 до 2,365 - розпочалось якраз тоді, коли активно запрацював Археологічний Департамент Бірми. Див.: Robert H. Taylor. The State in Burma, p. 114.

${ }^{33}$ Знаходячись частково під впливом подібних ідей, консервативні таїландські інтелектуали, археологи й чиновники до цього часу наполегливо приписують Ангкор загадковому Кхому, котрий безслідно зник і не має, безперечно, нічого спільного з нікчемними сучасними камбоджійцями. 
право на підкорення й усе більше зусиль ('п)ямовували на створення альтернативної легітимності. В Південно-Східній Азії народжувалось усе більше європейціз, котрі вважали їі своїм рідним домом. Археологія, дедалі тісніше пов'язана 3 туризмом, давала державі змогу виступати в ролі хранителя традиції загалом і місцевої традиції зокрема. Старі сакральні місцевості залучались до карти колонії, а їхній стародавній престиж (який, навіть занепавши, як це часто траплялося, відроджувався завдяки зусиллям держави) надавав значення роботі картографів. Цю парадоксальну ситуацію добре ілюструє той факт, що довкола реконструйованих пам'яток часто з'являлися старанно розплановані галявини, де тут і там були розкидані неодмінні пояснювальні дощечки з датами. Більше того, тут не мало бути людей, за винятком відвідувачів-туристів (по можливості, жодних релігійних церемоній чи паломництв). Омузеєні таким чином, вони зберігались як регалії секулярної колоніальної держави.

Проте, як зазначалося раніше, характерним інструментом цієї світської держави було безперервне репродукування, технічно можливе завдяки друку й фотографії, а політичнокультурно в силу того, що самі правителі не вірили в істинну сакральність місцевих святинь. Скрізь помітна певна послідовність: (1) солідні, технічно довершені археологічні звіти, доповнені десятками фотознімків, що відтворюють процес реконструкції окремих, вибраних руїн; (2) розкішно ілюстровані книжки для громадського споживання з обов' язковими зображеннями всіх головних святинь, реконструйованих у межах колонії (найкраще, коли, як у Голландській Індії, індобуддистські храми можуть бути поставлені поруч із реставрованими мусульманськими мечетями) ${ }^{-3}$. Завдяки капіталіс-

\footnotetext{
${ }^{34}$ Чудовим прикладом є запізніле видання "Старовинного Індонезійського Мистеитва", виконане голландським дослідником А. Дж. Бернетом Кемперсом, який сам себе називає "колишнім директором археології в Індонезії [sic]". На сторінках 24-25 знаходяться карти, на яких вказані місця розташувань древніх святинь. Перша з них особливо цікава тим, шо своєю прямокутною формою (обмеженою зі сходу 141-м меридіаном) 


\section{УЯВЛЕНІ СПІЛЬНОТИ}

тичному друкарству підданим держави став доступний, хай і за високу ціну, такий собі ілюстрований перепис вотчинного майна держави; (3) загальна емблематизація, що стала можливою в результаті окреслених вище процесів. Поштові марки, з характерними для них серіями - тропічні птахи, фрукти, фауна, а чому 6 і не монументи? - є типовим явищем цієї стадії. Але поштові листівки і шкільні підручники підкоряються тій самій логіці. Звідси лишається тільки один крок до ринку: Готель "Паган", Borobudur fried chickeп й таке інше.

Хоча подібна археологія, що визрівала у добу механічного репродукування, була політизованою, ця політизація відбувалась на такому глибинному рівні, що майже ніхто, включаючи жителів колоніальної держави (серед яких у 1930-х роках у більшій частині Південно-Східної Азії 90\% складали тубільці), не усвідомлював цього факту. Вона стала частиною буденного життя. Справжня сила держави виявлялася саме в безперервному повсякденному репродукуванні ії регалій.

Немає, мабуть, нічого дивного в тому, що пост-колоніальні держави, під очевидним впливом традицій своїх колоніальних попередників, успадкували цю форму політичного омузеювлення. Наприклад, 9 листопада 1968 року, в ході святкувань на відзначення 15-ої річниці камбоджійської незалежності, Нородом Сіанук виставив на національному стадіоні в Пномпені виготовлену з дерева й пап'є-маше велику копію славетного ангкорського храму Байон ${ }^{3.5}$. Копія була неймовірно грубою й незграбною, але вона виконувала своє завдання - завдяки емблематизованій історії колоніальної доби негайно розпізнавалась. "Ах, наш Байон” - без жодних згадок про французьких колоніальних реставраторів. Реконструйований французами Angkor Wat [ангкорський храм],

мимоволі охоплює Філіппінське Мінданао, а також британсько-малайське північне Борнео, Малайський півострів і Сінгапур. Там немає вказівок ні жодні святині, фактично, навіть немає назв, якшо не рахувати єдиного, незрозумілого позначення "Кедаг". Перехід від індо-буддизму до ісламу відбувається після ілюстрації № 340.

${ }^{35}$ Див.: Kambuja, 45 (15 December 1968), де є декілька курйозних фотографій. 
знов у вигляді “складанки”, став, як зазначалося в IX розділі, центральним символом прапорів цілого ряду режимів - роялістського Сіанука, мілітаристського Лон Нола та якобинського Пол Пота.

Ще разючішим є свідчення спадкоємності на більш масовому рівні. Одним із таких показових прикладів є серії картин, що відтворюють різні епізоди національної історії, замовлені в 1950-х роках міністерством освіти Індонезії. Картини призначались для масового виготовлення й розповсюдження через систему початкових шкіл; молоді індонезійці повинні були бачити на стінах своїх класів - скрізь візуальні образи минулого своєї країни. В цілому вони всі були зроблені в очікуваному сентиментально-натуралістичному стилі комерційного мистецтва початку XX ст., а людські постаті переносились або з музейних діарам колоніальної доби, або з популярного псевдоісторичного фольклорного театру тіней жаyang orang. Однак, найцікавіша з серій представляє дітям зображення Боробудура. В реальності цей колосальний монумент, який налічує 504 образи Буди, 1,460 ілюстративних і 1,212 декоративних кам'яних плит, є феноменальною скарбницею древньої яванської скульптури. Але шановний митець уявляє це чудо IX ст. досить своєрідно. Боробудур намальовано цілковито білою фарбою без жодного сліду будь-яких скульптур. Він оточений акуратно підстриженими газонами й охайними алейками, де з усіх боків ростуть дерева, й нідене видножодної людини ${ }^{36}$. Можна сперечатися, чи ця порожнеча віддзеркалює ніяковість сучасного художника-мусульманина перед лицем стародавньої буддистської дійсності. Але я підозрюю, що перед нами насправді постає, так би мовити, неусвідомлений прямий нащадок колоніальної археології: Боробудур як державна регалія та, “звісно ж”, емблема. Тим потужніша ознака національної ідентичності, що у свідомості усіх знаходиться в нескінченному ряді тотожних Боробудурів.

\footnotetext{
${ }^{36}$ Докладніше цей матеріал проаналізовано в моїй праці "Language and Power', chapter 5.
} 
Взаємопов'язані, таким чином, одне з одним, перепис, карта й музей висвітлюють спосіб мислення пізньої колоніальної держави про свої володіння. "Основою” такого мислення була узагальнююча класифікаторська сітка, яку з неймовірною гнучкістю можна було достосовувати до будьчого, що підлягало дійсному або сподіваному державному контролю: до людей, регіонів, релігій, мов, товарів, монументів тощо. Ефективність такої сітки полягала в її властивості завжди сказати, що щось $є$ тим, а не іншим; воно належить тут, а не там. Все це було обмеженим, чітко визначеним, а отже - в принципі - обчислюваним. (Кумедні класифікаційні категорії й підкатегорії перепису під назвою "Інші" пропонували замість реальних життєвих аномалій чудовий бюрократичний trompe l'oeil [натюрморт]). Ниткою цієї тканини можна було 6 вважати серіалізацію: припущення, що весь світ складається з безлічі тотожних копій. Кожна окрема одиниця була частиною умовного ряду й вимагала до себе відповідного ставлення. Ось чому колоніальна держава спочатку уявляла загальний ряд китайців, а тільки потім окремого китайця, так само як націоналістичний ряд поставав в її уяві раніше від появи будь-яких націоналістів.

Ніхто не знайшов кращої метафори для такого способу думання, як видатний індонезійський романіст Прамоедья Ананта Тоер, який назвав останню частину своєї тетралогії з колоніальної доби "Ruman Каса" - "Скляний будинок". Це образ тотального нагляду, не менш потужний, ніж паноптикум Бентама. Адже колоніальна держава не просто прагнула створити під своїм контролем панораму людського суспільства, видимого з усіх боків; умовою цієї “видимості” було те, щоб усі й усе мали на собі (так би мовити) серійний номер ${ }^{37}$. Подібного роду уявлення не виникло з нічого. Воно було продуктом таких наук і технологій, як навігація, астрономія,

\footnotetext{
${ }^{37}$ Показовим політичним наслідком всього уявленого в “Скляному будинку" - наслідком, болісно усвідомленим колишнім політичним в'язнем Прамоедьєю - є ідентифікаційна картка, яку тепер мусять завжди
} 
годинникарство, топографія, фотографія й друкарство, вже не кажучи про потужну рушійну силу капіталізму.

Таким чином карта й перепис сформували основи словника, завдяки якому поступово стала можливою поява "Бірми” й “бірманців", “Індонезії” й “індонезійців”. Але конкретизація цих потенцій - втілення якої існують нині своїм повноцінним життям, тоді як колоніальна держава давно вже зникла - завдячує великою мірою специфічному уявлюванню колоніальною державою історії й влади. Археологія була неймовірною річчю в доколоніальній Південно-Східній Азії; в неколонізованому Сіамі нею почали займатися досить пізно, перейнявши, до того ж, стиль колоніальної держави. Вона сприяла створенню серій “стародавніх пам'яток”, поділених на окремі сегменти в межах класифікаційних, географічнодемографічних категорій "Голландська Індія" й “Британська Бірма". Задумані як складові частини цих світських колекцій, руїни виявлялися доступними для нагляду й нескінченного копіювання. Задяки тому, що археологічна служба колоніальної держави технічно уможливила складання цих зібрань у картографічній та зафіксованій у фотознімках формі, держава змогла вважати їх історичними альбомами своїх предків. Суть справи ніколи не полягала в специфічному Боробудурі чи окремому Пагані, до яких держава не виявляла особливого інтересу і з якими вона була пов'язана лише археологічно. Відтворювані серії, однак, створювали історичну перспективу, яка легко успадковувалася постколоніальними наступниками держави. Кінцевим логічним наслідком стала емблема - "Пагану" чи "Філіппін", це вже не грало ролі - яка у силу своєї порожнечі, відсутності контексту, візуального запам'ятовування й здатності до необмеженого репродукування привела перепис і карту, нитку й основу, до нерозділимого єднання.

носити з собою всі дорослі індонезійці. Ця картка певною мірою тотожна до перепису - вона $є$ чимось типу політичного перепису, зі спеціальними штампами для тих, кого віднесли до підкатегорій "підривні елементи" й “зрадники”. Варто зазначити, що цей тип перепису лише вдосконалювався після здобуття національної незалежності. 


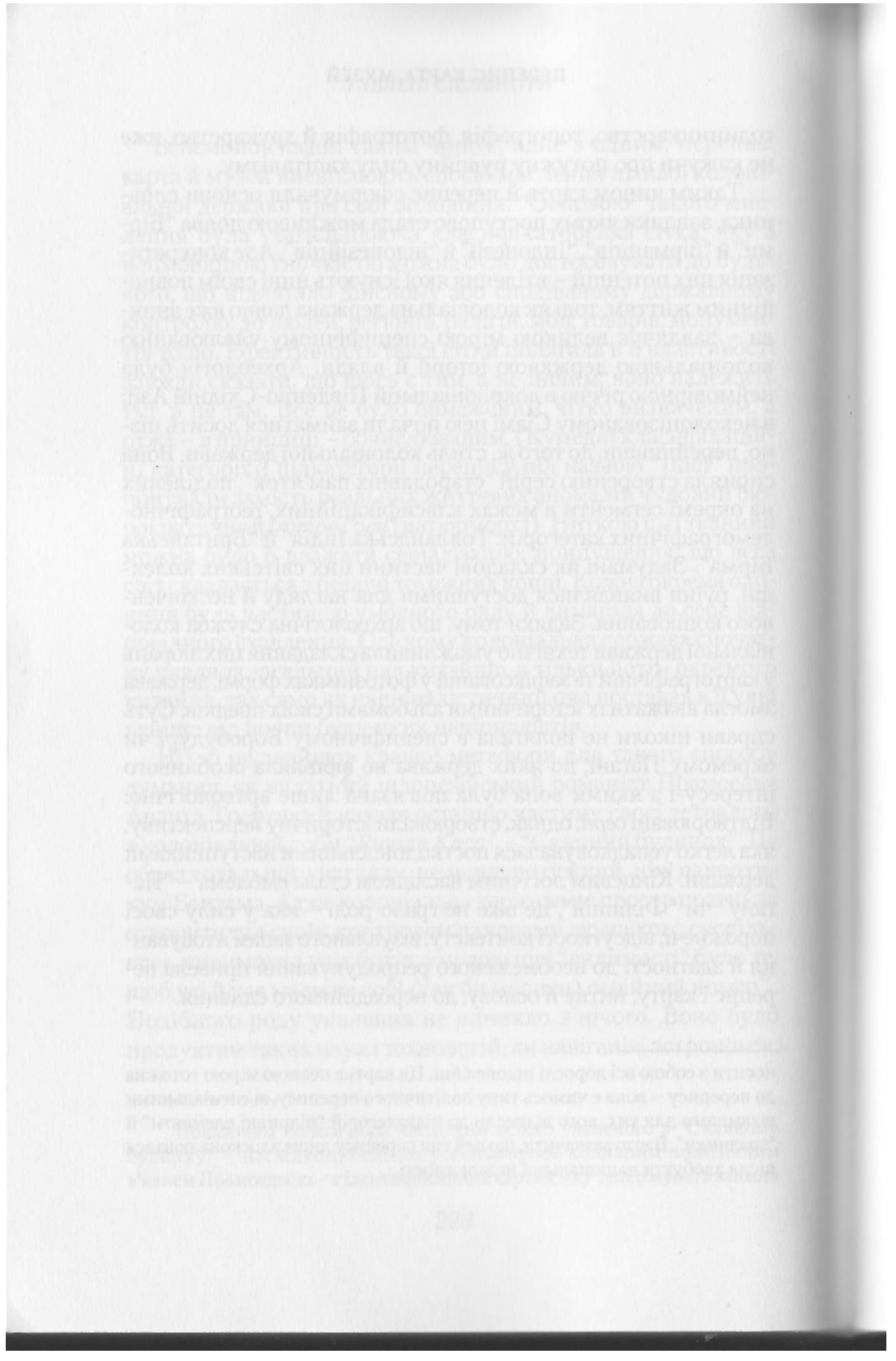




\section{Пам’ять і забуття}

\section{Простір новий і старий}

New York, Nueva Leon, Nouvelle Orleans, Nova Lisboa, Nieuw Amsterdam. Вже в XVI ст. європейці започаткували дивну звичку називати віддалені місця, насамперед у Америках і в Африці, а згодом в Азії, Австралії й Океанії, "новими” версіями "старих" топонімів з іх рідних земель. Більше того, ця традиція зберігалася навіть тоді, коли такі місця відходили до інших імперських володарів, отож Nouvelle Orleans спокійно nеретворювався в New Orleans, a Nieuw Zeeland y New Zealand.

Не можна сказати, що називання певних політичних $\mathrm{i}$ релігійних місцин "новими” було саме по собі чимось справді новим. У Південно-Східній Азії, приміром, можна зустріти досить древні міста, в назвах яких також є елементи новизни: Chiangmai (Новий Град), Kota Bahru (Нове Місто), Pekaпbaru (Новий Ринок). Але в цих назвах "новий" незмінно означав "наступника" або "спадкоємця" того, що зникло. "Новий” і “старий” поєднані діахронічно, причому цей “новий” завжди начебто отримує невиразне благословення мертвих. Що вражає в американських найменуваннях періоду з XVI по XVIII ст., це те, що "новий” і “старий" сприймалися синхронічно, співіснуючи в однорідному порожньому часі. 
Vizcaya існує одночасно із Nueva Vizcaya, Нью Лондон одночасно із Лондоном: це радше ідіома братського суперництва, ніж спадкоємства.

Подібна синхронна "новизна" могла історично виникнути лише тоді, коли значні групи людей почали усвідомлювати, що вони живуть паралельно з іншими великими групами людей - хоча й не зустрічаються ніколи, але рухаються, безперечно, однією траєкторією. Накопичення в період між 1500 і 1800 роками технологічних новинок у галузях суднобудування, навігації, годинникарства й картографії, доступних завдяки капіталістичному друкарству, робило можливим такий тип уявлювання . Ставало цілком імовірним мешкати на перуанському альтиплано, в аргентинській пампі чи біля гаваней "Нової" Англії, та водночас відчувати зв'язок 3 певними регіонами або спільнотами, шо знаходяться за тисячі миль у Англії чи на Іберійському півострові. Можна було абсолютно свідомо поділяти спільну мову й релігійну віру (різною мірою), звичаї й традиції, навіть не маючи великих сподівань на майбутню зустріч зі своїми партнерами".

Щоб це відчуття паралелізму або одночасності не просто з'явилося, але й мало серйозні політичні наслідки, було необхідно, щоб відстань між паралельними групами була

\footnotetext{
${ }^{1}$ Це накопичення сягнуло свого нестямного апогею під час "міжнародних" (тобто європейських) намагань знайти точний вимір географічної довготи, цікаву розповідь про що можна знайти в: Landes. Revolution in Time, chapter 9. В 1776 році, коли Тринадцять Колоній проголосили свог незалежність, "Gentleman's Magazine" помістив наступний коротенький некролог на смерть Джона Харрісона: “Він був найвинахідливішим механіком, який отримав нагороду в 20,000 фунтів стерлінгів [від англійського парламенту] за відкриття довготи [sic]".

${ }^{2} \in$ цікаве посилання на запізніле поширення такого типу свідомості в Азії на перших сторінках великого історичного роману Прамоедьї Ананти Тоера "Bumi Manusia" [Земля людства]. Молодий націоналіст, герой роману, розмірковує над тим, що він народився того самого дня, що й майбутня королева Вільгельміна - 31 серпня 1880 року. “Але коли мій острів загортався в темряву ночі, її країну пестило сонце; а коли її країна була охоплена нічною пітьмою, мій острів був осяяний проміннями екваторіального світила". Стор. 4.
} 
досить великою, а новіші з них були доволі численними й стали осілими i, крім того, міцно підпорядкованими старшим групам. Обидві Америки відповідали цим умовам якнайкраще. Перш за все, величезні розміри Атлантичного океану й цілком відмінна географічна ситуація на його протилежних краях унеможливлювали таке поступове поглинення населення більшими політико-культурними утвореннями, яке трансформувало Las Españas в Espana й затягнуло Шотландію до Сполученого Королівства. По-друге, як зазначалося в IV розділі, європейська міграція до Америк набула вражаючих масштабів. Наприкінці ХІХ ст. серед 16,900,000 мешканців Західної імперії іспанських Бурбонів налічувалось не менше 3,200,000 “білих" (включаючи не більш, як 150,000

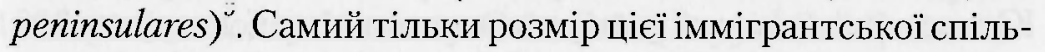
ноти, вже не кажучи про її переважаючу військову, економічну й технологічну силу порівняно з корінним населенням, забезпечував дотримання нею своєї культурної цілісності й збереження місцевого політичного панування ${ }^{4}$. По-третє, імперська метрополія мала в свосму розпорядженні величезний бюрократично-ідеологічний апарат, який давав їй змогу

\footnotetext{
${ }^{3}$ Зрозуміло, що "білі" являли собою легальну категорію, яка мала вельми поверхове відношення до складних соціальних процесів. Як говорив сам Визволитель, “Миє мерзенними нащадками хижаків-іспанців, котрі прибули до Америки, щоб висмоктати з неї кров і спаруватися зі своїми жертвами. Пізніше незаконні плоди таких союзів з'єдналися з нашадками рабів, привезених із Африки" (курсив наш). Lynch. The Spanish-American Revolutions, p. 249. Треба остерігатися від визнання чогось "відвічно європейського" в цьому criollismo. Пам'ятаючи всіх тих ревних сингало-буддистських Да Сузів, тих побожних флорино-католицьких Да Сільвів і тих цинічних манілено-католицьких Соріанів, котрі відігравали свої безсумнівні соціальні, економічні й політичні ролі в сучасних Цейлоні, Індонезії й Філіппінах, не так важко визнати, що в належних умовах європейці могли м'яко поглинатися неєвропейськими культурами.

Порівняймо долю численних представників африканської імміграції. Брутальний механізм рабства не просто забезпечував політично-культурну роздрібленість цього населення, але й дуже швидко усував навіть можливість уявлення руху паралельними траєкторіями чорних спільнот Венесуели й Західної Африки.
} 


\section{УЯВЛЕНІ СІІЛЬНОТИ}

протягом багатьох віків нав'язувати свою волю креолам. (Враховуючи самі лише транспортні проблеми, здатність Лондона й Мадрида вести тривалі антиреволюційні війни із бунтівними американськими колоністами справляють враження).

Новизна всіх цих обставин стає очевидною у порівнянні з великими (й більш-менш одночасними) китайськими й арабськими міграціями до Південно-Східної Азії й Східної Африки. Ці міграції рідко “планувалися" метрополією й ще рідше встановлювали стабільні відносини підлеглості. Стосовно Китаю, єдиною віддаленою паралеллю може служити вражаюча серія морських переходів через Індійський океан, які здійснив на початку XV ст. блискучий адмірал-євнух Чан-го. Ці сміливі експедиції, здійснені з наказу імператора Юн-ло, мали на меті утвердження монополії двору на зовнішню торгівлю з Південно-Східною Азією й західнішими регіонами, спрямовану проти хижацтва приватних китайських купців ${ }^{5}$. Вже в середині століття провал цієї політики став очевидним. Династія Мін облишила заморські авантюри й робила все від неї залежне, щоб зупинити еміграції з Серединної імперії. Завоювання Південного Китаю 1645 року Манчжурами спровокувало значну хвилю біженців до Південно-Східної Азії, для яких будь-які політичні зв'язки з новою династією були немислимі. Подальша політика династії Цін не особливо відрізнялася від курсу останніх Мінів. 1712 року, скажімо, указом імператора Кансі було заборонено всю торгівлю з Південно-Східною Азією й оголошено, що його уряд "вимагатиме в зарубіжних урядів репатріації всіх китайців, що опинилися за кордоном, з метою їхньої страти". Остання велика хвиля заморської міграції мала місце в XIX ст., коли розпадалася династія, а в колоніальній Південно-Східній Азії й Сіамі виник величезний попит на некваліфіковану китайську робочу силу. В силу того, що практично всі переселенці були політично відірвані від Пекіна й залишались також неписьменними людьми, що спілкувалися на взаємно

\footnotetext{
${ }^{5}$ Див.: О. W. Wolters. The Fall of Srivijaya in Malay History, Appendix C.

${ }^{6}$ Цитата 3: G. William Skinner. Chinese Society in Thailand, pp. 15-16.
} 
незрозумілих мовах, вони або поглиналися тією чи іншою мірою місцевими культурами, або рішуче підпорядковувались передовішим європейцям .

Щодо арабів, то більшість їніх міграцій започатковувалась у Хадрамауті, що ніколи не був справжньою метрополією епохи Османської й Могольської імперій. Підприємливі індивіди могли знаходити шляхи для заснування місцевих князівств, так як це сталося з купцем, що заклав 1772 року королівство Понтіанак у західному Борнео; але він одружився 3 місцевою, невдовзі втратив свою “арабкість”, якщо не мусульманство взагалі, й потрапив у залежність до набираючих вагу в Південно-Східній Азії голландської й англійської імперій, а не до котроїсь держави Близького Сходу. В 1832 році володар Маскату Саїд Саїд [Sayyid Sa'id] заклав на східноафриканському узбережжі могутній опорний пункт і поселився на острові Занзібар, зробивши його центром процвітаючого господарства по вирощуванню гвоздики. Проте британці використали військову силу, щоб змусити його розірвати зв'язки з Маскатом. Таким чином ані араби, ні китайці, що вирушали у великі заморські подорожі приблизно одночасно із європейцями, не спромоглися заснувати цілісні, заможні, свідомо креольські спільноти, підпорядковані великому метропольному центру. Відповідно, на світі ніколи не з'явилися Нова Басра чи Новий Ухань.

"Подвійність" Америк і підстави для цього, окреслені вище, допомагають з'ясувати, чому націоналізм виник спочатку в Новому Світі, а не в Старому ${ }^{3}$. Вони також висвітлюють дві характерні риси революційних війн, що лютували в

\footnotetext{
7 Заморські китайські громади зростали настільки загрозливо, що збуджували глибоку європейську параною аж до середини XVIII ст., коли нарешті припинилися жорстокі антикитайські погроми, ініційовані прибульцями з Заходу. Відтоді цю потворну традицію було скеровано проти корінного населення.

${ }^{8}$ Див.: Marshall G. Hodgson. The Venture of Islam, Vol. 3, pp. 233-235.

${ }^{9}$ Вражаючою ознакою глибини євроцентризму є те, шо стільки європейських учених продовжують, незважаючи на жодні докази, вважати націоналізм європейським винаходом.
} 


\section{УЯВЛЕНІ СПІЛЬНОТИ}

Новому Світі між 1776 і 1825 роками. 3 одного боку, ніхто з креольських революціонерів не думав про те, щоб залишати імперію цілою й неушкодженою, лише переорганізувавши внутрішній розподіл влади, помінявщи попередні підлеглі стосунки шляхом переносу метрополії з Європи до Америки ${ }^{10}$. Інакше кажучи, мета полягала не в тому, щоб Новий Лондон замінив, скинув чи зруйнував Старий Лондон, а радше у збереженні й надалі їхнього паралельного існування. (Наскільки новим було таке мислення, можна побачити з історії старих занепадаючих імперій, де часто мріялося саме про заміну старого центру.) 3 іншого боку, хоча ці війни принесли багато страждань і відзначалися значним варварством, ставки, як це не дивно, були досить низькими. Ні в Північній, ні в Південній Америці креолам не треба було остерігатися фізичного винищення чи захоплення в рабство, як це ставалося з багатьма іншими народами, що потрапляли під прес європейського імперіалізму. Зрештою, вони були "білими", християнами й іспано- чи англо-мовними особами; вони також були необхідними посередниками для метрополій, якщо економічне процвітання Західних імперій мало й надалі контролюватися Європою. Відповідно, вони являли собою важливе позаєвропейське угрупування, яке було підпорядковане Свропі, але водночас не відчувало відчайдушного страху перед цією Європою. Революційні війни, якими б вони не були жорстокими, мали ту перевагу, що це були війни між родичами ${ }^{11}$. Цей родинний зв'язок давав гарантію

\footnotetext{
${ }^{10}$ Але зверніть увагу на іронізм ситуації з Бразилією. 1808 року король Жуан VI втік до Ріо-де-Жанейро, рятуючись від Наполеонівських армій. Хоча до 1811 року Веллінгтон уже вигнав французів, монарх-емігрант, остерігаючись республіканських заворушень вдома, залишався в Південній Америці до 1822 року, отож між 1808 і 1822 роками Ріо був центром світової імперії, шо простягалась до Анголи, Мозамбіку, Макао й Східного Тимору. Але правив цією імперією не американець, а європеєць.

${ }^{11}$ Саме це, поза сумнівом, дозволило Визволителю одного разу заявити, що негритянський, тобто рабський, бунт був би "в тисячу разів гірший від іспанської інвазії" (див. вище в IV розділі). Заколот рабів, досягши успіху, загрожував креолам фізичним винищенням.
} 
того, що після певного загострення стосунків знову поновляться тісні культурні, а деколи й політичні та економічні зв'язки між колишніми метрополіями й новими націями.

\section{Час новий і старий}

Якщо для креолів Нового Світу дивні топоніми, про які йшлося вище, образно засвідчували їню зростаючу здатність уявляти себе спільнотами, паралельними й порівнюваними до європейських спільнот, екстраординарні події останньої чверті XVIII ст. цілком несподівано надали цьому нововведенню абсолютно нового значення. Першою з цих подій, безумовно, стала Декларація незалежності (Тринадцяти Колоній) 1776 року й успішний військовий захист цієї декларації в наступні роки. Ця незалежність, яка до того ж була республікансъкою незалежністю, сприймалась як щось абсолютно безпрецедентне, та водночас, навіть на самому початку свого існування, як щось цілком обгрунтоване. Отож, коли історія дала венесуельським революціонерам шанс укласти 1811 року конституцію Першої Венесуельської Республіки, вони не побачили нічого раболіпного в тому, щоб дослівно запозичити частини Конституції Сполучених Штатів Америки '. Адже те, що було написане в Філадельфії, не виглядало у венесуельських очах чимось північноамериканським, а становило певну універсальну істину й цінність. Невдовзі після цього, в 1789 році, у відповідь на вибух у Новому Світі відбулось паралельно вулканічне виверження Французької революції в Старому Світі ${ }^{13}$.

Сьогодні важко відтворити в уяві обставини життя, за яких нація відчувалася чимось цілковито новим. Але тієі епохи було саме так. Декларація незалежності 1776 року не

\footnotetext{
${ }^{12}$ Див.: Mazur. Bolivar; p. 131.

${ }^{13}$ В свою чергу паралеллю Французької революції у Новому світі стало в 1791 році повстання Туссена Лувертюра, в результаті якого 1806 року колишніми рабами Гайті була створена друга незалежна республіка Західної півкулі.
} 


\section{УЯВЛЕНІ СПЈЛЬНОТИ}

містить жодних посилань на Христофора Колумба, острів Роуноук або перших англійських колоністів, так само як не висуває і жодного “історичного" виправдання незалежності на зразок старожитності американського народу. Як не дивно, американську націю, по суті, навіть не згадано. Швидко поширювалося передчуття того, що відбувається радикальний розрив із минулим - "раптова проломина в суцільній історичній стіні”. Ніщо не виявляє ці інтуїтивні настрої краще, ніж рішення, прийняте Конвентом Nationale 5 жовтня 1793 року про скасування старого християнського календаря й запровадження нової світової ери, Перший Рік якої відраховувався б від часу ліквідації ancien regime і проголошення Республіки 22 вересня 1792 року $^{14}$. (Жодна наступна революція не справляла підсвідомого відчуття такої новизни, не в останню чергу тому, що Французька революція завжди вважалася першою.)

Це глибинне передчуття новизни породило також і nuestra santa revolución, цей чудовий неологізм, вигаданий Хосе Марією Морелосом Павоном (котрий 1813 року проголосив Республіку Мексику) незадовго до його страти іспанцями ${ }^{15}$. 3 нього ж виріс і указ Сан Мартіна від 1821 року про те, що "в майбутнъому корінних мешканців не називатимуть індіанцями або тубільцями; всі вони є діти й громадяни Перу, тобто - перуанці". Це речення зробило з “індіанцями" й/ або "тубільцями" те, що Конвент в Парижі вчинив з християнським календарем - воно скасувало старі зганьблені найменування й запровадило цілком нову епоху. Таким чином, "перуанці" й "Рік Перший" риторично ознаменовували собою глибокий розрив з існуючим світом.

Проте справи не могли довго залипгатися в такому стані з тих самих причин, що перш за все й викликали це відчуття

\footnotetext{
${ }^{14}$ Молодий Вордсворт був у 1791-1792 роках у Парижі й пізніше написав у своій “Прелюдії” ці пам'ятні рядки:

Щасливий той, хто зустрічав світанок цей, А хто тоді був юний, раю смак пізнав!

(курсив наш).

${ }^{15}$ Lynch. The Spanish-American Revolutions, pp. 314-315.

${ }^{16}$ Як цитувалося вище в IV розділі.
} 
розриву. В останній чверті XVIII ст. одна тільки Британія щорічно виготовляла від 150,000 до 200,000 годинників, багато з яких ішло на експорт. По всій Європі їх виготовлялося щороку близько 500,000 екземплярів ${ }^{17}$. Періодичні публікації газет стали вже тоді невід'ємною рисою міської цивілізації. Це саме стосується й роману, з його ефектними можливостями зображення одночасних дій в однорідному порожньому часі“. Космічний рух часу, який надав смисл нашому синхронному трансокеанському буттю, все більше формував враження, що містить цілком земний, серійний образ соціальної причинності; і таке розуміння світу тепер все більше оволодівало західною уявою. Отож зрозуміло, чому менш ніж через два десятиліття після проголошення Першого Року було засновано перші академічні кафедри історії - 1810 року в Берлінському університеті, а 1812 в наполеонівській Сорбонні. Вже в другій чверті XIX ст. історію формально визнали науковою “дисципліною”, що мала свою розгалужену мережу професійних журналів ${ }^{19}$. Дуже швидко на зміну Року Першому прийшов рік 1792 A.D., а революційні розломи 1776 і 1789 років почали трактуватися як складові частини історичних серій, а отже як історичні прещеденти й моделі ${ }^{20}$.

${ }^{17}$ Landes. Revolution in Time, pp. 230-231, 442-443.

${ }^{18}$ Див. више II розділ.

${ }^{19}$ Див.: Hayden White. Metahistony: The Historical Imagination in NineteenthCentury Europe, pp. 135-143, де детально обговорюється ця трансформація.

${ }^{20}$ Проте A.D. набрало іншого сенсу. Перед розривом воно ше зберігало теологічну ауру, нехай і вельми крихку в просвічених колах, якою його наповнювала середньовічна латина. Anno Domini нагадувало про те вторгнення вічності в земний час, шо сталося у Вифлеємі. Після розриву, скоротившись до монограми A.D., воно стало в один ряд із (англійським) розмовним В.С., Перед Христом [Before Christ], шо охоплювало серійну космологічну історію (до якої вагомий вклад почала вносити нова наука геологія). Про те, яке глибоке провалля лежало між Anno Domini та A.D./ B.C., можна судити з того, що ані буддистський, апі ісламський світ навіть сьогодні не позначає уявлено будь-яку епоху як "Перед Гаутамою Буддою" чи "Перед Хіджрою". Обидва вони дають собі таку-сяку раду з чужою їм монограмою В.С. 


\section{УЯВЛЕНІ СПІЛЬНОТИ}

Відповідно для членів націоналістичних рухів, так би мовити, “другого покоління”, що виникали в Європі між 1815 і 1850 роками, й також для генерації, котра успадкувала незалежні національні держави американського континенту, вже неможливо було "упіймати перший легкоплинний чар натхнення" їніх революційних попередників. 3 різних причин і з різними наслідками ці дві групи розпочали, таким чином, процес генеалогічного прочитання націоналізму - як виразу історичної традиції серійної безперервності.

Нові націоналізми в Європі майже відразу почали уявляти себе в стані “пробудження зі сну", тоді як для обидвох Америк цей троп був цілком чужим. Вже в 1803 році (як ми зазначали в $\mathrm{V}$ розділі) молодий грецький націоналіст Адамантіос Кораес звертався до прихильної паризької аудиторії: "Bnерше [грецька] нація озирає жахливу картину свого невігластва й тріпотить, вимірюючи оком відстань, що відділяє її від предківської слави". Тут перед нами досконалий приклад переходу від Нового Часу до Старого. У слові "вперше" ще відлунюються розломи 1776 i 1789 років, проте зворушений погляд Кораеса звернений не вперед, до Сан Мартінового майбуття, а в благоговійному трепеті назад, до предківської слави. Мине небагато часу, й ця п'янка двозначність почне поступатися місцем модульному, "безупинному” пробудженню від хронологічно виміряного, позначеного монограмою A.D. сну: гарантованому поверненню до первісної суті.

Безумовно, популярності цього тропу сприяли багато різних елементів ${ }^{21}$. Я тут згадаю тільки два 3 них. Перш за все, подібний мовний зворот враховує те чуття паралелізму, яке сприяло народженню американських націоналізмів і яке, завдяки успіхові американських національних революцій, значно зміцнилося в Європі. Він ніби пояснював той ди-

\footnotetext{
${ }^{21}$ Навіть у 1951 році ерудований індонезійський соціаліст Лінтон Мулія Сіторус міг ще писати, шо: "кольорові народи міцно спали до самого кінця XIX ст., тоді як білі активно працювали в кожній галузі”. Sedjarah Pergerakan Indonesia [Історія індонезійського національного руху], p. 5.
} 
вовижний факт, що національні рухи виникли в цивілізованому Старому Світі явно пізніше, ніж у варварському Новому $^{2}$. Це пізнє пробудження, хоча й стимульоване здалеку, відкривало приховані під покровом епохального сну незліченні стародавні скарби. По-друге, такий троп забезпечував вирішальний метафоричний зв'язок між новими європейськими націоналізмами й мовою. Як зазначалося раніше, головні держави Європи XIX ст. були великими багатомовними утвореннями, кордони яких ніколи не збігалися з мовними спільнотами. Більшість освічених представників цих держав успадкували ще від середньовічної доби звичку сприймати певні мови - коли вже й не латинську, то французьку, англійську, іспанську чи німецьку - як мови цивілізовані. Заможні голландські бюргери XVIII ст. вдома розмовляли винятково французькою; німецька мова здебільшого культивувалася в західній частині царської імперії, не меншою мірою, ніж у “чеській” Богемії. До самого кінця XVIII ст. ніхто не сприймав ці мови приналежними до будьякої територіально визначеної групи. Але невдовзі після цього, з причин, окреслених у III розділі, "нецивілізовані" народні мови почали політично функціонувати в подібній ролі, що й Атлантичний океан раніше: тобто "відокремлюючи" підлеглі національні спільноти від давніх династичних держав. Враховуючи те, що на чолі більшості європейських масових національних рухів стояли освічені люди, які нерідко були непризвичаєні до вживання цих народних мов, потрібно було дати пояснення такій аномалії. Важко було знайти щось краще від “сну”, адже це давало можливість тій інтелігенції й буржуазії, що починала усвідомлювати себе чеською, мадярською або фінською, вважати своє вивчення чеської, мадярської або фінської мови, фольклору й музики "віднайденням" у глибині єства чогось давно знаного. (Більше того, коли починати думати про національність з точки

\footnotetext{
${ }^{22}$ Можна, мабуть, стверджувати, що ці революції, на думку європейців, стали першими справді важливими політичними подіями, що будь-коли відбувалися по той бік Атлантичного океану. 


\section{УЯВЛЕНІ СПЛЬНОТИ}

зору безперервності, мало що видається настільки глибоко закоріненим історично, як мови, які не мають жодних конкретних дат свого народження) ${ }^{2 \prime}$.

В Америках проблема полягала в іншому. 3 одного боку, до 1830 -х років національна незалежність майже скрізь була вже міжнародно визнаною. Таким чином, вона вже стала спадщиною i, як спадщина, була включена до генеалогічних серій. Проте не все з європейського інструментарію надавалося до використання. Мова ніколи не посідала центрального місця в американських національних рухах. Як ми пересвідчилися, саме завдяки спільній з метрополією мові (як також спільним релігії й культурі) стали можливими перші уявлення нації. Безперечно, існують цікаві приклади, так би мовити, ранньої роботи "європейської" думки. Скажімо, "Американський словник англійської мови" Ноа Вебстера 1828 року (тобто, “другого покоління") був створений із наміром офіційного схвалення американської мови, яка відрізнялася своїм походженням від англійської. В Парагваї єзуїтська традиція XVIII ст. вживати мову гуарані дозволила цілковито неіспанській “корінній” мові перетворитись у національну мову під час тривалої, ксенофобної диктатури Хосе Гаспара Родрігеса де Франсії (1814-1840). Але в цілому будьякі спроби надати національності історичну глибину мовними засобами наштовхувались на нездоланні перешкоди. Практично всі креоли були інституційно пов'язані (через школи, друковані матеріали, адміністративні звичаї тощо) радше $з$ європейськими, ніж із корінними американськими мовами. Будь-яке надмірне акцентування мовного походження загрожувало затьмаренню саме тієї “пам'яті про незалежність", яку було необхідно вберегти.

Вирішення, яке виявилося придатним як для Нового, так і для старого Світів, було знайдене в Історії, або, якщо точ-

\footnotetext{
${ }^{23}$ Проте, історична глибина не $є$ безмежною. В певному пункті англійська мова розчиняється в норманській французькій і англо-саксонській; французька в латинській і мові "німецьких" франків; і так далі. Згодом ми побачимо, як досягалася додаткова глибина.
} 
ніше, в Історії, представленій відповідним чином. Ми вже зазначали швидкість, з якою слідом за Роком Першим виникли історичні кафедри. Як зауважує Хейден Вайт, не менш вражаючим є те, що всі п'ятеро найвидатніших європейських історіографів народилися протягом чверті століття після того, як Конвентом було здійснено часовий розрив: Ранке в 1795 , Мішле в 1798, Токвіль у 1805 й Маркс та Буркгардт у 1818 році ${ }^{4}$. Мабуть, природньо, що з цих п'яти саме Мішле, самопризначений історик Революції, найчіткіше висловив народження національного уявлювання, адже він першим свідомо писав від імені померлих ${ }^{-3}$. Характерним $€$ наступний уривок:

Oui, chaque mort laisse un petit bien, sa memoire, et demande qu'on la soigne. Pour celui qui n'a pas d'amis, il faut que le magistrat y supplee. Car la loi, la justice, est plus sûre que toutes nos tendresses oublieuses, nos larmes si vite sechees. Cette magistrature, c'est l'Histoire. Et les morts sont, pour dire comme le Droit romain, ces miserabiles personae dont le magistrat doit se preoccuper. Jamais dans ma carriere je n'ai pas perdu de vue ce devoir de l'historien. J'ai donne a beacoup de morts trop oublies l'assistance dont moi-meme j'aurai besoin. Je les ai exhumes pour une seconde vie... Ils vivent maintenant avec nous qui nous sentons leurs parents, leurs amis. Ainsi se fait une famille, une cite commune entre les vivants et les morts ${ }^{26}$.

${ }^{24}$ Metahistory, p. 140. Гегель, народжений у 1770 році, був уже юнаком, коли вибухла революція, але його "Vorlesungen über die Philosophie der Weltgeschichte" була опублікована лише 1837 року, через шість років після смерті.

${ }^{25}$ White. Metahistory, p. 159.

${ }^{26}$ “Так, кожен небіжчик залишає шось по собі, свою пам'ять, вимагаючи, щоб ми подбали про неї. Якщо ж у нього немає друзів, їх має заступити суддя. Адже закон і справедливість є надійніпими від нашої короткочасної жалоби, від наших сліз, що так швидко висихають. Цей суддя - Історія. А померлі, як стверджує римське право, це ті нещасні, ким має опікуватися суддя. Ніколи протягом своєї кар'єри я не знехтував цим обов'язком історика. Багатьом померлим, котрих так часто забувають, я надав допомогу, якої потребуватиму й сам. Я їх ексгумував для другого життя... Тепер вони живуть із нами, немовби зі своїми батьками й друзями. Так твориться родина, спільнота мертвих і живих". 


\section{УЯВЛЕНІ СПІЛЬНОТИ}

Мішле скрізь уточнює, що ті, кого він воскрешав, у жодному разі не були випадковим нагромадженням забутих, анонімних небіжчиків. Вони були тими, чиї жертви впродовж Історії зробили можливими злам 1789 року й виникнення французької нації, навіть якщо вони самі не розуміли істинної суті свойх жертв. 1842 року він писав про цих померлих: "Il leur faut un Oedipe qui leur explique leur propre énigwe dont ils n'ont pas eu le sens, qui leur apprenne ce que voulaient dire leurs paroles, leurs actes, qu'ils n'ont pas compris"'

Це, мабуть, безпрецедентне формулювання. Мішле не тільки взяв на себе сміливість говорити від імені численних безіменних небіжчиків, але й авторитетно стверджував, ніби йому відомо, що вони “насправді" думали й “насправді" хотіли, адже самі вони цього “не розуміли". Відтепер мовчанка мертвих уже не була перешкодою для ексгумації найпотаємніших іхніх жадань.

В подібному ж дусі все більше й більше націоналістів “другого покоління" на американському континенті й деінде вчилися говорити "від імені" небіжчиків, з якими було неможливо або небажано встановлювати мовний контакт. Таке чревовіщання "навпаки" допомагало розчищати шлях для свідомоro indigenismo, особливо в Південній Америці. Крайній випадок: месиканці, що говорять іспанською "від імені" доколумбових "індіанських" цивілізацій, мов яких вони не розуміють ${ }^{28}$. Наскільки революційним був цей. тип ексгу-

Jules Michelet. Oeuvres Completes, XXI, p. 268, в передмові до II тому ("Jusqu'au 18е Brumaire") його незавершеної "Histoire du XIXe Siecle". Посилання на це джерело я знайшов у "Metahistory", але переклад, яким користався Вайт, є незадовільним.

${ }_{27}$ "Потрібен Едіп, який пояснив би ім власну таємницю, сенс якої їм не збагнути, який би витлумачив їм власні слова й учинки, значення яких ім не зрозуміти".

Цитата з: Roland Barthes, ed. Michelet parlui-meme, p. 92. Том "Oeuores Completes", в якому міститься ця цитата, ще не опублікований.

I навпаки, в усій Мексиці є тільки одна статуя Ернана Кортеса. Цей пам'ятник, обачно запроторений до найглухішого куточка Мехіко, був поставлений лише наприкінці 1970-х років одіозним режимом Хосе Лопеса Портільйо. 
мації, можна найчіткіше з'ясувати, порівнявши його з формулюванням Ферміна де Варгаса, процитованим у II розділі. Адже якщо Фермін ще бадьоро розмірковував про "викорінення" живих індіанців, чимало його політичних онуків стало одержимими ідеєю “пам'ятати” про них, а то й “говорити від їх імені", мабуть, саме тому, що на той час так грунтовно їх викорінили.

\section{Розрада братовбивства}

Вражає, що у своїх формулюваннях Мішле завжди зосереджує увагу на ексгумації людей і подій, яким загрожує забуття ${ }^{2}$. Він не відчував потреби розмірковувати над самим "забуванням". Але коли 1882 року - понад сторіччя після проголошення в Філадельфії Декларації незалежності й вісім років після смерті самого Мішле - Ренан опублікував свою працю "Qu'est-ce qu'une nation?", його цікавила власне потреба забуття. Зверніть, скажімо, знову свою увагу на формулювання, яке вже цитувалося раніше в I розділіi ${ }^{30}$ :

Or, l'essence d'une nation est que tous les individus aient beaucoup de choses en commun et aussi que tous aient oublie bien des choses... Tout citoyen français doit avoir oublie la Saint-

Barthélemy, les massacres du Midi an XIIIe siecle.

3 першого погляду ці два речення можна сприймати буквально $^{31}$. Проте варто на кілька хвилин замислитися, як

\footnotetext{
${ }^{29}$ Безперечно тому, що більшу частину свого життя він мусив терпіти легітимність реставрованої або сурогатної влади. Про його прихильність до 1789 року й до Франції зворушливо свідчить його відмова присягнути на вірність Луї Наполеону. Раптово втративши свою посаду Національного Архіваріуса, він прожив, фактично, в злиднях до самої смерті в 1874 році - достатньо довго, однак, шоб застати падіння блазня й реставрацію республіканських інституцій.

Ренан народився 1823 року, чверть століття після Мішле, й більшу частину своєї молодості прожив під час цинічного офіційно-націоналістичного режиму гонителя Мішле.

${ }^{31}$ Що, на жаль, я і зробив 1983 року.
} 


\section{УЯВЛЕНІ СІІЛЬНОТИ}

негайно проявляється вся їхня химерність. Скажімо, ми помічаємо, що Ренан зовсім не збирався пояснювати своїм читачам, що означають "la Saint-Barthelemy" або "les massacres du Midi aп XIIIe siecle". Але кому ж, як не “французам", відразу, так би мовити, було б зрозуміло, що "la Saint-Barthélemy" стосувалася лютого анти-гугенотського погрому, влаштованого 24 серпня 1572 року королем Карлом IX Валуа та його матір'ю-флорентійкою; а під “les massacres du Midi" малося на увазі винищення альбігойців у обширному регіоні між Піренеями й Південними Альпами, спровоковане Інокентієм III, одним із найгріховніших із довгого ряду гріховних пап? Нічого дивного Ренан не знаходить й у тому, що його читачі "пам'ятатимуть" про подіі, які сталися 300 й 600 років тому. Вражає, крім того, категоричний синтаксис слів dott avoir oublie (а не doit oublier) - "зобов'язаний був уже забути" - який у зловісному тоні податкових кодексів і рекрутських законів дає зрозуміти, шо остаточне "забування" давніх трагедій $\epsilon$ тепер першочерговим громадянським обов'язком. По суті, читачам Ренана пропонувалося “давно вже забути” те, що, згідно з його ж власними словами, вони мали б природньо пам'ятати!

Як можна збагнути цей парадокс? Почнемо з того зауваження, що франиузький іменник однини "la Saint-Barthélemу" відноситься як до вбивць, так і до вбитих - тобто, до тих католиків і протестантів, які спільно брали участь у нечестивій Священній Війні, що лютувала в центральній 1 північній Європі XVI ст., та які, безумовно, не думали про себе всіх разом як про "французів". Подібним чином, "різанина XIII ст. в Midi [на півдні Франціi]” розмиває образ неназваних жертв і убивць уже самою французькістю слова "Midi". Немає потреби нагадувати читачам, що більшість замордованих альбігойців говорили на провансальському чи каталонському діалектах, і що їхні вбивці прибули з різних частин Західної Свропи. В результаті такої тропологіі епізоди колосальних релігійних конфліктів середньовічноі й ранньомодерної Європи поставали у вигляді розрадливо братовбивчих війн між - ким же ще? - співвітчизникамифранцузами. Оскільки ми можемо бути впевненими, що 
переважна більшість французьких сучаспиків Рснана, фактично, ніколи б могла й не почути про "la Saint-Barthelemy" або "les massacres du Midi", ми починаємо усвідомлювати існування систематичної історіографічної кампанії, що ведеться державою переважно через державну шкільну систему для “нагадування" кожному юному французу чи француженці про серію стародавніх кровопролить, які тепер зареєстровані як "родинна історія”. “Забування” трагедій, про які необхідно постійно "нагадувати", стає характерним прийомом пізнішого вибудовування національних генеалогій. (Показово, що Ренан не веде мову про те, що кожен французький громадянин повинен “давно вже забути” Паризьку Комуну. В 1882 році ця пам'ять була ще надто реальною, а не міфічною, й досить болісною, щоб її так легко було б залучити до категорії "розрадливого братовбивства".)

Зрозуміло, що в усьому цьому не було й немає нічого специфічно французького. Велика педагогічна індустрія безперервно працює над тим, цоб зобов'язати юних американців пам'ятати/забувати ворожнечу 1861-1865-х років як велику “громадянську" війну між “братами”, а не між - як це короткий час було - двома суверенними національними державами. (Можна бути впевненим, однак, що в тому випадку, якби Конфедерація втримала свою незалежність, цю “громадянську війну” замінило б у пам'яті щось далеко не таке вже й братерське). Англійські підручники з історії пропонують курйозний образ великого Батька-Засновника, якого кожний школярик привчається величати Вільгельмом Завойовником. Того самого школярика ніхто не інформує про те, що Вільгельм не розмовляв англійською, та й не міг цього робити, оскільки англійської мови тоді ще просто не існувало; ніхто теж йому не пояснює “Завойовник чого?". Адже сьогодні єдиною розумною відповіддю була б “Завойовник Англії”, яка перетворила 6 древнього норманського розбійника на більш успішного попередника Наполеона й Гітлера. Отож “Завойовник” виконує роль еліпсису, подібно до "la Saint-Barthelemy", щоб нагадувати про те, що відразу ж необхідно забувати. Таким чином, норман Вільгельм і 
саксонець Гаральд зустрічаються на полі бою біля Гастінгсу якщо вже не як партнери до танцю, то принаймні як брати.

Але, звичайно, надто спрощено було б пояснювати ці давні розрадливі братовбивства лише холодним розрахунком державних функціонерів. На певному рівні вони віддзеркалюють істотну зміну, що відбувалася з уявою, зміну, яку держава ще майже не усвідомлювала й над якою мала, та й досі має, тільки мінімальний контроль. У 1930 -х роках люди різних національностей вирушили воювати на Іберійський півострів, тому що вважали його ареною вирішальноі сутички глобальних історичних сил і процесів. Коли довговічний режим Франко створив Долину Полеглих, він визнав право обмеженого доступу до цього понурого некрополю тільки за тими, хто, на його думку, загинув у світовій боротьбі з більшовизмом і атеїзмом. Проте на державних маргінесах вже визрівала "пам'ять” про “іспанську" громадянську війну. Тільки після смерті підступного тирана й наступного на диво плинного переходу до буржуазної демократії - в якому вона відіграла вирішальну роль - ця “пам'ять" стала офіціиною. Подібним же чином колосальну класову битву, що лютувала між 1918 і 1920 роками на просторах від Паміру до Вісли, поступово почали пам'ятати/забувати в радянських фільмах і художній літературі, як "нашу" громадянську війну, тоді як Радянська держава в цілому дотримувалась марксистської інтерпретації цієї боротьби.

В цьому відношенні особливо показовими $є$ креольські націоналізми Америк. Адже, з одного боку американські держави впродовж кількох десятиріч були слабкими, фактично децентралізованими й доволі стриманими у своіх освітніх амбіціях. 3 другого боку, американські суспільства, в яких “білі" поселенці протиставлялися "чорним" рабам і напіввинищеним “тубільцям", були внутрішньо розколотими незрівнянно серйозніше, ніж у Європі. Проте уявлювання братерства, без якого не могла б народитися розрада братовбивства, з'являється напрочуд рано й користується несподівано непідробною популярністю. Сполучені Штати Америки є досконалим прикладом цього парадоксу. 
1840 року, в самому розпалі брутальної восьмирічної війни з Семинолами у Флориді (і в той час, коли Мішле викликав свого Едіпа), Джеймс Фенімор Купер опублікував "Слідопита", четверту книгу з його п'ятитомних, неймовірно популярних "Повістей Шкіряної Панчохи". В центрі цього твору (як і всіх, крім першої, книг із цієї серіі) є те, шо Леслі Фідлер назвав "суворою, майже невисловленою, проте безсумнівною любов’ю”, що пов'язує “білого” мешканця лісів Нетті Бамппо й величного вождя племені Делаварів Чингачгука (“Чикаго”!) тимства $€$ не смертоносні 1830 -ті, а останні забуті/згадані роки британського імперського правління. Обидва чоловіки постають "американцями", що борються за виживання - 3 французами, іхніми "місцевими" спільниками ("диявольськими Мінгами”) й підступними агентами Георга 111.

Коли в 1851 році Герман Мелвілл зобразив Ішмаїла та Квіквега разом у ліжку в затишному заїжджому дворі Споутер Інн ("і ось там, під час медового місяця наших сердець, лежали Квіквег і я"), він сардонічно американізував гордого полінезійського дикуна наступним чином ${ }^{33}$ :

...безумовно, що з точки зору френології його голова була надзвичайною. Може, це й смішно, але мені вона нагадувала голову Джорджа Вашингтона, яку ми звично бачимо на його славетних бюстах. Вона мала подібне спадисте чоло, а брови теж

\footnotetext{
${ }^{32}$ Див.: Leslie Fiedler. Love and Death in the American Novel, p. 192. Фідлер інтерпретував ці відносини психологічно й антиісторично, як приклад невміння американської художньої літератури мати справу з дорослою гетеросексуальною любов'ю та її одержимості смертю, кровозмішанням й невинним гомоеротизмом. Тут, я підозрюю, задіяний не стільки національний еротизм, скільки еротизований націоналізм. Зв'язки між чоловіками в протестантському суспільстві, яке від самого початку суворо забороняло змішані шлюби, були аналогічні "священним коханням" між чоловіками й жінками в націоналістичній художній літературі Латинської Америки, де католицтво не ставило перепон зростанню численного метиського населення. (Цікаво, шо англійська мова запозичила "mestizo" з іспанської.)

${ }^{33}$ Herman Melville. Moby Dick, p. 71.3 якою, мабуть, насолодою смакував автор свою останню уїдливу фразу!
} 
випиналися допереду, немов два довгих пасма, вкритих густим лісом. Квіквег був Джорджем Вашингтоном в образі канібала.

Лише 1881 року, багато пізніше після "громадянської війни" й Маніфесту Лінкольна про звільнення рабів, Марк Твен створив перший незабутній образ чорного й білого американських “братів”: Джима й Гека, що спільно подорожують широкою Міссісіпі ${ }^{34}$. Але тлом повісті $є$ згаданий/забутий довоєнний час, коли чорні ще залишалися рабами.

Ці разючі братерські уявлювання XIX ст., що "природньо" виникали в суспільстві, яке роздирали найлютіші расові, класові й регіональні антагонізми, дуже чітко демонструють те, що націоналізм часів Мішле й Ренана представляв собою нову форму свідомості - свідомості, яка народилася тоді, коли в наці1 вже неможливо було бачити щось нове, на гребні хвилі розриву.

\section{Біографія націй}

Всі грунтовні зміни свідомості вже за самою своєю природою приводять до характерних амнезій. Саме 3 цього забуття й виникають, за певних історичних обставин, наративні виклади подій. Перейшовши через фізіологічні й емоційні зміни, що супроводжують статеве визрівання, ми вже не спроможні "пригадати" дитячу свідомість. Скільки тисяч днів, що проминули від раннього дитинства до зрілості, зникають без жодної згадки! Як дивно потребувати сторонньої допомоги для з'ясування того, що ось це оголене немовля на пожовклій фотографії, яке щасливо посміхається 3 ліжечка чи з килимка, є саме тобою. Фотографія, це симпатичне дитя доби механічного репродукування, $є$ лише найнезаперечнішим із величезної кількості сучасного нагромадження документальних свідчень (свідоцтв про народження, щоденників, шкільних звітів, листів, медичних карток і такого

\footnotetext{
${ }^{34}$ Цікаво зазначити, що публікація "Геклберрі Фінна" лише на кілька місяців передувала Ренановому воскрешенню із забуття "la SaintBarthelemy".
} 
іншого), які фіксують певну очевидну безперервність і водночас підтверджують її зникнення з нашої пам'яті. 3 оцього відчуження й виникає концепція особистісності, $і$ дентичнос$m i$ (так, ти й це голе немовля $є$ ідентичними), яка через неможливість ії “запам'ятати” повинна бути розказаною. Всупереч твердженням біології про повну заміну всіх клітин людського тіла протягом семи років, наративні автобіографії й життєписи рік за роком переповнюють ринки друкарського капіталізму.

Ці наративи, як і романи й газети, розглянуті в II розділі, вміщено в однорідному порожньому часі. Відповідно, вони розміщені в історичних рамках і на соціологічному тлі. Ось чому стільки автобіографій розпочинаються 3 опису життя батьків і прабатьків, стосовно якого автобіографу доступні лише випадкові, письмові свідчення; й чому біограф намагається зафіксувати календарні, A.D. дати двох подій, які ніколи не підвладні пам'яті самих суб'єктів життєписів: народження й смерті. Ніщо так чітко не виявляє модерність подібного наративу, як початок Євангелії від Матвія. Адже євангеліст пропонує нам строгий список тридцяти чоловіків, що послідовно зачинали один одного, від патріарха Авраама до Ісуса Христа. (Лише одного разу згадано жінку, й не тому, що вона продовжувала рід, а тому, що походила з неєврейського племені моабитів.) Не наведено жодної дати з життя попередників Ісуса, вже й не кажучи про соціологічні, культурні, фізіологічні чи політичні відомості про них. Такий наративний стиль (який також віддзеркалював розрив-уВифлеємі, що став пам'яттю) видавався цілком обгрунтованим святому генеалогу, тому що він сприймав Христа не історичною "особистістю”, а істинним Сином Божим.

Як із сучасними людьми, так само і з націями. Усвідомлення включенності в секулярний, серійний час з усіма припушеннями його безперервності, але із "забуттям" досвіду цієї безперервності - продуктом розривів кінця XVIII ст. породжує потребу наративного викладу “ідентичності". Це вже завдання для магістратури Мішле. Між наративами особи й нації проте існує суттєва різниця. У світській історії "особи" існує початок і кінець. Вона народжується батьків- 


\section{УЯВЛЕНІ СПІЛЬНІОТИ}

ськими генами і соціальними обставинами для короткої появи на історичній арені, де грає свою роль до самої смерті. Після цього не залишається нічого, крім примарного серпанку слави чи авторитету. (Уявімо, як дивно було б закінчити нині життєпис Гітлера словами про те, що 30 квітня 1945 року він відійшов просто до пекла.) Нації, однак, ніколи не мають чітко визначених народжень, а їхні загибелі, якщо такі й трапляються, ніколи не проходять природнім чином ${ }^{35}$. Тому, що для них не існує Творця, біографії націй не можуть бути написаними євангелічно, "з глибини часу”, за допомогою довгого родового ланцюга зачать. Єдиною альтернативою є спроба зазирнути "вглиб часу" - до Пекінської пралюдини, Яванської пралюдини, Короля Артура, куди тільки зможе досягти мерехтливе сяйво ліхтаря археології. Це зазирання, однак, позначене смертями, які, завдяки своєрідній інверсії традиційної генеалогії, беруть свій початок у сучасності. Друга світова війна зачинає Першу світову війну; Седан породжує Аустерліц; предком Варшавського повстання стає держава Ізраїль.

Проте ті смерті, що структурують життєпис нації, є специфічного роду. На жодній із 1,200 сторінок вражаючої праці Фернана Броделя "La Méditerranee et le Monde Méditerraneen a l'Epoque de Philippe II" немає згадок про "la Saint-Barthélemy", хоча це відбулось якраз посередині правління Філіппа II. Для Броделя смертями, що мають якесь значення, $€$ ті міріади анонімних епізодів, які, зібрані докупи і виведені середньою величиною секулярних коефіціентів смертності, дозволяють йому скласти графік повільної зміни умов життя для мільйонів анонімних людських істот, національність яких нікого не турбує.

Життєпис нації, однак, вихоплює з оцих нещадно нагромаджуваних цвинтарів Броделя, всупереч чинним нормам смертності, показові самовбивства, стражденні мучеництва, вбивства, екзекуції, війни й голокости. Але для наративного викладу всі ці насильницькі смерті повинні пам'ятатись/ забуватись як "наші власні".

\footnotetext{
${ }^{35}$ Для подібних апокаліпсисів зовсім недавно був створений неологізм "геноцид".
} 


\section{Бібліографія}

Alers, Henri J. Om een rode of groene Merdeka. Tien jaren biennenlandse politiek. Indonesie, 1943-53. Eindhoven: Vulkaan. 1956.

Ambler, John Steward. The French Army in Politics, 1945-1962. Columbus: Ohio State University Press. 1966.

Anderson, Benedict R. O'Gorman. Language and Power: Exploring Political Cultures in Indonesia. Ithaca: Cornell University Press. 1990.

"Studies of the Thai State: The State of Thai Studies". In Eliezer B. Ayal, ed. The State of Thai Studies: Analyses of Knowoledge, Approaches, and Prospects in Anthropology, Art History, Economics, History and Political Science. Athens, Ohio: Ohio University, Center for International Studies, Southeast Asia Progran. 1979, pp. 193-247.

Auerbach, Erich. Mimesis. The Representation of Reality in Western Literature. Trans. Willard Trask. Garden City, N.Y.: Doubleday Anchor. 1957.

Baltazar [Balagtas], Francisco. Florante at Laura. Manila: Florentino. 1973. Based on the original Ramirez and Giraudier imprint of 1861.

Barnett, Anthony. "Inter-Communist Conflicts and Vietnam". Bulletin of Concerned Asian Scholars, 11:4 (October-December 1979). pp. 2-9. (Reprinted from Marxism Today, August 1979).

Barthes, Roland. Michelet parlui-méme. Bourges: Editions du Seuil. 1954. 


\section{УЯВЛЕНІ СПІЛЬНОТИ}

Battye, Noel A. "The Military, Governınent and Society in Siam, 18681910. Politics and Military Reform in the Reign of King Chulalongkorn". PhD. Thesis. Cornell University. 1974.

Bauer, Otto. Die Nationalitätenfrage und die Sozialdemocratie (1907), in his Werkausgabe. Vienna: Europaverlag. 1975. Vol. I, pp. 49-602.

Benda, Harry J. The Crescent and the Rising, Sun: Indonesian Islam under the Japanese Occupation. The Hague and Bandung: van Hoeve. 1958.

Benda, Harry J. and John A. Larkin, eds. The World of Southeast Asia: Selected Historical Readings. New York: Harper and Row. 1967.

Benjamin, Walter. Illuminations. London: Fontana. 1973.

Bloch, Marc. Feudal Society. Trans. I.A. Manyon. Chicago: University of Chicago Press. 1961. 2 vols.

Les Rois Thaumaturges. Strasbourg: Librairie Istra. 1924.

Boxer, Charles R. The Portuguese Seaborne Empire, 1415-1825. New York: Knopf: 1969.

Braudel, Fernand. La Mediterranee et le Monde Mediterranèen à l'Epoque de Philippe II. Paris: Armand Colin. 1966.

Browne, Thomas. Hydriotaphia, Urne-Buriall, or A Discourse of the Sepulchrall Urnes lately found in Norfolk. London: Noel Douglas Replicas. 1927.

Cambodge. Ministere du Plan et Institut National de la Statistique et des Recherches Économiques. Resultats Finals du Recensement General de la Population, 1962. Phnom Penh. 1966.

Chamber-Loir, Henri. "Mas Marco Kartodikromo (c. 1890-1932) ou L'Education Politique". In Pierre-Bernard Lafont and Denys Lombard, eds. Litteratures contemporaines de l'asie du sud-est. Paris: L'Asiatheque. 1974. pp. 203-214.

Cooper, James Fenimore. The Pathfinder. New York: Signet Classics. 1961.

Craig, Albert M. Chōshu in the Meiji Restoration. Cambridge, Mass.: Harvard University Press. 1967.

Craig, Gordon A. The Politics of the Prussian Army, 1640-1945. New York and Oxford: Oxford University Press. 1956.

Debray, Regis. "Marxism and the National Question". New Left Review, 105 (September-October 1977). pp. 25-41.

Defoe, Daniel. Selected Poetry and Prose of Daniel Defoe, ed. Michael F. Shugrue. New York: Holt, Rinehart and Winston. 1968.

Djilas, Milovan. Tito, the Inside Story. Trans. Vasilije Kojac and Richard Hayes. London: Weidenfeld and Nicholson. 1980. 
Eistenstein, Elizabeth L. "Some Conjectures about the Impact of Printing on Western Society and Thouglst: A Preliminary Report". Journal of Modern History, 40:1 (March 1968). pp.1-56.

Fall, Bernard B. Hell is a Very Small Place. The Siege of Dien Bien Phu. New York: Vintage. 1968.

Febvre, Lucien, and Henri-Jean Martin. The Coming of the Book. The Impact of Printing, 1450-1800. London: New Left Books. 1976. [Translation of L'Apparition du Livre. Paris: Albin Michel. 1958]

Fiedler, Leslie. Love and Death in the American Novel. New York: Stein and Day. 1966.

Fields, Rona M. The Portuguese Revolution and the Armed Forces Movement. New York, Washington and London: Praeger. 1975.

Franco, Jean. An Introduction to Spanish-American Literature. Cambridge: Cambridge University Press. 1969.

Gellner, Ernest. Thought and Change. London: Weidenfeld and Nicholson. 1964.

Gilmore, Robert L. Caudillism and Militarism in Venezuela, 1810-1919. Athens, Ohio: Ohio University Press. 1964.

Greene, Stephen. "Thai Government and Administration in the Reign of Rama VI (1910-1925)." Ph.D. thesis. University of London. 1971.

Groslier, Bernard Philippe. Indochina. Cleveland and New York: The World Publishing Company. 1966.

Heder, Stephen P. "The Kampuchean-Vietnamese Conflict." In David W.P. Elliott, ed. The Third Indochina Conflict. Boulder: Westview Press. 1981. pp. 21-67. (Reprinted from Institute of Southeast Asian Studies, ed. Southeast Asian Affairs. [London: Heinemann Educational Books. 1979]).

Higham, Charles. The Archaeology of Maintand Southeast Asia. New York and Cambridge: Cambridge University Press. 1989.

Hirschman, Charles. "The Making of Race in Colonial Malaya: Political Economy and Racial Ideology," Sociological Forum, 1:2 (Spring 1986). pp. 330-362.

"The Meaning and Measurement of Ethnicity in Malaysia:

An Analysis of Census Classifications". Joumal of Asian Studies, 46:3 (August 1987), pp. 555-582.

Hobsbawm, Eric. "Some Reflections on "The Break-up of Britain." New Left Review, 105 (September-October 1977), pp.3-24.

The Age of Revolution, 1789-1848. New York: Mentor. 1964.

Hodgson, Marshall G. The Venture of Islam. Chicago: Chicago University Press. 1974. 3 vols. 


\section{УЯВЛЕНІ СПІЛЬНОТИ}

Hoffman, John. "A Foreign Investment: Indies Malay to 1901". Indonesia, 27 (April 1979), pp. 65-92.

Hughes, Christopher. Swentzerland. New York: Praeger. 1975.

Ieu Koeus. Pheasa Khmer. La Langue Cambodgienne (Un Essai d'etude raisonne). Phnom Penh: n.p. 1964.

Ignotus, Paul. Hungary. New York and Washington, D.C.: Praeger. 1972.

Ileto, Reynaldo Clemena. Pasyon and Revolution: Popular Movements in the Philippines, 1840-1910. Manila: Ateneo Press. 1979.

Jaszi, Oscar. The Dissolution of the Habsburg Monarchy. Chicago: University of Chicago press. 1929.

Joaquin, Nick. A Question of Heroes. Manila: Ayala Museum. 1977.

Kahin, George McTurnan. Nationalism and Revolution in Indonesia. Ithaca: Cornell University Press. 1952.

Katzenstein, Peter J. Disjoined Partners. Austria and Germany since 1815. Berkeley and Los Angeles: University of California Press. 1976.

Kedourie, Elie, ed. and intro. Nationalism in Asia and Africa. New York: Meridian. 1970.

Kelly, Gail Paradise. "Franco-Vietnamese Schools, 1918 to 1938". Ph.D. thesis. University of Wisconsin. 1975.

Kemilainen, Aira. Nationalism: Problems Concerning the Word, the Concept and Classification. Jyvaskyla: Kustantajat. 1964.

Kempers, A.J. Bernet. Ancient Indonesian Art. Amsterdam: van der Peet. 1959.

Kirk-Greene, Anthony H.M. Crisis and Conflict in Nigeria: A Documentary Source Book. London: Oxford University Press. 1971.

Kohn, Hans. The Age of Nationalism. New York: Harper. 1962.

Krom, N.J. Inleiding tot de Hindoe-Javaansche Kunst. Second revised edition. The Hague: Nijhoff. 1923.

Kumar, Ann. "Diponegoro (1778?-1855)." Indonesia, 13 (April 1972). pp. $69-118$.

Landes, David S. Revolution in Time: Clocks and the Making of the Modern World. Cambridge, Mass.: Harvard University Press. 1983.

Leemans, C. Boro-Boudour. Leiden: Brill. 1874.

Luckham, Robin. The Nigerian Military: A Sociological Analysis of Authority and Revolt, 1960-67. Cambridge: Cambridge University Press. 1971.

Lumbera, Bienvenido L. Tagalog Poetry 1570-1898. Tradition and Influences in its Development. Quezon City: Ateneo de Manila Press. 1986. 
Lyautey, Louis-Hubert-Gonzalve. Lettres du Tonkin et de Madagascar (1894-1899). Paris: Librairie Armand Colin. 1946.

Lynch, Jolın. The Spanish-American Revolutions, 1808-1826. New York: Norton. 1973.

Mabry, Bevars D. The Development of Labor.Institutions in Thailand. Ithaca: Cornell University, Southeast Asia Program, Data Paper No. 112. 1979.

MacArthur, Douglas. A Soldier Speaks. Public Papers and Speeches of General of the Army Douglas MacArthur. New York: Praeger. 1965.

McLuhan, Marshall. The Gutenberg Galaxy: The Makng of Typographic Man. Toronto: University of Toronto Press. 1962.

Maki, John M. Japanese Militarism, Its Cause and Cure. New York: Knopf. 1945.

Marr, David G. Vietnamese Tradition on Trial, 1920-1945. Berkeley and Los Angeles: University of California Press. 1981.

Maruyama Masao. Thought and Behaviour in Modern Japanese Politics. London and Oxford: Oxford University Press. 1963.

Marx, Karl and Friedrich Engels. The Communist Manifesto. In Selected Works. Moscow: Foreign Languages Publishing House. 1958. vol. I.

Masur, Gerhard. Simón Bolivar. Albuquerque: University of New Mexico Press. 1948.

Melville, Herman. Moby Dick. London and Toronto: Cassell. 1930.

Michelet, Jules. "Histoire du XIXe Siecle". In Oeuvres Completes, ed. Paul Viallaneix. Paris: Flammarion. 1982. Vol. XXI.

Montesquieu, Henri de. Persian Letters. Trans. C.J. Betts. Harmondsworth: Penguin. 1973.

Moore, Jr., Barrington. Social Origins of Dictatorship and Democracy. Lord and Peasant in the Making of the Modern World. Boston: Beacon Press. 1966.

Morgan, Edward S. "The Heart of Jefferson". New York Review of Books. August 17, 1978.

Morgenthau, Ruth Schachter. Political Parties in French-Speaking West Africa. Oxford: Clarendon Press. 1964.

Moumouni, Abdou. L'Education en Afrique. Paris: Maspero. 1964.

Muir, Richard. Modem Political Geography. New York: Macmillan. 1975.

Musil, Robert. The Man Without Qualities. Trans. Eithne Wilkins and Ennst Kaiser. New York: Howard-McCann. 1953. vol. I.

Nairn, Tom. The Break-up of Britain. London: New Left Books. 1977. 
"The Modern Janus". New Left Review, 94 (November-December 1975). pp. 3-29. Reprinted as Chapter 9 in The Break-up of Britain.

"Nijs, E. Breton de". Tempo Doeloe. Amsterdam: Querido. 1973.

Norman, E. Herbert. Soldier and Peasant in Japan. The Origins of Conscription. New York: Institute of Pacific Relations. 1943.

Orwell, George. The Oreell Reader. New York: Harcourt-BraceJovanovich. 1956.

Osborne, Robin. Indonesia's Secret War, The Guerrilla Struggle in Irian Jaya. Sydney: Allen and Unwin. 1985.

Pal, Bipin Chandra. Memories of My Life and Times. Calcutta: Bipin Chandra Pal Institute. 1973.

"3349" [pseudonym for Phetsarath Ratanavongsa]. Iron Man of Laos: Prince Phetsarath Ratanavongsa. Trans. John B. Murdoch. Ed. David K. Wyatt. Ithaca: Cornell University, Southeast Asia Program, Data Paper No. 110. 1978.

Polo, Marco. The Travels of Marco Polo. Trans. and ed. William Marsden. London and New York: Everyman's Library. 1946.

Pramoedya Ananta Toer. Bumi Manusia. Jakarta: Hasta Mitra. 1980. Rumah Kaca. Jakarta: Hasta Mitra. 1988.

Tjerita dari Blora. Jakarta: Balai Pustaka. 1952.

Reid, Anthony J.S. The Indonesian National Revolution, 1945-50. Hawthorn, Victoria: Longman. 1974.

Renan, Ernest. “Qu'est-ce qu'une nation?”. In Oeuvres Completes. Paris: Calmann-Levy. 1947-61, vol. I, pp. 887-906.

Rizal, Jose. Noli Me Tangere. Manila: Instituto Nacional de Historia. 1978.

The Lost Eden. Noli Me Tangere. Trans. León Ma. Guerrero. Bloomington: Indiana University Press. 1961.

Roff, William R. The Origins of Malay Nationalism. New Haven and London: Yale University Press. 1967.

Said, Edward. Orientalism. New York: Pantheon. 1978.

Scherer, Savitri. "Harmony and Dissonance. Early Nationalist Thought in Java". M.A. thesis. Cornell University. 1975.

Schwartz, Stuart B. "The Formation of a Colonial Identity in Brazil." In Nicholas Canny and Anthony Pagden, eds. Colonial Identity in the Atlantic World, 1500-1800. Princeton: Princeton University Press, 1987, pp. 15-50.

Scott, William Henry. Cracks in the Parchment Curtain. Manila: New Day. 1982. 


\section{БІБЛІОГРАФІЯ}

Seton-Watson, Hugh. Nations and States. An Enquiry into the Origins of Nations and the Politics of Nationalism. Boulder, Colo.: Westview Press. 1977.

Shiraishi, Takashi. An Age in Motion: Popular Radicalism in Java, 19121926. Ithaca: Cornell Universitv Press. 1990.

Sitorus, Lintong Mulia. Sedjarah Pergerakan Kebangsaan Indonesia. Jakarta: Pustaka Rakjat. 1951.

Skinner, G. William. Chinese Society in Thailand. Ithaca: Cornell University Press. 1957.

Smith, Donald Eugene. India as a Secular State. Princeton: Princeton University Press. 1963.

Spear, Percival. India, Pakistan and the West. London, New York and Toronto: Oxford University Press. 1949.

Steinberg, S.H. Five Hundred Years og Printing. Rev. ed. Harmondsworth: Penguin. 1966.

Storry, Richard. The Double Patriots. A Study of Japanese Nationalism. London: Chatto and Windus. 1957.

Strong, Charles Frederick. Modern Political Constitutions. 8th Rev. ed. London: Sedgwick and Jackson. 1972.

Summers, Laura. "In Matters of War and Socialism, Anthony Barnett would Shame and Honour Kampuchea Too Much". Bulletin of Concerned Asian Scholars, 11:4 (October-December 1979), pp. $10-18$.

Taylor, Robert H. The State in Burma. London: C. Hurst \& Co. 1987.

Tickell, Paul. Three Early Indonesian Short Stories by Mas Marco Kartodikromo (c. 1890-1932). Melbourne: Monash University, Centre of Southeast Asian Studies, Working Paper No. 23. 1981.

Timpanaro, Sebastiano. On Materialism. London: New Left Books. 1975.

The Freudian Slip. London: New Left Books. 1976.

Thongchai Winichakul. "Siam Mapped: A History of the Geo-Body of Siam". Ph.D. thesis. University of Sydney. 1988.

Toye, IIugh. Laos: Buffer State or Battleground. London: Oxford University Press. 1968.

Turner, Victor. Dramas, Fields and Metaphors. Symbolic Action in Human Society. Ithaca: Cornell University Press. 1974.

The Forest of Symbols. Aspects of Ndembu Ritual. Ithaca: Cornell University Press. 1967.

Vagts, Alfred. A History of Militarism, Civilian and Military. Rev. ed. New York: The Free Press. 1959. 


\section{УЯВЛЕНІ СПІЛЬНОТИ}

Vandenbosch, Amry. The Dutch East Indies: Its Government, Problems and Politics. Berkeley and Los Angeles: University of California Press. 1944.

Vella, Walter F. Chaiyo! King Vajiravudh and the Development of Thai Nationalism. Honolulu: University of Hawaii Press. 1978.

Veyra, Jaime cle. El 'Ültimo Adiós' de Rizal: estudio crítico-exposivo. Manila: Bureau of Printing. 1946.

White, Hayden. Metahistory: The Historical Imagination in NineteenthCentury Europe. Baltimore: The Johns Hopkins University Press. 1973.

Wickberg, Edgar. The Chinese in Philippine Life, 1850-1898. New Haven: Yale University Press. 1965.

Williams, Raymond. "Timpanaro's Materialist Challenge". Nere Left Reviere, 109 (May-June 1978), pp. 3-17.

Wills, Gary. Inventing America: Jefferson's Declaration of Independence. New York: Doubleday. 1978.

Wolfe, Charles. The Poems of Charles Wolfe. London: Bullen. 1903.

Wolters, O.W. The Fall of Srivijay in Malay History. Ithaca: Cornell University Press. 1970.

Woodside, Alexander B. Vietnam and the Chinese Model. A Comparative Study of Vietnamese and Chinese Government in the First Half of the Nineteenth Century. Cambridge, Mass.: Harvard University Press. 1971.

Yabes, Leopoldo Y. "The Modern Literature of the Philippines". In Pierre-Bernard Lafont and Denys Lombard, eds. Litteratures contemporaines de l'asie du sud-est. Paris: L'Asiathéque. 1974, pp. 287-302.

Zasloff, Joseph J. The Pathet Lao: Leadership and Organization. Lexington, Mass.: Lexington Books. 1973. 


\section{Покажчик}

Aаргаy 170

Аасен, Івар Андреас 99, 100

Абіджан 163

Абубакар Тафава Балева 151

Августин, св. 41

Авраам 251

Австралія 121, 127, 167

Австрія 37, 101, 136, 138

Австро-Угорщина 103, 110, 126, 127

Аддісон, Джозеф 39

Адлер, Віктор 136

Адріян IV див. Брейкспір, Нікола

Айзенштайн Елізабет 63

Акапулько 75

Аккра 145, 156

Аладін 47

Албанія 18, 46-48

Алжир 141, 187

Алжир, м. 190

Алквін 116

Амстердам 153, 207

Ангкор 197, 199, 221, 224
Англія 15, 37, 53, 61, 62, 73, 78,

$94,115,116,120,129,135$,

$171,184,247$

Ангола 149, 236

Андалузія 83

Андерсон, Перрі 9

Андраші, Дьюла 134

Анна (Стюарт) 39

Аннам 157, 158, 162, 196

Антверпен 53, 93

Ап, Арнольд 221

Аравія 118

Аргентина 30, 76, 81, 88

Армстронг, Джон Александр 12

Артур 28, 252

Аскілт 44

Ататюрк Кемаль $\partial и в$. Кемаль Ататюрк

Ауербах, Ерix 9, 41, 92, 93

Аустерліц 252

Аушвіц 38

Афганістан 17

Афіни 47

Африфа, Аквасі А. 151 


\section{УЯВЛЕНІ СПЈЛЫНОТИ}

Баварія 110, 165

Баден 136

Байон 226

Балагтас (Балтазар), Франсиско 46,47

Балкани 98

Бамппо, Нетті 249

Бангкок 129, 157, 164, 214

Бандунг 153, 159

Барток, Бела 100

Батавія (Джакарта) 128, 129, $147,149,152,153,159,207$, $211,219,221,222$

Баттамбанг 159, 163, 222

Батті, Ноел 128

Бауер, Отто 13, 138, 139

Бах, Александр 133

Беда 116

Бекон, Френсис 58, 93

Беллерд, Д.А. 9

Бельгія 53, 101, 149

Бенарес 76

Бенгалія 94, 118

Бенджамін, Волтер 9, 10, 42, 57, 200

Бентам, Джеремі 228

Берег Слонової Кості 155

Берлін 112, 123

Бернадотти (династія) 138

Бернетт, Ентоні 9, 147, 225

Бессені, Дьордь 98

Бінондо 45, 47

Бірма 120, 128, 188, 214, 222224, 229

Блок, Марк 32, 35, 41, 62

Блуа 163

Блюхер, Гепгард Лейберехт фон 123

Боадіцея 28

Бовен Дігул 49

Богемія $37,53,97,105,241$

Богота 87, 118, 184

Боксер, Чарлз Р. 84
Болгарія 105

Болівар, Симон 71, 72, 76, 80, 81, 106

Болівія 76

Боніфаціо, Андрес 179

Бордо 155, 164

Борнео 206, 226, 235

Боробудур 221, 222, 227, 229

Бостон 88

Бота, Пітер 187

Бразилія 13, 30, 68, 69, 74, 84, 167,236

Браун, Томас 184

Брегенц 38

Брежнєв, Л. 187

Брейкспір, Нікола (Адріан IV) 32

Брейлі, Джон 12

Британія 39, 100, 103, 106, 193 , 194, 204, 239

Британія див. Сполучене Королівство; Англія

Британська імперія 109, 119, $127,149,167,174$

Британські острови 36 див. Англія

Брізен 38

Бродель, Фернан 252

Броз, Йосиф (Тіто) 199

Будапешт 98

Будда (Гаутама) 227, 239

Буенос-Айрес 75, 87

Буковина 37

Бурбони (династія) 124, 130, 187,233

Бургундія 40

Буркгардт, Якоб 243

Б’яфра 151

\section{Вавилон 192}

Вайт, Гейден 243, 244

Валіньяно, Александр 83, 84

Валліс 170 
ПОКАЖЧИК

Ван Ерп, Теодор 222

Ван Моок, Губертус 165

Ватикан 60

Вачіравут (Рама VI) 39, 129, 130

Вашингтон, Джордж 249, 250

Вашингтон, округ Колумбія 112

Вебер, Макс 22

Вебстер, Ноа 242

Велика Колумбія 72, 76, 89

Великий Іріан див. Нова Гвінея

Веллінгтон, Артур Велслі, герцог 236

Велс, Едвін 195

Вен Дайк, Дж. В. 214

Венесуела 70-72, 74-76, 81, 88 , $89,233,237$

Веспуччі, Амеріго 93

Вессекс 43

В'єнтньян 159, 160, 163

В'етнам 17, 18, 158, 161, 164, 165, 193, 195-200

Вифлеєм 239, 251

Відень 11, 96, 132-135

Війон, Франсуа 66

Вікліф, Джон 62

Віко, Джованні Баттіста 94

Вікторія (Саксе-Кобург-Гота) 115,117

Вілс, Гері 115

Вільгельм Завойовник 37,116 , 139,247

Вільгельм I (Оранський) 223

Вільгельм II (Гогенцоллерн) 112

Вільгельміна (Оранська) 232

Вільсен, Франс Карел 222

Віндзорська династія 109

Віндіш 38

Вінь 159

Вісла 248

Віттельзбахи (династія) 110

Віттенберг 59

Воєводина 38
Вольтер (Франсуа Mapi Apye) 36,94

Вордсворт Вільям 238

Вудсайд, Александр 196

Гаara 147, 153, 218

Габсбург (місцевість) 38

Габсбурги (династія) 99, 103, 109$111,124,137,139,143,166$

Гаїті 72, 237

Галичина (Галіція) 37, 99

Гальєні, Жозеф Сімон 190

Гана (Золотий Берег) 120, 156, 167,189

Гановери (династія) 109, 111

Гаральд 248

Гарібальді, Джузеппе 112, 198

Гастінгс 248

Гатчісон, Френсіс 95

Гвастела (Гвастала) 38

Гверреро, Леон Марія 13, 45

Гвінея 155

Гегель, Георг Вільгельм Фрідріх 54,243

Гедер, Стівен 9, 163, 164

Гейз, Карлтон 4

Гектор 184

Геллнер, Ернест 12, 23, 38

Гельветична републіка див. Швейцарія

Генрісон, Роберт 116

Георг I (Гановер) 139

Георг III (Гановер) 249

Гердер, Йоганн Готфрід фон 84, 91

Геррін, Джудіт 25, 31

Гіень 62

Гінденбург, Пол фон 195

Гіршман, Чарлз 204, 205

Гітлер, Адольф 247, 252

Гіто 44

Гнейзенау, Август Нейтхарт фон 40, 113 


\section{УЯВЛЕНI СІІЛЬНОТИ}

Toa 84

Гобіно, Жозеф Артюр де 187

Гобс, Томас 22, 35

Гогенембс 38

Гогенцоллерни (династія) 110 , $111,123,137,143$

Голландія (Нідерланди) 15, 52, $61,101,123,147,149,154$, 165-167, 188, 204, 233

Голландська Східна Індія див. Індонезія

Гомер 47

Гонконг 120

Гope 155

Градіска 38

Греція 39, 110, 184

Гріг, Едвад 100

Грізонс 170

Гросльє, Бернар Філіпп 222

Грох, Мірослав 12

Гроцій, Гюго (Г'юх де Хрот) 125

Грузія (Імеретія) 34

Грюнвальд, Бела 131

Гуй Кантул 163

Гутенберг, Йоганн 52

Гюрз (Гориція) 38

Дакар 155, 163

Далмація 37

Дамронг Раджанупаб 214, 215

Данбар, Вільям 116

Данія 39

Дарвін, Чарлз Роберт 27

Дворжак, Антон 100

Дебре, Режі 28, 149, 186

Декарт, Рене 36

Десіма 122

Дефо, Деніел 10, 43

Джайяварман VII 199

Джакарта див. Батавія

Джефферсон, Томас 71, 115

Джидда 221
Джіа-лонг (Нгуєн Ань) 195, 196

Джогджакарта 153

Джонс, Вільям 94, 221

Джонсон, В.Г. 214

Джорджтаун 145

Джугашвілі (Сталін), Й. В. 199

Дідро, Дені 53

Дікенс, Чарлз 54

Діпонегоро 28

Добровський, Йозеф 97, 100

Драйден, Джон 94

Дублін 121

Дувес Деккер, Едуард 147

Думер, Пол 223

Еберт, Фрідріх 37

Единбург 116

Едо див. Токіо

Еквадор 72, 76, 89

Енколпій 44

Есторіл 140

Єгипет 105, 184

Ерусалим 37

Женева 60, 170

Жуан VI (Браганса) 236

Зальцбург 37

Замбія 167

Занзібар 235

Зара (Задар) 38

Західний Іріан див. Нова Гвінея

Зімбабве 52

Золотий Берег див. Гана

Зонненберг 38

Зулуський Архіпелаг 29

Іберія 207, 232

Іван IV (Грозний) 199

Ігнотус, Пол 98, 132, 133

Ізраїль 186, 252 


\section{ПОКАЖЧИК}

Ілія 184

Іллірія 37

Імеретія див. Грузія

Індія $115,117,118,120,121,128$, $129,140,146,167,168,205,222$

Індокитай $11,17,128,155-164$, $167,190,222$

Індонезія (Голландська Східна Індія) $27,28,141,146,150$, $151,155,165-167,188,200$, $206,207,211,212,218-221$, $223-225,227,229,233$

Інокентій III 246

Інтрамурос $\mathbf{4 5}$

Ірак 67

Іран 67, 112

Ірландія 62, 103, 117, 150

Ісаак 41

Іспанія $15,52,70,72,80,81,87$, $101,110,145,204,207$

Істрія 38

Iсус Христос 34, 40, 41, 239, 251

Італія 52,173

Ішмаїл 249

Йазі, Оскар 136, 138, 140

Йоанн (Плантагенет) 149

Иоанн Хреститель 49

Йо Кеус 163

Йоркшир 116

Йосиф II (Габсбург) 98, 110, 131

Кагосіма 123

Кадуна 151

Kaïp 212

Кайсон Фумвіган 159

Кале 155

Каліфорнія 88

Кальвін, Джон 61

Калькутта 221

Камбоджа (Кампучія) 17, 157, 161-164, 193-197, 199, 200
Кампучія дия. К:миющ):

Kaıı Ю-вей 158

Kana/a 88, 121

Канбалу 33

Канберра 121

Кансі 234

Каракас 72, 86, 184, 212

Карачі 14

Карвальо, де 74

Каринтія 37

Карл I (Стюарт) 39

Карл I (Стюарт) 39

Карл IX (Валуа) 246

Карл V (Габсбург) 184

Карлос III (Бурбон) 73

Картахена 75, 80

Картер, Джеймс Ерл 35

Картодікромо, Мас Марко 49, 51

Кастрі, де 189

Катагалуган 191

Каттаро 38

Кауффман, Анжеліка 169

Каценштейн, Пітер 9

Квансі 196

Квантун 196

Квебек 109

Квіквег 249, 250

Кейп Коуст 156

Кейптаун 121

Келлі, Гейл П. 158

Кемаль Ататюрк (Ататюрк Кемаль) 28, 67

Кеміляйнен, Айра 21

Кенігграц 133

Керзон, Джордж Натаніел 222

Київ 99

Китай (КНР, Серединна імперія) $18,61,65,93,125,129,157,158$, $193,197-200,234$

Кібург 17, 18

Кіото 124

Кіссінджер, Генрі 187 


\section{УЯВЛЕНІ СПІЛЬНОТИ}

Кіта Іккі 126

Кіто 71

Клаузевіц, Карл фон 40, 113, 190

КНР див. Китай

Кобург 38

Козінці, Ференц 98, 100

Коїмбра

Коломбо 145

Колонії Протоки 204, 210

Колумб, Христофор 238

Колумбія 76

Кон, Ганс 21

Конго, Бельгійське 140, 149

Конго, Французьке 190

Конрад, Джозеф 78

Констант, Бенджамін 169

Константинополь (Стамбул) 11, 100,105

Коперник 20

Кораес, Адамантіос 97, 104, 240

Корея 29, 125

Корнель, П'єр 60

Кортес, Ернан 244

Корунья 182

Котляревський, Іван 98

Котону 163

Кочин-Китай 157, 158, 161, 162, 165

Кошут, Лайош 132, 133, 135

Крайна 37

Краків 37

Куала Кангсар 98

Кубілай див. Кубла Хан

Кубла Хан (Кубілай) 33, 34

Купер, Джеймс Фенімор 249

Кюсю 124

Ламанш 36

Лаос 157, 159-162

Латтр де Тасіньї, Жан де189, 190

Лаузіц 38

Лаура 46
Лафонтен, Жан де 60

Левант 140

Лейден 153

Леопольд II (Габсбург) 98

Леопольд II (Саксе-Кобург) 78

Лізарді, Хосе Хоакін Фернандез де 48,49

Ліль 102

Ліма 80,85

Ліманс, Конрадус 222

Лінкольн, Авраам 250

Ліон 102

Лісабон 84

Ліхтенштейн 171

Лодомерія 37

Лок, Джон 115

Лон Нол 199, 227

Лондон 11, 38, 62, 63, 74, 79, 112, $117,119,121,155,156,207$, $232,234,236$

Лос-Анжелес 43

Лотарінгія 37

Лумб́ера, Б'енвенідо 47, 48

Луна, Антоніо 217

Любек 43

Людовик Наполеон (Бонапарт) 187, 223, 245

Людовик XIV (Бурбон) 93

Людовик XV (Бурбон) 39

Людовик XVI (Бурбон) 39

Лютер, Мартін 53, 59, 60

Лянг Ци-чао 158

Льоте, Луї-Юбер-Гонзалве 189, 190

Маврикій 112

Магвінданао 29

Магомет 34

Мадагаскар 190

Мадзіні, Джузеппе 144

Мадрид 11, 70-75, 80, 81, 83, 112 , 207,234 


\section{ПОКАЖЧИК}

Мазур, Герхард 80

Мазурські озера 195

Май Тхо 159

Макао 236

Маклюен, Маршалл 53

Макмагон, Марі Едме Патріс Моріс де 187

Маколей, Томас Бабінгтон 118$120,127,198$

Макондо 87

Мак'явеллі, Ніколо 67

Малайя (Малайзія) 120, 128, 129, $152,153,204,207,211,226$

Малаккська протока 152

Малі 52, 155

Маніла 45, 46, 153, 207, 208, 212

Мануель I (Авіз) 83

Манунціо, Альдо 54

Манчестер 121

Манчжури (династія) 234

Мао Цзедун 195, 199

Марія Луїза (Парма) 80

Марія Тереза (Габсбург) 98

Марк Твен (Семюел Клеменс) 250

Маркес, Габрієль Гарсія 87

Маркс, Карл 20, 22, 173, 243

Марло, Крістофер 93

Марокко 29

Марр, Девід 161, 167, 168, 197

Мартен, Анрі-Жан 35, 57, 63, 65, 85

Маруяма Масао 125

Маскат 235

Матвій, св. 251

Мафусаїл 184

Мейдзі 122, 123, 127, 154

Мекка 29, 76, 77, 211, 212

Меконг, р. 161, 163

Мексика 48, 49, 70, 73, 74, 80, 81, $87,93,238,244$

Мелвілл, Герман 249

Мелло, Мануель 80
Мендель 130

Мерауке 218

Мергвійська затока 208

Меттерніх, Клеменс Вензель Лотар фон 137

Мехіко 85, 87, 244

Мін (династія) 234

Мінданао 226

Miccicini, p. 207, 250

Міттеран, Франсуа 52

Мішле, Жюль 243, 244, 245, 249 , 250,251

Могольська імперія 235

Модена 38

Мозамбік 149, 167, 168, 236

Мойсей 34

Молуккські острови 221

Мольєр (Жан-Батист Поклен) 60

Монгкут (Рама IV) 212

Монте-Карло 140

Монтеск'є, Шарль Луї де 94

Мор, Томас 93

Моравія 38

Морелос і Павон, Хосе Марія 238

Мортінер, Рекс 9

Москва 11, 198, 212

Мочарі, Лайош 135

Мулерн, Френсіс 9

Мулмейн 188

Мур, Джон 182, 183

Мюр, Річард 213

Нагасакі 122

Нанкін 198

Наполеон (Бонапарт) 74, 80, 94, 106, 107, 122, 221, 223, 247

Нгуєн Ань див. Джіа-лонг

Невшатель 170

Нейрн, Том 9, 19, 22, 37, 55, 69, $105,115-117,177,185,193,194$

Нзеогву, Чукума 151

Нігерія 151 


\section{УЯВЛЕНІ СПІЛЬНОТИ}

Нідвальден 169

Нідерланди див. Голландія Німеччина 17, 52, 112, 128, 137, $149,173,186$

Нова Гвінея (Великий Іріан, Західний Іріан) 49, 153, 218220

Нова Гранада 72

Нова Зеландія 121

Норвегія 99

Нородом Сіанук 160, 199, 226, 227

Нортумбрія 116

Нью-Йорк 88, 182

Обвальден 169

Одеса 96

Олександр III (Романов) 114, 115

Омура Масуджіро 122

Оранська династія 109, 149

Осака 122,124

Османи (династія) 111, 143

Османська імперія 96, 97, 235

Оттава 121

Отто Фрейзінгенський 41,184

\section{Павло, св. 41}

Паган 221, 222, 229

Пакистан 169

Пал, Біпін Чандра 119-121, 150

Парагвай 29, 76, 89, 242

Париж 11, 34, 35, 54, 63, 96, 97, $112,131,163,212,238$

Парма 38

Паскаль, Блез 36

Педро I (Браганса) 74

Пекін 130, 195, 196, 234

Перікільо 48

Перікл 97

Перрі, Метью Келбрейт 121, 122

Перро, Шарль 92

Персія 67, 105

Перу 70-72, 88, 93, 238
Петефі, Шандор 133

Петіон, Александр 72

Петро, св. 34

Петроній Арбітер, Гай 44

Пехлеві, Мохаммед-Реза 112

Пехлеві, Реза 112

Пешт 131

Південна Африка 121

Південно-Молуккська республіка 165

Плаек Фібунсонгхрам 157

Плантен, Христоф 53

Платон 93

Пномпень 157, 161, 163, 164

Пол Пот 197, 227

Поло, Марко 33, 34

Польща 53

Помбаль 84

Понті, Вільям (Вільям МерлоПонті) 155, 156

Понтіанак 235

Поп, Александр 39

Портільо, Хосе Лопес 244

Португалія 15, 74, 83, 84, 143 , 149,204

Прамоедья Ананта Тоер 184, 228,232

Пріанган 153

Пруссія 40, 110, 123, 135, 137, 151,189

П'яченна 38

Рагуза 38

Рама IV див. Монгкут

Рама V див. Чулалонгкорн

Рама VI див. Вачіравут

Рангун 145, 149, 153

Ранке, Леопольд фон 243

Рафл3, Томас Стемфорд 221, 222

Ренан, Ернест 14, 22, 196, 245-

$$
\text { 247, 249, } 250
$$

Реннер, Карл 137 


\section{ПОКАЖЧИК}

Рим 76, 77, 153, 174

Ріо-де-Жанейро 236

Ріо де ла Плата 76, 87, 89

Рісаль, Хосе 13, 44-47, 49, 145, 178,179

Річардсон, Семюел 43

Родс, Александр де 158

Романови (династія) 109, $111-113,143$

Росія $39,96,100,101,125,126$, 135,192

Роуноук 238

Рофф, Вільям 119

Румунія 110

Руссо, Жан-Жак 84, 94, 158, 181

Р'яу 166

Сабанг 218

Саїд Саїд 235

Сайгон 159, 161-163, 222

Сакай, Марio 191

Саломея 49

Саммерс, Лора 9

Сан Мартін, Хосе де 72, 74, 80 ,

$87,106,107,182,198,238,240$

Санкт-Петербург 113, 115, 119

Сантос, Сантьяго де лос 45

Сантьяго 75

Caparoca 80

Сараєво 38

Сардауна з Сокото 151

Сарро, Альбер 159, 160

Сатор 38

Саудівська Аравія 128

Сацума 122

Свіфт, Джонатан 93

Семаранг 50

Сен Гален 170

Cена, p. 62, 131

Сенагал 155

Cent-Лyї 155

Сербія 38
Серединна імлерія див. Китай

Сетон-Вотсон, Хью 19, 95, 97 , 99, 112-114, 116, 140, 169

Сечені, Іштваи 131

Сибір 99, 127

Силезія 38

Сисмонді 169, 170

Сисоват Ютевонг 163

Сіам 15, 39, 72, 101, 127, 129, 130 , $140,157,173,204,211,212,214$, $217,222,223,229,234$

Сігел, Джім 9

Сіемреап 222

Сімоносекі 123

Сінасі, Ібрагім 100

Сінгапур 120, 128, 129, 153, 166, $207,221,226$

Сіторус, Лінтон Мулія 240

Сіфас, Касіган 222

Скотт, Вільям Генрі 206, 207

Словаччина 105

Словенія 37

Сметана, Бедржих 100

Сміт, Адам 21, 115

Сміт, Ентоні 12

Согомомбар-хан 34

Сокото 151

Сократ 97

Сон Нгок Тань 163

Сонн Веуннсай 163

Сполучене Королівство 19, 80 , $123,128,138,155,233$

Сполучені Штати Америки 15, $30,69,74,82,88,101,106$, $123,138,194,204,237,248$

СРCP 18, 19, 67, 138, 187, 197, 198

Стайн, Гертруда 22

Сталін див. Джугашвілі

Сталь-Олстен, Енн де 169, 170

Стамбул див. Константинополь

Стефан, св. 139

Стюарти (династія) 109 


\section{УЯ્રЛЕНІ СПІЛЬНОТИ}

Суварді Сурджанінграт (Кі Гаджар Деванторо) 147 148,149

Сукарно 28, 153, 219

Сулавесі 206

Суматра 152, 165, 218

Сун Ят-сен 158

Суракарта 153

Суфанувонг 159

Сухарто 152,200

Східний Тимор 152, 219, 236

Тагалог 191

Таїланд 67, 212

Таїті 190

Тайвань 125

Такаші, Шираїлі 9

Тамерлан 93

Танзанія 167

Танненберг 195

Тернер, Віктор 9, 76

Texac 88

Тешин 38

Тжіпто Мангоенкоесоемо 147

Тідоре 218

Тійон, Серж 155

Тікел, Пол 49

Тіроль 38

Тіса, Іштван 133, 137

Тіса, Кальман 133-135

Тічино 170

Тоер див. Прамоед'я Ананта Тоер

Токвіль, Алексіс де 22, 243

Токіо (Едо) 122-124

Токугава 121

Толкін, Джон Роналд Руел 28

Тонкін 157, 158,162, 189, 190

Тоскана 37

Тоя, Хью 162

Трансильванія 38

Tpiect 38

Трнава 98
Троцький (Бронштейн), Лев 198

Тупак Амару 71, 192

Туреччина 67

Туссен Лувертюр 71, 237

Тхонгчай Вінічакул 14, 212-215

Тюдори (династія) 109

Тьяго 45

Уваджіма 122

Уваров, Сергій 114, 118, 130, 144, 198

Угорщина 17, 37, 104, 107, 110, $111,127,131,134,136,138$, 140,173

Уельс 62

Унгар, Еста 9

Уругвай 76,89

Февр, Люсьєн 35, 57, 63, 65, 85

Фейдерб, Луї Леон Сезар 190

Феліпп II (Габсбург) 207, 252

Фельдкірх 38

Фермін де Варгас, Педро 30, 31 , $82,118,245$

Фетсарат Ратанавонгса 160

Фідлер, Леслі 249

Філадельфія 88, 237, 245

Філдінг, Генрі 43

Філіппіни 47, 113, 145, 149, 153, $179,206-208,218,229,233$

Фінляндія 99, 105

Флорант 46, 47

Флорида 207, 249

Форст, Отто 38

Форстер, Бальтазар 187

Франклін, Бенджамін 85, 115

Франко, Франсіско 248

Франсія, Хосе Гаспар Родрігес де 242

Франц II (Габсбург) 131, 137

Франц Йосиф (Габсбург) 38

Франц Фердинанд (Габсбург) 28 


\section{ПОКАЖЧИК}

Франциск I (Валуа-Орлеан) 6063

Франція 15, 23, 28, 39, 52, 60, 62, $96,100,101,103,106,107$, $110,129,136,156,160,161$, $163,173,186,188,190,194$, 197, 204, 221, 245

Фрідріх Великий (Гогенцоллерн) 39

Фрідріх Вільгельм III (Гогенцоллерн) 39

Фріулі 38

Фузелі, Анрі (Йоганн Гайнріх Фюсслі) 169

Фуко, Мішель 46, 222

Фуст, Йоганн 53

Хадрамаут 235

Ханой 157, 159, 162-164

Хань (династія) 196

Харрісон, Джон 214, 215, 232

Хатчісон 115

Хоакін, Нік 217

Хобсбоум, Ерік 12, 19, 23, 95, 96, $105,115,177,194$

Хомейні, Руголла 35

Хонсю 124, 127

Хорватія 37

Хорті, Міклош 136

Хоудлі, Мейсон 208

Хуa 157, 165

Хьюз, Крістофер 169, 170, 172, 173

Цейлон 233

Цицерон 59

Цторіх 124

Чамбас, Могамед 9, 156

Чан Кай-ші 198
Чail- ro 234

Чсгабі 112

Четтерджі, Партга 12

Чехословаччина 17

Чжоу Еньлай 194

Чин ІШи Гуан-ті 199

Чингачгук 249

Чілі 74, 81

Чосюо 122,123

Чулалонгкорн (Рама V) 39, $127,128,214$

ІІампольйон, Жан Франсуа 94

ІІІарнхорст, Герхард фон 40, 113

Швейцарія 53, 169-171, 173, 194

Швеція 39

Швіц 169

ІІІевченко, Тарас 99

IІекспір, Вільям 36

Шефер, Адольф 222

Шеффер, Пітер 53

Шомбер, Луар 51

- ІІІосслу-Лоба 160

Шотландія 37, 62, 116, 233

Шірі Ланка 29

Штайнберг, Зігфрід Генрі 65

IIIтирія 37

Югославія 18, 199

Юдея 184

Юм, Девід 115

Юн-ло 234

Юнгманн, Йозеф 97

Ява 28, 51, 206, 208, 214, 221

Яначек, Леош 100

Янцзи-к'ян, p. 208

Японія 29, 39, 93, 121-127, 141, 164,168

Ясі, Оскар 13, 38 
Наукове видання

Бенедикт Андерсон

\title{
Уявлені спільноти
}

\section{Міркування щодо походження \\ й поширення націоналізму}

\author{
Технічна редакція \\ майї IIритикіної
}

Комп'ютерна верстка

Олега Соханя

\author{
Підписано до друку 26.12.2000. \\ Формат 60х90/16. Гарнітура Петербург. \\ Папір офсетний № 1. Друк офсетний. \\ Фіз.-друк. арк. 17,0. Умови. фарбовідб. 17,5. Обл. вид. арк. 15,?4. \\ Зам. 1-60. \\ СП “Часопис «Критика»”. 01001 Київ-1, а/с 255. \\ Свідоцтво про реєстрацію КВ 2690 від 21.04.97.
}

Нагруковано в АТ «Книга». Київ-53, вул. Артема, 25 


\section{Benedict Anderson}

\section{Imagined Communities}

Reflections on the Origin and Spread of Nationalism 